\title{
Pembelajaran \\ Pencegahan Kebakaran dan Restorasi Gambut Berbasis Masyarakat
}

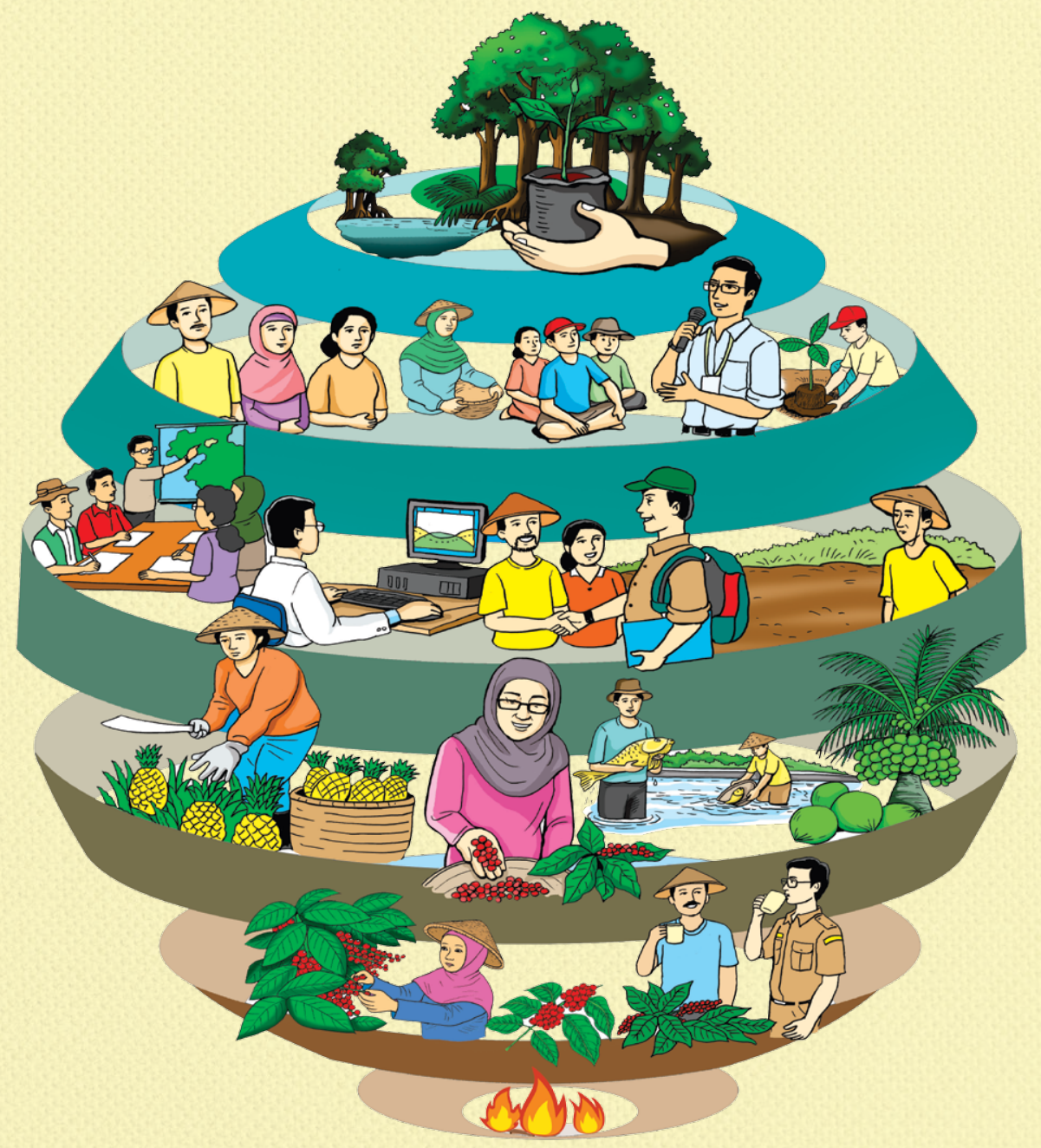

Editor:

Herry Purnomo dan Dyah Puspitaloka

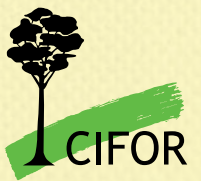





\title{
Pembelajaran \\ Pencegahan Kebakaran dan Restorasi Gambut Berbasis Masyarakat
}

\author{
Editor: \\ Herry Purnomo dan Dyah Puspitaloka
}

Editor Bahasa Indonesia:

Wiene Andriyana 
(C) 2020 Pusat Penelitian Kehutanan Internasional (CIFOR)

Hak cipta dilindungi oleh Undang-Undang

(c) (i) Materi dalam publikasi ini berlisensi di dalam Creative Commons Attribution 4.0 International (CC BY 4.0), http://creativecommons.org/licenses/by/4.0/

DOI: $10.17528 /$ cifor/007500

ISBN: 978-602-387-127-8

Purnomo H dan Puspitaloka D (ed). 2020. Pembelajaran Pencegahan Kebakaran dan

Restorasi Gambut Berbasis Masyarakat. Bogor, Indonesia: CIFOR.

Desain oleh Tim Publikasi, Digital dan Editorial, COE, CIFOR

Gambar ilustrasi oleh Komarudin

Foto bab: 1, 3, 4, 5, 6, 7, 8 dan 9 Aris Sanjaya/CIFOR, 2 M. Gunawan Wibisono/UGM

\author{
CIFOR \\ Jl. CIFOR, Situ Gede \\ Bogor Barat 16115 \\ Indonesia \\ $\mathrm{T}+62(251) 8622-622$ \\ $\mathrm{F}+62$ (251) 8622-100 \\ E cifor@cgiar.org
}

\title{
cifor.org/CBFPR
}

\section{Pusat Penelitian Kehutanan Internasional (CIFOR)}

CIFOR meningkatkan kesejahteraan manusia, kesetaraan dan integritas lingkungan dengan melakukan penelitian inovatif, mengembangkan kapasitas para mitra dan terlibat secara aktif dalam dialog dengan semua pemangku kepentingan untuk memberi masukan terhadap berbagai kebijakan dan praktik yang memengaruhi hutan dan masyarakat. CIFOR merupakan bagian dari Pusat Penelitian CGIAR, dan memimpin Program Penelitian CGIAR pada Hutan, Pohon dan Wanatani (FTA). Kantor pusat kami berada di Bogor, Indonesia, dengan kantor wilayah di Nairobi, Kenya; Yaounde, Kamerun; Lima, Peru dan Bonn, Jerman.

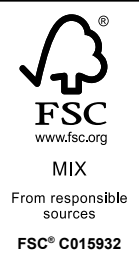




\section{Daftar Isi}

Kata Pengantar

iv

Ucapan Terima Kasih

viii

Ringkasan

ix

Daftar Penulis

xiii

Daftar Singkatan

$x v i$

1 Teori dan Pelaksanaan Riset Aksi Partisipatif untuk Pencegahan Kebakaran dan Restorasi Gambut Berbasis Masyarakat

Herry Purnomo, Dyah Puspitaloka, Heru Komarudin, Agus Andrianto, Beni Okarda, Imam Basuki, Pandam Prasetyo, Nurul Qomar, Ahmad Muhammad, Sigit Sutikno, Ashaluddin Jalil, Yesi, Haris Gunawan, Zulkardi, Rafi Merbamas, Tarsono dan Lukas Rumboko Wibowo

2 Perubahan Perilaku Pembakaran dan Pencegahan Kebakaran di Riau

Murni Po, Daniel Mendham, John Gardner, Eko Hardiyanto, M. Gunawan Wibisono dan Muhammad Mardhiansyah

3 Model Bisnis Berkelanjutan bagi Masyarakat untuk Pencegahan Kebakaran dan Restorasi di Lahan Gambut

Dyah Puspitaloka, Herry Purnomo, Ahmad Dermawan, Tuti Herawati, Nunung Parlinah dan Qori Pebrial Ilham

4 Pembangunan Sekat Kanal dan Sistem Pemantauan Tinggi Muka Air Tanah Imam Basuki, Beni Okarda, Sigit Sutikno dan Adhy Prayitno

5 Penyiapan Lahan Tanpa Bakar untuk Pencegahan Kebakaran Hutan dan Lahan

Nurul Qomar, Ahmad Muhammad, Qori Pebrial Ilham, Hari Priyadi Rusantoyo dan Lailan Syaufina

6 Penanaman di Lahan Gambut

Pandam Nugroho Prasetyo, Zulkardi, Rafi Merbamas, Herry Purnomo dan Dyah Puspitaloka

7 Penguatan Masyarakat Peduli Api: Pembelajaran dari Sebuah Riset Aksi Partisipatif 145 Agus Andrianto, Heru Komarudin, Dyah Puspitaloka, Rozi, Deden Djaenudin dan Aenunaim

8 Pengembangan Lembaga Kelompok Tani Hutan di Desa Dompas

Agus Andrianto, Dyah Puspitaloka, Pandam Nugroho Prasetyo, Heru Komarudin, Zulkardi dan Fitri Nurfatriani

9 Sistem Pemantauan Restorasi Gambut Berbasis Masyarakat atau Community-based Peatland Restoration Monitoring System (CO-PROMISE)

Beni Okarda, Herry Purnomo, Imam Basuki, Usman Muchlish, Shintia Arwida dan Himlal Baral 


\section{Kata Pengantar}

Kebakaran lahan dan hutan (karhutla) terus terjadi dan meningkat pada tahun 2019 dibandingkan tahun-tahun sebelumnya. Tragedi karhutla pada tahun 2015 seluas 2,6 juta ha dan telah menimbulkan kerugian ekonomi sebesar 16,1 miliar dolar AS membuat banyak pihak lebih sadar untuk melakukan aksi pencegahan terhadap karhutla secara sistematis dan masif. Karhutla membawa kerugian ekonomi, lingkungan, kesehatan, pendidikan dan transportasi yang besar pada masyarakat secara luas. Namun ada pihak-pihak yang diuntungkan secara ekonomi dengan karhutla karena mempermudah dan mempercepat pengolahan lahan untuk pertanian. Usaha-usaha transformasi masyarakat dan korporasi harus dilakukan secara rasional dengan memahami situasi di lapangan dan kebutuhan masyarakat akan penghidupan yang layak.

Kebakaran terjadi di lahan mineral dan gambut. Kebakaran di lahan gambut (peatlands) sulit dipadamkan dan menghasilkan emisi $\mathrm{CO}_{2}$ ekuivalen yang jauh lebih besar. Usahausaha budidaya pertanian di lahan gambut dangkal, yang diperbolehkan oleh regulasi, harus dicermati dan diarahkan pada pertanian yang ramah terhadap ekosistem lembab dan basah. Sedangkan gambut dalam dan kubah gambut seyogianya dijadikan kawasan konservasi, yang tentu tanpa meniadakan sumber-sumber penghasilan bagi masyarakat. Bahkan masyarakat harus menjadi aktor utama dalam restorasi dan konservasi gambut. Pendekatan manajemen lahan dan hutan berbasis aktor harus menjadi arah baru bagi pencegahan kebakaran dan restorasi gambut. Untuk berubah, masyarakat tidaklah cukup untuk dibagi pengetahuan, tetapi perlu mengalami secara langsung bagaimana mencegah kebakaran dan restorasi gambut dalam skala ekonomi yang sebenarnya. Kompleksitas masalah kebakaran dan restorasi gambut tidak membuat semua pengetahuan yang diperlukan tersedia dan sesuai. Gabungan dari kedua kebutuhan tersebut melahirkan perlunya riset aksi partisipatif (RAP).

CIFOR (Center for International Forestry Research) bekerja sama dengan Universitas Riau (UNRI), the Commonwealth Scientific and Industrial Research Organization (CSIRO) dan Universitas Gadjah Mada (UGM), dengan dukungan dana dari Temasek Foundation (TF) telah melakukan riset untuk memahami sebab-sebab kebakaran dan RAP untuk mencegah kebakaran dan restorasi gambut yang berbasis aktor, yang dalam hal ini adalah masyarakat. Program ini dikelola oleh Singapore Cooperation Enterprise (SCE). Riset dilakukan di Provinsi Riau, Indonesia. RAP, khususnya, dilakukan 
di Desa Dompas, Kecamatan Bukit Batu, Kabupaten Bengkalis. RAP dilakukan pada tahun 2018-2019 melalui kerja sama dengan Masyarakat Peduli Api (MPA), Pemerintah Desa Dompas, dan kelompok-kelompok masyarakat lainnya. Hasil dari riset ini disarikan dan dikemas dalam Buku Pembelajaran dari Pencegahan Kebakaran dan Restorasi Gambut Berbasis Masyarakat (pembelajaran 1-9) untuk dapat dipahami dengan lebih mudah. Hasil riset ini telah dipaparkan dalam lokakarya di Kabupaten Bengkalis untuk mendapatkan umpan balik di tingkat lokal pada tanggal 28-29 Agustus 2019 dan di Pekanbaru untuk mendapatkan masukan di tingkat nasional pada tanggal 24 Oktober 2019. Umpan balik dan masukan ini digabungkan dengan masukan dan kontribusi dari para praktisi dan akademisi yang terlibat dalam proses peninjauan yang berlangsung selama bulan November dan lokakarya peninjauan buku yang berlangsung pada tanggal 3 Desember 2019.

Buku pembelajaran ini lahir dari riset aksi partisipatif (RAP) yang kami lakukan. Tujuan RAP adalah mendukung perubahan perilaku masyarakat lokal secara bertahap dalam pembukaan lahan tanpa bakar. Lewat RAP, pengembangan pengetahuan dan perubahan tingkah laku akan terjadi pada saat yang hampir bersamaan. Dalam RAP, kami meneliti, memfasilitasi dan mengarusutamakan pengembangan lahan tanpa bakar. Kami mendampingi masyarakat lokal untuk memilih dan menerapkan alternatif pembukaan lahan tanpa bakar dan model bisnis berkelanjutan sebagai bagian dari upaya pencegahan kebakaran dan restorasi gambut, maupun sebagai proses belajar bersama (co-learning). Melalui metode RAP, kami melaksanakan rangkaian kegiatan, studi, dan diskusi melalui tahapan berulang dari: 'refleksi', 'perencanaan', 'aksi', dan 'pemantauan' secara bersama dengan mitra-mitra dan masyarakat lokal.

Kami memfasilitasi rangkaian diskusi dan kegiatan pada tujuh arena aksi di Desa Dompas, yang diidentifikasi dan dipilih bersama masyarakat secara partisipatif. Pada arena-arena aksi tersebut, masyarakat mengembangkan model bisnis berkelanjutan untuk pencegahan kebakaran dan restorasi gambut. Arena-arena aksi ini terletak di wilayah-wilayah yang mengandung gambut dengan karakteristik biofisik yang unik. Kami mengklasifikasikan arena-arena aksi ini ke dalam empat jenis pengelolaan lahan: lahan publik, pribadi, pengelolaan bersama (co-management), dan pekarangan. Kondisi biofisik, sosial, dan ekonomi pada setiap arena aksi dipelajari dengan seksama. Kami bekerja bersama untuk memahami dan merumuskan peran-peran dan tanggung jawab, mekanisme pembagian biaya-manfaat, serta merencanakan komoditas-komoditas yang akan dikembangkan, model bisnis, rekayasa lanskap, dan lain-lain. Rencana itu kemudian ditindaklanjuti dengan aksi-aksi bersama yang antara lain berupa penyekatan kanal untuk membasahi atau melembabkan gambut, penanaman pohon, budidaya ikan, pengembangan wanatani nanas, tumpang sari kopi liberika dan karet, pengembangan kelapa hibrida di pekarangan masyarakat, serta penguatan kelembagaan masyarakat dan kelompok tani. Pemantauan dilakukan terhadap indikator biofisik dan sosial ekonomi masyarakat. 
Buku pembelajaran ini dimaksudkan sebagai sarana untuk berbagi pengetahuan dan pengalaman dari riset dan RAP untuk memahami dan mencegah kebakaran dan restorasi gambut berbasis masyarakat. Buku ini dalam bentuknya sekarang tentunya tidak dimaksudkan untuk menjadi pedoman yang komprehensif dalam pencegahan kebakaran. Namun dengan berbagi hasil riset ini, diharapkan pengetahuan dan pengalaman yang ada di buku ini bisa menjadi perbandingan dari usaha-usaha serupa yang ada, serta bisa diperbanyak dan diperluas (scale out and up) untuk daerah-daerah lain, dengan memperhatikan konteks biofisik, sosial dan ekonomi yang ada.

Buku ini terdiri dari sembilan pembelajaran yang bisa dibaca secara runut atau tidak runut, yaitu:

- Pembelajaran 1: Teori dan Pelaksanaan Riset Aksi Partisipatif untuk Pencegahan Kebakaran dan Restorasi Gambut Berbasis Masyarakat

- Pembelajaran 2: Perubahan Perilaku Pembakaran dan Pencegahan Kebakaran di Riau

- Pembelajaran 3: Model Bisnis Berkelanjutan bagi Masyarakat untuk Pencegahan Kebakaran dan Restorasi di Lahan Gambut

- Pembelajaran 4: Pembangunan Sekat Kanal dan Pemantauan Tinggi Muka Air

- Pembelajaran 5: Penyiapan Lahan Tanpa Bakar untuk Pencegahan Kebakaran Hutan dan Lahan

- Pembelajaran 6: Penanaman di Lahan Gambut

- Pembelajaran 7: Penguatan Masyarakat Peduli Api: Pembelajaran dari Sebuah Riset Aksi Partisipatif

- Pembelajaran 8: Pengembangan Lembaga Kelompok Tani Hutan di Desa Dompas

- Pembelajaran 9: Sistem Pemantauan Restorasi Gambut Berbasis Masyarakat atau Community-based Peatland Restoration Monitoring System (CO-PROMISE)

Pada akhirnya kami berharap buku pembelajaran ini bermanfaat bagi para praktisi, profesional, penyuluh, perusahaan, pendamping masyarakat, lembaga swadaya masyarakat, donor dan pemerintah di berbagai tingkatan. Buku ini tentunya jauh dari sempurna. Masukan dan kritik yang konstruktif sangat kami nantikan untuk perbaikan buku ini pada edisi berikutnya.

Bogor, 1 Januari 2020

\section{Penulis}




\section{Kata Pengantar}

Mengingat Asia adalah wilayah yang menghadapi berbagai jenis bencana, masyarakat kita harus lebih dipersiapkan. Oleh karenanya, mendorong pertukaran internasional dan meningkatkan kemampuan regional di bidang kesiapsiagaan menghadapi bencana merupakan area fokus utama Temasek Foundation. Selain itu, masalah-masalah yang dihadapi oleh satu komunitas dapat mempengaruhi komunitas yang lain. Oleh karena itu, sebagai tetangga dan kawan di kawasan ini, penting bagi kita untuk saling berbagi dan bertukar gagasan, bekerja bersama-sama, dan untuk belajar dari satu sama lain.

Buku pegangan ini menyajikan berbagai pengalaman dan pembelajaran yang diperoleh melalui penelitian dan elaborasi upaya-upaya di lapangan, sebagai bagian dari Program Pencegahan Kebakaran dan Restorasi Gambut Berbasis Masyarakat. Dengan merangkul sejumlah ahli dan mitra dari Asia dan sekitarnya, program ini berfokus pada pengembangan model-model berbasis masyarakat dan gagasan tentang pencegahan kebakaran dan restorasi gambut di Indonesia.

Saya sangat berterima kasih kepada semua mitra yang terlibat, untuk antusiasme, kepemimpinan dan kontribusinya bagi keberhasilan program ini. Mitra-mitra kami adalah: Pusat Penelitian Kehutanan Internasional (CIFOR); Pusat Studi Bencana Universitas Riau (PSB UNRI); Commonwealth Scientific and Industrial Research Organisation, Australia (CSIRO); Universitas Gadjah Mada (UGM) dan Singapore Cooperation Enterprise (SCE). Kami berharap buku pegangan ini dapat digunakan sebagai acuan yang bermanfaat bagi masyarakat yang menghadapi masalah yang sama dan juga dapat menjadi batu loncatan untuk lebih banyak lagi diskusi kolaboratif dan gagasan-gagasan tentang pencegahan kebakaran dan restorasi gambut.

\section{Benedict Cheong}

Chief Executive

Temasek Foundation International 


\section{Ucapan Terima Kasih}

Buku ini merupakan hasil dari Riset Aksi Partisipatif (RAP) untuk Pencegahan Kebakaran dan Restorasi Gambut Berbasis Masyarakat. Kami berterima kasih atas partisipasi aktif dari pengelola arena aksi di Desa Dompas, terutama Kelompok Tani Hutan "Dompas Ghedang Cemerlang"; Masyarakat Peduli Api (MPA) Dompas, kelompok-kelompok masyarakat di Kecamatan Bukit Batu dan Kecamatan Siak Kecil, Kabupaten Bengkalis; Pemerintah Desa Dompas; Pemerintah Kecamatan Bukit Batu; Pemerintah Kabupaten Bengkalis; Pemerintah Provinsi Riau, dan UPT KPH Bengkalis Pulau. Kami juga berterima kasih kepada Badan Restorasi Gambut (BRG), World Wildlife Fund (WWF) Riau, Dinas Lingkungan Hidup Kabupaten Bengkalis dan Badan Penanggulangan Bencana Daerah (BPBD) Provinsi Riau, atas kerjasamanya yang baik dalam proses pelaksanaan RAP dan lokakarya diseminasi hasil riset. Terima kasih kepada semua pihak yang telah membantu riset ini, termasuk para responden yang berada di Kabupaten Bengkalis, Siak dan Pelalawan.

Kami menyampaikan terima kasih kepada pendukung dana riset ini, Temasek Foundation (TF), dan pengelola program terkait, Singapore Cooperation Enterprise (SCE). Terima kasih kepada para mitra peneliti dari Universitas Riau, Universitas Gadjah Mada, dan Elois Caitlin dari University of Western Australia. Terima kasih kepada Dr. Geremy Farr-Wharton, Dr. Fitri Nufatriani, Dr. Nunung Parlinah, Bapak Bayuni Shantiko, Bapak Hari Priyadi Rusantoyo, Ibu Nining Liswanti, Bapak Sigit Deni Sasmito dan para pengulas anonim, atas kontribusinya sebagai pengulas buku RAP ini. Kami juga berterima kasih atas masukan dan saran para peserta lokakarya yang telah meninjau draf buku ini pada tanggal 3 Desember 2019. Terima kasih kepada Dr. Ani Widayatsari, Ibu Fitri Heryani, Ibu Made Dwi Astuti, Ibu Mira Handayani, Ibu Karina Palar, dan Ibu Sonya Dyah Kusumadewi atas dukungan administratif. Akhir kata, kami ucapkan terima kasih kepada para kawan penulis, pengulas, editor Bahasa Indonesia, tim lapangan dan semua pihak yang telah memberikan masukan selama pelaksanaan RAP maupun penyusunan buku ini.

\section{Penulis}




\section{Ringkasan}

Buku "Pembelajaran dari Pencegahan Kebakaran dan Restorasi Gambut Berbasis Masyarakat" ini disusun berdasarkan studi kasus riset aksi partisipatif (RAP) yang dilakukan di Provinsi Riau oleh Pusat Penelitian Kehutanan Internasional (CIFOR), Pusat Studi Bencana Universitas Riau (PSB UNRI), the Commonwealth Scientific and Industrial Research Organisation (CSIRO) dan Universitas Gadjah Mada (UGM). Hasil studi ini menunjukkan bahwa RAP merupakan jawaban atas kebutuhan untuk memahami dinamika dan membuat perubahan di tingkat tapak secara simultan. Dalam RAP, masyarakat merupakan mitra peneliti yang bersama-sama memahami permasalahan, mencari solusi, mengalami implementasi, melihat dan mengevaluasi solusi. Pemahaman tentang konsep, landasan filosofis dan langkah-langkah dalam menerapkan pendekatan RAP, termasuk metode-metode yang dapat digunakan dalam mencapai tujuan RAP kami rangkum pada pembelajaran pertama yang berjudul "Teori dan Pelaksanaan Riset Aksi Partisipatif untuk Pencegahan Kebakaran dan Restorasi Gambut Berbasis Masyarakat". Pada bagian ini, kami menyediakan pedoman bagi peneliti, praktisi, maupun akademisi untuk melakukan riset aksi partisipatif di tingkat lokal agar dapat memperoleh hasil dan dampak yang jelas selama pelaksanaan proyek maupun setelah proyek berakhir.

Menyadari pentingnya keberlanjutan hasil dan dampak berbagai proyek atau program pencegahan kebakaran, yang salah satunya dapat dicapai melalui perubahan perilaku, maka pembelajaran kedua dari buku ini berfokus pada "Perubahan Perilaku Pembakaran dan Pencegahan Kebakaran di Riau". Penting diingat bahwa praktikpraktik alternatif tanpa pembakaran membutuhkan tenaga kerja dan sumber daya keuangan yang jauh lebih besar. Sejak larangan pembakaran secara ketat diterapkan, para petani dipaksa untuk membekali diri mereka dengan pengetahuan dan keterampilan yang baru, serta tenaga kerja dan biaya terkait peralatan/mesin, bahan kimia dan pupuk yang lebih tinggi. Akibatnya, petani miskin terdampak secara lebih parah dengan keharusan mengadopsi praktik-praktik tanpa pembakaran. Oleh karena itu, program-program pencegahan kebakaran yang dapat membantu penduduk desa untuk beradaptasi mengelola lahan tanpa pembakaran, sekaligus dapat mencukupi penghidupannya, menjadi kunci keberhasilan keberlanjutan hasil dan dampak program-program tersebut. 
Sebagai bagian dari upaya memperoleh praktik-praktik alternatif yang berkelanjutan, formulasi model bisnis menjadi bagian penting dalam RAP. Model bisnis sering kali dikaitkan dengan pendirian bisnis skala besar. Namun, bagaimana model bisnis ini dapat diaplikasikan pada tingkat lokal dan digunakan oleh masyarakat untuk mengembangkan bisnis skala mikro maupun kecil masih belum banyak diketahui. Melalui pembelajaran ketiga "Model Bisnis Berkelanjutan bagi Masyarakat untuk Pencegahan Kebakaran dan Restorasi di Lahan Gambut", kami membagikan pengalaman fasilitasi intensif kepada kelompok-kelompok masyarakat di Desa Dompas dalam menyusun dan mengujicobakan beragam kanvas model bisnis, yaitu untuk ekowisata, wanatani nanas, dan kopi liberika. Tersedianya alat untuk formulasi model bisnis akan memudahkan proses identifikasi dan pemetaan gagasan masyarakat. Dengan fokus pada pencegahan kebakaran dan restorasi gambut, kami menyarankan sebuah kerangka kerja dan alat model bisnis yang diperbarui, yakni Model Bisnis Berkelanjutan bagi Masyarakat atau Sustainable Business Model for Community.

Selain pendekatan perubahan perilaku dan alat bantu model bisnis yang disebutkan di atas, pengendalian kondisi tinggi muka air tanah dan kondisi hidrologis juga menjadi kunci dalam upaya-upaya pencegahan kebakaran dan restorasi gambut. Pada pembelajaran keempat berjudul "Pembangunan Sekat Kanal dan Pemantauan Tinggi Muka Air", kami menyampaikan sebuah alat bantu dalam kegiatan pembangunan sekat kanal, yang tidak saja berkualitas tinggi dan tahan lama, tetapi juga optimal dan dirasakan manfaatnya oleh berbagai pihak. Pembangunan sekat kanal ditujukan untuk meningkatkan tinggi muka air tanah di wilayah sekitar lokasi sekat kanal. Pada banyak kasus sebelumnya ditemui bahwa banyak kerusakan infrastruktur pembasahan yang telah dibangun terjadi akibat perencanaan, serta proses sosialisasi dan diskusi yang tidak memadai. Dari hasil riset yang telah dilakukan, kami melihat bahwa selayaknya pembangunan infrastruktur mengutamakan proses partisipatif. Dengan menggunakan kerangka kerja RAP, kami menggambarkan rangkaian petunjuk mengenai pembangunan sekat kanal dan pemantauan dampak sekat kanal terhadap pembasahan gambut. Rangkaian ini merupakan alat bantu yang disusun berdasarkan hasil uji coba dan aplikasinya di Desa Dompas, Kecamatan Bukit Batu, Kabupaten Bengkalis, Riau.

Selain melakukan pembangunan sekat kanal untuk mengendalikan pembasahan gambut, lahan atau arena aksi di lokasi uji coba Desa Dompas juga perlu dipersiapkan secara optimal untuk mendukung keberhasilan komoditas yang dibudidayakan. Dalam pembelajaran kelima "Penyiapan Lahan Tanpa Bakar untuk Pencegahan Kebakaran Hutan dan Lahan", kami membagikan pengalaman dalam fasilitasi Penyiapan Lahan Tanpa Bakar (PLTB) sebagai upaya pengelolaan lahan secara berkelanjutan. Alternatif penyiapan lahan tanpa bakar merupakan bagian penting dalam rangka pencegahan kebakaran melalui perubahan perilaku masyarakat. Penyiapan lahan dengan cara 
membakar kerap dilakukan karena dianggap mudah, murah, dan cepat, namun dampak-dampak negatifnya sering tidak disadari dan dipahami dengan baik. Meskipun lebih mahal, PLTB dalam jangka panjang akan memberikan banyak keuntungan, seperti lebih tingginya nilai unsur hara yang tersedia di lahan, dan diperolehnya limbah kayu atau limbah lainnya yang dapat dimanfaatkan sehingga memberikan nilai tambah. Selain itu PLTB juga bersifat lebih ramah terhadap lingkungan, tidak menimbulkan asap, dan tidak mengganggu kegiatan sosial dan ekonomi (kesehatan dan transportasi).

Dalam konteks upaya restorasi gambut, tahap selanjutnya setelah penyiapan lahan adalah proses penanaman kembali atau revegetasi, yang disampaikan pada pembelajaran keenam dalam buku ini, yaitu mengenai “Penanaman di Lahan Gambut". Pada bab ini kami menjabarkan kegiatan uji coba lapangan dalam rangka pencegahan kebakaran dan restorasi gambut yang difokuskan di Desa Dompas, Kecamatan Bukit Batu, Kabupaten Bengkalis, Provinsi Riau. Selain sebagai bentuk kegiatan dalam rangka pemulihan fungsi ekosistem gambut, penanaman kembali juga difokuskan pada upaya revitalisasi penghidupan masyarakat. Uji coba lapangan dilakukan pada arena aksi seluas 11,1 ha dengan komoditas-komoditas yang telah dipilih dan dibangun model bisnisnya. Pada bab ini kami berbagi panduan budidaya kopi liberika, nanas dan kelapa hibrida di lahan gambut. Panduan ini memberikan petunjuk budidaya untuk komoditas-komoditas tersebut yang dikembangkan berdasarkan kegiatan pelatihan yang dilaksanakan selama RAP.

Upaya pencegahan kebakaran, khususnya di lahan gambut, tidak bisa lepas dari kesiapsiagaan masyarakat yang berada di sekitarnya. Masyarakat Peduli Api (MPA) merupakan kumpulan individu masyarakat yang secara sukarela peduli terhadap pengendalian kebakaran hutan dan lahan. MPA disadari merupakan garda terdepan dalam pencegahan dan penanggulangan kebakaran, namun MPA masih menghadapi berbagai kendala yang menyebabkan mereka tidak bisa berfungsi secara optimal, seperti lemahnya kemampuan kelompok dalam berorganisasi, kurangnya pemahaman gugus tugas sebagai relawan, terbatasnya sarana, prasarana dan dukungan pembiayaan. Oleh karena itu, melalui pembelajaran ketujuh yang berjudul "Penguatan Masyarakat Peduli Api: Pembelajaran dari Sebuah Riset Aksi Partisipatif”, kami membagikan pengalaman dalam upaya penguatan MPA. Penguatan MPA menjadi salah satu langkah penting dalam menyiapkan kelompok relawan ini agar dapat menjalankan peran dan tugasnya secara efektif dan optimal. Pembelajaran ini disusun berdasarkan pembelajaran dari sebuah riset aksi partisipatif bersama lima MPA di Kabupaten Bengkalis, Provinsi Riau. Dengan melihat lebih dalam peran, fungsi, struktur, dan cara kerja MPA, pembelajaran ini dimaksudkan untuk membantu para pihak agar dapat secara bertahap memenuhi persyaratan teknis, prosedural dan administratif MPA, sebagai bagian dari penguatan MPA, agar MPA dapat berperan secara efektif dan optimal. 
Pada proses perjalanan riset aksi partisipatif (RAP), CIFOR bersama masyarakat Desa Dompas, Kecamatan Bukit Batu, Kabupaten Bengkalis, Riau, menyadari perlunya membentuk lembaga Kelompok Tani Hutan (KTH) sebagai persyaratan formal untuk dapat beraktivitas di dalam kawasan hutan. Pembentukan dan penguatan lembaga ini merupakan salah satu bagian penting dalam pelaksanaan RAP untuk pencegahan kebakaran dan restorasi gambut, yang akan dimotori oleh KTH. Pada pembelajaran kedelapan mengenai "Pengembangan Lembaga Kelompok Tani Hutan di Desa Dompas", kami mendokumentasikan proses dan hasil RAP dalam pembentukan dan penguatan kelembagaan masyarakat yang berperan penting sebagai penggerak pembangunan di tingkat tapak, khususnya terkait keberdayaan ekonomi masyarakat, pencegahan kebakaran dan restorasi gambut. Dokumentasi dari proses ini diharapkan dapat menjadi bahan pembelajaran dan berbagi pengetahuan dan pengalaman bagi masyarakat dan para pihak, terutama para pegiat atau mitra pembangunan yang terlibat dalam pemberdayaan masyarakat pedesaan.

Pada akhirnya, sebagai bagian dari upaya yang dilakukan untuk keberlanjutan dampak dan hasil program, pemantauan menjadi bagian penting untuk evaluasi keberhasilan program dan untuk perbaikan kegiatan-kegiatan berikutnya. Dalam melaksanakan RAP, proses dan hasil dipantau secara partisipatif bersama dengan masyarakat melalui sistem pemantauan berbasis masyarakat. Pada pembelajaran kesembilan berjudul "Sistem Pemantauan Restorasi Gambut Berbasis Masyarakat atau Communitybased Peatland Restoration Monitoring System (CO-PROMISE)" kami membagikan pengalaman membangun dan menggunakan sistem pemantauan dalam kegiatan restorasi di lahan gambut. CO-PROMISE dirancang agar mudah digunakan oleh semua pihak tanpa mengurangi kualitas data. Sistem ini memungkinkan penyimpanan data hasil pengukuran secara berkala yang bisa ditampilkan pada dashboard dan disesuaikan dengan kebutuhan pengguna. CO-PROMISE terdiri dari beberapa jenis pemantauan berdasarkan pendekatan restorasi 3R (Rewetting, Revegetation, Revitalization), yakni pembasahan gambut, penanaman pohon kayu, dan revitalisasi penghidupan masyarakat setempat. Seluruh informasi pengukuran dan hasil pemantauan dilengkapi dengan titik koordinat lokasi dan disajikan secara visual.

Buku ini memuat loop pertama dari tahapan berulang RAP yang merangkum perjalanan dari fase refleksi, perencanaan, aksi atau implementasi, dan pemantauan dengan fokus pada topik-topik yang berbeda namun dalam prosesnya saling terkait satu sama lain. Pembelajaran 1 sampai dengan 9 merupakan rangkuman dari proses terintegrasi dalam pencegahan kebakaran dan restorasi gambut berbasis masyarakat, yang dilaksanakan dalam kerangka kerja riset aksi partisipatif. 


\section{Daftar Penulis}

\section{Prof. Dr. Herry Purnomo}

IImuwan, CIFOR; Guru Besar Fakultas Kehutanan, IPB University; Pemimpin proyek riset aksi partisipatif - h.purnomo@cgiar.org

\section{Dr. Nurul Qomar}

Dosen Jurusan Kehutanan, Fakultas Pertanian, Universitas Riau; Pusat Studi Bencana Universitas Riau; Pemimpin proyek riset aksi partisipatif di PSB UNRI nqomar@lecturer.unri.ac.id

\section{Dr. Daniel Mendham}

IImuwan riset utama, CSIRO; Pemimpin proyek riset CSIRO -

Daniel.Mendham@csiro.au

Prof. Dr. Ashaluddin Jalil

Guru Besar Fakultas IImu Sosial dan IImu Politik, Universitas Riau; Pusat Studi

Bencana Universitas Riau - ashaluddin.jali@@lecturer.unri.ac.id

\section{Dr. Adhy Prayitno}

Dosen Jurusan Teknik Kimia, Fakultas Teknik, Universitas Riau; Pusat Studi Bencana Universitas Riau - adhyprayitno_hadi@eng.unri.ac.id

\section{Dr. Ahmad Muhammad}

Dosen Jurusan Biologi, Fakultas MIPA, Universitas Riau; Pusat Studi Bencana Universitas Riau - aboveandbelowground@gmail.com

\section{Dr. Deden Djaenudin}

Peneliti, Pusat Litbang Sosial, Ekonomi, Kebijakan dan Perubahan Iklim, Kementerian Lingkungan Hidup dan Kehutanan - dendja07@yahoo.com.au

\section{Dr. Eko B. Hardiyanto}

Dosen Fakultas Kehutanan, Universitas Gadjah Mada - ebhardiyanto@ugm.ac.id

\section{Dr. Fitri Nurfatriani}

Peneliti, Pusat Litbang Sosial, Ekonomi, Kebijakan dan Perubahan Iklim, Kementerian Lingkungan Hidup dan Kehutanan - nurfatriani@yahoo.com 


\section{Dr. Haris Gunawan}

Deputi IV Riset dan Pengembangan, Badan Restorasi Gambut haris.gunawan@brg.go.id

\section{Dr. Himlal Baral}

IImuwan senior, CIFOR - h.baral@cgiar.org

\section{Dr. Imam Basuki}

Konsultan riset, CIFOR; Peatland Hydrology and Oil Palm Scientific Lead, Winrock International-i.basuki@cgiar.org; imambasuki1974@gmail.com

\section{Dr. John Gardner}

Ketua Tim Konsumen dan Penggunaan Sumber Daya, CSIRO John.Gardner@csiro.au

\section{Dr. Lailan Syaufina}

Wakil Dekan Bidang Akademik dan Kemahasiswaan Fakultas Kehutanan, IPB University; Dosen Fakultas Kehutanan, IPB University - lailans@apps.ipb.ac.id

\section{Dr. Lukas Rumboko Wibowo}

Peneliti, Pusat Litbang Sosial, Ekonomi, Kebijakan dan Perubahan Iklim, Kementerian Lingkungan Hidup dan Kehutanan - Irumboko@yahoo.com

\section{Dr. Murni Po}

IImuwan, CSIRO - murni.po@csiro.au

\section{Dr. Nunung Parlinah}

Peneliti, Pusat Litbang Sosial, Ekonomi, Kebijakan dan Perubahan Iklim, Kementerian Lingkungan Hidup dan Kehutanan - nparlinah@gmail.com

\section{Dr. Sigit Sutikno}

Kepala, Pusat Studi Bencana Universitas Riau; Dosen, Universitas Riau ssutiknoyk@yahoo.com

\section{Dr. Tuti Herawati}

Kepala Sub Direktorat Penyiapan Hutan Kemasyarakatan, Direktorat Penyiapan Kawasan Perhutanan Sosial- tutiherawatie29@gmail.com

\section{Aenunaim}

Periset, ICRAF - aenunaim@cgiar.org

\section{Agus Andrianto}

Asisten riset, CIFOR - a.andrianto@cgiar.org

\section{Ahmad Dermawan}

IImuwan, CIFOR - a.dermawan@cgiar.org 


\section{Beni Okarda}

Research senior officer, CIFOR - b.okarda@cgiar.org

\section{Dyah Puspitaloka}

Konsultan riset, CIFOR - d.puspitaloka@cgiar.org

\section{Hari Priyadi Rusantoyo}

Penasehat teknis, World Bank Indonesia; Associate Fakultas Ekonomi dan Manajemen, IPB University - haripriyadi@gmail.com

\section{Heru Komarudin}

Periset, CIFOR - h.komarudin@cgiar.org

\section{Gunawan Wibisono}

Dosen Fakultas Kehutanan, Universitas Gadjah Mada - mgwibisono@ugm.ac.id

\section{Muhammad Mardhiansyah}

Dosen Jurusan Kehutanan, Fakultas Pertanian, Universitas Riau mardhi98@yahoo.com

\section{Pandam Nugroho Prasetyo}

Spesialis kehutanan, PT Hatfield Indonesia - pandam@hatfieldgroup.com

\section{Qori Pebrial Ilham}

Dosen Fakultas Kehutanan, IPB University - qoripebrialilham@yahoo.com

\section{Rafi Merbamas}

Fasilitator desa, BRG - merbamas@gmail.com

\section{Rozi}

Masyarakat Peduli Api, Desa Dompas

\section{Shintia Arwida}

Reporting officer, UNOPS - shintiaa@unops.org

\section{Tarsono}

Fasilitator lokal, CIFOR - tarsono.renggo@gmail.com

\section{Usman Muchlish}

Senior research data officer, CIFOR - u.muchlish@cgiar.org

\section{Yesi}

Dosen Jurusan Sosiologi, Fakultas IImu Sosial dan IImu Politik, Universitas Riau;

Pusat Studi Bencana Universitas Riau - yesi.y@lecturer.unri.ac.id

\section{Zulkardi}

Fasilitator lokal, CIFOR - zulkardi444@gmail.com 


\section{Daftar Singkatan}

$3 R$

AA

$\mathrm{ACM}$

$A D$

APL

ART

BBSLDP

BMC

BPBD

BRG

BUMDes

CBMPT

CIFOR

CO-PROMISE

$\mathrm{CO}_{2}$

CSIRO

CSO

CSR

FAO

FGD

Gapoktan

Gapoktanhut

GPS

HTI

IAD
Rewetting, Revegetation, Revitalization of Livelihood (pembasahan kembali, revegetasi, revitalisasi mata pencaharian)

Arena Aksi

Adaptive Collaborative Management (pengelolaan adaptif kolaboratif)

Anggaran Dasar

Area Penggunaan Lain

Anggaran Rumah Tangga

Balai Besar Litbang Sumber Daya Lahan Pertanian

Business Model Canvas (kanvas model bisnis)

Badan Penanggulangan Bencana Daerah

Badan Restorasi Gambut

Badan Usaha Milik Desa

Circular Business Model Planning Tool (alat perencanaan model bisnis sirkular)

Center for International Forestry Research

Community-based Peatland Restoration Monitoring System (sistem

pemantauan restorasi gambut berbasis masyarakat)

Karbon dioksida

Commonwealth Scientific and Industrial Research Organization

Civil Society Organization (organisasi masyarakat sipil)

Corporate Social Responsibility (tanggung jawab sosial perusahaan)

Food and Agriculture Organization (organisasi pangan dan pertanian)

Focus Group Discussion (diskusi kelompok terarah)

Gabungan Kelompok Tani

Gabungan Kelompok Tani Hutan

Global Positioning System (sistem pemosisian global)

Hutan Tanaman Industri

Institutional Analysis and Development (analisis kelembagaan dan pembangunan) 
ID

ISO

Kemenko

KHG

$\mathrm{KTH}$

KUBE

LSM

MBC

Menko

MPA

ODK-collect

PAR CBFPR

PLTB

Poktan

PSB UNRI

RAP

SBMC

SCE

SES

SOP

SVLK

TF

TLBMC

TMA

ToC

UAV

UKM

UPT KPH

URL

UUD

ZOPP
Identity (identifikasi unik)

International Organization for Standardization (organisasi

internasional untuk standarisasi)

Kementerian Koordinator

Kawasan Hidrologi Gambut

Kelompok Tani Hutan

Kelompok Usaha Bersama

Lembaga Swadaya Masyarakat

Model Business Canvas (kanvas model bisnis)

Menteri Koordinator

Masyarakat Peduli Api

Open Data Kit-collect

Participation Action Research to Community-Based Fire Prevention and Peatland Restoration (riset aksi partisipatif untuk pencegahan kebakaran dan restorasi gambut berbasis masyarakat)

Penyiapan Lahan Tanpa Bakar

Kelompok Tani

Pusat Studi Bencana Universitas Riau

Riset Aksi Partisipatif

Sustainable Business Model for Community (model bisnis

berkelanjutan bagi masyarakat)

Singapore Cooperation Enterprise

Social-Ecological System (sistem sosio-ekologis)

Standar Operasi Prosedur

Sistem Verifikasi Legalitas Kayu

Temasek Foundation

Triple Layered Business Model Canvas (kanvas model bisnis tiga lapisan)

Tinggi Muka Air

Theory of Change (teori perubahan)

Unmanned Aerial Vehicle (pesawat tanpa awak)

Usaha Kecil dan Menengah

Unit Pelaksana Teknis Kesatuan Pemangku Hutan

Uniform Resource Locator (lokator sumber seragam)

Undang-Undang Dasar

Zielorientierte Projektplanung (metode perencanaan yang

berorientasi pada objektif proyek) 



\section{Pembelajaran 1}

\section{Teori dan Pelaksanaan Riset Aksi Partisipatif untuk Pencegahan Kebakaran dan Restorasi Gambut Berbasis Masyarakat}

Herry Purnomo, Dyah Puspitaloka, Heru Komarudin, Agus Andrianto, Beni Okarda, Imam Basuki, Pandam Prasetyo, Nurul Qomar, Ahmad Muhammad, Sigit Sutikno, Ashaluddin Jalil, Yesi, Haris Gunawan, Zulkardi, Rafi Merbamas, Tarsono dan Lukas Rumboko Wibowo 


\subsection{MENGAPA RISET AKSI PARTISIPATIF?}

Masyarakat global menghadapi tiga masalah besar, yaitu ketersediaan dan akses pangan, kemiskinan dan kerusakan lingkungan, termasuk gambut. Sebanyak 822 juta penduduk dunia menderita kelaparan kronis dan sekitar dua milyar orang mengalami defisiensi gizi (FAO 2019), sekitar tujuh juta hektar hutan dunia mengalami deforestasi setiap tahunnya (FAO 2016) dan suhu global bumi yang terus memanas yang akan mencapai empat derajat celcius pada akhir abad 21 (World Bank 2012). Kita berpacu dengan waktu untuk memperbaiki keadaan ini, baik pada tingkat global, nasional dan lokal. Ilmuwan, pegiat dan praktisi sedunia sedang berkontribusi terhadap penyelesaian masalah pangan, kemiskinan dan perbaikan lingkungan. Pertanyaannya, bagaimana itu bisa dilakukan secara efisien dan efektif?

Kelestarian hutan, gambut dan lingkungan menjadi harapan banyak pihak, yang selalu disampaikan oleh pemerintah, masyarakat, pegiat lembaga swadaya masyarakat (LSM) dan pemerhati hutan di seluruh Indonesia dan dunia. Namun demikian deforestasi terus terjadi dengan luasan 0,5 juta ha per tahun. Bencana kebakaran dan asap tahun 2015 dengan kerugian ratusan trilyun rupiah berlanjut sampai saat ini. Bencana hidrometeorologis yang terus melanda serta konflik gajah dan manusia adalah contohcontoh tata kelola (governance) hutan dan lingkungan yang belum baik.

Keharusan untuk melakukan pengelolaan sumber daya alam yang menguasai hajat hidup orang banyak secara berkelanjutan dan berwawasan lingkungan merupakan amanat konstitusi. Hasil amandemen keempat UUD 1945 Pasal 33 Ayat 4 menyatakan, "Perekonomian nasional diselenggarakan berdasar atas demokrasi ekonomi dengan prinsip kebersamaan, efisiensi, berkeadilan, berkelanjutan, berwawasan lingkungan, kemandirian, serta dengan menjaga keseimbangan kemajuan dan kesatuan ekonomi nasional". Konstitusi mengamanatkan bahwa tata kelola hutan, lahan dan gambut harus dirancang untuk kemajuan ekonomi, kelestarian lingkungan dan keadilan sosial.

Sudah banyak ide, narasi dan argumentasi bagaimana pembangunan dapat berjalan tanpa menimbulkan dampak negatif terhadap lingkungan dan masyarakat, serta bagaimana upaya-upaya pencegahan kerusakan lingkungan dapat dilakukan secara efektif. Namun, seringkali ide, narasi dan argumentasi tersebut tidak mencakup kompleksitas dan keunikan setiap tapak, daerah atau masyarakat tertentu. Selain itu, argumentasi dan klaim kebenaran atau keberhasilan sebuah inisiatif tidak disertai evidence atau fakta lapangan, sehingga pembelajaran yang muncul sulit untuk diikuti dan disebarluaskan. Jika dilakukan, ide atau narasi tersebut tidak dapat mencapai tujuannya atau bahkan tidak relevan untuk dilakukan. Demikian juga dengan hasil temuan dan rekomendasi riset, yang tidak serta-merta relevan atau dapat dilaksanakan di lapangan. Tidak mudah untuk membayangkan masyarakat bisa diyakinkan dengan temuan dan mengikuti rekomendasi-rekomendasi tersebut. Oleh karena itu, tingkat intensitas partisipasi masyarakat harus disesuaikan dengan tujuan dari riset itu sendiri. 
Riset Aksi Partisipatif (disingkat RAP atau Participatory Action Research) adalah jawaban atas permasalahan tersebut. RAP memiliki sejarah panjang, yang telah dipraktekkan oleh para ilmuwan sosial untuk membantu menyelesaikan masalah praktis dalam situasi perang di Eropa dan Amerika. Ilmuwan lain menyatakan RAP berasal dari karya Kurt Lewin pada 1940-an (Reason dan McArdle 2004). Karakteristik pendekatan RAP yang pertama adalah bahwa RAP bersifat partisipatif, yaitu riset dilakukan peneliti utama bersama-sama masyarakat yang menjadi mitra peneliti (co-researchers) untuk memahami masalah dan mencari solusinya. Karakteristik kedua adalah bahwa RAP berorientasi pada aksi. Solusi yang ditemukan secara bersama-sama diimplementasikan di lapangan. Reason dan McArdle (2004) menyimpulkan bahwa RAP dilakukan oleh, dengan dan untuk orang, bukan penelitian tentang orang. Ini mengandung arti bahwa masyarakat dalam jangka waktu penelitian mengalami implementasi, dan dapat melihat apakah solusi yang ditemukan itu bisa dijalankan dan menyelesaikan masalah yang dihadapi. Mengalami langsung sebuah pembelajaran menjadi sebuah proses yang jauh lebih mendalam dan meyakinkan daripada sekedar mendengarkan dari orang lain. Dengan demikian, ketika RAP selesai dilakukan, outcome dan bahkan dampak (impact) dari sebuah riset sudah terjadi, sekalipun dalam skala yang kecil. Meskipun tidak tercakup dalam RAP, scale-up atau peningkatan dampak tentu perlu dilakukan.

Kebakaran hutan dan lahan (karhutla) adalah kasus nasional yang perlu ditangani oleh semua pihak. Purnomo dkk. (2017a) menyatakan bahwa kebakaran dilakukan secara disengaja dan dilakukan oleh organisasi yang rapi untuk mendapatkan keuntungan sebesar-besarnya dari budidaya tanaman. Kejahatan yang terorganisasi ini semakin diperkuat melalui kontestasi politik lokal lewat pemilihan kepala daerah (Purnomo dkk. 2019). Sangat diragukan bahwa tindakan pemerintah sendiri benar-benar dapat mengurangi kebakaran, mengingat 'keuntungan dari penggunaan api' yang diperoleh oleh beberapa aktor dan hubungan mereka yang kompleks dengan para elit lokal. Semua pihak termasuk pemerintah pusat dan daerah, sektor swasta, Lembaga Swadaya Masyarakat (LSM) dan organisasi masyarakat sipil (Civil Society Organization/ CSO) harus bertindak bersama untuk mencegah kebakaran. Masyarakat sebagai faktor kunci untuk mencegah kebakaran pada tingkat desa menjadi hal yang perlu dipahami secara lebih mendalam.

Riset yang berfokus pada keluaran berupa laporan dan artikel ilmiah sangat membantu memahami suatu sistem, masyarakat dan interaksinya. Namun demikian, dibutuhkan riset yang diarahkan untuk tidak saja memahami penyebab mendasar terjadinya kebakaran, tetapi juga bagaimana perubahan perilaku para aktor, terutama masyarakat dan pemangku kepentingan di sekitarnya bisa terjadi dan didorong ke arah upayaupaya pencegahan kebakaran sekaligus peningkatan kesejahteraan. Kuncinya adalah adanya partisipasi yang jelas dari masyarakat dan adanya rasa kepemilikan atas proses riset dan intervensi, dengan masyarakat menjadi pendorong utama atau setidaknya menjadi mitra peneliti. 
Bab ini memberikan pemahaman tentang konsep RAP, landasan filosofis, dan langkahlangkah dalam menerapkan pendekatan RAP, termasuk metode-metode yang dapat digunakan dalam mencapai tujuan. RAP adalah sebuah proses inklusif, yang di dalam proses tersebut masyarakat mengidentifikasi dan menganalisis masalah, dan bertindak untuk menemukan solusi dan mempromosikan transformasi sosial, ekonomi dan politik (Selener 1997). RAP adalah cara memahami masalah dan mengubah perilaku yang terjadi pada saat yang bersamaan.

Penyusunan bab ini didasarkan pada sebuah studi kasus tentang pencegahan kebakaran dan restorasi lahan gambut berbasis masyarakat di Riau - sebuah proyek riset aksi partisipatif yang didanai oleh Temasek Foundation (TF). Proyek penelitian tersebut dilaksanakan secara bersama-sama oleh Pusat Penelitian Kehutanan Internasional (CIFOR) dan Pusat Studi Bencana Universitas Riau (PSB UNRI) selama periode 2018-2019. Tujuan bab ini adalah untuk menyediakan sebuah pedoman dalam melakukan riset aksi di tingkat lokal agar menghasilkan hasil dan dampak yang jelas bagi para peneliti, sektor swasta, masyarakat, LSM, pejabat pemerintah dan praktisi. Hasil yang dicapai diharapkan tidak hanya diperoleh setelah proyek berakhir, namun juga selama pelaksanaan proyek.

\subsection{LANDASAN DAN PELAKSANAAN RISET AKSI PARTISIPATIF}

\subsubsection{Landasan riset aksi partisipatif}

Kolaborasi antara para pemangku kepentingan dapat dilakukan secara alami ketika individu-individu tidak dapat mengejar tujuan dengan kemampuannya sendiri (Ossowski 1999). Praksis kolaborasi dipengaruhi oleh dinamika sosial. Dimensi vital dari interaksi sosial adalah cara individu membenarkan tindakan mereka kepada orang lain. Boltanski dan Thévenot (2006) berpendapat bahwa justifikasi-justifikasi ini termasuk dalam enam kategori logis utama, yang dicontohkan oleh enam penulis: civic/bersifat kewarganegaraan (Rousseau), menyangkut kepentingan dan tujuan bersama; pasar (Adam Smith), tentang utilitas; industri (Saint-Simon), menyangkut efisiensi untuk mencapai tujuan; domestik (Bossuet), menyangkut hubungan; inspirasi (Agustinus), menyangkut nilai-nilai; dan ketenaran atau reputasi (Hobbes), menyangkut nama baik seseorang. Para penulis menunjukkan bagaimana justifikasi ini dapat saling bertentangan ketika orang berlomba untuk melegitimasi pandangan mereka.

Terkait komunikasi antar aktor, Habermas (1987) menyatakan bahwa komunikasi menjadi bermasalah jika rasional instrumentalitas menyaingi rasionalisasi nilai. Habermas (1987) lebih lanjut menjabarkan strategi aksi komunikatif untuk memfasilitasi komunikasi pada perspektif rasional yang berbeda-beda. Aksi komunikatif didefinisikan sebagai cara 
untuk mencapai pemahaman bersama dalam bidang sosial (Habermas 1987). Aksi dapat mengkomunikasikan rasionalitas dan menyajikan pemahaman timbal balik antar aktor, yang kemudian mengarah pada kesepakatan. Kami berhipotesis bahwa dalam kompleksitas kebakaran dan restorasi gambut, aksi komunikatif antara para pihak adalah salah satu cara untuk memajukan kolaborasi dan aksi. Komunikasi antar para pemangku kepentingan dapat mengubah preferensi mereka dan menciptakan nilainilai yang sama. Persepsi tidak dirumuskan sebelumnya (preformulated), melainkan dikonstruksi oleh dinamika sosial.

Pruzan (1994) seperti dikutip dalam Gamborg (2002) mengajukan tiga langkah-langkah mendasar, yakni identifikasi pemangku kepentingan (stakeho/der), pembagian nilai, dan kriteria untuk memenuhi kondisi-kondisi yang dimaksud oleh Habermas (1987) untuk diskursus praktis menuju aksi komunikatif. RAP adalah salah satu proses ketika anggota masyarakat mengidentifikasi masalah, mengumpulkan dan menganalisis informasi dan bertindak mengatasi masalah dengan mencari solusi dan mendorong transformasi-transformasi sosial dan politik (Selener 1997). Transformasi adalah tujuan dari manajemen kolaboratif adaptif (adaptive collaborative management/ACM) yang didefinisikan oleh Colfer (2005). Kusumanto dkk. (2005) menyampaikan contoh dari proses ACM di Sumatra yang menggunakan RAP sebagai kerangka kerja riset untuk meningkatkan kapasitas para pemangku kepentingan. Melalui RAP, masyarakat lokal dapat bertindak secara kolektif dan berpartisipasi dalam proses pengambilan keputusan terkait dengan hutan dan lahannya. RAP dilakukan melalui rangkaian berulang dari ‘refleksi-perencanaan-aksi-pemantauan' (Henocque dan Denis 2001).

RAP memiliki keterkaitan yang erat dengan teori sistem umum, teori kompleksitas, aksi komunikatif (Habermas 1987), sistem sosial ekologis (SES), dan analisis kelembagaan dan pembangunan (Institutional Analysis and Development/IAD) dari Ostrom (2007, 2010). Teori sistem umum mengemukakan adanya isomorfisme antar disiplin yang berbeda, sistem alami dan sosial. Pola solusi dari satu disiplin tertentu mungkin akan berlaku juga untuk disiplin-disiplin yang lain. Konservasi hutan, misalnya, memiliki kesamaan dan permasalahan yang serupa dengan konservasi laut dan pengelolaan tambang. Strategi-strategi peran dapat berlaku pula di dunia bisnis. Properti-properti pada level sistem muncul dan mungkin tidak dapat dimengerti dari komponenkomponennya. Teori kompleksitas berawal dari kegagalan prediksi linear yang berdasarkan paradigma Newtonian. Mengingat banyaknya ketidakpastian, perilaku sistem tidak dapat diprediksi, dan oleh karena itu pembelajaran dan kemampuan beradaptasi menjadi pusat inti dari pengelolaan sistem, termasuk sumber daya alam dan ekosistem. Komunikasi aksi menggarisbawahi pentingnya aksi sebagai media untuk mencapai kesepakatan. Aksi-aksi yang terkomunikasikan dengan baik akan memicu reaksi-reaksi dan aksi-aksi timbal balik, yang kemudian akan merumuskan kesepakatan dan kelembagaan sosial. SES menggunakan sebuah kerangka kerja yang menjelaskan bagaimana alam, pengelolaan, tata kelola, aktor dan politik terhubung dan berinteraksi. 
Kerangka IAD memberikan panduan tentang aspek-aspek kunci, yang mencakup aspek institusi, teknis dan partisipatif, dari suatu intervensi yang dilakukan terhadap komunitas yang mengelola sumber daya secara bersama dan bagaimana permasalahan bersama bisa diselesaikan. Bagian inti dari kerangka IAD adalah elemen arena aksi atau action arena, yang mencakup situasi aksi atau action situation, dan aktor atau actor. Situasi aksi mengacu pada ruang sosial tempat aktor saling berinteraksi, menyelesaikan masalah bersama dan bertukar barang atau jasa (Ostrom 2007, 2010). Melalui kerangka tersebut, tahapan analisis dilakukan dengan menggunakan arena aksi sebagai unit analisis dan secara sistematis mengikuti jalur pengambilan keputusan, yang dimulai dari tahap pra-perencanaan, perencanaan, eksekusi atau implementasi, dan bagaimana sebuah proyek bisa berkelanjutan. Dalam arena aksi, berbagai kepentingan yang berbeda dari para pihak didiskusikan dan sejumlah rencana kegiatan disusun berdasarkan kesepakatan.

Habermas (1968) membagi ilmu pengetahuan menjadi tiga paradigma, yaitu (1) Positivisme (ilmu empiris-analitis/instrumental knowledge), (2) Interpretatif/Humanistik (hermeneutic knowledge atau interpretative knowledge), dan (3) Kritis (emancipatory knowledge). Paradigma ketiga (kritis) memperjuangkan pendekatan yang bersifat holistik serta menghindari cara berfikir deterministik dan reduksionistik. Paradigma ini yang kemudian berkontribusi besar pada Action Research atau yang juga terkenal sebagai RAP. Pelaksanaan RAP, merujuk pada Reason dan Torbert (2001), bersandar pada asumsi epistemologis yang menyatakan bahwa tujuan penelitian dan wacana akademik bukan hanya untuk mendeskripsikan, memahami, dan menjelaskan keadaan dunia, melainkan bagaimana mengubahnya. Menurut Saidi (2015) paradigma kritis mendorong para peneliti untuk bisa mengubah realitas dengan cara yang partisipatoris dan emansipatoris, yaitu partisipasi yang membebaskan. Dalam konteks ini teori sosial kritis digunakan untuk mendorong perubahan.

\subsubsection{Teori perubahan}

RAP diterapkan selaras dengan Teori Perubahan (Theory of Change/ToC) yang harus dikembangkan pada semua jenis riset. ToC menjelaskan bagaimana perubahanperubahan dapat diteorikan dan diperoleh selama atau setelah implementasi proyek. Sebagai sebuah riset, ToC akhirnya dapat dan tidak dapat diperoleh; dan keduanya adalah subjek-subjek untuk temuan-temuan ilmiah. ToC menjelaskan secara jelas urutan dari aktivitas riset yang menghasilkan sejumlah keluaran, yang selanjutnya berkontribusi pada hasil-hasil dan dampak-dampak (Gambar 1.1). Berbagai keluaran yang dihasilkan dari riset menjadi salah satu bagian kontribusi untuk mencapai hasil. Selanjutnya, beberapa hasil-hasil bekerja dalam menghasilkan dampak-dampak. 


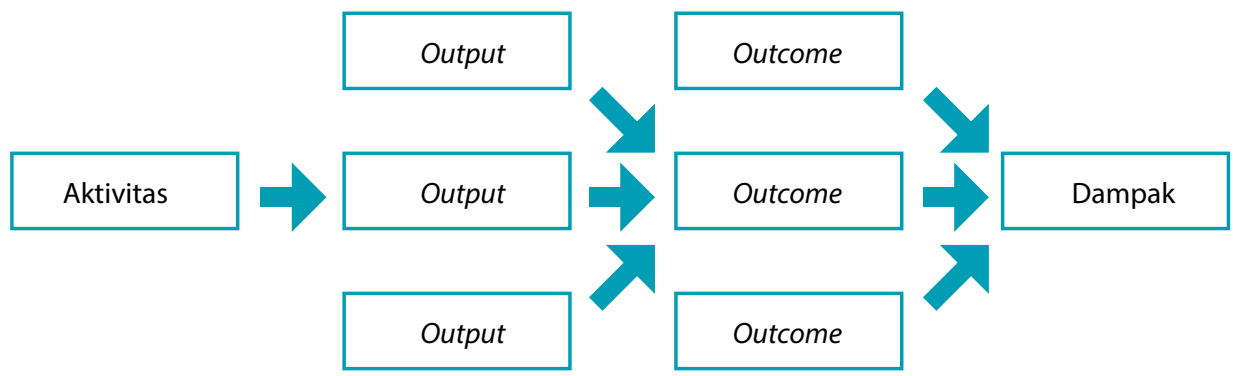

\section{Gambar 1.1 Hubungan linier antara aktivitas-aktivitas riset, keluaran (output), hasil (outcome), dan dampak-dampak.}

Aktivitas-aktivitas riset adalah apa yang sebenarnya dilakukan oleh para peneliti, misalnya pengumpulan data, diskusi kelompok terfokus (Focus Group Discussion/FGD), analisis data dan penglibatan masyarakat, para pembuat kebijakan dan LSM. Aktivitas riset mensintesa atau mentriangulasikan data dan informasi yang dikumpulkan dan menghasilkan sejumlah keluaran. Keluaran-keluaran ini dapat berupa artikel jurnal, laporan riset, policy brief, dan naskah akademik. Berbagai keluaran ini dikomunikasikan dan akan mempengaruhi pengguna-pengguna atau penerima manfaat yang dituju secara kolektif dengan keluaran riset-riset lainnya untuk selanjutnya memproduksi sejumlah hasil. Hasil-hasil yang signifikan akan mengubah perilaku penggunapengguna yang menjadi sasaran, misalnya masyarakat, pejabat pemerintah, dan sektor swasta untuk berkontribusi pada dampak-dampak yang dituju. Dampak-dampak adalah perubahan jangka panjang di tingkat tapak, misalnya pendapatan masyarakat lokal atau pemerintah yang lebih tinggi, tutupan hutan yang lebih banyak dan jasa lingkungan yang lebih baik. Hasil-hasil penelitian anda tidak sendirian dalam membuat perubahan-perubahan.

RAP diperlukan saat keterlibatan masyarakat adalah sebuah kunci dari pemahaman dan penyelesaian sejumlah permasalahan. Masyarakat menjadi sebuah pusat perubahan. Dalam RAP, perubahan yang terpusat pada manusia tidak hanya terjadi pada tingkat pemahaman dan solusi saja, namun juga terlaksana di arena yang nyata. RAP lebih dari sekedar riset partisipatif, ini adalah sebuah riset aksi yang dilakukan secara partisipatori. Riset aksi memastikan hasil-hasil riset dapat dipantau selama riset dilaksanakan. RAP memperlakukan para mitra, termasuk petani, sektor komersil, LSM dan pemerintah, sebagai rekan peneliti. RAP membuat mereka ingin tahu tentang berbagai cara dan pengetahuan baru untuk lebih memahami permasalahan yang mereka hadapi dan bertindak secara iteratif untuk membawa perbaikan. 
RAP yang dilaksanakan secara sistematik telah menghasilkan sejumlah kisah sukses, yaitu melalui pengelolaan hama terintegrasi di Jawa (Röling dan van de Fliert 1994). Masyarakat dan petani harus difasilitasi sehingga menjadi peneliti-peneliti yang dapat menyelesaikan permasalahan mereka sendiri. RAP dapat mendorong masyarakat, pemerintah, sektor komersil dan LSM untuk mengubah praktik dan kebijakan secara radikal dan tepat waktu untuk penghidupan dan sumber daya alam yang lebih baik. Perubahan ini akan mengarah pada perbaikan mata pencaharian, kesejahteraan, keadilan, konservasi lingkungan pada tingkat lokal maupun nasional, dan pada akhirnya berkontribusi pada perbaikan di tingkat global.

RAP bersifat transdisiplin, yang menginterasikan pendekatan multidisiplin dan kearifan lokal maupun global (local and global wisdoms). Multidisiplin mengkombinasikan disiplin seperti sosial, ekonomi, politik dengan biologi dan fisika. RAP membutuhkan waktu dan fasilitasi yang memadai untuk bekerja bersama masyarakat dalam memahami permasalahan, mencari solusi, bekerja di tingkat tapak maupun kebijakan, serta melakukan transformasi sosial. RAP sangat sesuai untuk negara-negara berkembang, yang para ilmuwannya tidak hanya dituntut untuk membuat publikasi di jurnal internasional yang bermutu, namun harus membuat perubahan di lapangan untuk memperbaiki kesejahteraan masyarakat, meningkatkan kapasitas tata kelola para pihak dan memperbaiki hutan dan lingkungan.

Kami telah melakukan RAP dalam konteks memperkuat kemitraan antara masyarakat dan perusahaan HTI di Sumatra Selatan, memperkuat kelembagaan perajin kayu dan fasilitasi penyusunan Peraturan Daerah (Perda) di Jepara, serta advokasi pencegahan kebakaran dan fasilitasi legal drafting untuk Rancangan Perda (Raperda) di Provinsi Riau. Hasil riset yang dinarasikan dalam sejumlah Perda ini memperluas (outscaling and upscaling) dampak riset aksi partisipatif yang sering hanya berfokus pada daerah tertentu, sehingga diperoleh hasil riset yang berkelanjutan.

Kemitraan antara masyarakat dan perusahaan HTI perlu diperkuat dengan mengembangkan forum atau dialog multipihak, memastikan keterwakilan masingmasing pihak secara tepat, menyeimbangkan kekuatan antar pihak, memperkuat perjanjian-perjanjian para pihak agar dilegalisasi secara hukum, serta memastikan reinforcement dari pihak luar. Tanpa perbaikan ini, maka kemitraan hanya menjadi 'sumbangan' (charity) dari pihak perusahaan, yang pada suatu saat tidak akan berkelanjutan, dan berpotensi pada berlanjutnya konflik-konflik berdarah di lapangan. Desain dan perjanjian yang mengikat dalam kemitraan para pihak dalam mengelola lanskap secara horizontal merupakan keharusan.

Secara vertikal, lanskap menghasilkan barang dan jasa. Perajin dan Usaha Kecil Menengah (UKM) perlu memperkuat diri dengan membentuk asosiasi yang formal dan berbadan hukum. Melalui asosiasi ini, kekuatan UKM menghadapi pasar, pengusaha 
besar, eksportir dan pemerintah menjadi lebih baik. Mereka dapat mengikuti pameran dagang lokal, nasional dan internasional serta dapat memasarkan produk-produknya. Selain itu mereka memperoleh sertifikasi legalitas kayu (SVLK) untuk ekspor yang bebas uji tuntas (due dilligence) ke pasar Uni Eropa. Penguatan kelembagaan perajin ini meningkatkan pendapatan dan kesejahteraan mereka. Pada akhirnya, dukungan politik dan keuangan pemerintah daerah yang diwajibkan oleh Perda dapat diperoleh secara bertahap (Purnomo dkk. 2009a, 2009b, 2011, 2014a).

\subsubsection{Fase-fase riset aksi partisipatif}

RAP dieksekusi melalui sebuah tahapan berulang dari inisiasi atau refleksi, perencanaan intervensi atau aksi dan pemantauan (Henocque dan Denis 2001; Purnomo dkk. 2014a) seperti disajikan pada Gambar 1.2. Para peneliti bekerja dalam kelompok fasilitasi untuk membantu para pemangku kepentingan dalam mengenali masalah-masalah mereka dan merekomendasikan solusi-solusi. Pada fase 'refleksi' para peneliti membentuk komunikasi melalui kunjungan lapangan, melakukan identifikasi para pemangku kepentingan dan konsultasi dengan mereka. Survei data dasar dilakukan untuk memahami isu-isu biofisik, sosial, dan mata pencaharian. Dalam fase ini, masalah yang dihadapi para pemangku kepentingan diidentifikasi secara bersama-sama. Dengan difasilitasi oleh para peneliti, para pemangku kepentingan kemudian menggambarkan sebuah rencana untuk mengatasi masalah-masalahnya (fase perencanaan). Suatu set indikator lokal dirancang untuk memantau implementasi dari riset aksi. Fase 'aksi' melaksanakan rencana tersebut secara partisipatif.

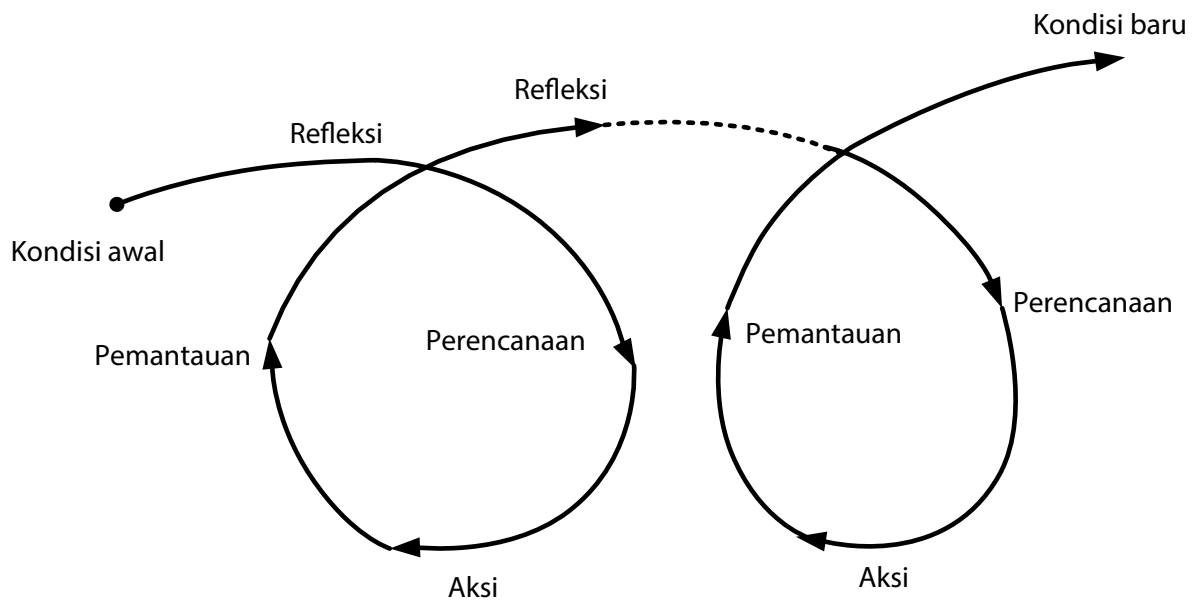

\footnotetext{
Gambar 1.2 Siklus riset aksi dari kondisi awal (t0) menuju kondisi tertentu (tn) setelah $\mathrm{n}$ loop.
} 
Fase pertama riset aksi adalah 'Refleksi' atas permasalahan yang ada serta tujuan yang diinginkan (Gambar 1.2). Mengumpulkan data dasar dari lapangan (baseline study), studi pasar dan rantai pasok/nilai komoditas, kondisi biofisik lapangan, konsultasi dengan para pihak dan meninjau (review) sains mutakhir (state of the art) yang relevan dilakukan pada fase ini. Analisis dilakukan untuk memahami bagaimana sistem bekerja dan mengenali titik-titik sensitif yang secara signifikan akan mempengaruhi outcome dari sistem tersebut. Pada fase ini sangat penting memahami insentif yang memungkinkan masyarakat untuk bisa dan bersedia berpartisipasi sepenuhnya dalam riset yang dilakukan.

Fase kedua, menyusun 'Rencana' untuk tindakan intervensi pada hal-hal yang sensitif yang bisa mendongkrak (leverage) sistem tersebut sesuai dengan tujuan yang diinginkan. Intervensi ini layaknya sebuah hipotesis yang harus diuji, yang artinya tidak ada jaminan bahwa aksi intervensi akan memberikan hasil sesuai dengan yang diharapkan. Jika kondisi tersebut tidak terpenuhi, maka hal tersebut bukan merupakan riset aksi, melainkan merupakan pembangunan (development). Fase perencanaan diikuti implementasinya berupa aksi. Fase ketiga, melakukan 'Aksi' sebagai uji hipotesis, yang akan membangkitkan data yang harus dipantau.

Fase keempat, 'Pemantauan' secara sistematis terhadap indikator-indikator kinerja sistem yang sensitif terhadap aksi. Pengumpulan data pemantauan ini dipakai untuk menguji apakah aksi yang dihipotesiskan dapat menghasilkan outcome yang diinginkan. Seberapa jauh tujuan bisa didekati dalam satu loop riset aksi disimpulkan pada fase ini, dan ditentukan apakah akan diperlukan loop riset aksi berikutnya dengan kembali melakukan fase 'Refleksi'.

\subsection{KASUS RISET AKSI PARTISIPATIF UNTUK PENCEGAHAN KEBAKARAN DAN RESTORASI GAMBUT DI KABUPATEN BENGKALIS, PROVINSI RIAU}

\subsubsection{Kebakaran dan restorasi gambut}

Lahan gambut tropis Indonesia merupakan salah satu penyumbang karbon terbesar, dengan kontribusi sebesar 57,5 gigaton karbon (Page dkk. 2011). Sekitar 43\% atau 6,4 juta ha dari lahan gambut Indonesia berada di Pulau Sumatra (Ritung dkk. 2011). Namun demikian, banyak dari lahan-lahan gambut ini telah rusak, yang menyebabkan rawan terjadi kebakaran dan kabut asap, terutama pada musim kemarau panjang. Beberapa penyebab kerusakan lahan gambut di Pulau Sumatra adalah konversi lahan- 


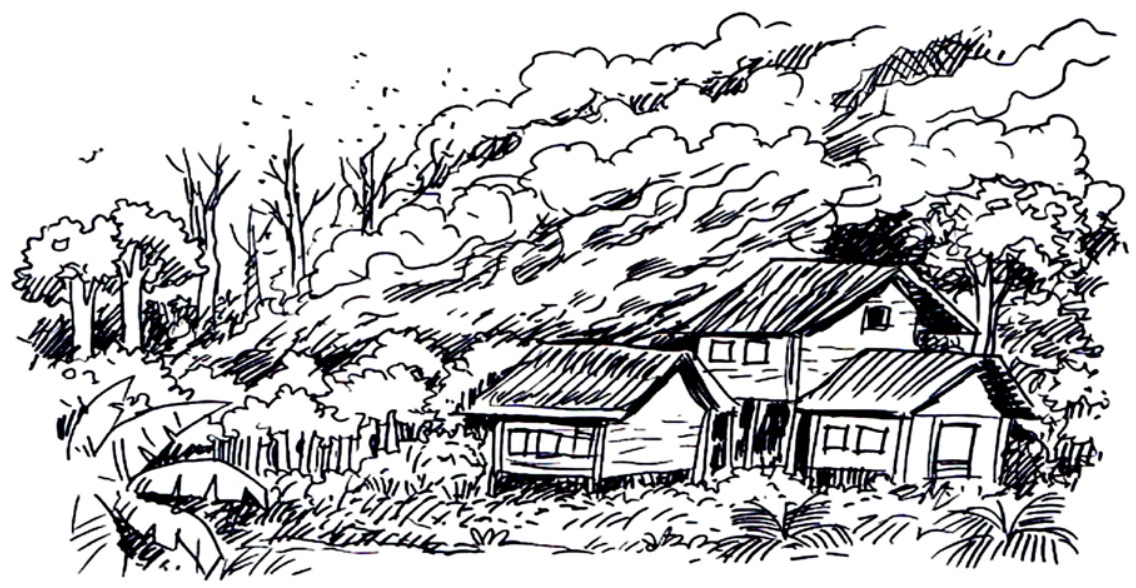

\section{Gambar 1.3 Kebakaran hutan dan lahan dalam skala besar menyebabkan kerugian finansial dan dampak-dampak yang secara langsung dirasakan oleh masyarakat.}

lahan gambut menjadi perkebunan (Miettinen dkk. 2016). Berdasarkan data KLHK,' pada tahun 2015 terjadi kebakaran hutan dan lahan pada 2,6 juta ha lahan di Indonesia. Dampak dari kebakaran hutan dan lahan ini mencapai 16,1 milyar dolar Amerika Serikat atau setara dengan 221 triliun rupiah (Glauber dkk. 2016). Selain itu, kebakaran hutan dan lahan ini juga menyebabkan meninggalnya 24 orang dan kematian dini pada 103.000 orang (Koplitz dkk. 2016). Emisi gas rumah kaca yang ditimbulkan diperkirakan mencapai 1,5 milyar mt CO 2 ekuivalen (Field dkk. 2016). Gambar 1.3 memberikan ilustrasi tentang kebakaran hutan.

Kebakaran hutan dan lahan dalam skala besar tersebut menjadi titik awal dari semakin intensifnya upaya-upaya pencegahan kebakaran dan restorasi gambut di Indonesia. Pada tahun 2016, Badan Restorasi Gambut (BRG) dibentuk melalui Peraturan Presiden RI No. 1 Tahun 2016, sebagai sebuah lembaga nonstruktural yang bertanggungjawab kepada Presiden. BRG menjalankan tugas koordinasi dan fasilitasi restorasi gambut pada tujuh provinsi prioritas restorasi di Indonesia, salah satunya di Provinsi Riau. Dengan mandat restorasi gambut seluas dua juta hektar, mengacu pada Perpres No. 1 Tahun 2016, BRG merumuskan dan mengimplementasikan rencana strategis dan program kerja. Arah kebijakan dan strategi utama BRG mencakup rewetting atau pembasahan kembali, revegetation atau penanaman kembali, dan revitalization of

1 http://sipongi.menlhk.go.id/hotspot/luas_kebakaran 
livelihood atau revitalisasi penghidupan masyarakat. Arah kebijakan dan strategi BRG memuat aspek-aspek lainnya yang lebih kompleks, termasuk penguatan kebijakan dan kelembagaan. Mandat dan arah kebijakan dan strategi ini mendasari terbentuknya program-program kerja, seperti Desa Peduli Gambut, Sosialisasi dan Edukasi Restorasi Gambut, yang mencakup Sekolah Lapang Petani Gambut dan berbagai pelatihan. Beberapa kegiatan lainnya yang sarat dengan peningkatan kesadartahuan masyarakat adalah Jambore Masyarakat Gambut, pelibatan berbagai pemuka agama dan program kamping generasi muda.

Upaya terkait lainnya adalah dirumuskannya Grand Design kebakaran hutan dan lahan pada tahun 2017. Grand Design ini memuat kerangka koordinasi pelaksanaan pengendalian kebakaran hutan, kebun, dan lahan yang perencanaan dan penganggarannya dikoordinasikan oleh Kementerian Perencanaan Pembangunan Nasional/Bappenas dan Kementerian Keuangan. Secara paralel, sejumlah kementerian/ lembaga, pemerintah daerah, TNI dan Polri, melaksanakan aksi pencegahan (dikoordinasikan oleh Kemenko Perekonomian), penanggulangan (dikoordinasikan oleh Menko Politik, Hukum dan Keamanan) dan pemulihan dan penanganan dampak (dikoordinasikan oleh Menko Pembangunan Manusia dan Kebudayaan). Upaya-upaya ini sesuai dengan Instruksi Presiden No. 11 Tahun 2015, dengan fokus utama pada aksi pencegahan.

Grand Design tersebut memuat hasil-hasil penelitian Saharjo (2003), Tacconi (2003), Syaufina (2008) dan Purnomo dkk. (2016) yang menyatakan bahwa kebakaran hutan dan lahan disebabkan oleh aktivitas manusia. Purnomo dkk. (2016) mengklasifikasikan tiga kelompok jaringan aktor korporasi, pemilik modal (cukong), dan individual yang terkait dengan kebakaran hutan, perkebunan, dan lahan di Indonesia. Mengingat hal tersebut, maka arah kebijakan dan strategi utama yang dirumuskan dalam rangka pencegahan kebakaran hutan, kebun, dan lahan memuat sejumlah aspek yang bersifat lintas sektoral, terpadu, dan komprehensif, dengan lima strategi utama, yaitu: 1) insentif dan disinsentif ekonomi, 2) penanganan pranata sosial, 3) penegakan hukum dan sinkronisasi peraturan dan perundangan, 4) pengembangan infrastruktur, dan 5) perkuatan pemadaman dini (early fire attack) (Medrilzam dkk. 2014).

Selain faktor iklim yang mendukung, adanya penegakan hukum dan upaya-upaya pencegahan kebakaran merupakan beberapa faktor pemungkin yang berkontribusi pada penurunan luas kebakaran. Berdasarkan data dari sistem pengawasan kebakaran hutan dan lahan KLHK (Sipongi), rata-rata luas kebakaran sepanjang tahun 2016 sampai 2018 menurun sebesar 86\% jika dibandingkan dengan kebakaran besar-besaran pada tahun 2015. Namun, pada tahun 2019 kebakaran hutan dan lahan kembali terjadi dan mencapai 857.755 hektar. Angka luas kebakaran pada tahun 2019 ini mengalami kenaikan sebesar 62\% dibandingkan dengan luas kebakaran pada tahun sebelumnya. Kondisi ini diperparah dengan adanya pemanasan global. Jika dibandingkan dengan 
tahun 1980, musim kebakaran semakin panjang pada seperempat bagian dunia yang tertutup vegetasi (Gray 2019). Selain itu, kejadian kebakaran juga akan semakin besar dengan iklim yang semakin hangat dan kering (De Groot dkk. 2013). Mengingat besar dan kompleksnya masalah pencegahan kebakaran dan restorasi gambut, maka diperlukan kerjasama sungguh-sungguh semua pihak, termasuk pemerintah, swasta, LSM, universitas dan lembaga penelitian nasional maupun internasional (Gambar 1.4). Kerja sama juga mendefinisikan nilai-nilai bersama untuk satu kemitraan yang lebih baik seperti didefinisikan oleh Arnstein (1969).

CIFOR bekerjasama dengan Pusat Studi Bencana Universitas Riau, pemerintah desa, dan kelompok-kelompok berbasis masyarakat melakukan riset aksi partisipatif pencegahan kebakaran dan restorasi gambut di Riau. Kerjasama ini didukung pendanaan dari Temasek Foundation (TF). RAP yang dilakukan memungkinkan pemahaman yang lebih baik antara masyarakat dengan ekosistem yang terdegradasi (Santana 2006). Pendekatan partisipatif ini juga memberikan kepastian komitmen jangka panjang pada program restorasi dan pengembangan pedesaan melalui pendekatan bottom-up, yang mengedepankan nilai-nilai demokratis jika dibandingkan dengan pendekatan topdown yang bersifat lebih otoriter (Global Institute for Sustainable Forestry 2006).

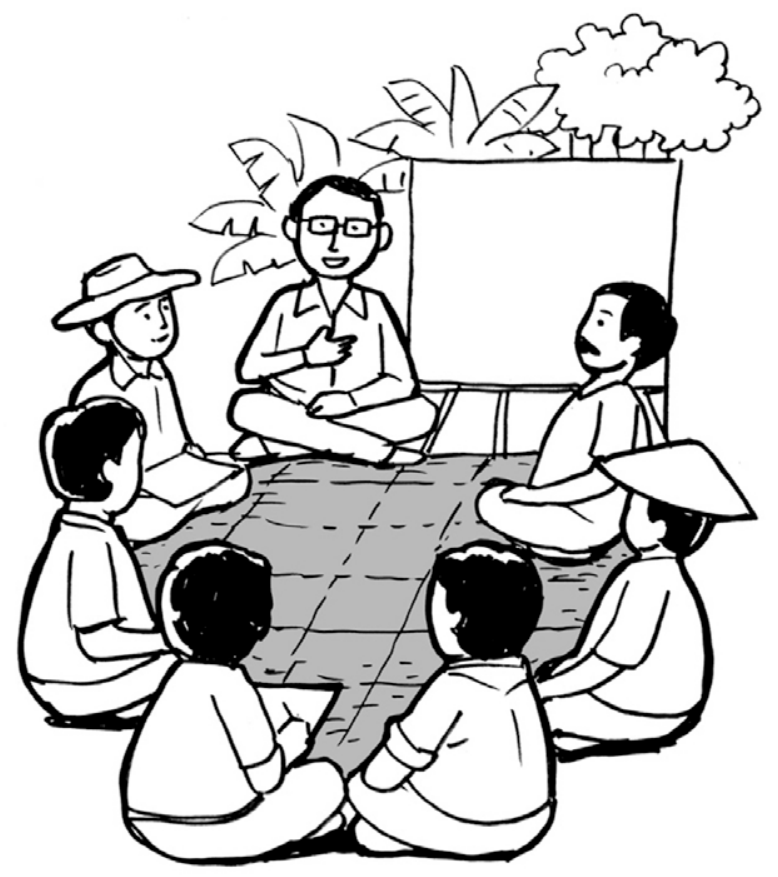

Gambar 1.4 Masyarakat adalah rekan peneliti dalam riset aksi partisipatif. 


\subsubsection{Pelaksanaan riset aksi partisipatif}

Riset aksi partisipatif dilaksanakan pada tahun 2018 - 2019 di Desa Dompas, Kecamatan Bukit Batu, Kabupaten Bengkalis, Provinsi Riau (Gambar 1.5). Uji coba lapangan difokuskan pada tujuh arena aksi seluas 11,1 ha (tidak termasuk Arena Aksi 7 yang berada di lahan pekarangan masyarakat). Diskusi dan diseminasi juga dilaksanakan di desa-desa satelit yaitu Desa Sukajadi, Buruk Bakul, Sungai Pakning, Sejangat, Pakning Asal, dan Tanjung Belit. Pelaksanaan kegiatan diskusi, diseminasi maupun uji coba lapangan dilakukan dalam kerangka riset aksi partisipatif, yang terdiri dari empat fase yaitu fase refleksi (reflection), perencanaan (planning), pemantauan (monitoring), dan aksi (action). Tujuan utama RAP di Desa Dompas adalah untuk mengurangi kebakaran dengan cara merestorasi gambut dan meningkatkan kesejahteraan masyarakat.

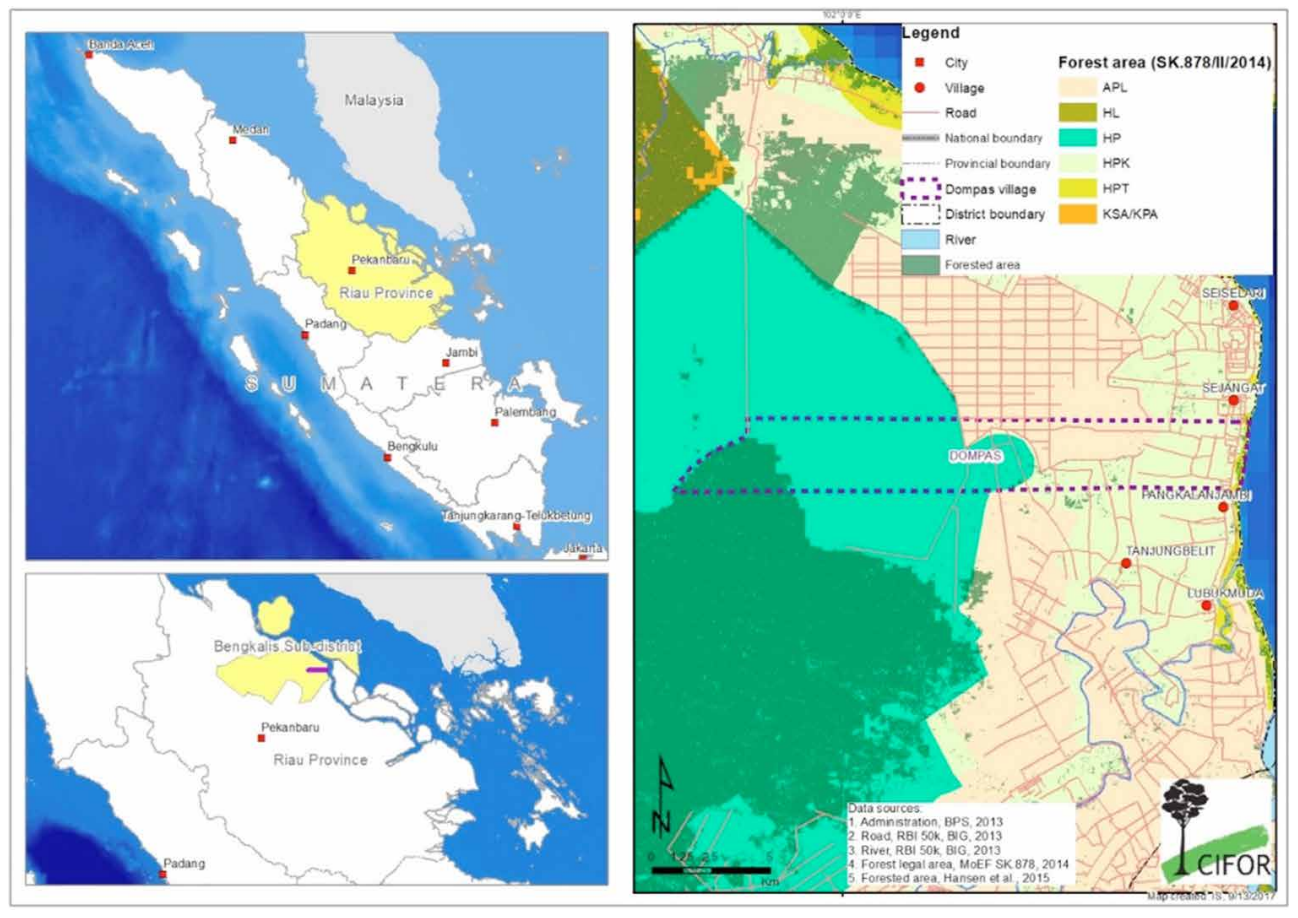

Gambar 1.5 Lokasi riset aksi partisipatif CIFOR dan PSB UNRI: Kabupaten Bengkalis, Provinsi Riau. 


\section{Fase refleksi (reflection)}

Fase refleksi bertujuan untuk mengidentifikasi dan memahami praktik-praktik terbaik dalam upaya pencegahan kebakaran dan restorasi gambut, termasuk mendokumentasikan data-data dasar. Pada fase ini dilaksanakan: identifikasi kondisi/ permasalahan yang terjadi melalui diskusi kelompok terfokus dan wawancara, dan pengkajian data dasar, yang meliputi survei rumah tangga pada desa intervensi dan desa-desa satelit sebagai kontrol dan survei institusi pada Masyarakat Peduli Api (MPA) dan pemerintah desa. Selain itu, pengkajian data dasar juga memuat hasil pengukuran kedalaman gambut untuk pembuatan peta dasar. Kegiatan lainnya yang dilaksanakan pada fase refleksi adalah pengkajian literatur dan diskusi kelompok terfokus, serta pengamatan lapangan dengan kelompok-kelompok masyarakat mengenai peluang bisnis di tingkat tapak (Gambar 1.6). Hasil dari fase refleksi ini adalah database data dasar, peta dasar kedalaman gambut dan hasil-hasil kajian dan diskusi; yang kemudian menjadi masukan untuk melaksanakan fase selanjutnya, yaitu fase perencanaan.

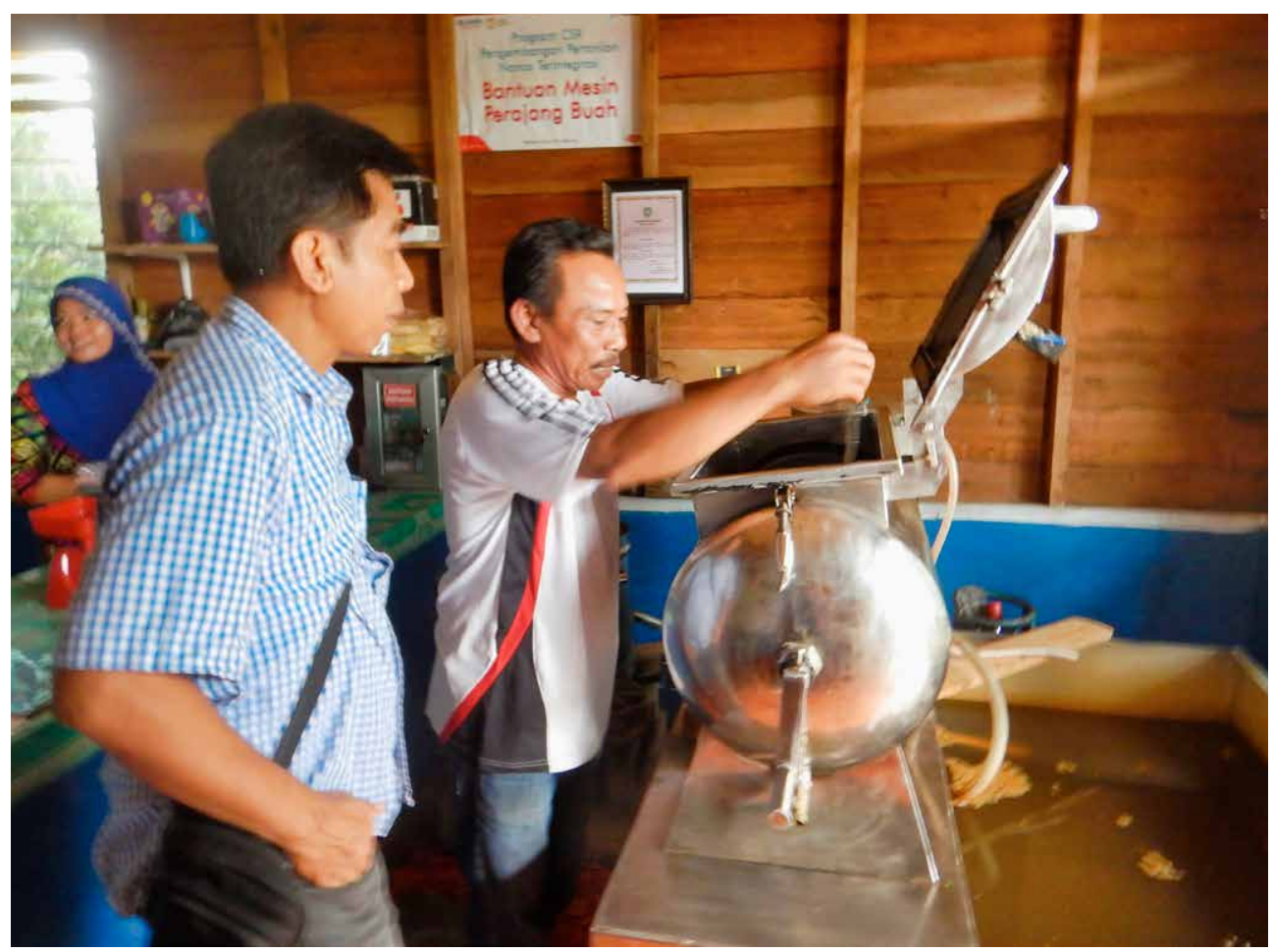

Gambar 1.6 Interaksi intensif antara peneliti dan masyarakat sebagai mitra peneliti menjadi bagian penting dalam pendekatan RAP. 
Hasil dari fase refleksi menunjukkan bahwa Desa Dompas adalah sebuah desa yang didominasi oleh masyarakat Melayu, yang terletak di bagian timur laut dari Pekanbaru. Desa ini memiliki berbagai jenis pohon yang berharga, misalnya meranti (Shorea spp.), ramin (Gonystylus spp.), suntai (Palaquium spp.), durian (Durio spp.), mentangor (Callophyllum spp.), dan medang (Cinamomum spp.), meskipun populasi dari jenisjenis ini mulai menurun. Berbagai macam jenis satwa, termasuk Owa-ungko (Hylobates agilis), siamang (Symphalangus syndactylus), lutung (Trachypithecus cristatus), kera ekor panjang (Macaca fascicularis), dan beruk (Macaca nemestrina), sering ditemukan di daerah hutan dan perkebunan. Beberapa jenis satwa yang dilindungi seperti harimau Sumatra (Panthera tigris sumatrae) dan beruang madu (Helarctos malayanus) juga dilaporkan berada di sekitar hutan dan perkebunan.

Berdasarkan fungsinya, mengacu pada Keputusan Menteri Lingkungan Hidup dan Kehutanan No: SK.878/Menhut-II/2014, Desa Dompas memiliki 1.129 ha area penggunaan lain (APL), 59 ha hutan lindung, 3.856 ha hutan produksi tetap, dan 1.682 ha hutan produksi konversi. Lanskap desa terdiri atas hutan-hutan primer dan sekunder, kebun campuran, perkebunan monokultur karet dan kelapa sawit, dan semak belukar atau lahan tidur bekas terbakar (Gambar 1.7). Berdasarkan hasil FGD yang dilakukan, kebun karet adalah salah satu sumber pendapatan prioritas bagi masyarakat lokal. Meskipun berukuran lebih kecil dibandingkan kebun kelapa sawit, pohon karet berada pada usia produktif, sehingga menghasilkan hasil panen yang lebih tinggi. Lanskap di desa ini juga didominasi dengan dua konsesi komersil skala besar yakni konsesi perkebunan kelapa sawit dan hutan tanaman industri akasia. Pendapatan signifikan untuk kebutuhan rumah tangga diperoleh oleh penduduk setempat dengan bekerja sebagai buruh di perkebunan sawit untuk membersihkan lahan dan sebagai pekerja perusahaan tambang. Peta penggunaan lahan di Desa Dompas ditunjukkan pada gambar berikut ini.

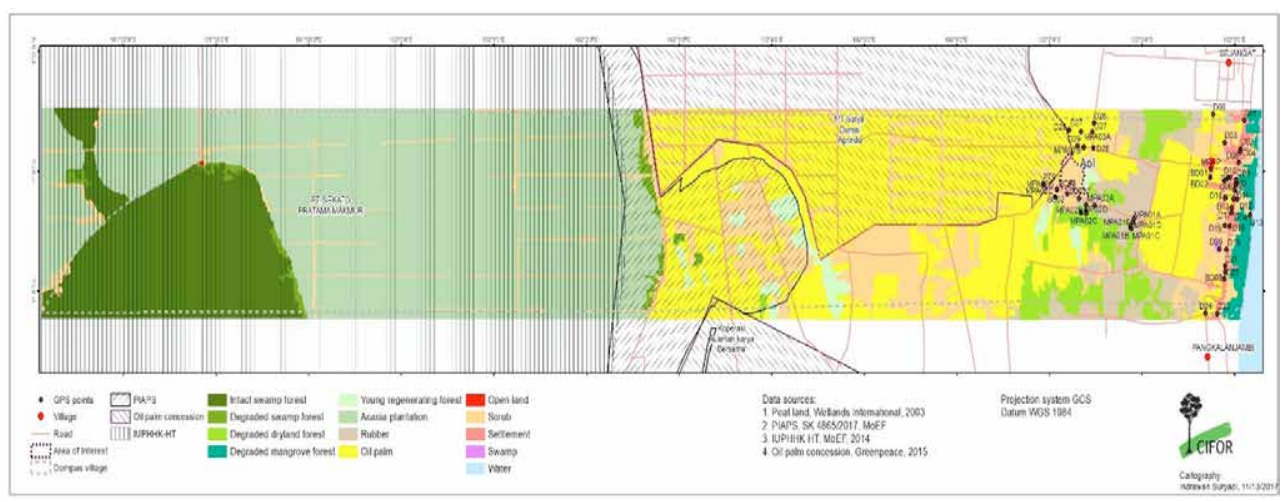

\section{Gambar 1.7 Peta penggunaan lahan di Desa Dompas, Kecamatan Bukit Batu, Kabupaten Bengkalis.}




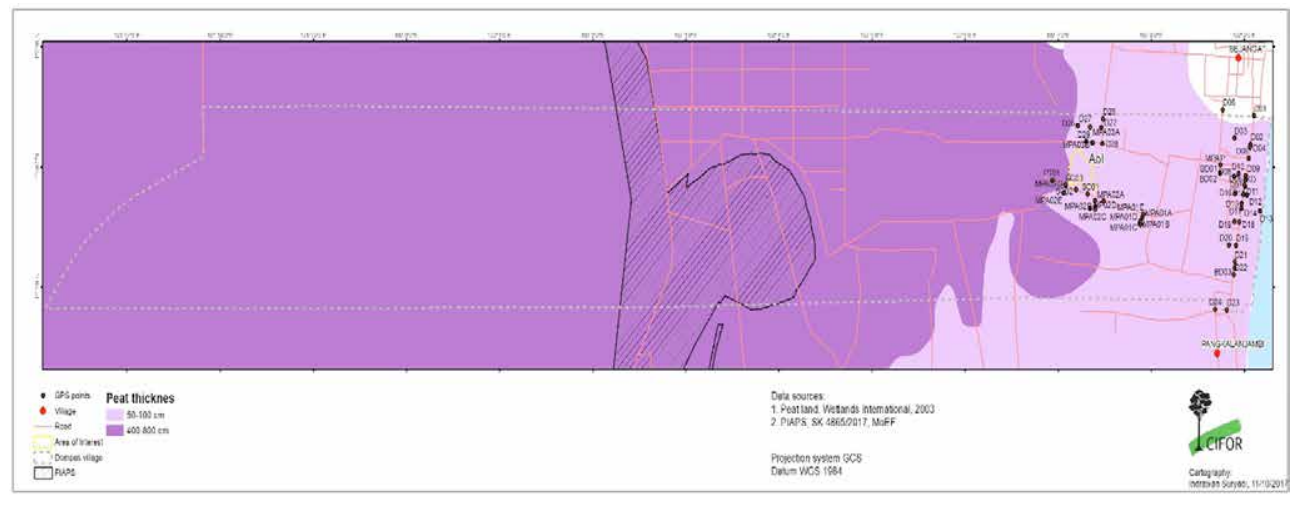

Gambar 1.8 Peta kedalaman gambut (Wahyunto dkk. 2003).

Berdasarkan peta lahan gambut dari Wahyunto dkk. (2003) yang ditunjukkan pada Gambar 1.8, lahan gambut yang berada di wilayah Desa Dompas dikategorikan sebagai gambut dengan kedalaman 50-100 cm (1.132 ha) dan 400-800 cm (5.594 ha). Hampir $70 \%$ dari gambut dalam $(400-800 \mathrm{~cm})$ terletak di hutan produksi tetap. Wilayah perumahan dan perkebunan petani skala kecil diperkirakan berada pada gambut dangkal dengan kedalaman $50-100 \mathrm{~cm}$. Namun demikian, hasil pemetaan gambut yang dilakukan CIFOR dalam RAP ini menunjukkan bahwa beberapa sampel perkebunan petani skala kecil ini berada pada gambut dalam dengan kedalaman lebih dari $400 \mathrm{~cm}$. Berbagai aktivitas manusia yang intensif pada lahan gambut dalam ini meningkatkan urgensi untuk memitigasi risiko degradasi dan kebakaran pada lahan gambut.

Pemetaan partisipatif dilakukan bersama dengan masyarakat Desa Dompas untuk mengidentifikasi wilayah-wilayah yang terdampak kebakaran. Berdasarkan informasi dari masyarakat, sebagian besar wilayah Desa Dompas terkena dampak kebakaran hutan dan lahan. Lebih dari separuh rumah tangga (57\%) di Desa Dompas menyatakan bahwa kebakaran hutan dan lahan pada tahun 2017 terjadi di lahan mereka. Hampir separuh dari rumah tangga (46\%) menyatakan bahwa lahan mereka berisiko tinggi dan sangat tinggi untuk terbakar, namun sebagian besar dari mereka tidak sadar akan penyebab-penyebab kebakaran hutan dan lahan tersebut.

Demand atau permintaan masyarakat akan RAP juga nyata. Masyarakat melihat bahwa RAP bisa memberikan pengetahuan, pengalaman dan perubahan penghidupan lewat praktik-praktik yang lebih ramah lingkungan. RAP juga mengakomodasi usulan-usulan dari masyarakat, tokoh-tokoh masyarakat, termasuk kepala desa dan aparatnya, serta para pemuka masyarakat. 


\section{Fase perencanaan (planning)}

Fase perencanaan bertujuan untuk mengembangkan rencana aksi, termasuk pembagian peran dan tanggungjawab maupun biaya dan manfaat (Gambar 1.9). Fase ini banyak menggunakan metode diskusi kelompok terfokus dengan tematema spesifik sebagai berikut: model bisnis, pembagian peran dan tanggungjawab, pembagian biaya dan manfaat, dan perumusan rencana aksi. Fase ini menghasilkan kesepakatan pengelolaan arena aksi, yaitu: Masyarakat Peduli Api (MPA) mengelola lahan milik desa (lahan publik) seluas 2,2 ha, yang selanjutnya disebut sebagai Arena Aksi 1. Pada lahan ini MPA merumuskan model bisnis penanaman mohon multiguna dan ekowisata pemancingan. Kelompok wanita dan kelompok tani pria masing-masing mengelola lahan co-management seluas 3,3 ha dan 3,2 ha, yang selanjutnya disebut sebagai Arena Aksi 2 dan 3. Pada arena aksi ini, kelompok wanita dan kelompok tani pria merencanakan model bisnis wanatani nanas dan pohon multiguna. Kelompok keluarga petani yang mengelola lahan pribadi dengan luas total dua hektar merumuskan model bisnis wanatani kopi liberika dan karet, yang selanjutnya disebut sebagai Arena Aksi 4, 5, dan 6. Terakhir, pada Arena Aksi 7 yang berada di lahan pekarangan warga Desa Dompas, lebih dari 300 rumah tangga Desa Dompas akan menanam kelapa hibrida di lahan pekarangannya.

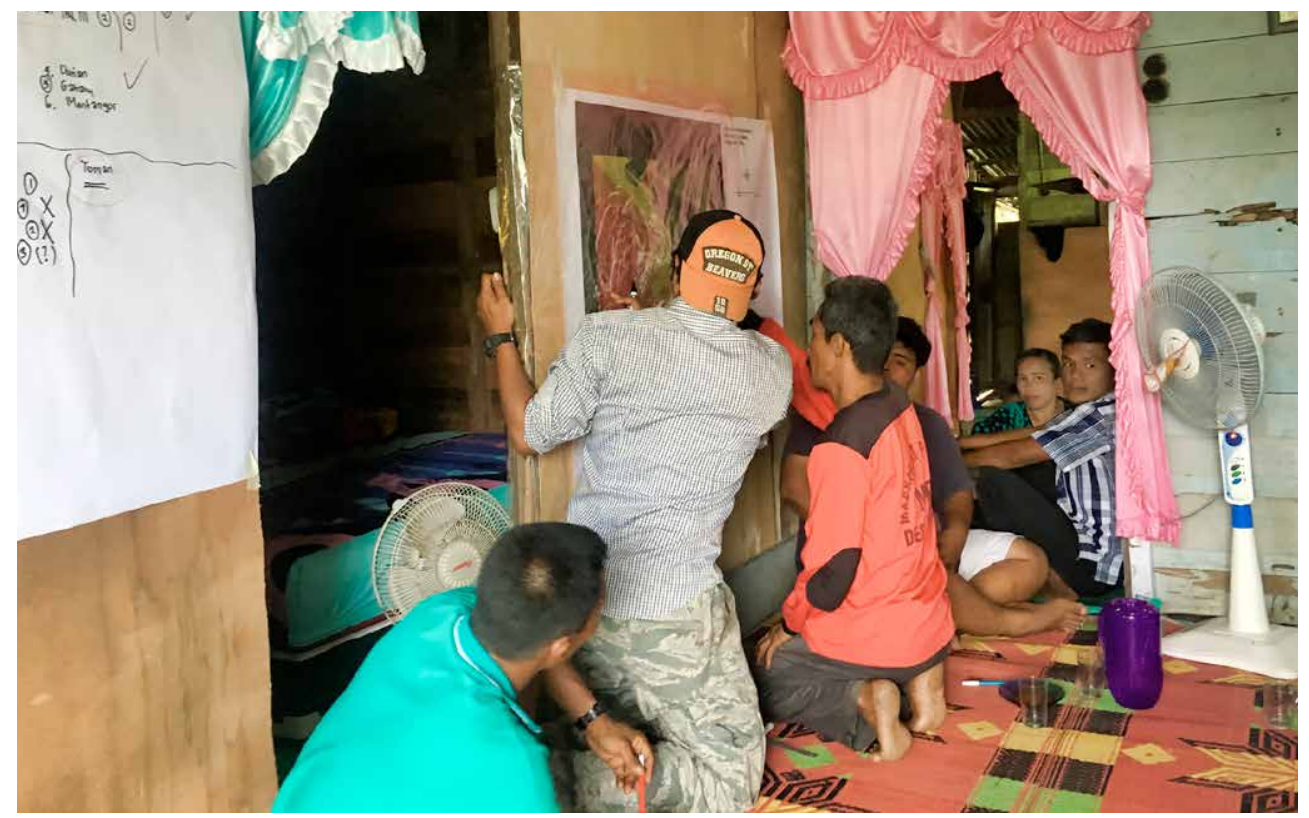

Gambar 1.9 Salah satu elemen penting dalam perencanaan aksi adalah penyadartahuan masyarakat akan kondisi ekologi dan peluang bisnis. 


\section{Fase aksi (action)}

Fase aksi bertujuan untuk mengimplementasikan rencana aksi yang telah dirumuskan pada fase perencanaan (Gambar 1.10). Beberapa kegiatan yang telah dilaksanakan di sejumlah arena aksi adalah:1) rewetting (pembasahan kembali) melalui pembangunan dan perbaikan sekat kanal, 2) revegetasi (penanaman kembali) melalui pelatihan budidaya dan pembuatan rumah pembibitan, pembukaan lahan tanpa bakar, penanaman pohon dan komoditas yang telah disepakati, 3) revitalisasi penghidupan masyarakat melalui implementasi model bisnis berbasis barang dan jasa yang telah disepakati, 4) penguatan kelembagaan melalui pembentukan Kelompok Tani Hutan (KTH) dan fasilitasi serta penguatan kelompok pengelola arena aksi maupun kelompok MPA. Selain itu, dukungan untuk patroli kebakaran hutan dan lahan di Desa Dompas, maupun dukungan pemadaman kebakaran hutan dan lahan di desa-desa satelit telah diberikan.

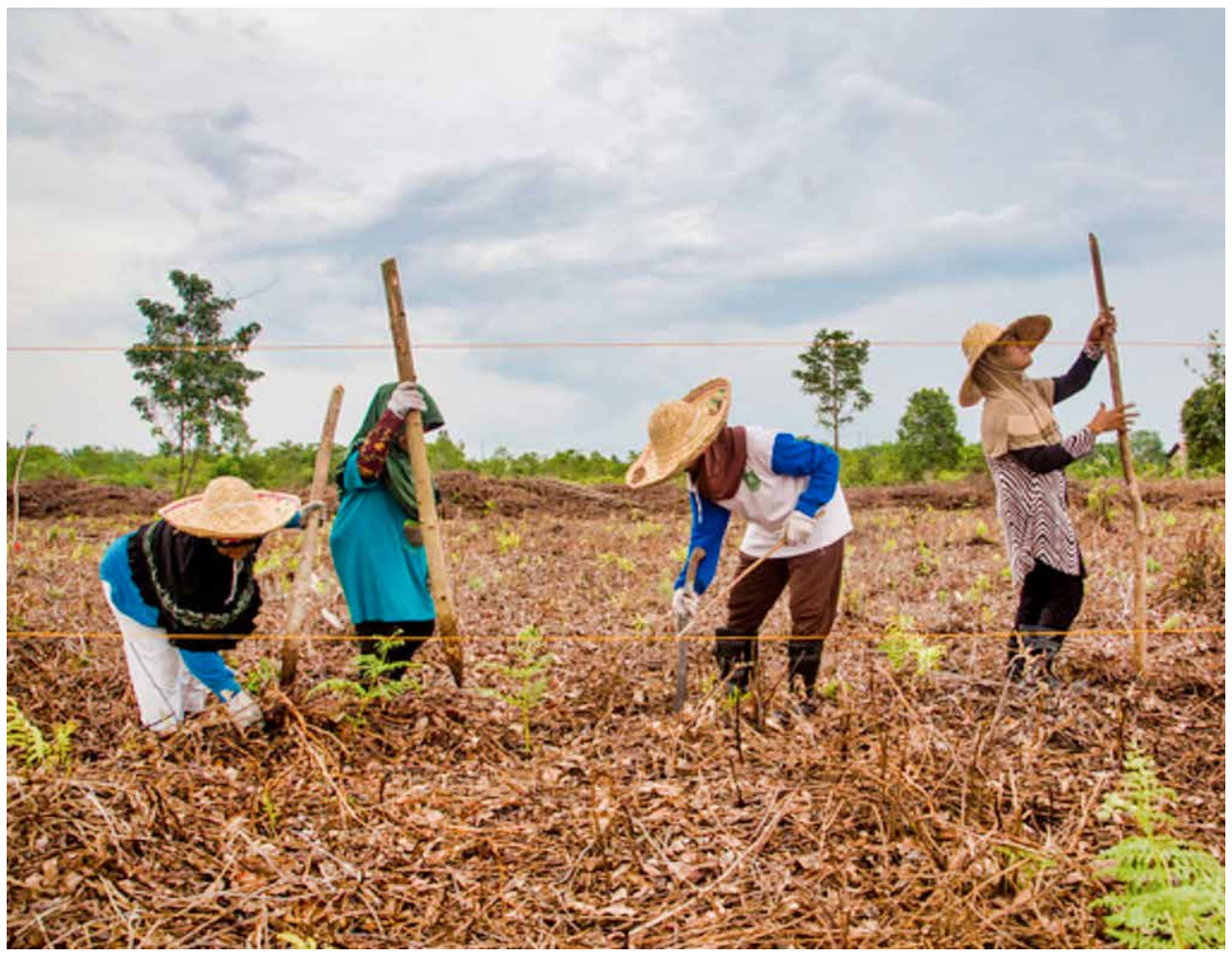

Gambar 1.10 Aksi di lapangan pada skala bisnis yang nyata (wanatani nanas). 


\section{Fase pemantauan (monitoring)}

Fase pemantauan bertujuan untuk memantau keluaran dan dampak jangka menengah dan jangka panjang. Pada fase ini, alat-alat pemantauan, misalnya alat untuk pengukuran tinggi muka air tanah dan kode bar untuk inventarisasi tanaman, telah dipasang (Gambar 1.11). Sistem pemantauan secara online telah dibuat dan dapat diakses melalui website proyek: https://cifor.org/CBFPR untuk memantau tinggi muka air pada arena-arena aksi yang disekat dan pada area kontrol (tidak disekat), dan juga untuk mengetahui jumlah tanaman yang telah ditanam dan tingkat kelangsungan hidupnya. Pemantauan dan pengumpulan data, termasuk perubahan sosial dan ekonomi, dilaksanakan secara partisipatif bersama dengan masyarakat Desa Dompas.

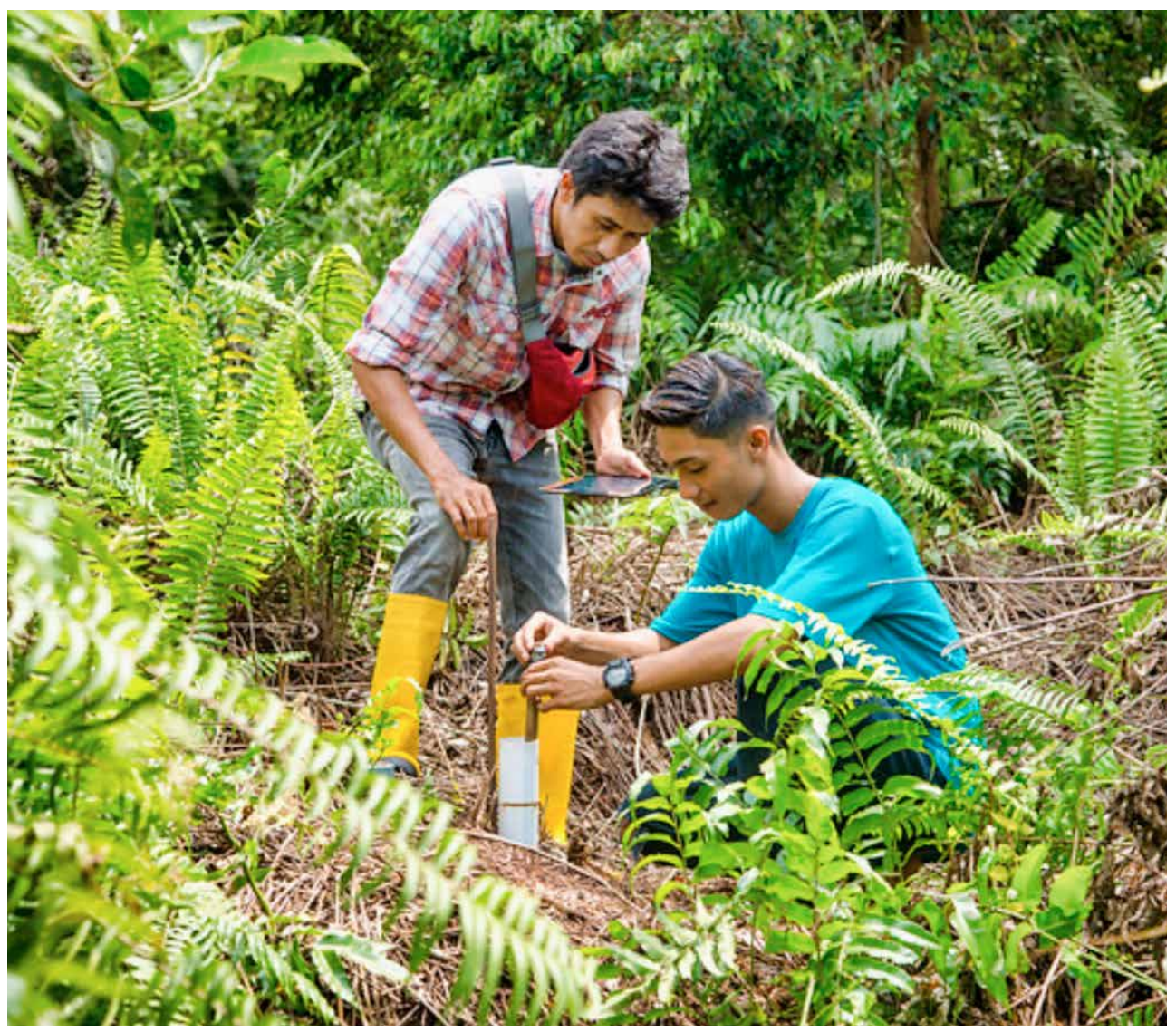

Gambar 1.11. Aksi yang telah dijalankan perlu dipantau secara partisipatif bersama dengan masyarakat. 


\subsection{PEMBELAJARAN UNTUK PERCEPATAN PENCEGAHAN KEBAKARAN DAN RESTORASI GAMBUT}

Dibandingkan dengan riset konvensional maka RAP mempunyai kelebihan yang dapat dipakai untuk mempercepat pencegahan kebakaran dan restorasi gambut, yaitu:

1. RAP merupakan perwujudan dari transdisiplin, yang mengintegrasikan berbagai disiplin (multidisiplin dan interdisiplin) dan kearifan lokal dan global (local and global wisdoms).

2. RAP adalah cara yang efektif bagi peneliti untuk terlibat secara aktif dalam pencegahan kebakaran dan restorasi gambut.

3. RAP secara ilmiah bisa dipertanggungjawabkan (scientifically sound) dan dapat membuat perubahan di lapangan secara lebih cepat. RAP menghasilkan publikasi ilmiah di jurnal-jurnal yang bermutu, dengan kualitas yang sebanding dengan risetriset konvensional.

4. RAP bersifat intensif sehingga riset harus berfokus pada masalah, tingkatan dan wilayah tertentu.

5. RAP menghasilkan outcome dalam jangka riset tersebut, adapun outcome dari riset konvensional berpotensi terjadi di luar waktu riset. Anggota masyarakat yang terlibat dalam RAP melihat dan mengalami sendiri pembuatan model bisnis, mengerjakan dan memantau nenas, pepohonan atau kolam ikan.

6. RAP membutuhkan waktu yang lebih lama dibandingkan dengan riset konvensional yang umumnya berkisar pada pengumpulan data, analisis dan publikasi. RAP membutuhkan lebih dari sekedar pengumpulan data, melainkan juga pendampingan dan fasilitasi masyarakat agar mereka dapat menjadi elemen kunci. Idealnya RAP dilakukan dalam jangka waktu tiga tahun atau lebih.

7. RAP sering lebih disukai oleh donor karena dampak riset dapat segera terlihat sehingga donor bisa mengklaim bahwa perubahan-perubahan telah terjadi di lapangan.

\subsection{PENUTUP}

Pemerintah, masyarakat dan donor menginginkan riset yang membawa perubahan. Kebutuhan akan perubahan sangat tinggi, sehingga sudah saatnya riset tidak hanya menghasilkan laporan dan publikasi, namun juga menghasilkan outcome dan dampak yang nyata. Riset yang dilakukan dengan partisipasi penuh dan berorientasi pada aksi menjadi jawabannya. RAP dirancang untuk membawa perubahan nyata di lapangan. 
RAP memperkaya bentuk pendekatan riset di bidang pengelolaan sumber daya alam dan lingkungan, seperti pencegahan kebakaran dan restorasi gambut. Restorasi gambut harus dipahami sebagai upaya bersama para pihak dalam perbaikan tata kelola air dan tata kelola ekosistem gambut secara berkelanjutan pada satu kesatuan hidrologisnya (KHG). Hal mendasar sebagaimana amanat PP 57 tahun 2016, terkait penetapan zona untuk fungsi budidaya dan fungsi lindung. Pada kedua fungsi ini, restorasi gambut ditargetkan untuk tujuan tata air pada fungsi budidaya dan konservasi air pada fungsi lindung. Walaupun RAP umumnya membutuhkan biaya dan waktu yang lebih besar dibandingkan riset konvensional, namun outcome dan dampak dari RAP akan lebih cepat terasakan. RAP juga membutuhkan intesintas interaksi yang tinggi dengan masyarakat, pengambil kebijakan dan dunia bisnis. Ketika perubahan yang membawa perbaikan betul-betul diinginkan, maka semua hal tersebut menjadi harga yang harus dibayar.

\subsection{PUSTAKA}

Arnstein SR. 1969. A Ladder of Citizen Participation. Journal of the American Planning Association, 35(4): 216-224.

Boltanski L dan Thévenot L. 2006. On Justification: Economies of Worth. Princeton: Princeton University Press.

Colfer CJP. 2005. The Complex Forest: Communities, Uncertainty, and Adaptive Collaborative Management, Washington DC: Resources for the Future; Bogor, Indonesia: Center for International Forestry Research (CIFOR).

De Groot RS, Blignaut J, Van Der Ploeg S, Aronson J, Elmqvist T, dan Farley J. 2013. Benefits of investing in ecosystem restoration. Conservation Biology, 27(6): 1286-1293.

FAO. 2019. The State of Food Insecurity in the World 2013. The multiple dimensions of food security. Rome: FAO. [diakses 15 November 2019] http://www.fao.org/3/ ca5162en/ca5162en.pdf

FAO. 2016. Global Forest Resources Assessment 2015: How are the world's forests changing? 2nd edition. Rome: FAO. [diakses 10 Januari 2017]. http://www.fao.org/3/ a-i4793e.pdf

Glauber AJ, Moyer S, Adriani M, dan Gunawan I. 2016. The cost of fire: An economic analysis of Indonesia's 2015 fire crisis. Jakarta: World Bank.

Global Institute of Sustainable Forestry. 2006. Issue introduction. YFF Review, 9 (2): 1113. New Haven, Connecticut: Global Institute of Sustainable Forestry.

Gray E. 2019. Satellite data record shows climate change's impact on fires. [diakses 15 November 2019]. https://climate.nasa.gov/news/2912/satellite-data-record-showsclimate-changes-impact-on-fires/ 
Habermas J. 1968. Theory and Practice, diterjemahkan oleh John Viersel. London: Heinemann.

Habermas J. 1987. The Theory of Communicative Action. Volume 1: Reason and the Rationalization of Society, diterjemahkan oleh T. McCarthy. Cambridge: Polity Press.

Henocque Y dan Denis J, eds. 2001. A methodological guide: Steps and tools towards integrated coastal area management (Intergovernmental Oceanographic Commission Manuals and Guides No. 42). Paris: United Nations Educational, Scientific and Cultural Organization.

Koplitz SN, Mickley LJ, Marlier ME, Buonocore JJ, Kim PS, Liu T, Sulprizio MP, De Fries, RS, Jacob DJ, Schwartz, J., Pongsiri M, dan Myers SS. 2016. Public health impacts of the severe haze in Equatorial Asia in September-October 2015: demonstration of a new framework for informing fire management strategies to reduce downwind smoke exposure, Environmental Research Letters, 11(9): 094023.

Kusumanto T, Yuliani L, Macoun P, Indriatmoko Y, dan Adnan H. 2005. Learning to adapt: managing forests together in Indonesia. Bogor, Indonesia: Center for International Forestry Research (CIFOR).

Medrilzam M, Dargusch P, Herbohn J, dan Smith C. 2014. The socio-ecological drivers of forest degradation in part of the tropical peatlands of Central Kalimantan, Indonesia. Forestry: An International Journal of Forestry Research, 87(2): 335-345.

Miettinen J, Shi J, dan Liew SC. 2016. Land cover distribution in the peatlands of Peninsular Malaysia, Sumatra and Borneo in 2015 with changes since 1990. Global Ecology and Conservation, 6: 67-78.

Ossowski S. 1999. Co-ordination in artificial agent societies. New York: Springer-Verlag.

Ostrom E. 2007. Sustainable social-ecological systems: an impossibility. Presented at the 2007 Annual Meetings of the American Association for the Advancement of Science, Science and Technology for Sustainable Well-Being, 15-19 February in San Francisco and Proceedings of the National Academy of Sciences (USA).

Ostrom E. 2010. The Institutional Analysis and Development Framework and the Commons. Cornell Law Review, 95(4): 807-815.

Page SE, Rieley JO, dan Banks CJ. 2011. Global and regional importance of the tropical peatland carbon pool. Global Change Biology, 17(2): 798-818.

Pruzan P. 1994. Etik, ærdibaseret ledelse og Det EtiskeRegnskab, Dalam Gamborg C. 2002. The acceptability of forest management practices: an analysis of ethical accounting and the ethical matrix. Forest Policy and Economics, 4: 175-186.

Purnomo H, Achdiawan R, Shantiko B, Amin SM, Irawati RH, Melati, dan Wardell DA. 2016. Multi-stakeholder processes to strengthen policies for small and medium-scale forestry enterprises in Indonesia. International Forestry Review, 18(4): 485-501.

Purnomo H, Achdiawan R, Melati, Irawati RH, Sulthon, Shantiko B, dan Wardell A. 2014a. Value-chain dynamics: strengthening the institution of small-scale furniture producers to improve their value addition. Forests, Trees and Livelihoods, 23(1-2): 87-101. 
Purnomo H, Guizol P, dan Mendoza GA. 2009a. Exploring Partnerships between Local Communities and Timber Companies: An Experiment Using the Role-Playing Games Approach. International Journal of Forestry Research. Article ID 451362, 13 pages http://downloads.hindawi.com/journals/ijfr/2009/451362.pdf (online journal)

Purnomo H, Guizol P, Awang SA, Wardhana W, Irawati RH, dan Rennaldi D. 2014b. Communicative action to level the playing field in forest plantations in Indonesia. Journal of Sustainable Forestry, 33(4): 337-357.

Purnomo H, Guizol P, dan Muhtaman DR. 2009b. Governing the teak furniture business: A global value chain system dynamic modeling approach. Environmental modelling and software, 24 (12): 1391-1401.

Purnomo H, Irawati RH, Fauzan AU, dan Melati. 2011. Scenario-based Actions to Upgrade Small-scale Furniture Producers and their Impacts on Women in Central Java, Indonesia. International Forestry Review, 13(2): 152-162

Purnomo H, Okarda B, Shantiko B, Achdiawan R, Dermawan A, Kartodihardjo H, dan Dewayani AA. 2019. Forest and land fires, toxic haze and local politics in Indonesia. International Forestry Review, 21 (4): 1-15.

Purnomo H, Shantiko B, Sitorus S, Gunawan H, Achdiawan R, Kartodihardjo H, dan Dewayani AA. 2017a. Fire economy and actor network of forest and land fires in Indonesia. Forest Policy and Economics, 78: 21-31.

Purnomo H, Shantiko B, Wardell DA, Irawati RH, Pradana NI, dan Yovi EY. 2017b. Learning Landscape Sustainability and Development Links. International Forestry Review, 19(3): 333-349.

Reason P dan Torbet WR. 2001.The Action Turn: Toward a Transformational Social Science. Concept and Transformation, 6 (1): 1-37.

Reason P dan McArdle K. 2004. Brief Notes on the Theory and Practice of Action, Dalam S. Becker dan A. Bryman, eds. Understanding Research Methods for Social Policy and Practice. London: Policy Press.

Ritung S, Wahyunto, Nugroho K, Sukarman, Hikmatullah, Suparto dan Tafakresnanto C. 2011. Peta Lahan Gambut Indonesia Skala 1:250.000. Bogor, Indonesia: Balai Besar Penelitian dan Pengembangan Sumberdaya Lahan Pertanian.

Röling N dan van de Fliert E. 1994. Transforming extension for sustainable agriculture: The case of integrated pest management in rice in Indonesia. Agriculture and Human Values, 11 (2-3): 96-108.

Saharjo BH. 2003. Kebakaran Hutan dan Lahan. Bogor, Indonesia: Laboratorium Kebakaran Hutan dan Lahan, Fakultas Kehutanan, Institut Pertanian Bogor.

Saidi A. 2015. Pembagian epistemiologi Habermas dan implikasinya terhadap metodologi penelitian sosial-budaya. Jurnal Masyarakat \& Budaya 15 (2): 111-128.

Santana MRA. 2006. Community participation in forest restoration. YFF Review, 9 (2): 11-13. New Haven, Connecticut: Global Institute of Sustainable Forestry. 
Selener D. 1997. Participatory Action Research and Social Change. Ithaca NY: Cornell Participatory Action Research Network, Cornell University.

Syaufina L. 2008. Kebakaran Hutan dan Lahan di Indonesia: Perilaku Api, Penyebab dan Dampak Kebakaran. Malang, Indonesia: Banyu Media Publishing.

Tacconi L. 2003. Kebakaran hutan di Indonesia: penyebab, biaya dan implikasi kebijakan. CIFOR Occasional Paper no. 38 (i). Bogor, Indonesia: Center for International Forestry Research (CIFOR).

Wahyunto, Ritung S, Subagjo H. 2003. Maps of area of peatland distribution and carbon content in Sumatra 1990-2002. Bogor, Indonesia: Wetlands International Indonesia Programme \& Wildlife Habitat Canada.

World Bank. 2012. New Report Examines Risks of 4 Degree Hotter World by End of Century. [diakses 9 Agustus 2017]. http://www.worldbank.org/en/news/pressrelease/2012/11/18/new-report-examines-risks-of-degree-hotter-world-by-end-ofcentury 



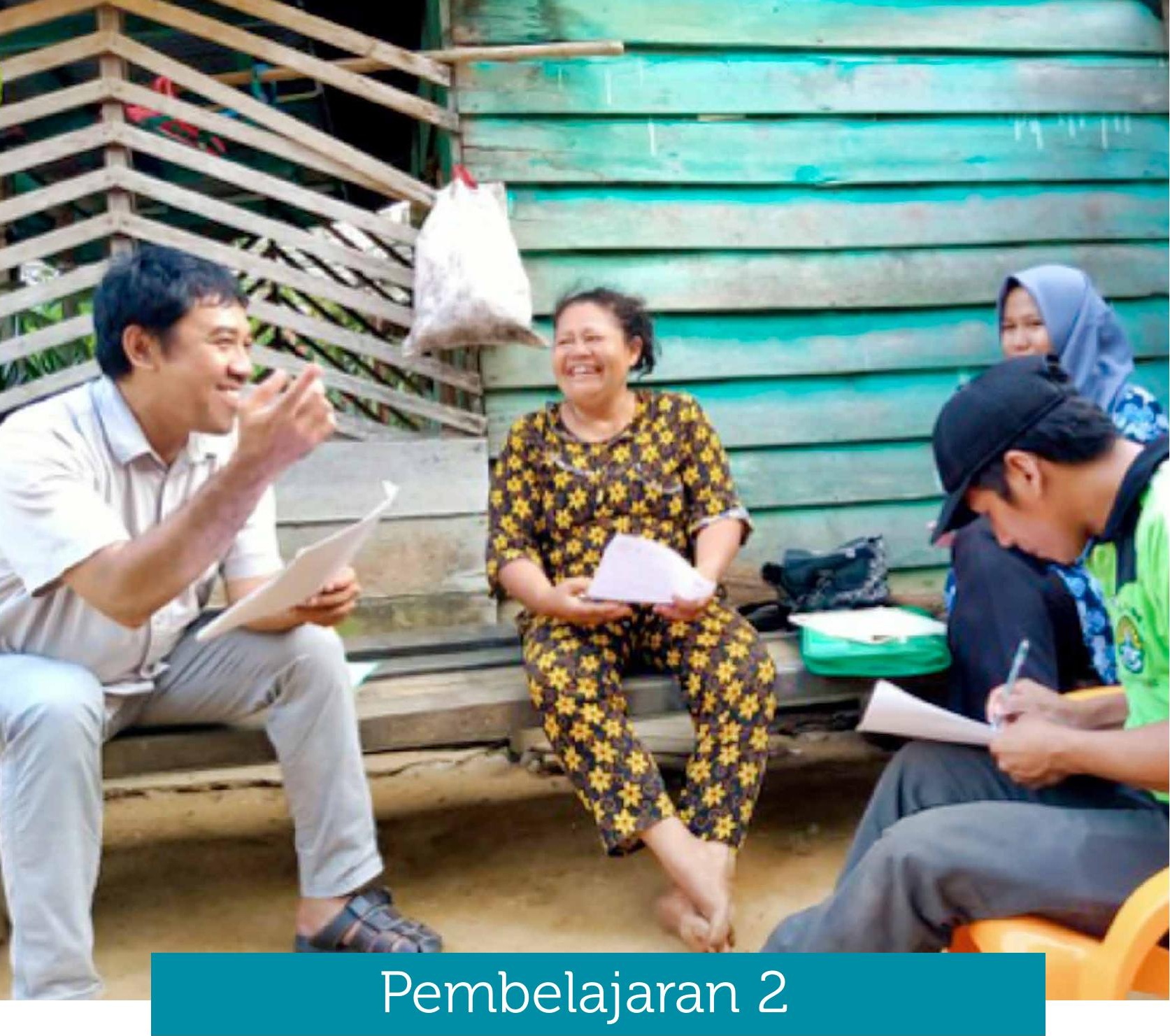

Perubahan Perilaku Pembakaran dan Pencegahan Kebakaran di Riau

Murni Po, Daniel Mendham, John Gardner, Eko Hardiyanto, M. Gunawan Wibisono dan Muhammad Mardhiansyah 


\subsection{RANGKUMAN}

Perubahan perilaku pembakaran dan pencegahan kebakaran merupakan bagian penting dari upaya untuk mengurangi kebakaran dan kabut asap di Indonesia. Pencegahan kebakaran menuntut perubahan cara berpikir (mindset), norma dan praktik-praktik oleh masyarakat dan para petani, untuk memastikan keberlanjutan dan untuk menanamkan perilaku 'tanpa bakar' ke dalam kehidupan sehari-hari anggota masyarakat. Dua riset telah dilakukan untuk memahami perilaku pembakaran dan tanpa pembakaran dari sejumlah petani yang tinggal di Provinsi Riau. Kami mendapatkan bahwa para petani yang tinggal di wilayah tersebut cenderung tidak lagi melakukan pembakaran lahan, yang hal ini merupakan suatu perubahan yang signifikan dibandingkan dua tahun sebelumnya, ketika sekitar 50\% petani masih melakukan pembakaran (Rohadi 2017). Kondisi ini menunjukkan secara jelas bahwa para petani telah merasa ikut bertanggung jawab, sama halnya dengan pihak pemerintah dan perusahaan-perusahaan kehutanan setempat, dalam mencegah kebakaran lahan gambut. Adanya Instruksi Presiden tentang pelarangan pembakaran, yang diikuti penegakannya secara tegas oleh pemerintah dan militer, telah menjadi faktor utama yang mempengaruhi perilaku masyarakat, sehingga saat ini perilaku tanpa pembakaran menjadi suatu norma. Para petani telah menerima praktik-praktik pengelolaan lahan tanpa bakar dan beranggapan bahwa hampir semua orang telah menerapkan praktik-praktik tanpa bakar untuk mengelola lahan mereka. Mereka juga merasa bahwa mereka mampu mengelola lahan tanpa pembakaran dan mereka telah memiliki dukungan yang diperlukan untuk secara mandiri mengelola lahan tanpa pembakaran. Namun demikian, para petani yang terlibat dalam riset ini nampaknya belum menginternalisasi nilai-nilai intrinsik dari penerapan praktik-praktik pengelolaan lahan tanpa bakar untuk mengelola lahan mereka, sebagaimana diindikasikan oleh nilai Indeks Otonomi Relatif (Relative Autonomy Index/RAl). Hal ini berarti bahwa pembakaran masih akan menjadi metode pengelolaan lahan yang bisa mereka lakukan, apabila mereka tetap dapat melakukannya tanpa adanya sanksi hukuman. Bagi para petani, kegunaan metode pembakaran masih dianggap jauh lebih praktis dibandingkan dengan alternatif lain, yaitu untuk pembersihan lahan, menghemat tenaga kerja, memudahkan proses penanaman, meminimalkan penyakit dan meningkatkan kesuburan tanah. Para petani dalam riset ini juga secara jelas mengindikasikan bahwa mereka akan kembali ke metode pembakaran jika Instruksi Presiden terkait larangan pembakaran tersebut dicabut.

Praktik-praktik alternatif tanpa pembakaran membutuhkan tenaga kerja dan sumber daya keuangan yang jauh lebih besar dibandingkan pembakaran, dan sebagian petani tidak mampu menanggung biaya-biaya tersebut. Sejak larangan pembakaran secara ketat diterapkan, para petani dipaksa untuk membekali diri mereka dengan pengetahuan dan keterampilan yang baru, serta tenaga kerja dan biaya terkait peralatan/mesin, bahan kimia dan pupuk yang lebih tinggi, untuk dapat mencukupi kebutuhan hidup mereka. Para petani dalam riset ini sering meminta dukungan untuk membantu mereka 
mengelola lahan tanpa pembakaran. Dukungan dalam bentuk peralatan/mesin, pupuk dan bahan kimia untuk mengendalikan gulma sangat penting bagi petani, demikian juga informasi tentang bagaimana mengelola lahan tanpa pembakaran. Lebih dari setengah peserta menginginkan akses terhadap penggunaan alat berat. Mesin-mesin dengan kapasitas dan ukuran yang kecil kemungkinan akan lebih efektif dibandingkan penggunaan alat berat - yaitu dapat membantu petani agar terampil membersihkan lahan dan meningkatkan kemandirian mereka.

Petani miskin terdampak secara lebih parah dengan keharusan mengadopsi praktikpraktik tanpa pembakaran. Oleh karena itu, program-program pencegahan kebakaran yang dapat membantu penduduk desa untuk beradaptasi mengelola lahan tanpa pembakaran, seperti Program Desa Bebas Api, yang program ini penting untuk membantu penduduk desa melewati masa transisi dari pembakaran menuju tanpa pembakaran di masa depan. Program-program yang dapat meningkatkan keterampilan petani dan membantu mereka agar dapat secara mandiri mengelola lahan tanpa pembakaran merupakan pelengkap yang sangat penting bagi kebijakan larangan pembakaran. Selain itu, Masyarakat Peduli Api (MPA), yaitu program sukarelawan pemadam kebakaran dari pemerintah pusat, disikapi dengan tingkat kesadaran yang tinggi dan dianggap bermanfaat bagi para petani. Sejumlah petani menyampaikan bahwa api seringkali dapat dipadamkan dengan sangat cepat ketika terjadi kebakaran. Program-program pencegahan kebakaran yang dimiliki oleh industri berbasis hutan secara signifikan lebih dikenal oleh masyarakat desa yang menjadi lokasi implementasi-program, dibandingkan tempat lain yang belum ada implementasinya, dan masyarakat beranggapan bahwa program-program ini sangat bermanfaat. Untuk dapat mewujudkan wilayah yang bebas kebakaran lahan, maka berbagai upaya untuk memastikan keberlanjutan program-program pencegahan kebakaran tersebut menjadi sangat penting. 


\section{Sorotan Utama}

Riset ini mengamati norma-norma dan praktik-praktik pembakaran dan tanpa bakar yang sedang berlangsung pada sejumlah petani yang tinggal di Provinsi Riau. Termasuk dalam temuan utama adalah:

- Berdasarkan riset yang dilakukan menunjukkan bahwa telah terjadi perubahan norma budaya terkait pembakaran di lokasi riset. Di masa lalu, penggunaan api dianggap sebagai hal yang dapat diterima oleh masyarakat dan sesuai dengan praktik budaya mereka dalam pengelolaan lahan. Dengan adanya Instruksi Presiden yang melarang pembakaran, para petani di wilayah tersebut telah bergeser dari praktik pembakaran. Mereka menerima praktik-praktik tanpa bakar dan berharap anggota masyarakat tidak lagi melakukan pembakaran dalam mengelola lahan mereka.

- Menanamkan norma-norma budaya yang baru terkait pesan tentang pembakaran akan menjadi sangat penting untuk melangkah maju dalam upayaupaya pencegahan kebakaran. Semakin meluasnya perilaku tanpa bakar di kalangan para petani perlu digaungkan lebih jauh lagi sehingga transisi menuju norma tanpa bakar terus berlanjut.

- Kurangnya praktik-praktik pengelolaan lahan tanpa bakar yang hemat biaya penghambat transisi para petani untuk menuju norma tanpa bakar. Berlanjutnya keberadaan kabut asap juga teramati oleh para petani dan hal ini dapat mengembalikan perilaku untuk membakar dan mendorong pada kecenderungan untuk membakar yang lebih besar-“jika orang lain masih membakar, mengapa saya tidak?"

- Tergeraknya petani untuk menerapkan praktik-praktik tanpa bakar disebabkan oleh tekanan eksternal - yaitu untuk mematuhi larangan presiden terkait pembakaran dan karena ketakutan menghadapi hukuman (jika tertangkap melakukan pembakaran). Apabila faktor eksternal dihilangkan, maka petani akan kembali melakukan pembakaran, selama tidak ada alternatif tanpa bakar yang bisa mereka terapkan.

- Bantuan secara berlanjut untuk membantu petani meningkatkan kapasitas pengelolaan lahan tanpa bakar secara mandiri adalah penting untuk keberlanjutan perilaku tanpa bakar.

- Dibutuhkan berbagai perubahan yang lebih transformatif terhadap sistem dan pilihan-pilihan penghidupan (mata pencaharian) yang menjadi kebutuhan para petani. Petani membutuhkan dukungan dan pelatihan untuk mengubah lahan mereka menjadi pilihan-pilihan jenis tanaman perenial dan tanaman yang sesuai dengan pembasahan kembali (rewetting) lahan yang hal ini tidak sering membutuhkan pembersihan dan penggunaan api. Opsi-opsi perbaikan penghidupan juga sangat dibutuhkan, yang memungkinkan petani untuk memanfaatkan lahan secara efektif agar diperoleh penghasilan yang baik. 


\subsection{PENDAHULUAN DAN METODOLOGI}

Kebakaran lahan gambut di Indonesia merupakan penyebab utama munculnya kabut asap yang berdampak pada kesehatan manusia dan perekonomian daerah, khususnya selama musim kemarau di Sumatra dan Kalimantan. Kabut asap memicu bencana setempat dengan implikasi ekonomi, sosial dan kesehatan yang signifikan, baik di Indonesia, maupun di wilayah lain sekitarnya. Kebakaran lahan gambut umumnya diawali oleh anggota masyarakat untuk sejumlah alasan, dan kebakaran gambut dapat menjadi sangat sulit untuk dikontrol dan terus menghasilkan kabut asap tebal dalam jumlah yang sangat banyak ketika lahan tersebut terbakar. Secara alami, kebakaran jarang terjadi dan terbatas, namun dengan pembersihan dan drainase lahan secara ekstensif untuk pengembangan pertanian dan hutan tanaman, maka pembakaran lahan gambut menyebar luas, khususnya pada tahun-tahun kering. Pencegahan kebakaran telah diakui sebagai kunci utama untuk memastikan kebakaran tidak terjadi, mengingat ketika sudah telanjur terjadi, kebakaran akan sangat sulit untuk dikendalikan dan memerlukan biaya yang mahal. Berbagai macam program pencegahan telah diujicobakan pada beberapa desa di Riau melalui pendekatan-pendekatan yang berbeda, tetapi belum ada upaya bersama untuk memahami bagaimana program pencegahan kebakaran ini dapat mengubah psikologi dan perilaku masyarakat.

Dua riset telah dilaksanakan di Provinsi Riau pada tahun 2019 untuk memahami perilaku pembakaran atau tanpa bakar masyarakat pada beberapa desa, yang telah maupun belum berpartisipasi pada program-program pencegahan yang diselenggarakan oleh dua industri kehutanan dan perkebunan yang besar. Petani yang tinggal di desa yang telah mengikuti program-program pencegahan kebakaran (yaitu desa program) maupun yang belum mengikuti program serupa (yaitu desa kontrol) direkrut oleh tim peneliti. Survei yang pertama adalah riset pelingkupan (scoping), yang terdiri dari sekitar satu jam wawancara semiterstruktur dengan 49 petani pada delapan desa di Kabupaten Pelalawan, Riau. Fase pertama riset ini bertujuan untuk mengetahui pemahaman masyarakat tentang keputusan-keputusan untuk tindakan pembakaran atau tanpa bakar di masa lalu dan saat ini, oleh masyarakat yang berada di dalam maupun di luar desa. Survei yang kedua berupa 30-45 menit wawancara yang dirancang berdasarkan informasi yang diperoleh dari survei pertama, yang memungkinkan dilakukannya kuantifikasi keputusan bakar dan tanpa bakar, dan mengamati bagaimana sistem nilai dan kepercayaan masyarakat mempengaruhi keputusan tersebut, yang dilakukan pada 16 desa di Kabupaten Pelalawan, Siak, dan Bengkalis, Riau. Survei yang kedua juga bertujuan untuk mengetahui efektivitas elemen-elemen program pencegahan kebakaran dalam mengubah perilaku masyarakat. Total sejumlah 160 wawancara telah dilakukan pada survei yang kedua. 


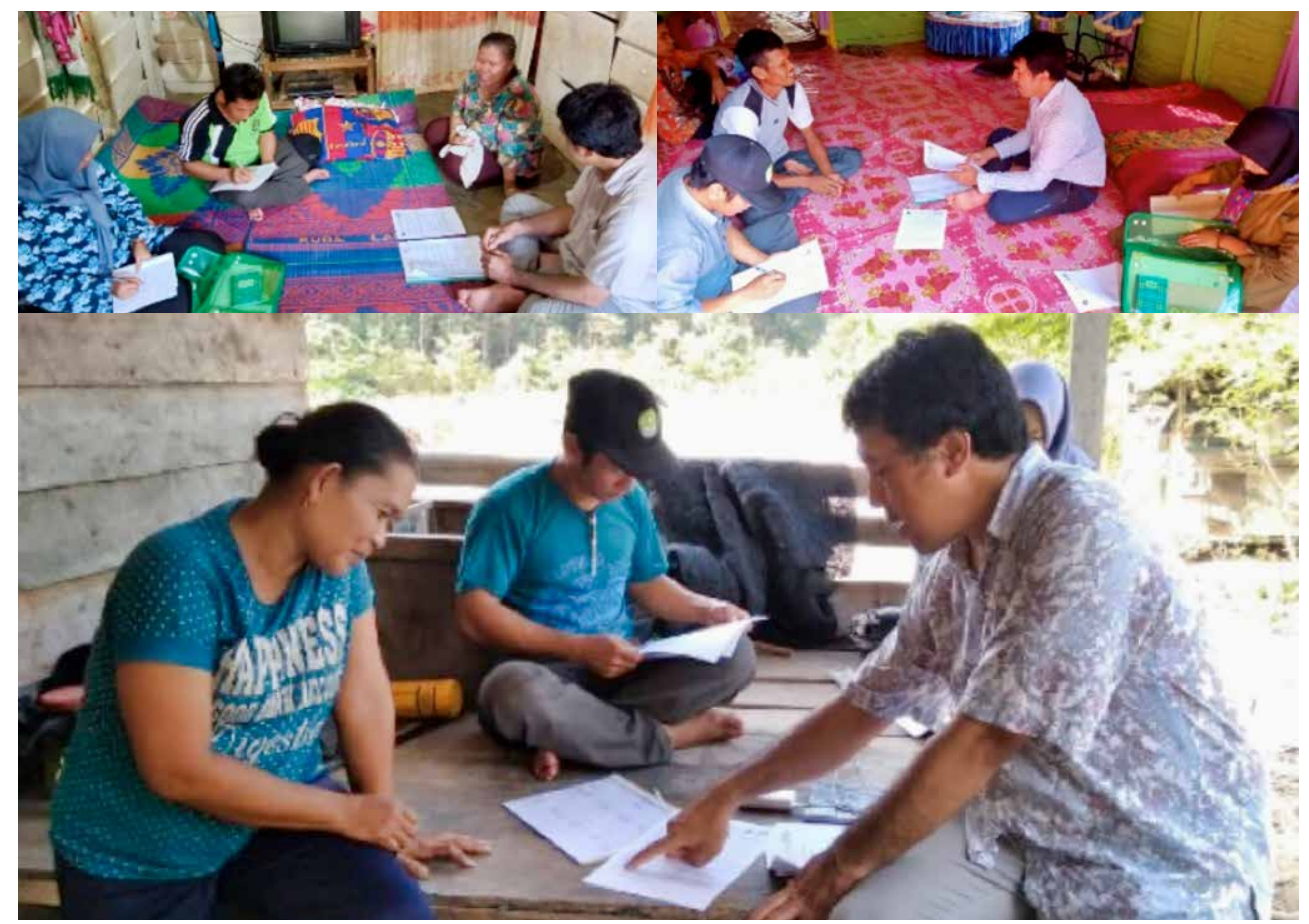

\subsection{HASIL}

Partisipan dari desa-desa program melaporkan bahwa mereka lebih bergantung pada praktik-praktik pembakaran sebelum larangan pembakaran diberlakukan, sementara itu hanya sekitar dua pertiga dari peserta di desa-desa kontrol yang telah menggunakan api sebelumnya. Walaupun terdapat kesamaan alasan penggunaan api, partisipan program lebih cenderung memandang pembakaran sebagai cara untuk membersihkan dan menyuburkan lahan, sekaligus untuk membersihkan gelondongan kayu berukuran besar. Partisipan kontrol cenderung menganggap pembakaran sebagai suatu tradisi dan cara alami untuk mengelola lahan mereka. Kegunaan dan kepercayaan masyarakat akan pembakaran merupakan pemicu utama dilakukannya pembakaran dan hal ini masih terjadi pada kedua kelompok petani, dengan pembakaran yang dilakukan untuk:

- membersihkan lahan;

- menghemat tenaga kerja;

- memudahkan penanaman;

- meminimalkan penyakit; dan

- meningkatkan kesuburan lahan. 
Faktor-faktor seperti umur, etnik, tingkat pendidikan, gender, kepala rumah tangga, atau kebutuhan tenaga kerja tidak berkontribusi pada perilaku membakar mereka di masa lalu. Para pemilik lahan lebih cenderung menggunakan api untuk membersihkan lahan pada masa sebelumnya. Namun demikian, sekarang ini perilaku pembakaran telah berubah. Pada saat survei dilakukan, sangat sedikit petani kontrol maupun program yang mengaku membakar lagi lahan mereka. Motivasi mereka untuk berhenti membakar utamanya adalah karena terdorong ketakutan jika tertangkap dan mendapatkan hukuman dari pihak yang berwenang. Pada tingkat motivasi yang lebih rendah, para petani juga berhenti membakar karena khawatir api akan berpindah lokasi dan berdampak pada lahan milik tetangga mereka; atau khawatir akan asap dan dampak parah yang ditimbulkan oleh kebakaran pada kesehatan mereka dan juga orang lain, juga terhadap lingkungan.

Intervensi tingkat tinggi oleh instansi pemerintahan, termasuk petugas penyuluh dan militer, merupakan hal yang menjadi perhatian, mengingat partisipan dapat mengingat kehadiran mereka di desa untuk mendorong masyarakat menghentikan pembakaran. Selain itu, pada desa kontrol dan program, para partisipan sangat menyadari adanya program sukarelawan pemadam kebakaran milik pemerintah, "Masyarakat Peduli Api", dan beranggapan bahwa program tersebut bermanfaat. Sesuai dugaan, programprogram yang didanai oleh pihak swasta secara signifikan jauh lebih dikenal dan dianggap secara signifikan jauh lebih bermanfaat di desa-desa program dibandingkan dengan di desa-desa kontrol. Penting dicatat bahwa nampaknya para petani tidak bisa secara jelas melihat perbedaan antar program dengan baik. Mereka cenderung menggunakan istilah yang umum seperti 'sosialisasi' atau 'penyuluhan' dalam menyebutkan program-program pencegahan kebakaran baik dari pemerintah maupun industri swasta. Lebih penting lagi, Instruksi Presiden yang melarang penggunaan api, yang dilanjutkan dengan penegakannya melalui personel militer, diterima oleh desa-desa kontrol maupun program, dan diberikan peringkat tinggi untuk manfaatnya dalam pencegahan kebakaran. Secara umum, merupakan hal yang tidak mungkin untuk mengkaitkan perubahan petani menuju perilaku tanpa bakar ke hanya satu program atau salah satu bagian dari program. Merupakan hal penting untuk dicatat bahwa sejauh ini, banyak program pemerintah seperti Masyarakat Peduli Api yang cenderung lebih berfokus pada peningkatan kapasitas petani untuk menangani kebakaran. Larangan pemerintah terkait pembakaran berfokus pada menghentikan secara total penggunaan api. Sangat sedikit program yang dirancang dengan maksud untuk mengubah perilaku intrinsik seputar pembakaran dengan mendukung para petani untuk membuat perubahan menuju praktik-praktik lahan tanpa bakar. Programprogram yang dilaksanakan oleh perusahaan swasta menjadi pengecualian dalam hal ini, mengingat mereka secara khusus diselenggarakan untuk mendukung petani dan meningkatkan kapasitas mereka untuk mengelola lahan tanpa api. Program-program ini juga meningkatkan kesadaran tentang dampak buruk asap dan memberikan peluang bagi para petani untuk mengadopsi praktik-praktik pengelolaan lahan alternatif, 
dengan menyediakan bantuan pertanian bagi mereka. Para petani sering bergantung pada lahan untuk penghidupan mereka dan oleh karena itu, meningkatkan kapasitas mereka untuk hidup dari lahan tanpa pembakaran merupakan langkah penting untuk mengurangi perilaku membakar mereka.

Para petani memperhatikan bahwa penggunaan praktik-praktik alternatif untuk pengelolaan lahan bergantung pada kemampuan finansial mereka. Larangan penggunaan api secara tidak sengaja telah menyebabkan ketimpangan sosial bagi para petani miskin dengan ukuran lahan yang lebih kecil dan kemampuan finansial yang lebih rendah, mengingat sekarang mereka memiliki lebih sedikit pilihan dalam mengelola lahan mereka. Terdapat laporan bahwa sejumlah petani meninggalkan lahan mereka karena tidak mampu mengelola lahan tanpa pembakaran. Para responden melaporkan bahwa para petani yang lebih kaya dapat menggunakan peralatan/mesin untuk membersihkan lahan, membeli bahan kimia untuk mengendalikan gulma, dan menggunakan pupuk untuk memperoleh hasil yang lebih baik dari lahan mereka. Penggunaan api untuk menyiapkan lahan dapat menghemat tenaga kerja dan waktu, selain juga efisien, karena petani dapat memanfaatkan abunya untuk "menyuburkan" lahan mereka. Bagi petani miskin, metode pengelolaan lahan ini penting, dan mungkin merupakan satu-satunya pilihan hemat biaya. Partisipan dalam riset ini secara khusus meminta lebih banyak pelatihan penyuluhan untuk membantu mereka mengelola lahan tanpa pembakaran. Dukungan berupa peralatan mesin, pupuk, bibit dan bahan kimia untuk mengendalikan gulma, baik dari pemerintah maupun industri swasta juga menjadi catatan khusus.

Mengelola lahan tanpa pembakaran telah terbukti merupakan tantangan bagi banyak petani. Seorang petani melaporkan telah mencoba menanam 10 ha padi namun gagal berproduksi. Petani lain menyampaikan bagaimana tanamannya terdampak oleh penyakit. Para partisipan dari riset ini menyampaikan bahwa mereka telah mengubah sistem penanaman mereka menjadi kelapa sawit dan/atau karet sejak larangan penggunaan api diberlakukan. Kami bertanya kepada partisipan tentang praktik-praktik pengelolaan lahan tanpa bakar. Tiga hal yang paling sering digunakan dalam praktikpraktik tanpa bakar di kedua desa adalah:

- Memotong dan menumpuk material tanaman.

- Penggunaan bahan kimia untuk mengendalikan gulma.

- Mengubah sistem penanaman dari tanaman tahunan menjadi tanaman perenial, seperti halnya kelapa sawit dan karet.

Kami juga mendapatkan bahwa para petani akan segera kembali melakukan pembakaran saat ini atau di masa mendatang apabila tidak terdapat larangan penggunaan api. Para petani pada riset ini masih dihadap pada kurangnya pilihanpilihan alternatif pengelolaan lahan yang dapat diandalkan dan hemat biaya. Selain itu, terdapat pemahaman yang kuat bahwa pembakaran tidak hanya merupakan cara yang ekonomis untuk membersihkan lahan, tetapi juga dapat mendorong pertumbuhan dan menjauhkan tanaman dari penyakit. 
Para partisipan menganggap bahwa tanggung jawab mencegah kebakaran ada di tangan mereka sendiri, perusahaan-perusahaan kehutanan setempat dan pemerintah di tingkat pusat, provinsi dan lokal. Sebagian besar partisipan beranggapan bahwa saat ini perusahaan hutan tanaman industri dan kelapa sawit tidak pernah menggunakan api untuk membersihkan lahan. Mereka berpikir bahwa orang-orang di desa lain yang lebih mungkin untuk menggunakan api dibandingkan kedua jenis perusahaan tersebut. Temuan ini penting karena rasa tanggung jawab yang dimiliki masyarakat terhadap program pencegahan kebakaran akan membantu memotivasi masyarakat untuk merasa bertanggung jawab mencegah kebakaran dan meningkatkan perilaku tanpa bakar mereka.

Partisipan di desa kontrol maupun program merasa cukup terbantu dalam melakukan kegiatan tanpa bakar di desa mereka. Mereka merasa mampu untuk mengelola lahan mereka tanpa api. Namun demikian, kebanyakan partisipan menyatakan bahwa mereka membutuhkan bantuan lebih lanjut untuk menerapkan praktik-praktik pengelolaan lahan tanpa bakar. Mereka membutuhkan dukungan pertanian seperti peralatan/mesin, pupuk dan herbisida. Dengan menggunakan Relative Autonomy Index (Ryan dan Deci 2000), riset ini memperoleh bahwa perilaku tanpa bakar petani belum bersifat otonom, yang mengindikasikan bahwa perilaku tanpa bakar perlu dipertahankan melalui tekanan eksternal seperti kebijakan larangan api dan bantuan pertanian, sampai satu waktu ketika perilaku tanpa bakar telah terarusutamakan ke dalam cara berpikir dan praktik-praktik mereka.

\subsection{REKOMENDASI}

Berikut ini adalah beberapa rekomendasi utama dari hasil riset kami:

- Mempertahankan larangan pembakaran sangat penting sampai perilaku tanpa bakar menjadi lebih bersifat otonom dan berkelanjutan.

- Saat ini terdapat permintaan yang tidak terlihat untuk pembakaran yang dapat memunculkan kembalinya pembakaran dalam skala besar apabila larangan tersebut dihapuskan.

- Program-program pemerintah, seperti MPA, telah dikenal secara meluas di kalangan masyarakat dalam survei kami - oleh karena itu pengembangan program-program ini untuk mengakses jaringan kerja di desa merupakan langkah yang tepat untuk menanamkan keberlanjutan praktik-praktik tanpa bakar.

- Meningkatkan kesadaran terkait dampak kesehatan yang disebabkan oleh kabut asap adalah penting, namun itu saja tidak cukup untuk membawa perubahan perilaku. Kabut asap sudah dianggap biasa dan menjadi bagian dari lingkungan yang dihadapi oleh masyarakat. Seringkali dampak buruk kabut asap tidak serta 
merta terlihat oleh masyarakat, sementara hilangnya peluang untuk melakukan penanaman secara signifikan berdampak terhadap penghidupan mereka.

- Saat ini upaya-upaya pemadaman api dengan memberikan penghargaan dan perhatian kepada masyarakat yang terdampak api, yang hal ini dapat menyebabkan konsekuensi yang tidak diinginkan.

- Penghargaan dan perhatian dapat secara tidak sengaja memperkuat dan mendorong perilaku penggunaan api.

- Fokus perlu diletakkan pada peningkatan kapasitas masyarakat untuk mengelola lahan tanpa api.

- Menanamkan norma-norma sosial seputar perilaku tanpa bakar akan menjadi penting di masa mendatang.

- Mengubah pesan untuk merefleksikan fakta bahwa sebagian besar pembakaran telah dihentikan dan masyarakat mengharapkan dan menyetujui praktik-praktik tanpa bakar.

- Bekerja bersama tokoh-tokoh petani dan masyarakat untuk menunjukkan praktik terbaik.

- Keberadaan kabut asap cenderung mengembalikan perilaku membakar dan kemungkinan besar akan mengarah pada kecenderungan untuk membakar "jika orang lain masih membakar, mengapa saya tidak?"

- Mendukung dan melatih petani dalam praktik-praktik pertanian tanpa bakar adalah sangat krusial.

- Termasuk meningkatkan akses pada peralatan/mesin - lebih dari setengah partisipan menginginkan akses pada penggunaan alat berat.

- Mesin-mesin yang berkapasitas dan berukuran kecil kemungkinan akan lebih efektif dibandingkan penggunaan alat berat - yaitu dapat membantu petani agar terampil membersihkan lahan dan meningkatkan kemandirian mereka.

- Pelatihan dan peningkatan kapasitas untuk pertanian tanpa bakar.

- Mendukung perubahan sistem penghidupan (mata pencaharian) - menjadi opsiopsi berbasis perenial yang tidak menuntut pembersihan lahan dan penggunaan api secara berulang.

- Opsi-opsi perbaikan penghidupan juga sangat dibutuhkan, yang memungkinkan petani untuk memanfaatkan lahan secara efektif agar diperoleh penghasilan yang baik.

- Petani yang lebih miskin membutuhkan dukungan tambahan untuk mengelola lahan tanpa bakar, mengingat mereka tidak memiliki akses terhadap sumber daya yang dibutuhkan dengan kemampuan mereka sendiri - termasuk di dalamnya adalah akses terhadap bibit, pupuk, herbisida dan peralatan/mesin. 


\subsection{PUSTAKA}

Rohadi D. 2017. Zero-burning policy hurts small farmers -a flexible approach is needed. The Conversation. [diakses 9 September 2018]. http://theconversation.com/zeroburning-policy-hurts-small-farmers-a-flexible-approach-is-needed-77969

Ryan RM dan Deci EL. 2000. Self-determination theory and the facilitation of intrinsic motivation, social development, and well-being. American psychologist, 55(1): 68. 



\subsection{LATAR BELAKANG}

Perhatian dan desakan akan kelestarian telah dimulai sejak beberapa dekade lalu, bahkan ketika agenda global tentang pembangunan lestari belum dibentuk dan disepakati. Tekanan-tekanan untuk menjawab isu-isu kelestarian didorong oleh penegakan peraturan, persaingan, dan kekhawatiran konsumen (Sarkis 1998, Berns dkk. 2009). Banyak perusahaan merespons dengan memperbaiki model bisnis, memenuhi persyaratan untuk standar kelestarian (misalnya ISO 14000), memperbaiki rantai pasok, mengelola kualitas lingkungan hidup, dan melaksanakan analisis daur hidup (Sarkis 1998; Wu dan Pagell 2011). Komitmen perusahaan menunjukkan pentingnya kelestarian untuk mempertahankan dan mengembangkan bisnis (Cantele dan Zardini 2018). Banyak perusahaan mengadopsi praktik-praktik kelestarian untuk mendapatkan keunggulan kompetitif, misalnya nilai dari merek (Resta dkk. 2017). Namun, perusahaan membutuhkan biaya dan investasi untuk mewujudkan praktik-praktik kelestarian.

Dalam beberapa dekade terakhir, banyak bisnis skala besar telah mengadopsi berbagai praktik kelestarian dengan fokus pada efisiensi energi dan material serta penggunaan energi terbarukan (Ritala dkk. 2018). Namun demikian, diperlukan inovasiinovasi yang radikal dan sistemik untuk mendukung transformasi yang meluas. Model bisnis adalah salah satu alat yang dapat digunakan untuk mengidentifikasi inovasiinovasi tersebut (Boons dkk. 2013). Model bisnis yang mengedepankan aspek sosial dan lingkungan akan mengarah pada peningkatan nilai dan penjualan pada perusahaan (Esslinger 2011). Aspek-aspek ini merupakan landasan yang penting untuk model bisnis berkelanjutan, yang dibangun atas dasar konsep triple bottom line ${ }^{2}$ dari keuntungan ekonomi, sosial dan lingkungan hidup (Evans dkk. 2017). Aspek-aspek tersebut ditangkap melalui pengembangan model bisnis yang disebut Triple-Layered Business Model Canvas (TLBMC) atau kanvas model bisnis tiga lapisan (Joyce dan Paquin 2016), yang merupakan pengembangan dari Business Model Canvas (BMC) atau kanvas model bisnis (Osterwalder dan Pigneur 2010). Jika BMC dibangun untuk membantu proses penciptaan, penangkapan, dan pengantaran nilai, dengan fokus pada aspek ekonomi, maka TLBMC terdiri atas kanvas model bisnis ekonomi, daur hidup lingkungan, dan pemangku kepentingan sosial. Pada riset aksi partisipatif, kami menguji coba kanvas model bisnis yang dikembangkan oleh Osterwalder dan Pigneur (2010) atau lapisan pertama dari TLBMC. Tujuan dari uji coba BMC ini adalah untuk mengenalkan alat formulasi bisnis pada masyarakat lokal. Dalam bab ini, kami akan menjelaskan dan membagikan pengalaman pengembangan model bisnis tingkat lokal dan merekomendasikan sebuah alternatif model bisnis yang diperbarui.

2 Konsep 'triple bottom line' dicetuskan oleh Elkington (1994) dan merupakan strategi 'win-win-win' yang secara simultan memformulasikan keuntungan bagi perusahaan, pelanggan dan lingkungan. 
Untuk melaksanakan komitmen Pemerintah Indonesia dalam pengurangan emisi gas rumah kaca, banyak upaya strategis telah dilakukan. Salah satu di antaranya adalah mencegah berulangnya kebakaran hutan dan lahan melalui restorasi lahan gambut yang rusak. Proyek restorasi dipengaruhi oleh konteks sosial, mulai dari penentuan cakupan proyek, tujuan, sampai pelaksanaan restorasi - termasuk revitalisasi atau menemukan alternatif mata pencaharian masyarakat (Puspitaloka 2018). Sebuah model bisnis partisipatif berkelanjutan menjadi alat penting bagi fasilitator dan masyarakat lokal untuk mengidentifikasi dan merumuskan alternatif mata pencaharian secara sistematis. Model bisnis harus mampu mengembangkan partisipasi masyarakat dan meminimalisir dampak lingkungan dengan memperhatikan konteks sosial ekologi. Tujuan-tujuan tersebut penting karena berbagai tekanan antropogenik, dalam bentuk aktivitas-aktivitas manusia, telah mengubah kondisi lanskap (Meijaard dkk. 2013). Pada lahan gambut, bisnis-bisnis menguntungkan, baik legal maupun ilegal, misalnya penambangan (Dommain dkk. 2016), pembalakan (Dommain dkk. 2016; Hergoualc'h dkk. 2017), dan masih banyak lagi telah menyebabkan gangguan pada fungsi hidrologis gambut. Mengingat kondisi tersebut, maka alternatif mata pencaharian yang menarik dan menguntungkan bagi masyarakat lokal, yang juga dapat meminimalisir eksternalitas negatif pada lingkungan dan menuju kelestarian, menjadi hal yang krusial. Kami berharap dapat menyediakan model bisnis berkelanjutan bagi masyarakat yang dapat diterapkan untuk, dan berkontribusi pada agenda pencegahan kebakaran dan restorasi gambut.

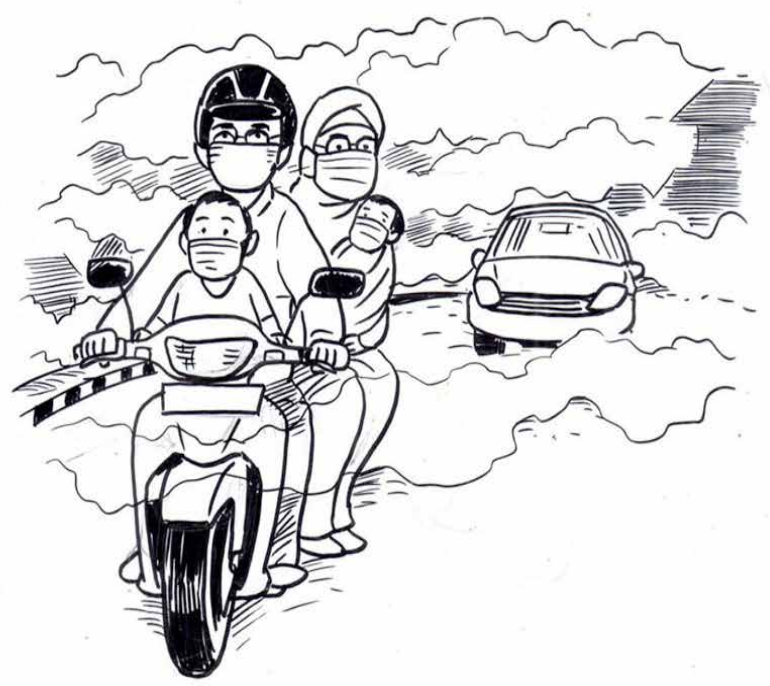

\section{Gambar 3.1 Alternatif mata pencaharian yang berkelanjutan di lahan gambut penting untuk mencegah kerusakan, kebakaran dan kabut asap.}




\subsection{PENGENALAN MODEL BISNIS}

\subsubsection{Definisi model bisnis}

Terdapat beberapa definisi model bisnis menurut sejumlah ilmuwan. Sebagai contoh, Teece (2010) mendefinisikan model bisnis sebagai "desain atau arsitektur dari mekanisme penciptaan, penyampaian dan penangkapan nilai...mendefinisikan cara dari perusahaan menyampaikan nilai kepada pelanggan, menarik pelanggan untuk membayar nilai tersebut, dan mengubah pembayaran tersebut menjadi keuntungan". Geissdoerfer dkk. (2018) menyatakan bahwa "model bisnis adalah representasi dari beragam elemen proposisi nilai, penciptaan dan penyampaian nilai, dan penangkapan nilai yang disederhanakan dan interaksi antara beragam elemen dalam organisasi". Sebuah definisi yang lebih sederhana ditawarkan oleh Osterwalder dan Pigneur (2010) yang menyatakan bahwa "sebuah model bisnis mendeskripsikan berbagai alasan bagi organisasi dalam menciptakan, menyampaikan, dan menangkap nilai”. Berbagai definisi ini memiliki kesepakatan yang sama dalam melihat model bisnis, yaitu bahwa model bisnis harus mengandung proposisi, penciptaan, penyampaian dan penangkapan nilai.

\section{Pertanyaan Kunci}

Apakah proposisi nilai yang diperlukan oleh konsumen?

Bagaimana nilai-nilai ini diciptakan secara efisien dan efektif untuk mendapatkan keuntungan?

Bagaimana model bisnis dapat mendukung upaya-upaya untuk mencapai kelestarian?

\subsubsection{Menuju bisnis model berkelanjutan dan sirkular}

Pada bagian ini akan dijelaskan perbedaan antara model bisnis konvensional atau tradisional dengan model bisnis berkelanjutan dan sirkular. Model bisnis konvensional hanya menjawab pertanyaan-pertanyaan pada aspek ekonomi bisnis, misalnya siapakah pelanggan yang dituju, apa nilai yang diinginkan oleh pelanggan, bagaimana memberi nilai-nilai lebih pada pelanggan, apa saja faktor-faktor internal dan eksternal yang mempengaruhi bisnis dan pertanyaan-pertanyaan lainnya yang relevan (Osterwalder dan Pigneur 2010, Magretta 2002, Teece 2010). Model bisnis berkelanjutan 
dikembangkan dari model bisnis konvensional dengan menambahkan tiga karakteristik dan tujuan baru: 1) penggabungan konsep, prinsip dan tujuan kelestarian dalam model bisnis; 2) pengelolaan para pemangku kepentingan proaktif melalui penciptaan nilai bagi para pihak dalam spektrum yang luas; dan 3) penerapan perspektif jangka panjang. Model bisnis berkelanjutan masih dapat ditingkatkan menjadi sebuah solusi untuk model bisnis sirkular (Geissdoerfer dkk. 2018). Menurut Nikolova dan Mesiano (2018), ekonomi sirkular "secara bertahap memisahkan ekonomi dari konsumsi sumber daya yang terbatas dan berdasarkan atas tiga prinsip: merancang peminimalan limbah dan polusi, menjaga produk-produk dan bahan-bahan pada nilai tertingginya dan pada penggunaannya, dan meregenerasi sistem-sistem alami". Model bisnis sirkular menggabungkan prinsip-prinsip model bisnis berkelanjutan dengan beragam upaya tambahan, yaitu mengintensifkan, mengurangi, menutup, memperlambat, dan mempersempit aliran sumber daya dan dan energi, untuk mengurangi limbah dan kebocoran emisi (Geissdoerfer dkk. 2018).

\subsubsection{Alat-alat untuk merumuskan model bisnis}

\section{Kanvas model bisnis atau Business Model Canvas (BMC)}

Terdapat banyak alat yang dapat digunakan untuk merumuskan model bisnis. Alat yang paling banyak digunakan adalah yang dikembangkan oleh Osterwalder dan Pigneur (2010). BMC adalah sebuah kerangka yang terdiri dari sembilan komponen: segmen pelanggan, proposisi nilai, saluran, hubungan pelanggan, aliran pendapatan, sumber daya kunci, aktivitas kunci, mitra kunci, dan struktur biaya (Gambar 3.2). Segmen pelanggan (1) adalah kelompok atau individual sasaran yang akan dituju dan dilayani. Barang dan jasa yang dikembangkan oleh produsen harus memiliki proposisi nilai (2) tertentu yang sesuai dengan segmen pelanggan yang dituju. Proses untuk menyampaikan nilai ini membutuhkan saluran (3) yang merupakan beragam cara dan upaya untuk memungkinkan sebuah bisnis menjangkau pelanggan dalam menyampaikan proposisi nilai. Ragam tipe hubungan antara bisnis dan setiap segmen pelanggan direpresentasikan oleh hubungan pelanggan (4). Arus pendapatan (5) mendeskripsikan sumber-sumber uang yang mungkin akan dihasilkan oleh perusahaan dari pelanggan. Sejenak melangkah mundur pada proses untuk menghasilkan nilai yang diajukan, sebuah bisnis memerlukan sumber daya kunci (6) yang merepresentasikan daftar dari berbagai macam aset yang diperlukan. Sumber daya kunci ini kemudian diproses melalui aktivitas kunci (7). Untuk menjalankan aktivitas kunci ini, sebuah bisnis harus bekerja dengan jaringan mitra yang direfleksikan melalui mitra kunci (8). Akhirnya, semua biaya yang dikeluarkan didokumentasikan melalui struktur biaya (9). 


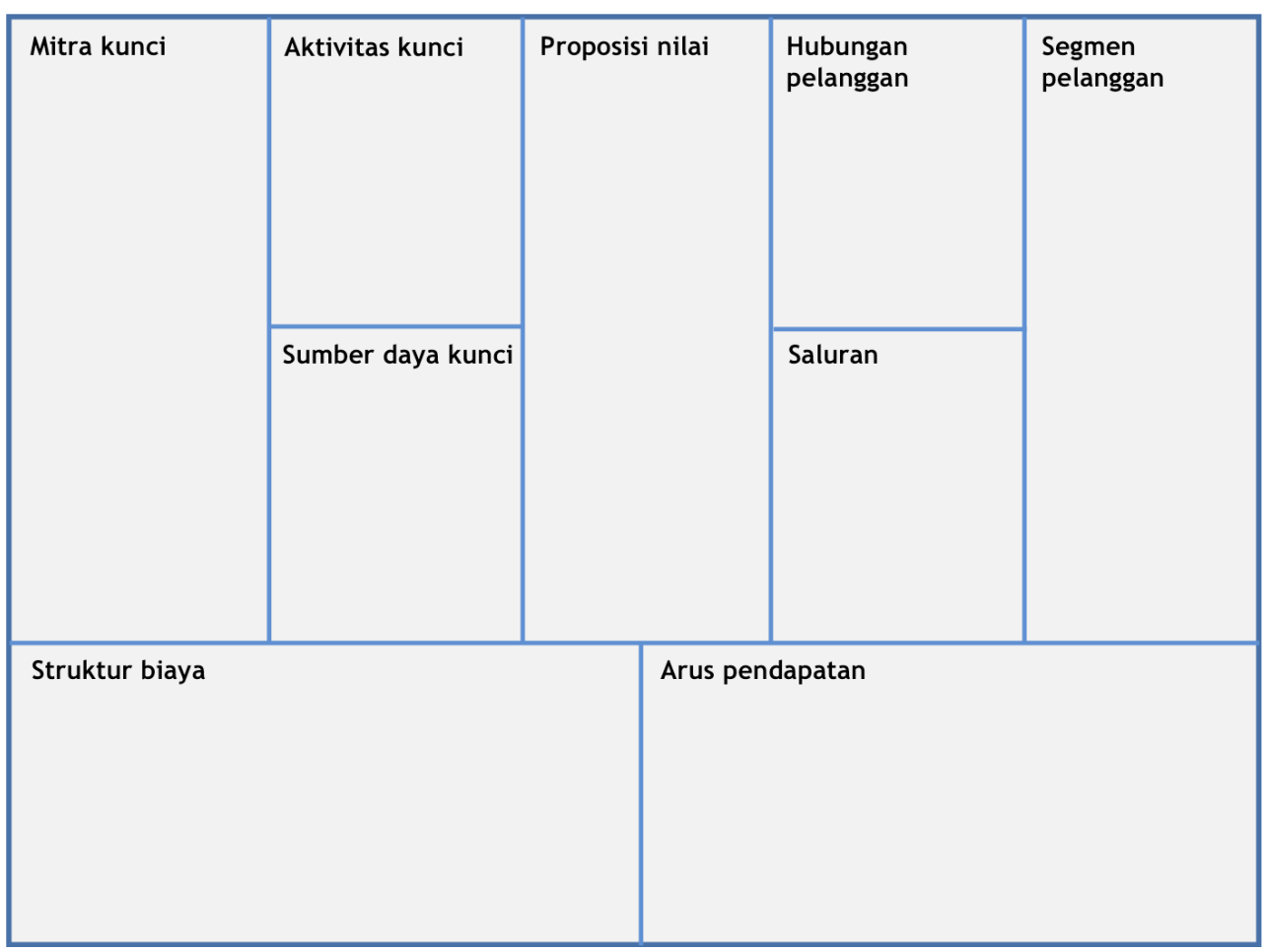

Gambar 3.2 Model bisnis kanvas oleh Osterwalder dan Pigneur (2010).

\section{Kanvas model bisnis tiga lapisan atau Triple Layered Business Model Canvas (TLBMC)}

Salah satu alat yang sesuai untuk model bisnis berkelanjutan dan yang menitikberatkan triple bottom line dari prinsip-prinsip kelestarian adalah TLBMC yang dikembangkan oleh Joyce dan Paquin (2016). TLBMC adalah pengembangan dari model Osterwalder dan Pigneur (2010) yang terdiri atas tiga lapisan (Gambar 3.3). Lapisan pertama adalah model bisnis kanvas ekonomi yang serupa dengan BMC yang dicetuskan oleh Osterwalder dan Pigneur (2010). Lapisan kedua adalah aspek lingkungan hidup yang dibangun dari siklus daur hidup dari dampak lingkungan hidup. Lapisan ketiga adalah aspek sosial yang mengeksplorasi dampak sosial dari bisnis. TLBMC memungkinkan terjadinya koherensi horizontal dan vertikal. Koherensi horizontal didefinisikan sebagai peran model bisnis dalam memfasilitasi "sistem pemikiran yang lebih luas" dan "pandangan yang lebih holistik/menyeluruh" dalam suatu model bisnis. Koherensi vertikal menyelaraskan nilai-nilai yang berbeda dalam aksinya dan saling berhubungan. 
(a)

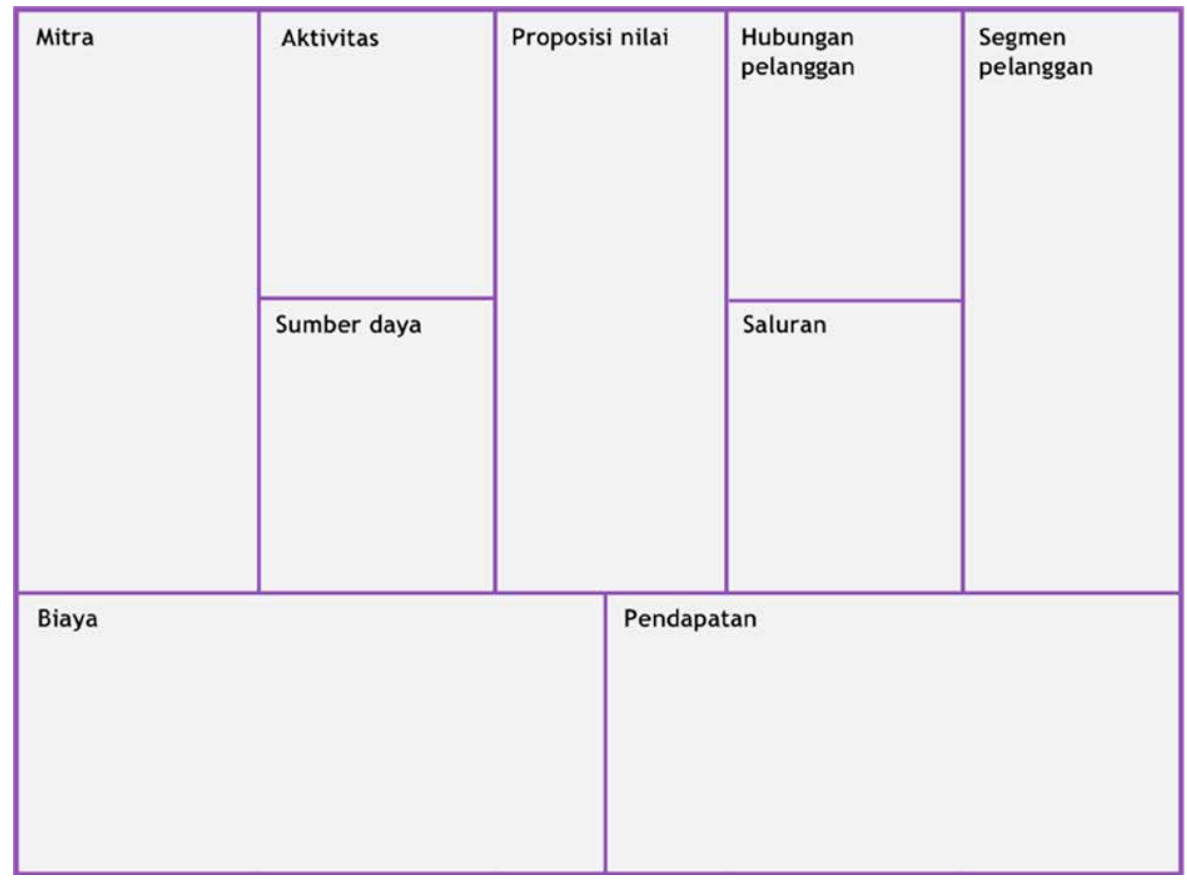

(b)

\begin{tabular}{|c|c|c|c|c|}
\hline \multirow[t]{2}{*}{$\begin{array}{l}\text { Suplai dan } \\
\text { out-sourcing }\end{array}$} & Produksi & \multirow[t]{2}{*}{ Nilai fungsional } & End-of-life & Fase penggunaan \\
\hline & Material & & Distribusi & \\
\hline \multicolumn{2}{|c|}{ Dampak lingkungan } & \multicolumn{2}{|c|}{ Manfaat lingkungan } & \\
\hline
\end{tabular}


(c)

\begin{tabular}{|c|c|c|c|c|}
\hline \multirow[t]{2}{*}{ Masyarakat lokal } & Tata kelola & \multirow[t]{2}{*}{ Nilai sosial } & $\begin{array}{l}\text { Budaya } \\
\text { masyarakat }\end{array}$ & Pengguna akhir \\
\hline & Para karyawan & & $\begin{array}{l}\text { Skala } \\
\text { penjangkauan }\end{array}$ & \\
\hline \multicolumn{3}{|l|}{ Dampak sosial } & \multicolumn{2}{|c|}{ Manfaat sosial } \\
\hline
\end{tabular}

Gambar 3.3 Kanvas model bisnis tiga lapisan (Joyce dan Paquin 2016): (a) kanvas model bisnis ekonomi, (b) kanvas model bisnis siklus hidup lingkungan, dan (c) kanvas model bisnis pemangku kepentingan sosial.

\section{Alat perencanaan model bisnis sirkular atau Circular Business Model Planning Tool (CBMPT)}

Nußholz (2018) mempresentasikan CBMPT dengan mengadopsi model Osterwalder dan Pigneur (2010), yang membantu merumuskan sebuah model yang "mempertahankan dan menggunakan nilai-nilai yang ada pada produk-produk selama mungkin". Alat ini mengintegrasikan prinsip-prinsip sirkular sepanjang siklus hidup dari sebuah produk. Siklus hidup ini adalah sebuah dasar yang membangun CBMPT. Alat ini terdiri atas lima tahap (Gambar 3.4), yaitu: 1) pengumpulan dan pengintegrasian kembali bahan untuk pembuatan produk (pengurangan bahan primer), 2) penjualan pertama untuk memperpanjang masa hidup produk, 3) pengumpulan kedua dan mengintegrasikan kembali (mengatur pengembalian), 4) penjualan tambahan dari produk atau komponennya, dan 5) pemulihan material. 

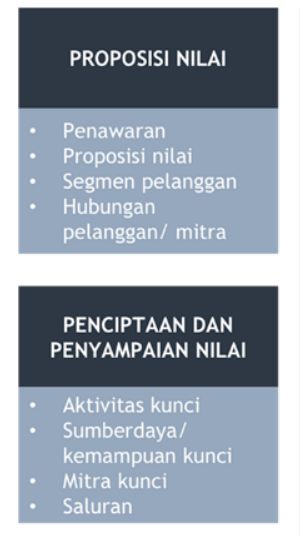

PENANGKAPAN NILAI

Biaya

Aliran pendapatan
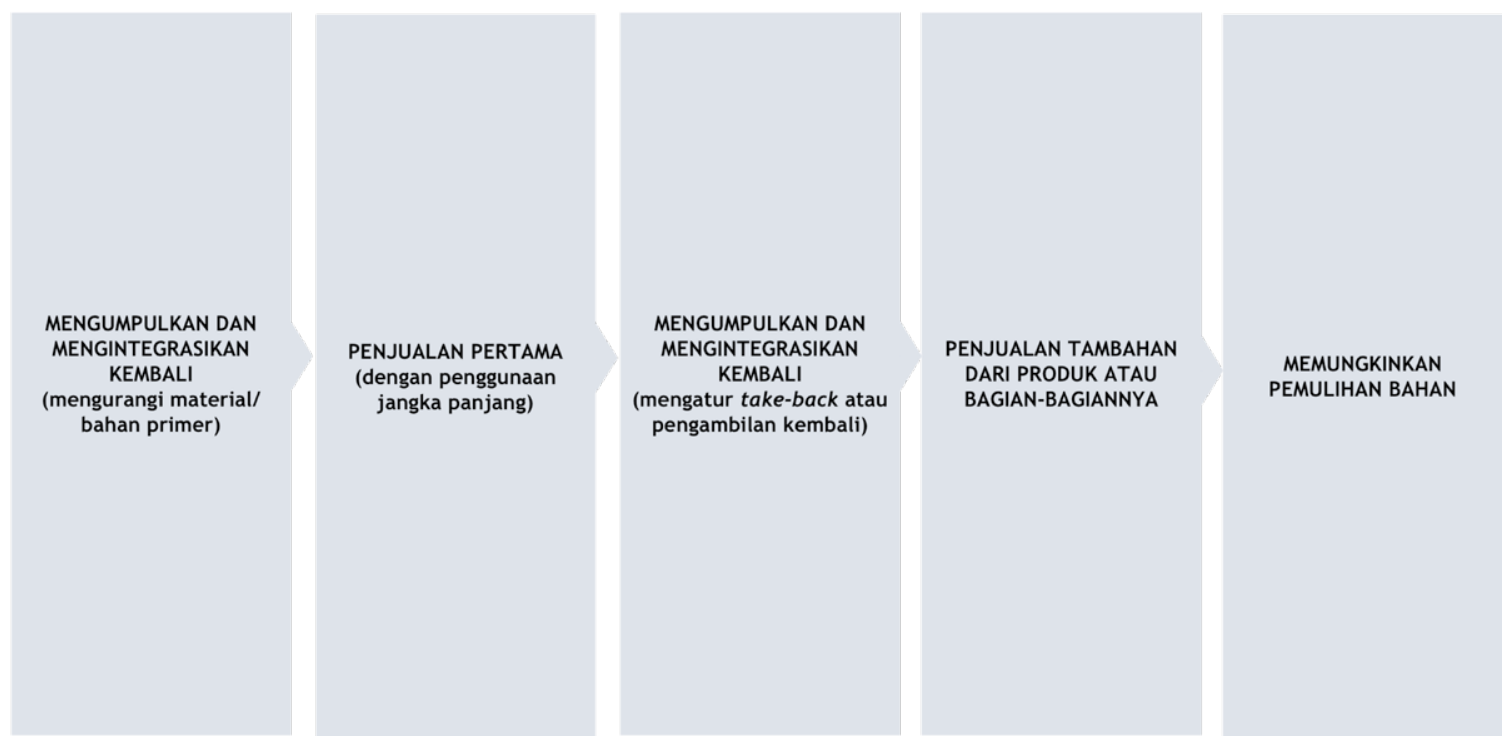

Gambar 3.4 Alat perencanaan model bisnis sirkular (Nußholz 2018). 


\title{
Pertanyaan Kunci
}

\begin{abstract}
Apakah alat yang sesuai untuk menarasikan dan menggambarkan seluruh proses proposisi nilai sampai penangkapan nilai, terutama untuk masyarakat-masyarakat desa?
\end{abstract}

\subsubsection{Kriteria model bisnis yang baik}

Model bisnis konvensional atau tradisional ditandai dengan kemampuan model yang diwujudkan dalam menjawab beragam pertanyaan kunci mengenai pelanggan sasaran, nilai yang diperlukan atau diinginkan oleh pelanggan, dan cara penyampaian nilai kepada pelanggan dengan biaya yang layak dan ekonomis (Osterwalder dan Pigneur 2010, Teece 2010, 2018). Sebuah model bisnis yang baik menyediakan nilai-nilai tambahan bagi pelanggan (Magretta 2002), serta bersifat unik dan sulit ditiru (Teece 2010, 2018). Model bisnis yang baik juga memahami dan mengkaji faktor-faktor internal dan eksternal, misalnya pelanggan, suplai dan lingkungan bisnis (Teece 2010). Selain itu, sebuah model bisnis yang baik dapat mendeteksi atau memahami model bisnis yang ada saat ini disertai dengan analisis strategis (Teece 2018). Namun demikian, kriteria-kriteria tersebut tidak serta merta dapat menjawab isu-isu kelestarian. Bocken dkk. (2014) menyampaikan bahwa model bisnis berkelanjutan dibangun atas dasar kriteria-kriteria berikut: memaksimalkan efisiensi bahan dan energi, memanfaatkan limbah menjadi barang yang bermanfaat, menggunakan bahan terbarukan dan diproses secara alami, mengedepankan fungsi, mengembangkan sebuah solusi untuk scaling-up, dan mengarahkan fokus bisnis untuk memberikan manfaat bagi masyarakat dan lingkungan hidup.

\subsection{STUDI KASUS: PENGEMBANGAN SEBUAH MODEL BISNIS BERSAMA DENGAN MASYARAKAT LOKAL DI DESA DOMPAS, KABUPATEN BENGKALIS, PROVINSI RIAU}

CIFOR bekerja bersama dengan Pusat Studi Bencana Universitas Riau (PSB UNRI) dalam Riset Aksi Partisipatif (RAP). RAP terdiri dari empat fase, yakni refleksi, perencanaan, aksi atau implementasi, dan pemantauan. Pada fase refleksi, kelompok masyarakat melakukan refleksi atas kondisi sosial-ekologi serta pembelajaran dan praktik terbaik. Di fase perencanaan, CIFOR dan PSB UNRI memfasilitasi kelompok masyarakat lokal untuk mengembangkan model bisnis. Pada fase ini, kelompok masyarakat selanjutnya merumuskan rencana aksi yang dapat diterapkan. Kelompok berbasis masyarakat ini terdiri atas Masyarakat Peduli Api (MPA) yang mengelola lahan publik (selanjutnya 
disebut sebagai Arena Aksi 1), kelompok wanita Program Kesejahteraan Keluarga (PKK) dan kelompok tani pria yang mengelola lahan yang dikelola bersama/co-management (Arena Aksi 2 dan 3), kelompok keluarga petani yang mengelola lahan pribadi (Arena Aksi 4, 5, dan 6) dan masyarakat atau rumah tangga Desa Dompas yang mengelola lahan pribadi (Arena Aksi 7). Lahan-lahan ini terletak di dalam wilayah Desa Dompas dan merupakan lahan-lahan dengan tanah gambut.

Secara umum, kami memfasilitasi dan memandu kelompok-kelompok berbasis komunitas ini melalui beberapa langkah: 1) pemilihan barang atau jasa, 2) perumusan model bisnis, 3) perencanaan aksi, 4) aksi/implementasi, 5) pemantauan dan evaluasi, dan terakhir 6) diseminasi dari pembelajaran-pembelajaran. Pada bagian ini, kami akan membahas langkah pertama dan kedua.

\subsubsection{Langkah-langkah dalam memfasilitasi model bisnis bersama dengan kelompok berbasis masyarakat}

\section{Langkah 1 - Memilih barang atau jasa}

Setiap kelompok masyarakat mempunyai ketertarikan masing-masing dalam mengembangkan mata pencaharian. Kami memfasilitasi pemilihan komoditas untuk dikembangkan oleh masyarakat dengan menggunakan studi oleh Ilham dkk. (2019) mengenai rantai nilai komoditas yang potensial untuk lahan gambut. Studi ini juga memuat pentingnya pertimbangan skala ekonomi usaha dalam pemilihan komoditas yang potensial. Kami juga mengelaborasikan hasil dari survei pasar yang ada di sekitar Kabupaten Bengkalis, pemetaan topografi dan survei kedalaman gambut. Kami menyarankan setiap kelompok masyarakat untuk mengidentifikasi dan memilih komoditas atau jasa yang mereka minati. Komoditas atau jasa yang terpilih kemudian dikembangkan oleh masyarakat pada arena aksinya. Setiap kelompok menyadari pentingnya pemahaman dan pertimbangan aspek ekonomi, sosial, teknik dan lingkungan. Diskusi dan pengambilan keputusan terkait pemilihan barang atau jasa juga mencakup pertanyaan-pertanyaan stimulasi yang berhubungan dengan proposisi nilai, namun eksplorasi secara mendalam dilakukan pada langkah kedua.

Secara umum, kelompok berbasis masyarakat di Desa Dompas sepakat untuk menanam kombinasi komoditas kayu dan nonkayu atau jasa pada lahan gambut. MPA (Arena Aksi 1) memilih mengembangkan pohon multifungsi dan ekowisata pemancingan. Kelompok wanita (Arena Aksi 2) dan kelompok tani (Arena Aksi 3) memilih antara kayu multifungsi dan nanas. Kelompok-kelompok keluarga petani (Arena Aksi 4, 5, dan 6) memilih untuk memperkaya kebun karet monokulturnya dengan kopi liberika. Pemerintah Desa Dompas, yang merepresentasikan warga atau rumah tangga, terlibat secara aktif dan menyarankan kelapa hibrida untuk penanaman di lahan pekarangan, mengingat seringnya permintaan komoditas ini oleh rumah tangga (Arena Aksi 7). 


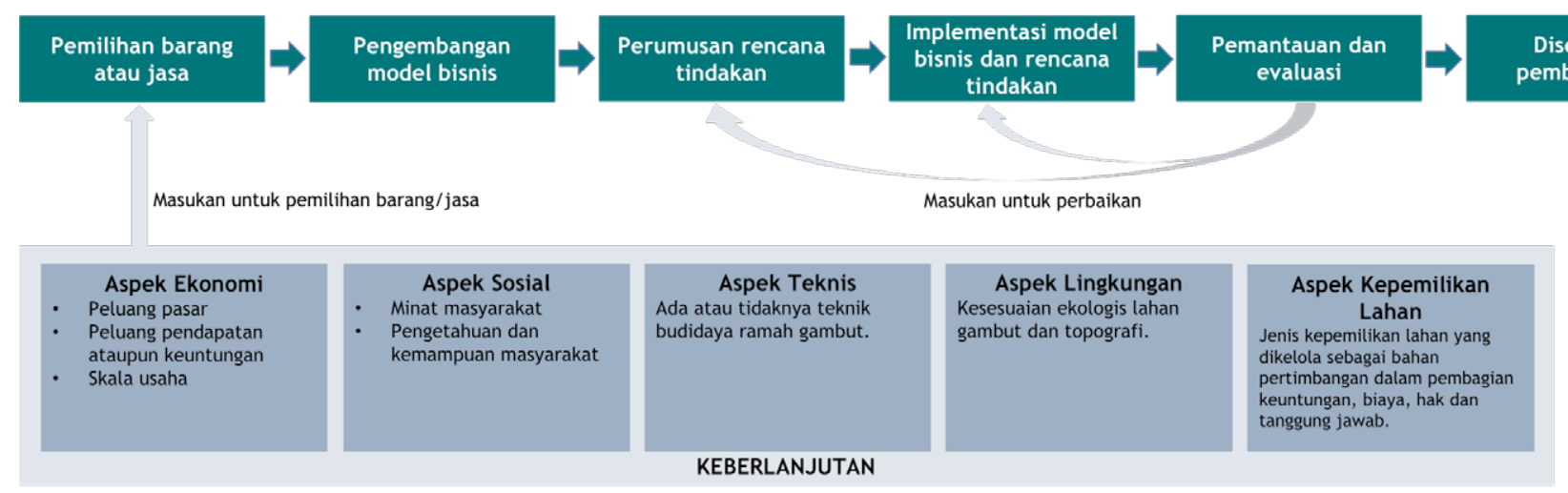

Gambar 3.5 Proses fasilitasi kelompok berbasis masyarakat dalam mengembangkan model bisnis di tingkat tapak. 


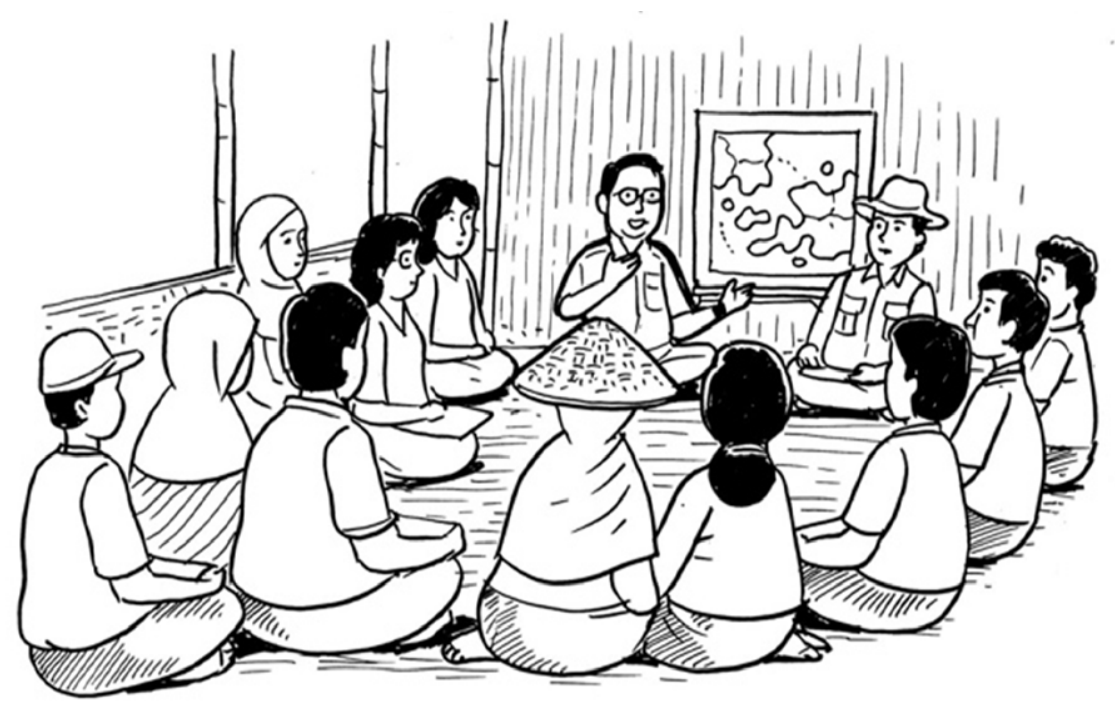

\section{Gambar 3.6 Fasilitator berperan penting dalam memberikan pertanyaan stimulan dan panduan dalam diskusi agar peserta dapat berperan aktif.}

Dalam pengembangan komoditas terpilih ini, kami juga memfasilitasi diskusi pembagian tanggung jawab dan hak, serta keuntungan dan biaya. Hal ini dilakukan dengan pertimbangan aspek kepemilikan lahan yang dikelola oleh perorangan atau kelompok masyarakat. Sebagai contoh, pada Arena Aksi 2 dan 3 yang berada pada lahan milik individu penduduk desa yang dikelola bersama-sama oleh kelompok (co-management), dilakukan perencanaan dan pembuatan kesepakatan bersama. Kesepakatan ini mencakup pembagian hak, kewajiban, biaya dan keuntungan untuk para aktor terkait, misalnya pembagian keuntungan untuk kelompok pengelola, pemilik lahan, dan MPA yang membantu patroli pencegahan kebakaran.

\section{Langkah 2 - Mengembangkan model bisnis}

Setelah tercapai kesepakatan terkait pilihan barang dan jasa, para fasilitator mulai menjelaskan tentang konsep model bisnis. Bersama dengan kelompok-kelompok masyarakat di Desa Dompas, kami mengujicobakan BMC (Osterwalder dan Pigneur 2010). Setiap kelompok masyarakat mengidentifikasi dan mengisi masing-masing komponen BMC dengan panduan dari fasilitator. Ide-ide mereka ditata pada sembilan komponen BMC untuk memudahkan mereka dalam memahami gambaran besar model tersebut dan merumuskan rencana aksi. 


\subsubsection{Contoh kanvas model bisnis dari Desa Dompas, Kabupaten Bengkalis, Provinsi Riau}

Masing-masing kelompok masyarakat di Desa Dompas merumuskan model bisnis yang berbeda untuk arena aksi yang dikelolanya. Pada bagian ini, terdapat tiga model bisnis terpilih yang dirumuskan oleh kelompok masyarakat sebagai pembelajaran. Sebagai catatan, perlu dipahami bahwa model bisnis ini masih jauh dari kesempurnaan, khususnya dalam hal konsistensi antar komponen. Misalnya, pada model bisnis wanatani nanas terdapat berbagai macam proposisi nilai yang penting seperti buah nanas segar, dodol, selai dan lain-lain. Meskipun komponen satu dan lainnya dalam kanvas model bisnis ini saling terkait dan berkesinambungan, pada bagian arus pendapatan, kelompok masyarakat hanya mendata pendapatan dari buah nanas segar saja sebagai pendapatan yang paling utama. Paling tidak beberapa contoh di bawah ini dapat memberikan gambaran dan motivasi bahwa masyarakat di pedesaan bisa mengembangkan model bisnis yang baik dengan adanya pendampingan dari fasilitator.

\section{Kanvas model bisnis ekowisata pemancingan}

MPA Desa Dompas merumuskan model bisnis ekowisata pemancingan seluas 2,2 ha untuk Arena Aksi 1 (Gambar 3.7). Mereka berencana untuk menjangkau dan melayani masyarakat lokal, penggemar aktivitas memancing, agen ikan, dan konsumen akhir dengan mengusulkan bisnis ekowisata pemancingan (segmen pelanggan). Selain menyediakan jasa rekreasi pemancingan dan menyewakan alat-alat pancing, ekowisata pemancingan di Desa Dompas berada di tempat yang menyuguhkan keindahan alam, dan pengalaman kuliner masakan berbahan ikan dan kopi kepada konsumen yang menjadi target (proposisi nilai). Selain membangun hubungan dengan penjual maupun pemasok (saluran), untuk menyampaikan proposisi nilai ini, MPA akan menggunakan platform dalam jaringan (online). Hubungan dengan pelanggan dapat dikelola dengan memperluas jaringan pada komunitas memancing dan juga menyelenggarakan perlombaan memancing (hubungan pelanggan).

MPA Desa Dompas kemudian memproyeksikan bahwa pendapatan dari penerapan model bisnis ini akan diperoleh melalui tiket masuk ke kawasan ekowisata, biaya keanggotaan tahunan untuk penghobi memancing, restoran, penyewaan peralatan, dan penjualan mainan anak (arus pendapatan). Untuk merealisasikan proyeksi pendapatan ini, MPA memerlukan modal finansial dan manusia, mesin kopi, bibit ikan, kolam ikan, dan sarana lainnya (sumber daya kunci). Berbagai sumber daya ini kemudian akan digunakan untuk mendukung dan melaksanakan aktivitas-aktivitas dalam konstruksi dan pemeliharaan (aktivitas kunci). Biaya-biaya yang harus dikeluarkan untuk mengimplementasikan model bisnis ini termasuk biaya konstruksi, upah dan gaji pekerja, dan bibit ikan (struktur biaya). Dengan memperhatikan keterbatasan jaringan dan kepemilikan modal, MPA merencanakan untuk membangun kemitraan dan jaringan dengan perusahaan swasta melalui program tanggung jawab sosial perusahaan atau 


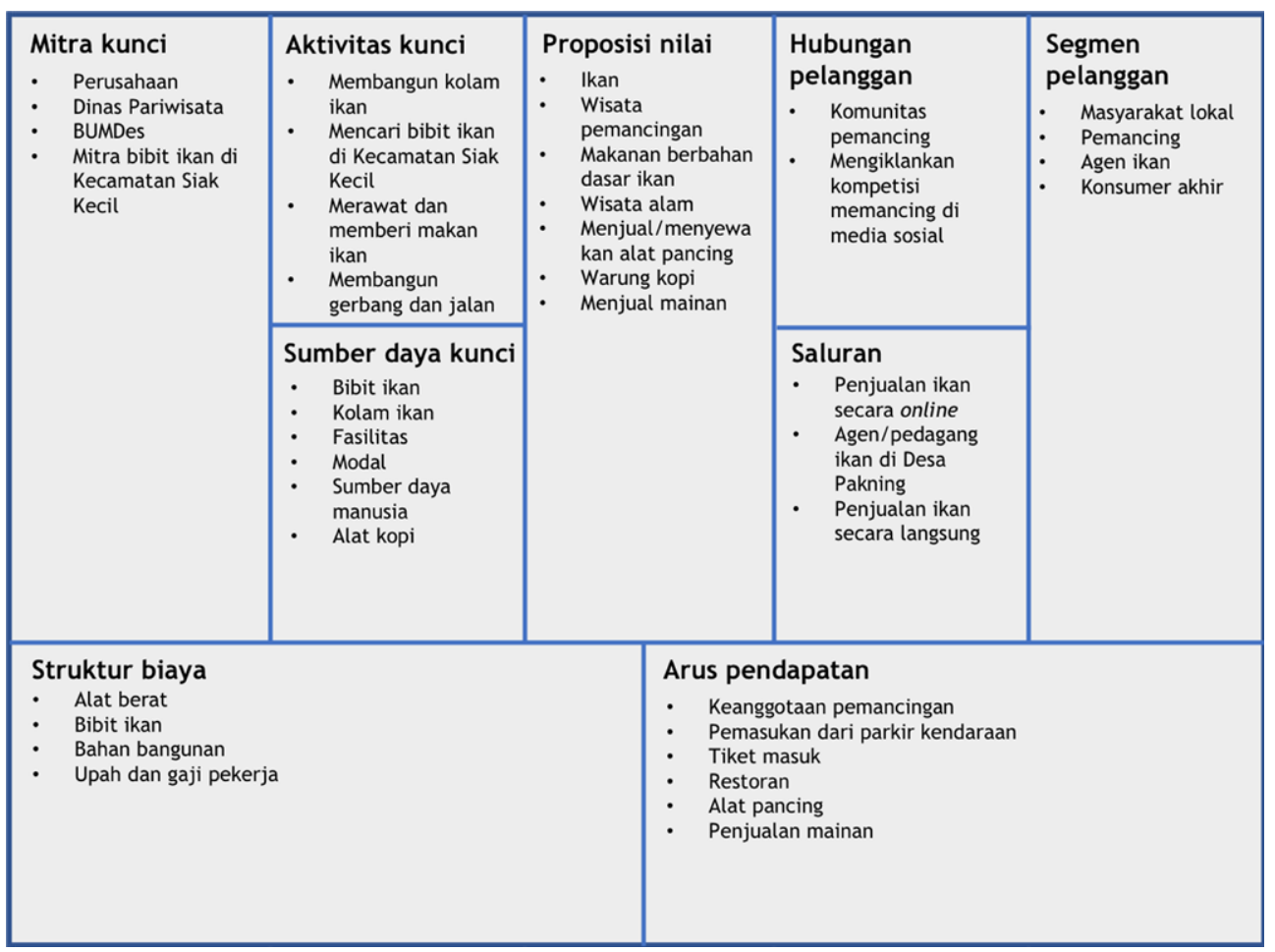

Gambar 3.7 Kanvas model bisnis untuk ekowisata pemancingan yang dirumuskan oleh pengelola Arena Aksi 1 (MPA).

Corporate Social Responsibility (CSR), Dinas Pariwisata Kabupaten Siak, Badan Usaha Milik Desa (BUMDes), dan mitra bibit ikan di Kecamatan Siak Kecil (mitra kunci).

\section{Kanvas model bisnis wanatani nanas}

Kelompok wanita di Desa Dompas merumuskan sebuah model bisnis wanatani nanas di Arena Aksi 2 (seluas 3,3 ha), yaitu budidaya nanas bersama dengan pohon multifungsi, termasuk tanaman kayu. Pada skema model bisnis (Gambar 3.9), kelompok wanita secara spesifik mengeksplorasi bisnis nanas. Kelompok wanita ini menyasar pelanggan akhir (segmen pelanggan) dengan menyampaikan berbagai macam produk segar dan olahan, misalnya buah, selai, manisan nanas, rujak, es buah, dan obat-obatan herbal. Produk-produk ini disampaikan kepada pelanggan dengan harga yang bersaing dan dirumuskan dengan melihat peluang pasar (proposisi nilai). Konsumen akhir yang dituju akan dicapai melalui jaringan penjual (saluran), dengan mengelola jaringan dan hubungan baik dengan penjual dan konsumen di pasar (hubungan pelanggan). 


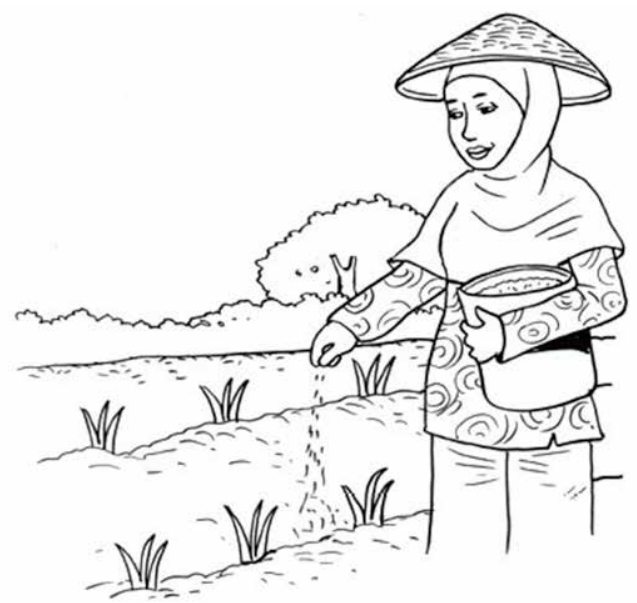

Gambar 3.8 Ilustrasi pemupukan lahan wanatani nanas.

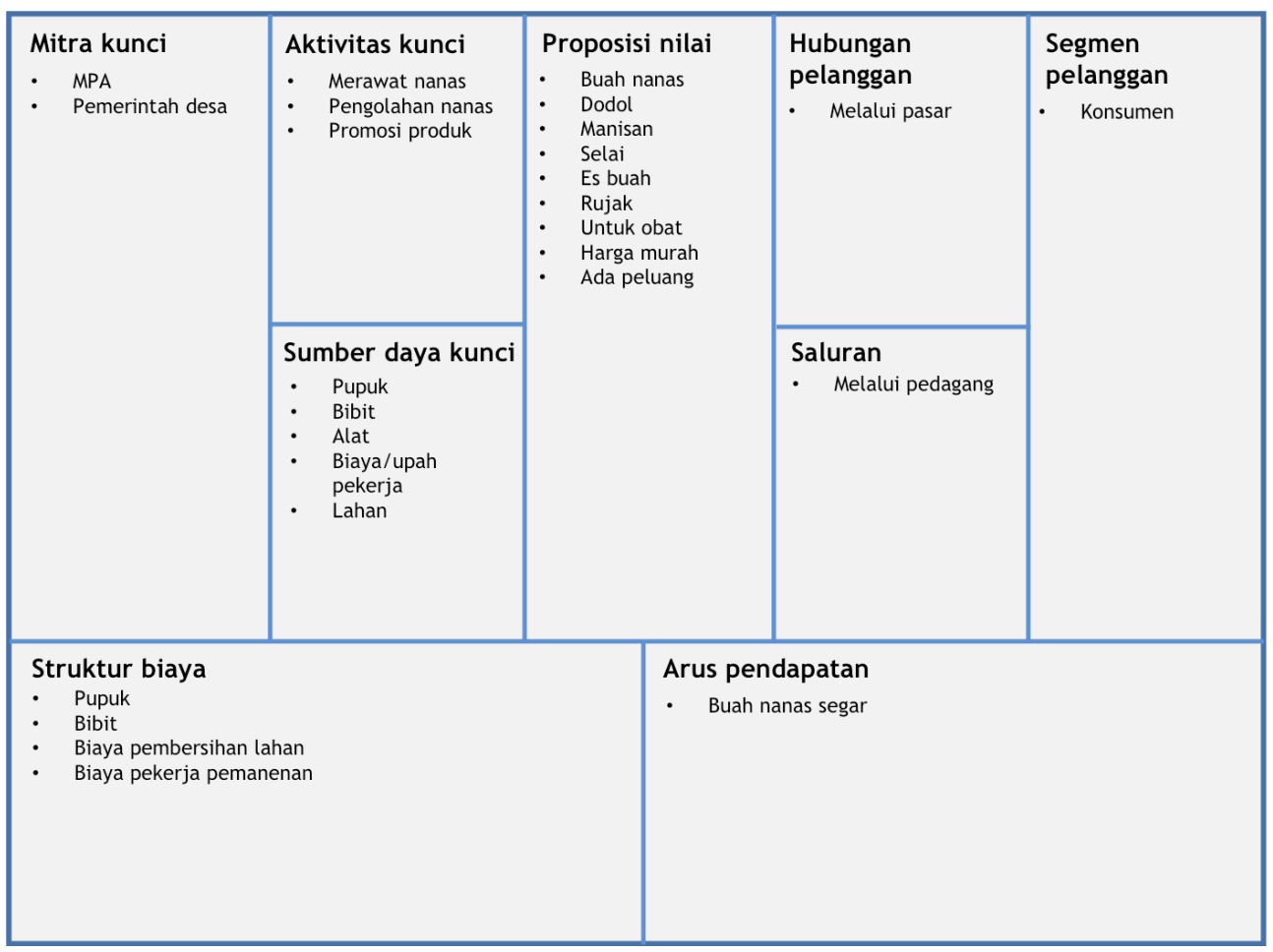

Gambar 3.9 Kanvas model bisnis untuk wanatani nanas yang dibuat oleh kelompok wanita di Arena Aksi 2. 
Model bisnis yang ada diharapkan untuk dapat menghasilkan pendapatan khususnya dari penjualan buah segar (arus pendapatan). Untuk merealisasikan pendapatan yang diharapkan, mereka harus berinvestasi pada pupuk, bibit nanas, peralatan pertanian, gaji pekerja dan yang paling penting adalah lahan (sumber daya kunci). Sejumlah sumber daya yang tersedia dikelola melalui serangkaian kegiatan, misalnya pengelolaan lahan wanatani nanas, pemeliharaan dan promosi produk (aktivitas kunci). Untuk melaksanakan aktivitas kunci dengan menggunakan sumber daya kunci, kelompok wanita memperkirakan beberapa biaya yang harus ditanggung, termasuk biaya untuk membeli bibit dan pupuk dan upah pekerja untuk pembersihan lahan dan panen (struktur biaya). Selanjutnya, MPA dan pemerintah desa diidentifikasi sebagai mitra kunci dalam model bisnisnya.

\section{Kanvas model bisnis wanatani kopi}

Kelompok keluarga petani di Desa Dompas yang mengelola Arena Aksi 4, 5, dan 6 merumuskan model bisnis kopi liberika (Gambar 3.11) yang menyasar perusahaan kopi, pelanggan dan spesialis penggiling kopi (segmen pelanggan). Mereka menawarkan biji kopi hijau dan juga kopi yang sudah dipanggang maupun digiling dalam kemasan yang menarik (proposisi nilai). Untuk mencapai konsumen yang dituju, mereka berharap untuk dapat memasarkan produk-produk mereka melalui sejumlah kafe dan juga langsung ke pabrik kopi (saluran). Komunikasi dengan para pelanggan akan dipertahankan melalui komunikasi yang baik dan berkesinambungan, dan juga melalui insentif-insentif misalnya menawarkan harga diskon (hubungan pelanggan). Sebagian besar dari pendapatan ini diproyeksikan berasal dari penjualan bibit kopi

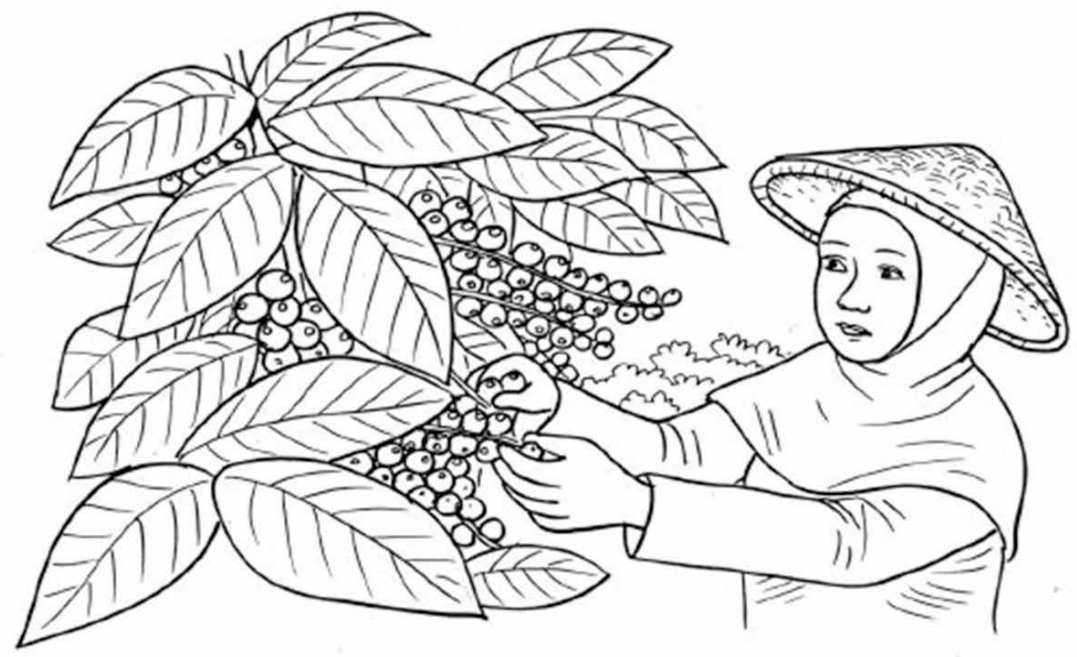

\section{Gambar 3.10 Ilustrasi pemanenan kopi.}




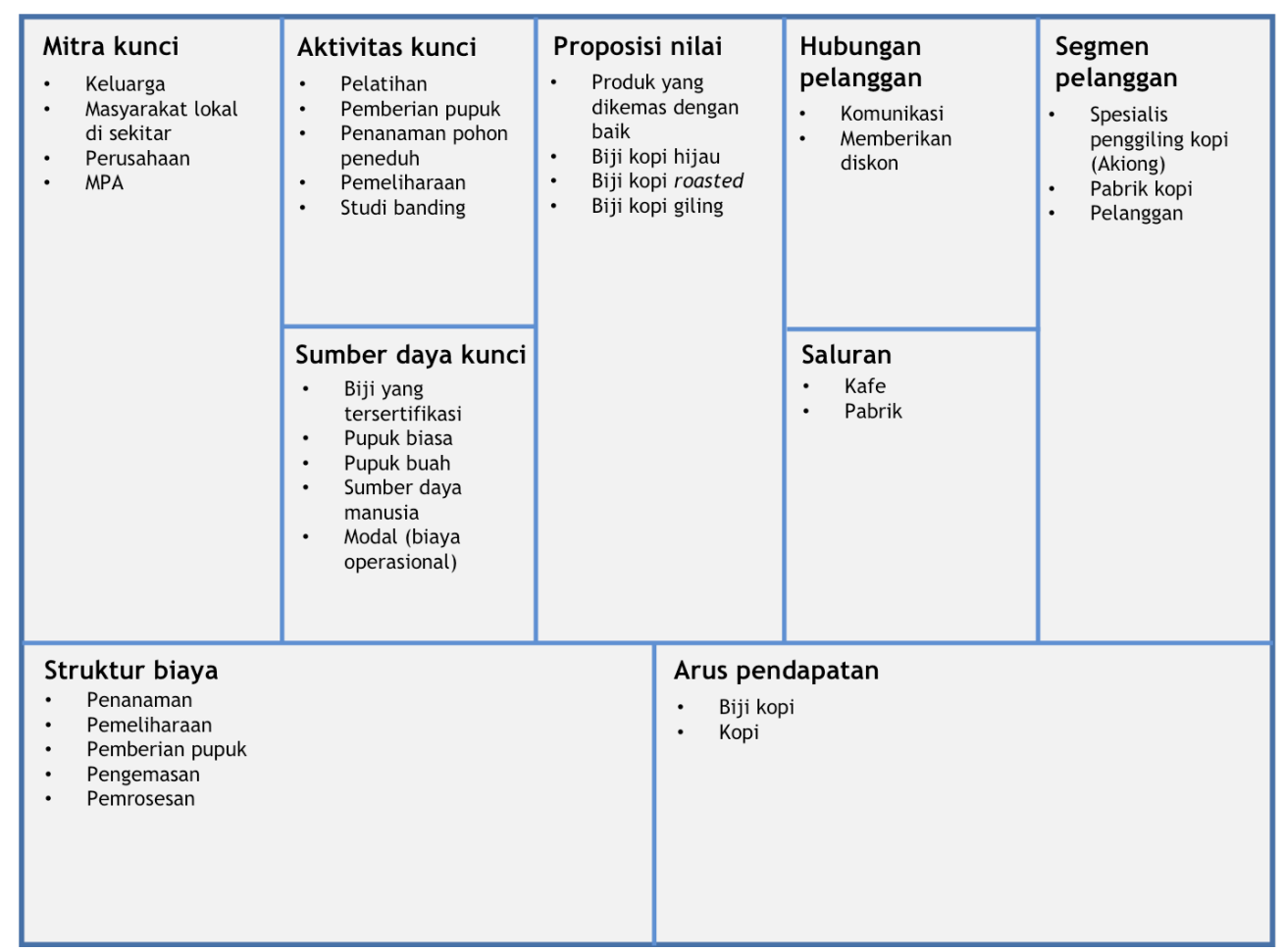

Gambar 3.11 Kanvas model bisnis kopi liberika yang dirumuskan oleh kelompok keluarga petani pengelola Arena Aksi 4, 5, dan 6.

yang tersertifikasi dan penjualan kopi (arus pendapatan). Dengan menggunakan sumber daya seperti bibit kopi tersertifikasi, pupuk, sumber daya manusia dan modal finansial (sumber daya kunci), kelompok keluarga petani akan melaksanakan aktivitas kunci seperti pelatihan, penanaman pohon naungan, pemupukan, pemeliharaan dan studi banding. Biaya-biaya seperti penanaman, pemeliharaan, pengemasan dan pemrosesan diidentifikasi sebagai biaya-biaya penting dalam model bisnis (struktur biaya). Mereka berharap dapat bermitra dengan kelompok keluarga (internal) dan juga masyarakat lokal, perusahaan swasta dan MPA, selaku mitra eksternal (mitra kunci).

\subsubsection{Gambaran langkah selanjutnya}

Tidak ada satu resep mujarab untuk bisnis yang sukses. Masyarakat harus menguji model bisnis yang dirumuskan di lapangan menggunakan skala bisnis nyata yang dipandu oleh rencana aksi. Dengan mempertimbangkan konteks, tujuan dan jangka waktu RAP, kami memfasilitasi diskusi lanjutan bersama dengan para pemangku kepentingan 
dan pejabat pemerintah daerah, pemilik tanah, dan masyarakat. Termasuk dalam topik diskusi adalah peran masing-masing aktor yang berpartisipasi serta identifikasi potensi dan tantangan yang muncul. Dengan menggunakan pendekatan partisipatif, masyarakat mulai merefleksikan dan menyampaikan aspirasi mereka tentang siapa yang dianggap sebagai aktor dan mitra penting, serta peran dan tanggung jawab masing-masing. Mereka juga mengidentifikasi tantangan atau kendala yang berpotensi muncul dalam mewujudkan bisnis bersama, berikut solusi untuk menghadapi hal tersebut. Masyarakat kemudian menentukan rencana aksi dan jadwalnya. Hal yang terpenting adalah bahwa diskusi ini menghasilkan komitmen antara pemerintah desa, pemilik tanah, masyarakat, dengan CIFOR dan PSB UNRI sebagai fasilitator.

Inti dari model bisnis dan perencanaan aksi atau tindakan yang baik terletak pada bagaimana model bisnis itu dapat diimplementasikan, dipantau dan dievaluasi secara berkelanjutan, untuk selanjutnya dapat dilakukan refleksi dan penyempurnaan model bisnis. Pendanaan dari Temasek Foundation memungkinkan masyarakat untuk melalui proses-proses ini selama periode 2018 hingga 2019. Secara total, kelompok berbasis masyarakat telah mengelola area seluas 11,1 ha, yaitu Arena Aksi 1-6 (tidak termasuk lahan pekarangan, yaitu Arena Aksi 7), dengan pedoman model bisnis dan rencana aksi. Pemantauan senantiasa dilakukan terhadap tantangan dan peluang yang terjadi agar dapat menjadi pembelajaran yang disebarluaskan kepada masyarakat lain. Pemantauan yang berkesinambungan juga penting untuk penyempurnaan model bisnis di masa depan. Penjelasan secara rinci terkait dengan proses riset aksi partisipatif dan pemantauan partisipatif berbasis teknologi informasi tersedia pada bab-bab lain yang ada di buku ini.

\subsection{MODEL BISNIS BERKELANJUTAN BAGI MASYARAKAT UNTUK PENCEGAHAN KEBAKARAN DAN RESTORASI GAMBUT}

Model bisnis yang dikembangkan melalui proses RAP di Desa Dompas, Bengkalis Provinsi Riau telah diujicobakan pada lahan seluas 11,1 ha dan sedang dalam proses pemantauan dan evaluasi. Pada tahapan (loop) kedua proses RAP, hasil dari pemantauan dan evaluasi akan digunakan untuk memperbaiki model bisnis yang telah diujicobakan. Dengan menggunakan proses RAP di Desa Dompas sebagai studi kasus, kami menarik beberapa poin penting sebagai berikut:

1. Model bisnis komoditas berbasis lahan gambut harus mempertimbangkan kegiatan pra-produksi, yaitu Penyiapan Lahan Tanpa Bakar (PLTB). Penting untuk menekankan adopsi PLTB ini pada masyarakat untuk mencegah subsidensi gambut dan menghindari gangguan pada fungsi hidrologisnya. Selain itu, memisahkan kegiatan kunci berdasarkan jangka waktu/durasi tertentu (sebelum, selama dan pasca produksi) akan memungkinkan identifikasi kegiatan maupun sumber daya yang diperlukan secara lebih terperinci. 
2. Banyak program dan intervensi yang menetapkan target kelompok berbasis masyarakat untuk menjangkau masyarakat yang lebih luas sembari membangun aksi kolektif di tingkat masyarakat. Program dan intervensi terkait restorasi lahan gambut serta topik-topik lain seperti program kesejahteraan keluarga, program inkubator bisnis dan lainnya menekankan penerima manfaat secara berkelompok daripada individu. Perancang dan pelaksana program perlu memikirkan tentang bagaimana manfaat dan biaya dibagi di antara para peserta untuk memastikan distribusi yang berkeadilan.

3. Terdapat variasi jenis barang dan jasa bervariasi, baik yang nyata maupun tidak nyata, misalnya ekowisata dan penyerapan dan/atau penyimpanan karbon dari pemulihan lahan gambut yang terdegradasi. Pengenalan dan pengakuan jenis barang dan jasa ini penting untuk mendidik dan meningkatkan kesadaran masyarakat tentang nilai penting dan manfaat ekosistem yang dilindungi.

4. Aspek kelestarian harus diakui sebagai proposisi nilai (value proposition) penting dalam model bisnis yang dirumuskan. Tercakupnya prinsip kelestarian dalam praktik diperlukan untuk mendapatkan citra merek yang positif, serta untuk menjangkau pasar-pasar baru dengan konsumen yang sadar lingkungan.

5. Memperkenalkan dan mengedukasi masyarakat tentang perumusan model bisnis adalah latihan yang baik untuk mendorong mereka bertukar gagasan. Diperlukan lebih banyak pertanyaan lanjutan untuk mengeksplorasi topik-topik tertentu secara lebih detail dengan mengoptimalkan waktu diskusi untuk membangun keterlibatan dan kolaborasi dalam kelompok.

6. Partisipasi dan curah gagasan dari masyarakat harus dihargai. Penting bagi masyarakat untuk bertukar pikiran (brainstorming) tentang sejumlah ide dan gagasan, kemudian memutuskan dan merumuskan model bisnis untuk diuji di lapangan. Pada tahap selanjutnya, pemantauan dan evaluasi dalam implementasi perlu dilakukan secara intensif.

Berkenaan dengan temuan-temuan tersebut, kami mengembangkan sebuah model yang mengadopsi BMC (Osterwalder dan Pigneur 2010) dan mempertimbangkan TLBMC (Joyce dan Paquin 2016) dan CBMPT (Nußholz 2018). Kami memadukannya dengan elemen yang terpenting, yaitu pembelajaran dari implementasi di tingkat lokal dengan kelompok-kelompok berbasis masyarakat. Gambar 3.12 menunjukkan skema Model Bisnis Berkelanjutan bagi Masyarakat atau Sustainable Business Model for Community (SBMC), yang khusus dirancang untuk pencegahan kebakaran dan restorasi di lahan gambut.

SBMC sangat bergantung pada pendekatan partisipatif dengan fokus intervensi di tingkat kelompok masyarakat. Dengan demikian, SBMC menekankan transparansi mekanisme pembagian biaya-manfaat dalam kelompok. Struktur biaya dan aliran 


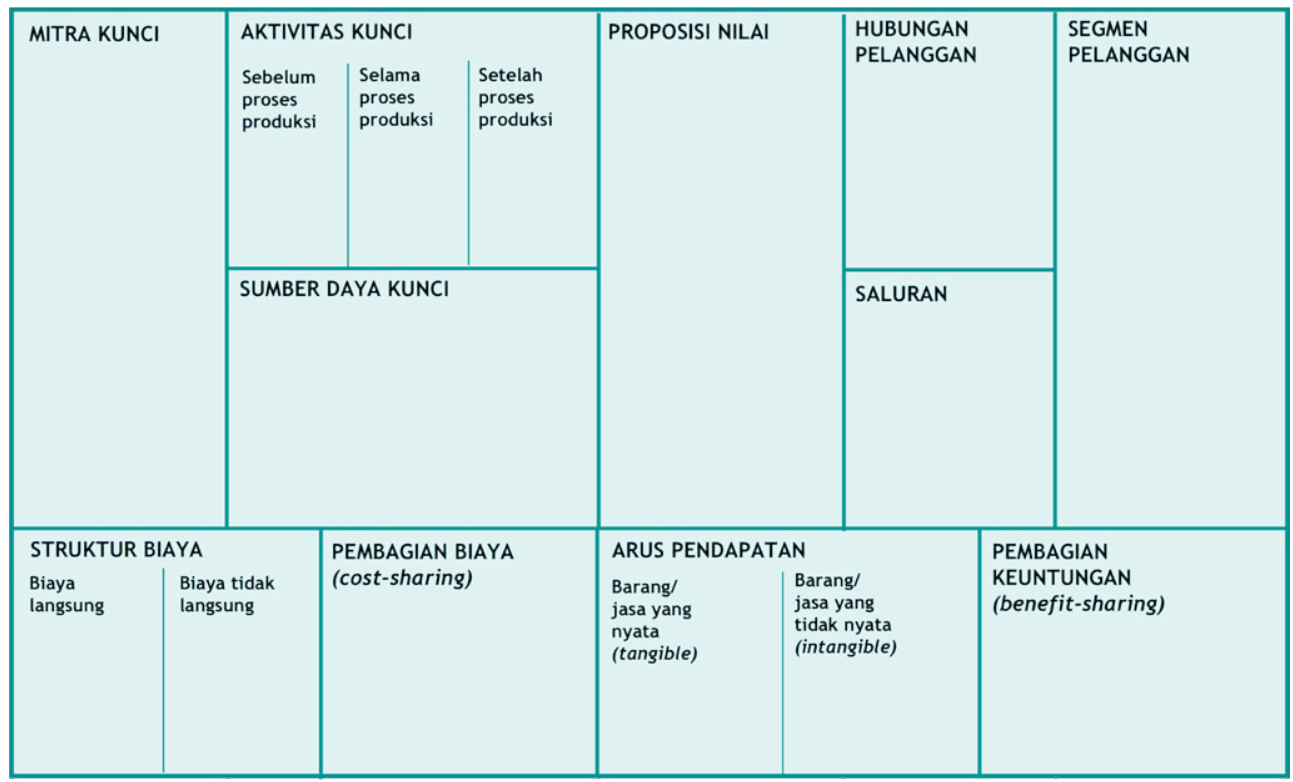

\section{Gambar 3.12 Model Bisnis Berkelanjutan bagi Masyarakat atau Sustainable Business Model for Community (SBMC) untuk pencegahan kebakaran dan restorasi gambut.}

pendapatan didefinisikan ulang dengan mengakui adanya biaya langsung dan tidak langsung serta barang dan jasa berwujud dan tidak berwujud. Kegiatan utama didefinisikan secara lebih rinci dengan mengklasifikasikan periode waktu. Sebagai rangkuman, tiga pilar penting yang membangun gagasan SBMC adalah: partisipatif, berkelanjutan, dan transparan bagi kelompok masyarakat di tingkat lokal.

\subsubsection{Pertanyaan panduan untuk SBMC}

Tabel 3.1 menunjukkan berbagai tujuan dan pertanyaan panduan untuk mengisi komponen SBMC. Setiap komponen saling berhubungan, misalnya kegiatan utama terkait dengan sumber daya utama, kemudian juga dihubungkan dengan perhitungan manfaat-biaya bisnis. Penting memahami bagaimana masing-masing komponen bekerja dan terhubung satu sama lain untuk memfasilitasi dan memandu proses bertukar pikiran dan diskusi. 
Tabel 3.1 Komponen, tujuan dan pertanyaan panduan untuk setiap komponen dalam SBMC.

\begin{tabular}{|c|c|c|}
\hline Komponen & Tujuan & Pertanyaan panduan \\
\hline Mitra kunci & $\begin{array}{l}\text { Mengidentifikasi mitra kunci } \\
\text { dan perannya. }\end{array}$ & $\begin{array}{l}\text { 1. Siapa mitra kunci potensial dalam } \\
\text { mengembangkan bisnis? } \\
\text { 2. Apa peran masing-masing mitra kunci? }\end{array}$ \\
\hline $\begin{array}{l}\text { Aktivitas } \\
\text { kunci } \\
\text { (sebelum, } \\
\text { selama, dan } \\
\text { sesudah } \\
\text { produksi). }\end{array}$ & $\begin{array}{l}\text { Mengidentifikasi kegiatan } \\
\text { sebelum, selama, } \\
\text { dan pasca produksi. } \\
\text { Memperkenalkan dan } \\
\text { meningkatkan kesadaran } \\
\text { tentang persiapan lahan } \\
\text { tanpa bakar, terutama untuk } \\
\text { mengembangkan komoditas } \\
\text { berbasis lahan di lahan } \\
\text { gambut. Memperkenalkan } \\
\text { dan mengidentifikasi opsi } \\
\text { untuk meminimalkan atau } \\
\text { memanfaatkan limbah. }\end{array}$ & $\begin{array}{l}\text { 1. Apa saja kegiatan sebelum, selama, } \\
\text { dan sesudah produksi yang } \\
\text { dibutuhkan? } \\
\text { 2. Apakah masing-masing kegiatan } \\
\text { ini membutuhkan persiapan lahan } \\
\text { menggunakan api atau mengeringkan } \\
\text { lahan gambut, atau alat berat? } \\
\text { 3. Apa dampaknya terhadap lahan } \\
\text { gambut jika aktivitasnya membutuhkan } \\
\text { penggunaan api atau mesin berat atau } \\
\text { proses pengeringan? } \\
\text { 4. Apa alternatif yang paling potensial } \\
\text { untuk mempertahankan lahan gambut? } \\
\text { 5. Apakah ada kegiatan utama yang } \\
\text { berpotensi meminimalkan atau } \\
\text { memanfaatkan limbah dari proses } \\
\text { produksi? }\end{array}$ \\
\hline $\begin{array}{l}\text { Sumber } \\
\text { daya kunci }\end{array}$ & $\begin{array}{l}\text { Mengidentifikasi sumber } \\
\text { daya utama yang diperlukan } \\
\text { untuk mengoperasikan } \\
\text { model bisnis. Brainstorming } \\
\text { tindakan yang diperlukan } \\
\text { untuk memastikan sumber } \\
\text { daya utama digunakan } \\
\text { secara efektif dan efisien. }\end{array}$ & $\begin{array}{l}\text { 1. Apa sumber daya utama yang } \\
\text { diperlukan untuk mewujudkan kegiatan } \\
\text { utama? } \\
\text { 2. Apakah ada ancaman yang dapat } \\
\text { menghambat kelestarian pasokan } \\
\text { bahan baku? } \\
\text { 3. Apa tindakan atau rencana yang } \\
\text { diperlukan untuk memastikan } \\
\text { penggunaan sumber daya utama } \\
\text { secara efisien dan efektif? }\end{array}$ \\
\hline
\end{tabular}


Tabel 3.1 Sambungan

\begin{tabular}{|c|c|c|}
\hline Komponen & Tujuan & Pertanyaan panduan \\
\hline $\begin{array}{l}\text { Proposisi } \\
\text { nilai }\end{array}$ & $\begin{array}{l}\text { Mengidentifikasi proposisi } \\
\text { nilai yang ditawarkan ke } \\
\text { segmen pelanggan. }\end{array}$ & $\begin{array}{l}\text { 1. Apa nilai-nilai yang perlu dan ingin } \\
\text { dibayar oleh pelanggan? } \\
\text { 2. Bagaimana masing-masing nilai } \\
\text { berbeda dengan yang ditawarkan oleh } \\
\text { pesaing? } \\
\text { 3. Apakah nilai yang diajukan mengakui } \\
\text { prinsip dan praktik kelestarian? } \\
\text { 4. Bagaimana prinsip dan praktik } \\
\text { kelestarian membedakan nilai yang } \\
\text { diusulkan dari pesaing? } \\
\text { 5. Apa rencana tindak lanjut dan strategi } \\
\text { yang diperlukan? }\end{array}$ \\
\hline $\begin{array}{l}\text { Hubungan } \\
\text { pelanggan }\end{array}$ & $\begin{array}{l}\text { Mengidentifikasi strategi } \\
\text { dan pendekatan untuk } \\
\text { menjaga hubungan dengan } \\
\text { segmen pelanggan. }\end{array}$ & $\begin{array}{l}\text { Apa tindakan dan strategi yang diperlukan } \\
\text { untuk menjaga hubungan dengan } \\
\text { pelanggan? }\end{array}$ \\
\hline Saluran & $\begin{array}{l}\text { Mengenali saluran yang } \\
\text { akan digunakan sebagai } \\
\text { sarana untuk menjangkau } \\
\text { segmen pelanggan. }\end{array}$ & $\begin{array}{l}\text { Saluran apa yang mungkin digunakan } \\
\text { untuk menjangkau pelanggan? }\end{array}$ \\
\hline $\begin{array}{l}\text { Segmen } \\
\text { pelanggan }\end{array}$ & $\begin{array}{l}\text { Mengidentifikasi pelanggan } \\
\text { maupun pangsa pasar } \\
\text { yang ingin dituju, sesuai } \\
\text { dengan proposisi nilai akan } \\
\text { disampaikan. }\end{array}$ & $\begin{array}{l}\text { 1. Siapa saja pelanggan yang dituju yang } \\
\text { bersedia membayar untuk nilai yang } \\
\text { ditawarkan oleh produsen? } \\
\text { 2. Siapa pelanggan potensial atau pasar } \\
\text { yang mungkin bersedia membayar } \\
\text { harga lebih tinggi (premium price) } \\
\text { untuk produk yang berkelanjutan? } \\
\text { 3. Seperti apakah preferensi pelanggan? } \\
\text { Apakah proposisi nilai yang diajukan } \\
\text { sudah sesuai untuk segmen pelanggan } \\
\text { yang ingin dituju? }\end{array}$ \\
\hline $\begin{array}{l}\text { Struktur } \\
\text { biaya } \\
\text { langsung }\end{array}$ & $\begin{array}{l}\text { Mengidentifikasi biaya yang } \\
\text { secara langsung diperlukan } \\
\text { untuk memproduksi barang/ } \\
\text { jasa. }\end{array}$ & $\begin{array}{l}\text { Biaya apa yang diperlukan secara } \\
\text { langsung untuk mendukung bisnis? }\end{array}$ \\
\hline
\end{tabular}


Tabel 3.1 Sambungan

\begin{tabular}{|c|c|c|}
\hline Komponen & Tujuan & Pertanyaan panduan \\
\hline $\begin{array}{l}\text { Struktur } \\
\text { biaya tidak } \\
\text { langsung }\end{array}$ & $\begin{array}{l}\text { Mengidentifikasi biaya } \\
\text { yang secara tidak } \\
\text { langsung diperlukan untuk } \\
\text { memproduksi barang / jasa; } \\
\text { tetapi secara substansial } \\
\text { berkontribusi untuk } \\
\text { menciptakan lingkungan } \\
\text { yang memungkinkan } \\
\text { produksi/ bisnis. Dalam } \\
\text { konteks restorasi gambut, } \\
\text { biaya tidak langsung ini } \\
\text { termasuk biaya patroli } \\
\text { pencegahan kebakaran } \\
\text { dan pemadaman kebakaran } \\
\text { serta biaya pembuatan } \\
\text { sekat kanal untuk menjaga } \\
\text { gambut tetap basah. }\end{array}$ & $\begin{array}{l}\text { 1. Apa saja biaya yang secara tidak } \\
\text { langsung diperlukan tetapi penting } \\
\text { untuk mendukung kelanjutan bisnis? } \\
\text { 2. Apakah ada kegiatan mitigasi bencana } \\
\text { (misalnya kebakaran dan kabut asap } \\
\text { berulang) yang perlu dicakup oleh } \\
\text { bisnis? }\end{array}$ \\
\hline $\begin{array}{l}\text { Pembagian } \\
\text { biaya dalam } \\
\text { kelompok }\end{array}$ & $\begin{array}{l}\text { Mengidentifikasi mekanisme } \\
\text { pembagian biaya dalam } \\
\text { kelompok. }\end{array}$ & $\begin{array}{l}\text { 1. Bagaimana biaya langsung dan tidak } \\
\text { langsung dibagi dalam kelompok? } \\
\text { 2. Bagaimana mitra utama akan } \\
\text { membantu pembayaran untuk biaya } \\
\text { atau akses ke pendanaan? }\end{array}$ \\
\hline $\begin{array}{l}\text { Arus } \\
\text { pendapatan } \\
\text { dari barang/ } \\
\text { jasa yang } \\
\text { berwujud. }\end{array}$ & $\begin{array}{l}\text { Mengidentifikasi proyeksi, } \\
\text { potensi pendapatan dari } \\
\text { barang/ jasa berwujud. }\end{array}$ & $\begin{array}{l}\text { 1. Apa saja barang dan jasa berwujud } \\
\text { yang berpotensi menghasilkan laba? } \\
\text { 2. Apakah penerimaan yang dihasilkan } \\
\text { dari barang dan jasa berwujud yang } \\
\text { teridentifikasi lebih besar dari biaya } \\
\text { yang dikeluarkan? } \\
\text { 3. Apa strategi untuk menghasilkan laba } \\
\text { maksimal? }\end{array}$ \\
\hline $\begin{array}{l}\text { Arus } \\
\text { pendapatan } \\
\text { untuk } \\
\text { barang/ } \\
\text { jasa tidak } \\
\text { berwujud }\end{array}$ & $\begin{array}{l}\text { Mengidentifikasi potensi } \\
\text { pendapatan yang } \\
\text { diproyeksikan dari barang/ } \\
\text { jasa tidak berwujud. }\end{array}$ & $\begin{array}{l}\text { 4. Apa saja barang/jasa tidak berwujud } \\
\text { yang potensial? (misalnya, ekowisata } \\
\text { dan karbon) } \\
\text { 5. Apa strategi untuk mulai menjual } \\
\text { barang/ jasa tidak berwujud? }\end{array}$ \\
\hline $\begin{array}{l}\text { Pembagian } \\
\text { manfaat } \\
\text { dalam } \\
\text { kelompok }\end{array}$ & $\begin{array}{l}\text { Identifikasi mekanisme } \\
\text { pembagian manfaat dalam } \\
\text { kelompok. }\end{array}$ & $\begin{array}{l}\text { 6. Apa manfaat finansial dan non-finansial } \\
\text { dari model bisnis? } \\
\text { 7. Bagaimana manfaat ini dibagikan } \\
\text { dan bagaimana memastikan } \\
\text { pembagiannya adil? }\end{array}$ \\
\hline
\end{tabular}




\subsection{KESIMPULAN}

Pengembangan model bisnis berkelanjutan bagi masyarakat (SBMC) mengadopsi prinsip-prinsip yang sudah ada, digabungkan dengan pemahaman pada konteks sosioekologi secara sistematis sangat penting untuk mendukung scaling-up dan replikasi di lokasi lainnya. Hal ini juga akan memungkinkan kelompok masyarakat untuk melatih cara berpikir sistematis dalam langkah-langkah yang didefinisikan dengan jelas. Latihan ini akan memungkinkan mereka menangkap gambaran besar dan merumuskan strategi yang diperlukan. Khusus untuk mendukung pencegahan kebakaran dan restorasi gambut, model bisnis harus dirancang sedemikian rupa sehingga memungkinkan masyarakat memiliki pilihan mata pencaharian berkelanjutan sembari memulihkan lahan gambut yang terdegradasi. Penting pula untuk merumuskan model bisnis yang dapat dikerjakan dan diujicoba oleh masyarakat. Kesuksesan implementasi model bisnis berbasis masyarakat ini diharapkan dapat menghasilkan manfaat triple bottom line yang dapat membantu masyarakat berkembang dan melangkah maju secara mandiri, selain juga berkontribusi pada pembangunan yang berkelanjutan.

\subsection{PUSTAKA}

Berns M, Towend A, Khayat Z, Balagopal B, Reeves M, Hopkins MS, dan Kruschwitz. 2009. Sustainability and competitive advantage, MIT Sloan Management Review, 51(1): 19-26.

Bocken NMP, Short SW, Rana P, dan Evans S. 2014. A literature and practice review to develop sustainable business model archetypes. Journal of Cleaner Production, 65: 42-56.

Boons F, Montalvo C, Quist J, dan Wagner M. 2013. Sustainable innovation, business models and economic performance: an overview. Journal of Cleaner Production, 45: 1-8.

Cantele S dan Zardini A. 2018. Is sustainability a competitive advantage for small businesses? An empirical analysis of possible mediators in the sustainabilityfinancial performance relationship. Journal of Cleaner Production,182:166-176.

Dommain R, Dittrich I, Giessen W, Joosten H, Rais DS, Silvius M, dan Wibisono, I.T. 2016. Ecosystem services, degradation and restoration of peat swamps in the South East Asian tropics. Dalam Bonn A, Allott T, Evans M, Joosten H, dan Stoneman R, eds. Peatland restoration and ecosystem. Cambridge, UK: Cambridge University Press. 253-288.

Esslinger H. 2011. Sustainable design: beyond the innovation-driven business model. Journal of Production Innovation Management, 28: 401-404. 
Elkington J. 1994. Towards the sustainable corporation: win-win-win business strategies for sustainable development. California Management Review, 36(2): 90-100.

Evans S, VladimirovaD, Holgado M, Van Fossen K, Yang M, Silva EA, dan Barlow CY. 2017. Business model innovation for sustainability: towards a unified perspective for creation of sustainable business models. Business Startegy and the Environment, 26 (5): 597-608.

Geissdoerfer M, Vladimirova D, dan Evans S. 2018. Sustainable business model innovation: a review. Journal of Cleaner Production, 198: 401-416.

Hergoualc'h K, Hendry D, Murdiyarso D, dan Verchot, L. 2017. Total and heterotrophic soil respiration in a swamp forest and oil palm plantations on peat in Central Kalimantan, Indonesia. Biogeochemistry, 135(3): 203-220.

Ilham QP, Purnomo H, Rohadi D, dan Puspitaloka D. 2019. Value chain analysis for haze-free livelihoods in peatlands. Bogor, Indonesia: Center for International Forestry Research (CIFOR).

Joyce A dan Paquin RL. 2016. The triple layered business model canvas: a tool to design more sustainable business models. Journal of Cleaner Production, 135: 1474-1486.

Magretta J. 2002. Why business models matter. Harvard Business Review, 80(5): 86-92.

Meijaard E, Abram NK, Wells JA, Pellier A-S, Ancrenaz M, Gaveau DLA, Runting RK, dan Mengersen K. 2013. People's Perceptions about the Importance of Forests on Borneo. PLOS ONE, 8(9): e73008.

Nikolova A dan Mesiano R. 2018. Circular economy-making sustainability part of the solution Asia-Pacific. [diakses 10 November 2019]. https://www.unescap.org/blog/ circular-economy-making-sustainability-part-the-solution-asia-pacific

Nußholz JLK. 2018. Circular business model planning tool: a tool to help design business models that extend the useful life of products and materials and capitalize on the associated value. Lund, Sweden: International Institute for Industrial Environmental Economics (IIIEE), Lund University.

Osterwalder A dan Pigneur Y. 2010. Business model generation. Hoboken, New Jersey: John Wiley \& Sons.

Puspitaloka D. 2018. Restoring degraded tropical peatlands: case studies from Central Kalimantan, Indonesia. Flagstaff, Arizona: Northern Arizona University.

Resta B, Dotti S, Ciarapica FE, De Sanctis I, Fani V, Bandinelli R, dan Rinaldi R. 2017. Leveraging environmental sustainability for competitive advantage in Italian cloting and leather sector. International Journal of Fashion Design, Technology and Education, 11(2): 169-186.

Ritala P, Huotari P, Bocken N, Albareda L, dan Puumalainen K. 2018. Sustainable business model adoption among S\&P 500 firms a longitudinal content analysis study. Journal of Cleaner Production, 170: 216-226. 
Sarkis J. 1998. Theory and methodology evaluating environmentally conscious business practices. European Journal of Operational Research, 107: 159-174.

Teece DJ. 2010. Business models, business strategy, and innovation. Long Range Planning, 43(2-3): 172-194.

Teece DJ. 2018. Business models and dynamic capabilities. Long Range Planning, 51: 40- 49.

Wu Z dan Pagell M. 2011. Balancing priorities: decision-making in sustainable supply chain management. Journal of Operations Management, 29: 577-590. 



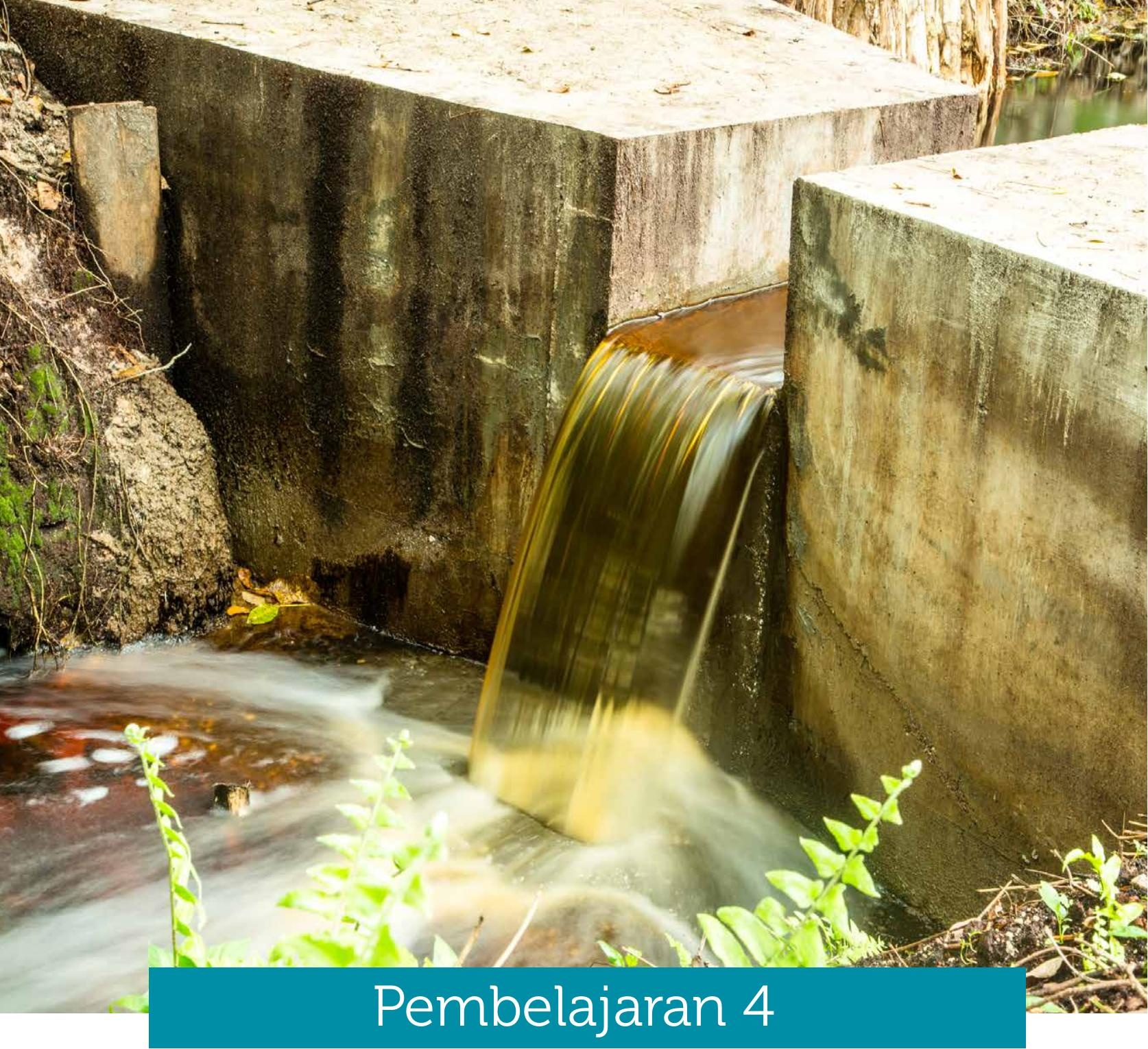

\section{Pembangunan Sekat Kanal dan Sistem Pemantauan Tinggi Muka Air Tanah}




\subsection{PENDAHULUAN}

Kebakaran besar hutan dan lahan di ekosistem gambut Indonesia telah terjadi pada musim kemarau tahun 1997 dan 2015. Salah satu penyebab utama terjadinya bencana tersebut adalah kondisi tinggi muka air (TMA) tanah di ekosistem gambut terdegradasi Pulau Sumatera dan Kalimantan, yang telah mengalami penurunan secara nyata dibandingkan kondisi alaminya, misalnya di ekosistem hutan gambut tropis Pulau Papua, Indonesia. Sistem drainase telah mengeringkan sebagian besar lahan gambut di Sumatera dan Kalimantan, yang meningkatkan risiko kebakaran dan banjir, serta mempercepat laju emisi karbon pada tingkat yang membahayakan kondisi iklim dunia. Korban jiwa dan biaya triliunan rupiah telah menjadi dampak dari terjadinya bencana tersebut. Berbagai upaya pemerintah dan lembaga-lembaga mitra pembangunan dengan dukungan dana internasional telah dikembangkan untuk dapat mencegah dan menanggulangi secara cepat terjadinya kebakaran di ekosistem gambut. Termasuk dalam upaya-upaya tersebut adalah pembangunan infrastruktur pembasahan gambut dan penanaman kembali jenis-jenis endemik gambut di wilayah yang terdegradasi dan menjadi target restorasi gambut. Bab ini merupakan rangkaian petunjuk mengenai pembangunan sekat kanal dan pemantauan dampak sekat kanal terhadap pembasahan lahan gambut.

Bab ini disusun berdasarkan hasil uji coba dan aplikasinya di Desa Dompas, Kecamatan Bukit Batu, Kabupaten Bengkalis, Riau. Wilayah tersebut dipilih dan disepakati oleh para pihak terkait kegiatan pencegahan kebakaran lahan gambut (Badan Restorasi Gambut, Pemerintah Daerah Kabupaten Bengkalis, perusahaan pemilik konsesi dan masyarakat) mengingat kebakaran hebat yang terjadi pada lokasi tersebut pada tahun 2015. Wilayah terpilih juga merupakan salah satu wilayah kecamatan dengan jumlah hotspot terbanyak pada tahun tersebut di Indonesia. Bab ini diharapkan akan dapat menjadi alat bantu dalam kegiatan pembangunan sekat kanal yang tidak saja berkualitas tinggi dan tahan lama, tetapi juga optimal dan dirasakan manfaatnya oleh berbagai pihak.

Pada bagian awal bab ini akan dijelaskan tentang apa, mengapa dan bagaimana proses pembangunan sekat kanal dan pemantauan tinggi muka air tanah, dari sudut pandang Riset Aksi Partisipatif (Participatory Action Research).

\section{- Apa?}

Pembangunan sekat kanal ditujukan untuk meningkatkan tinggi muka air tanah di wilayah sekitar lokasi sekat kanal. Kegiatan tersebut merupakan bagian dari agenda riset yang lebih besar dalam kerangka riset aksi partisipatif untuk pencegahan kebakaran di lahan gambut. Penelitian ini menggunakan konsep RAP yang terdiri dari beberapa fase, termasuk fase refleksi, rencana, aksi dan pemantauan. Semua kegiatan tersebut ditujukan untuk menurunkan risiko terjadinya kebakaran lahan gambut dan terjadinya emisi gas rumah kaca pada tingkat desa. 


\section{- Mengapa?}

Banyak kasus terjadinya kerusakan infrastruktur pembasahan yang telah dibangun akibat tidak baiknya perencanaan yang dilakukan serta tidak dilakukannya sosialisasi dan diskusi yang memadai tentang rencana pembangunannya. Sebagai akibatnya, tidak terdapat sinergi, kepercayaan dan kesepemahaman antara pihak pembangun sekat kanal dan para pihak di wilayah pembangunannya. Beberapa sekat kanal telah dengan sengaja dirusak oleh masyarakat yang terganggu aktivitas hidupnya sehari-hari. Hal ini menunjukkan bahwa sekat kanal tidak selayaknya dibangun dengan pendekatan top-down, dan sebaliknya harus menggunakan pendekatan yang mengutamakan proses partisipatif di antara para pihak setempat, khususnya yang terkait dengan kebakaran lahan gambut dan pembasahan kembali ekosistem gambut terdegradasi. RAP merupakan alternatif pilihan metode yang dapat digunakan untuk menghasilkan pembangunan sekat kanal yang berkualitas tinggi, optimal pemanfaatannya, dan diinginkan oleh mayoritas para pihak setempat (Gambar 4.1).

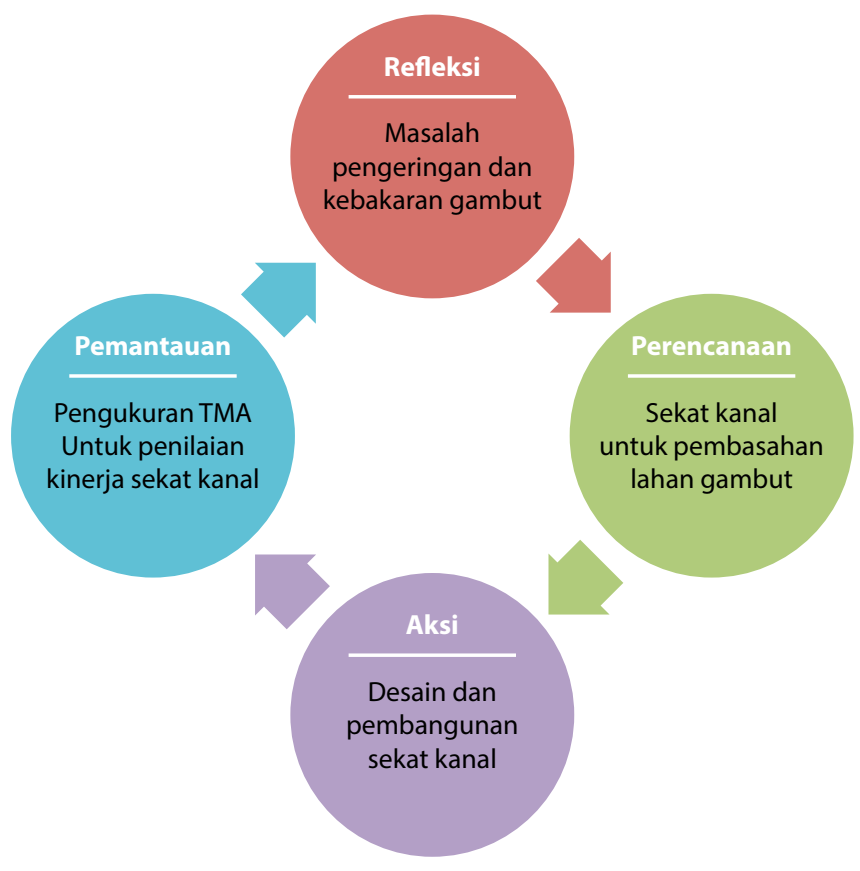

\footnotetext{
Gambar 4.1 Tahapan proses dalam RAP untuk pembangunan sekat kanal dalam penanggulangan masalah pengeringan dan kebakaran ekosistem gambut.
} 


\section{- Bagaimana?}

Riset aksi partisipatif (RAP) dapat dipraktekkan untuk memperoleh pemecahan masalah di lahan gambut secara lebih baik. Selama fase refleksi, sebagai contoh, masalah yang ditimbulkan oleh pembangunan sistem drainase gambut didiskusikan bersama dengan masyarakat dan elemen desa lainnya. Proses diskusi tersebut dapat menghasilkan cara pemecahan masalah yang dipilih dan disetujui bersama, misalnya pembangunan sekat kanal atau penimbunan kanal. Pada fase selanjutnya, yaitu fase perencanaan, suatu rencana pelaksanaan disusun untuk cara yang terpilih tersebut melalui forum diskusi, dengan peserta diskusi yang sama dengan tahap sebelumnya. Pada fase aksi sebagai tahap pelaksanaan rencana, dilakukan pembangunan sekat kanal dengan menggunakan metode yang telah disetujui dalam forum. Selanjutnya, pada fase pemantauan, kinerja sekat kanal dalam meningkatkan tinggi muka air tanah harus diukur dan dipantau untuk menghasilkan data. Data yang dikumpulkan pada fase pemantauan kemudian dianalisis untuk mengevaluasi keberhasilan atau kegagalan dari cara pemecahan masalah yang telah dipilih. Evaluasi ini merupakan tahap awal dari siklus riset aksi partisipatif berikutnya, yang akan menentukan apakah diperlukan perbaikan cara pemecahan masalah atau tidak. Apabila pemecahan masalah ternyata berjalan sesuai rencana, maka perlu direncanakan tindakan pengembangan atau perluasannya di wilayah lain.

\subsection{PEMBANGUNAN SEKAT KANAL}

\subsubsection{Fase refleksi}

Sangat perlu untuk diperhatikan bahwa sebelum bekerja intensif bersama masyarakat, keberadaan riset aksi partisipatif ini telah dikenal dan mendapat persetujuan mereka melalui serangkaian kegiatan, seperti prasurvei dan wawancara dengan para pimpinan dan tokoh di desa. Sebagai contoh, sebuah pertemuan telah diadakan oleh tim peneliti CIFOR dan Temasek Foundation (lembaga penyandang dana penelitian) di kantor Desa Dompas untuk secara resmi memperkenalkan kegiatan proyek pada staf desa dan masyarakat umum (Gambar 4.2). Dialog yang dilaksanakan tidak hanya terbatas dalam pertemuan tersebut, tetapi juga dalam kunjungan ke rumah tokoh Desa Dompas (Bapak Rozi, ketua Masyarakat Peduli Api/MPA), yang sekaligus menjadi tempat persemaian bibit pohon untuk kegiatan penanaman pohon dalam proyek ini. Dalam kegiatan ini, fase refleksi dilakukan dengan proses memahami tentang kondisi rusaknya lahan gambut akibat drainase dan kebakaran lahan serta proses yang dibutuhkan untuk mengatasinya. Salah satu caranya yaitu dengan penanaman pohon pada hutan rawa gambut. 


\subsubsection{Observasi awal kondisi penutupan lahan dan jaringan kanal}

Tim peneliti CIFOR, Singapore Cooperation Enterprise (SCE), dan masyarakat juga melakukan observasi lapangan dengan mengunjungi lokasi kebun karet dan sawit yang mendominasi penutupan lahan Desa Dompas. Kami melihat dan mendiskusikan tentang kebun kelapa sawit seluas 10 ha milik seorang tokoh desa, Bapak Atik, yang menjadi sosok sukses petani sawit dan karet di lahan gambut. Kami juga berbincang mengenai keberadaan kanal selebar 2 m yang telah ditimbun dengan gambut secara mandiri oleh beliau. Lahan ini dipertimbangkan sebagai lokasi yang akan dibasahi kembali dengan pembangunan sekat kanal dan dilakukan penanaman tambahan pohon-pohon hutan.

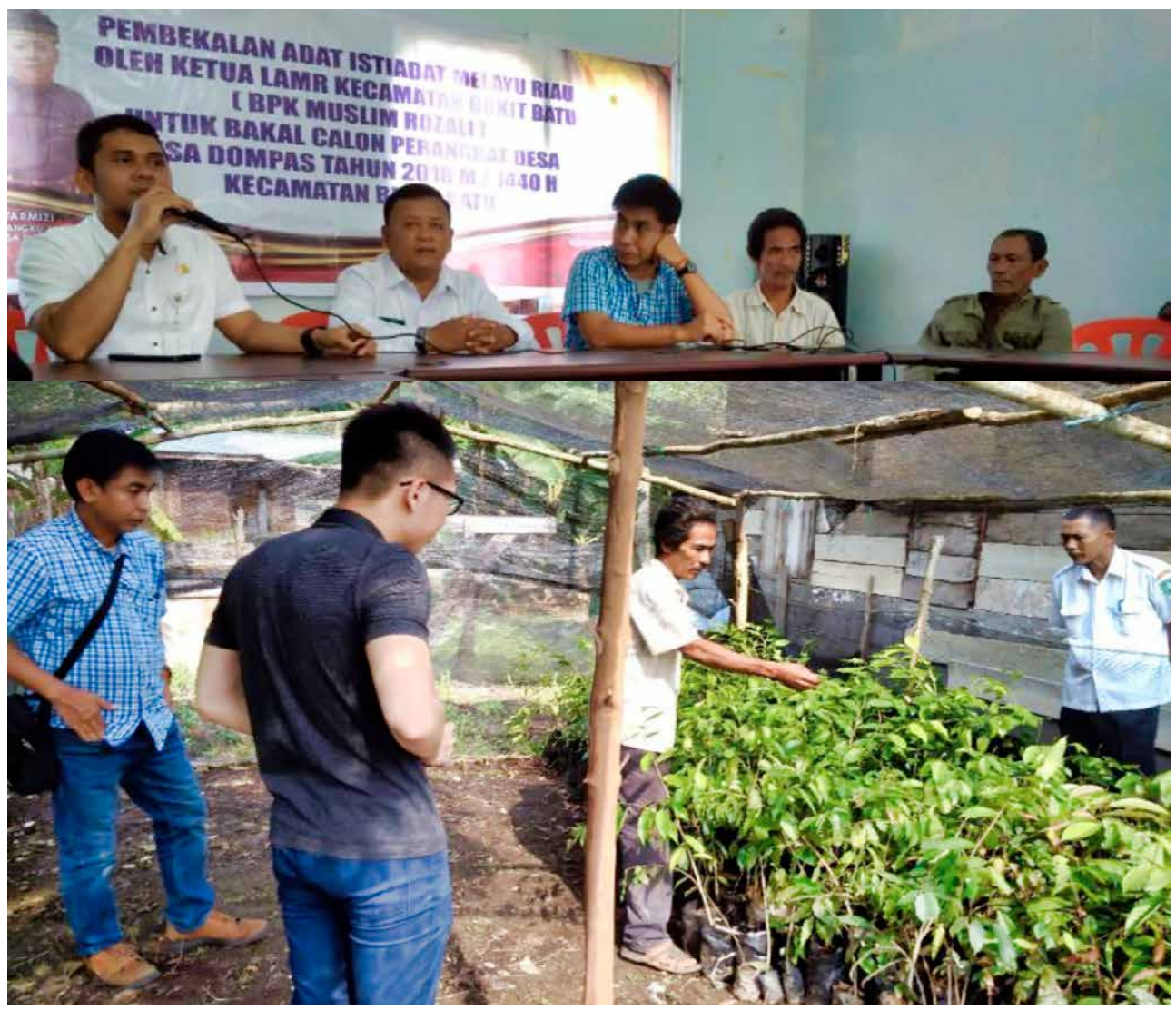

Gambar 4.2 Diskusi di kantor Desa Dompas (atas) dan kunjungan ke persemaian pohon hutan rawa gambut (bawah). 
Pengamatan juga dilakukan pada sebuah sekat kanal yang sekaligus menjadi jembatan penghubung antara lahan dengan jalan semen di dekatnya, yang menghubungkan para petani karet setempat dengan jalan lingkar provinsi sekitar $300 \mathrm{~m}$ di sebelah timur (Gambar 4.3). Di tengah lahan desa, tepatnya sekitar 200 m dari kanal, terdapat sebuah stasiun pengamatan tinggi muka air tanah otomatis (Sesame system) milik BRG yang telah dibangun sejak tahun 2018. Kemudian pengamatan dilanjutkan pada lokasi sekat kanal yang telah dibangun CIFOR sebelumnya, sekitar 500 m di sebelah barat lahan desa, yang terletak pada posisi yang relatif lebih tinggi dari posisi lahan desa. Kami melanjutkan perjalanan untuk melihat kanal yang lebih lebar dan dalam (dengan dasar tanah mineral) yang digali oleh pemegang konsesi perkebunan sawit di lahan gambut dan berbatasan langsung dengan lahan milik warga masyarakat. Kanal tersebut mengalirkan air keluar wilayah gambut ke sungai yang berada di sebelah utara, yang kemudian bermuara ke laut. Hal ini telah mengalihkan arah aliran air dalam lahan gambut yang semula mengarah ke lahan desa dan perkebunan karet masyarakat, yang berada di hilirnya, menjadi terbuang ke sungai. Selain itu, kami juga melakukan kunjungan ke wilayah desa dekat jalan provinsi yang bertanah mineral, berlumpur dan dipengaruhi oleh pasang surut air laut.

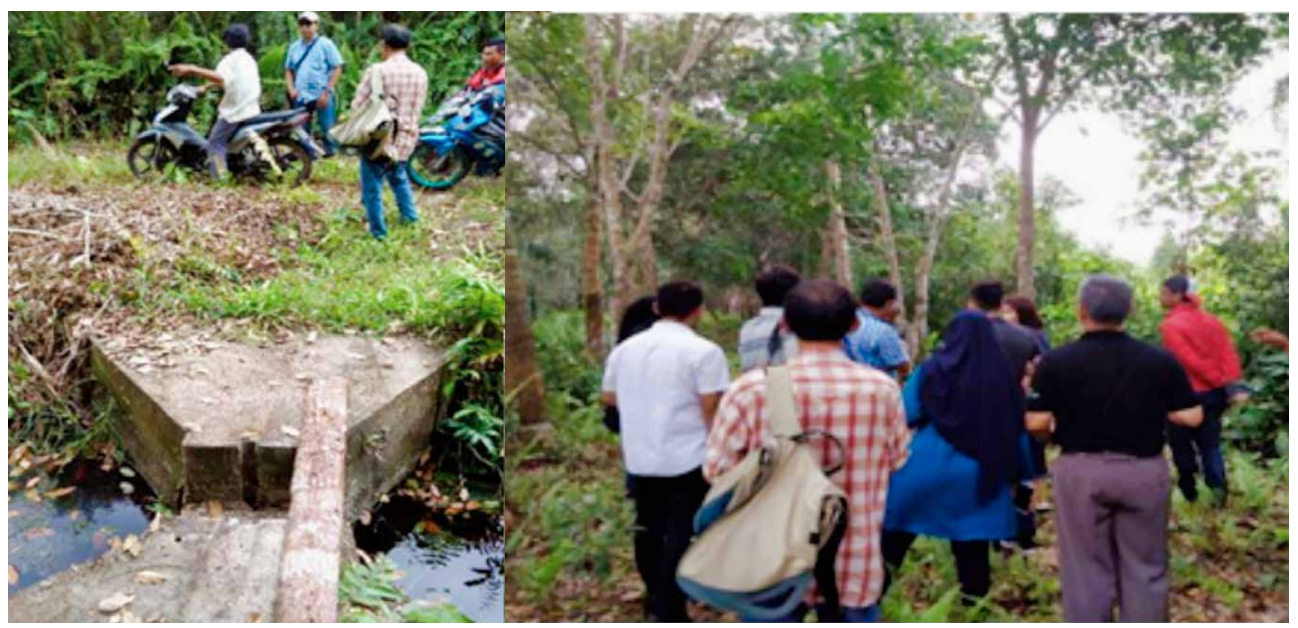

Gambar 4.3 Observasi awal kondisi penutupan lahan, jaringan kanal dan sekat kanal pada arena aksi di Desa Dompas. 
Pada fase refleksi, kondisi awal lahan gambut di wilayah penelitian dipelajari dan dikaji melalui kajian pustaka (literature review), pemetaan kedalaman gambut dan topografinya, serta pengambilan contoh tanah gambut. Kajian pustaka dilakukan dengan mengumpulkan peta-peta dasar mengenai wilayah penelitian yang tersedia dari berbagai sumber, terutama peta lahan gambut Indonesia dari Ritung dkk. (2011) dengan skala 1:250.000, peta Kesatuan Hidrologis Gambut/KHG dari Kementerian Lingkungan Hidup dan Kehutanan dengan skala yang sama, peta administrasi dan peta topografi dari Badan Informasi dan Geospasial. Peta-peta tersebut berisi informasi batas wilayah, sungai, jalan dan informasi ketinggian dari permukaan laut. Beberapa citra satelit juga dikumpulkan, untuk diproses dan menghasilkan informasi penutupan lahan dan model elevasi.

\subsubsection{Survei batas dan kedalaman gambut, topografi dan karakteristik lingkungan}

Untuk memperoleh informasi tambahan terkait lingkungan, kegiatan lapangan dilakukan bersama masyarakat dan anggota kelompok Masyarakat Peduli Api (MPA). Sebelum dan selama pelaksanaan kegiatan lapangan, pelatihan diberikan pada partisipan lokal yang telah dipilih dan disetujui sebelumnya oleh perangkat desa untuk mendampingi tim peneliti. Pelatihan tersebut dimaksudkan untuk meningkatkan kapasitas tim pendamping dan memastikan kualitas data-data lingkungan yang dikumpulkan, termasuk kedalaman gambut dan topografi.

Untuk kegiatan survei lapangan dan penentuan posisi di lokasi pengukuran digunakan aplikasi telepon genggam berbasis android dan ArcGis Collector (Gambar 4.4). Aplikasi ini merupakan bagian dari platform ESRI Geospatial Cloud yang dapat dimodifikasi sesuai kebutuhan penggunanya. Surveyor dapat menggunakan peta dalam jaringan (daring) pada telepon genggamnya untuk mengumpulkan dan menyunting data spasial selama survei di lapangan. Aplikasi tersebut dapat diunduh secara bebas melalui Google Apps store. Selanjutnya lapisan peta dapat diunggah ke dalam aplikasi untuk penggunaan di lapangan. Aplikasi tersebut dapat bekerja dengan baik dalam kondisi luring (tanpa jaringan internet). Aplikasi ini sejenis dengan aplikasi pemetaan lain yang lebih populer saat ini yaitu Avenza Maps.

Jalur untuk pengukuran topografi/perbedaan ketinggian tempat dibuat sepanjang batas lokasi-lokasi arena aksi, yang telah disepakati para pihak dalam kegiatan RAP. Jalur pengukuran perbedaan tinggi tempat dibuat dengan jarak antar titik pengukuran sejauh 25 m (direct levelling) ${ }^{3}$.

3 http://www.fao.org/tempref/FI/CDrom/FAO_Training/FAO_Training/General/x6707e/x6707e05.htm\#80 


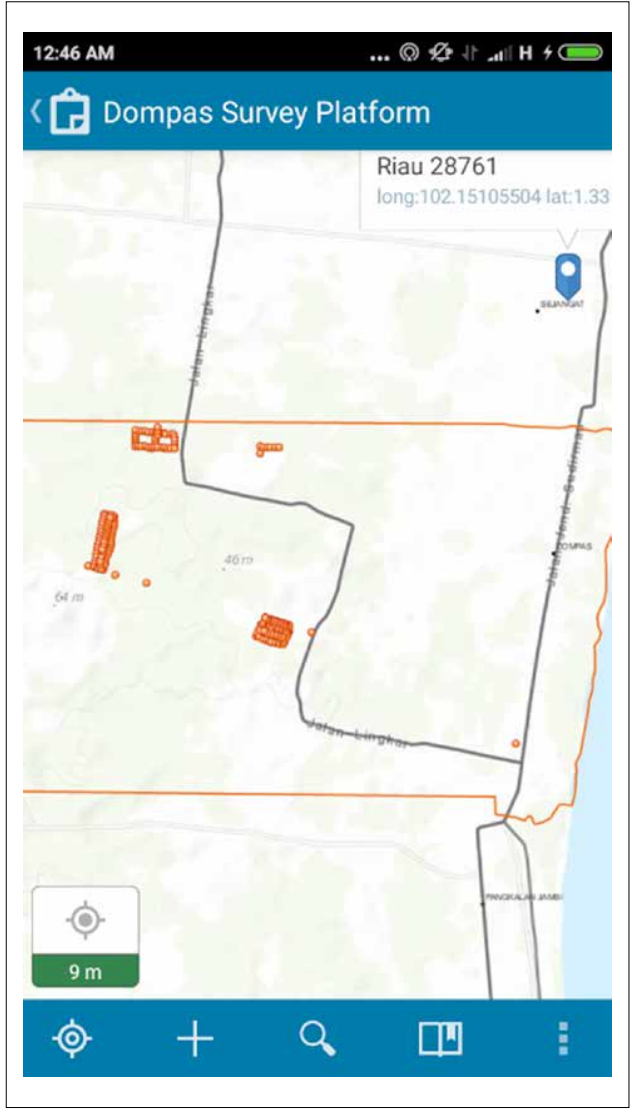

\section{Gambar 4.4 Contoh tampilan layar telepon genggam saat menggunakan aplikasi ArcGIS Collector yang menunjukkan lokasi arena aksi (simbol warna merah).}

Pengukuran perbedaan tinggi tempat dilakukan dengan mencatat ketinggian masing-masing ujung muka air, yang sudah dimasukkan dalam pipa plastik bening sepanjang 30 m dari permukaan tanah di bagian pangkal dan ujung pipa pada saat yang bersamaan. Dibutuhkan dua orang untuk mengaplikasikan metode ini, yang masing-masing bertugas memegang dan memposisikan ujung pipa di atas tanah, memperhatikan ujung muka air dalam pipa, dan mencatat ketinggian ujung muka air dalam pipa dari permukaan tanah. Pencatatan ketinggian muka air dalam pipa bagian ujung (yang dipegang surveyor \#2 pada jarak 25 m dari lokasi surveyor \#1) dilakukan ketika tinggi muka air pada pada bagian pangkal pipa (lokasi surveyor \#1) sudah mencapai ketinggian yang disepakati (misalnya $50 \mathrm{~cm}$ di atas permukaan tanah). Selisih tinggi muka air antara bagian pangkal dan ujung pipa air adalah juga perbedaan ketinggian tempat di antara dua lokasi tersebut. Jika nilai yang tercatat di ujung pipa lebih besar (misalnya $75 \mathrm{~cm}$ ) daripada nilai di pangkal pipa (misalnya $50 \mathrm{~cm}$ ), maka hal ini berarti bahwa lokasi di ujung pipa adalah $25 \mathrm{~cm}$ lebih rendah dari lokasi di bagian pangkal pipa. Begitu pula sebaliknya, bila nilai tercatat di ujung pipa lebih kecil (misalnya $25 \mathrm{~cm}$ ) daripada nilai di bagian pangkal pipa (misalnya $50 \mathrm{~cm}$ ), maka hal ini berarti bahwa lokasi di ujung pipa adalah $25 \mathrm{~cm}$ lebih tinggi dibandingkan dengan lokasi di pangkal pipa. Selisih nilai hasil pengukuran adalah besaran perbedaan ketinggian tempat di antara dua lokasi yang diukur (Gambar 4.5).

Untuk pengukuran titik selanjutnya dalam jalur, surveyor \#1 berpindahkelokasisurveyor \#2, sementara surveyor \#2 bergerak menuju titik pengukuran selanjutnya yang berjarak 25 m. Pada kondisi tersebut, surveyor \#2 akan mencatat ketinggian muka air di ujung pipa saat tinggi muka air di lokasi surveyor \#1 sudah mencapai ketinggian yang dicatat sebelumnya oleh surveyor \#2 (Gambar 4.6). 


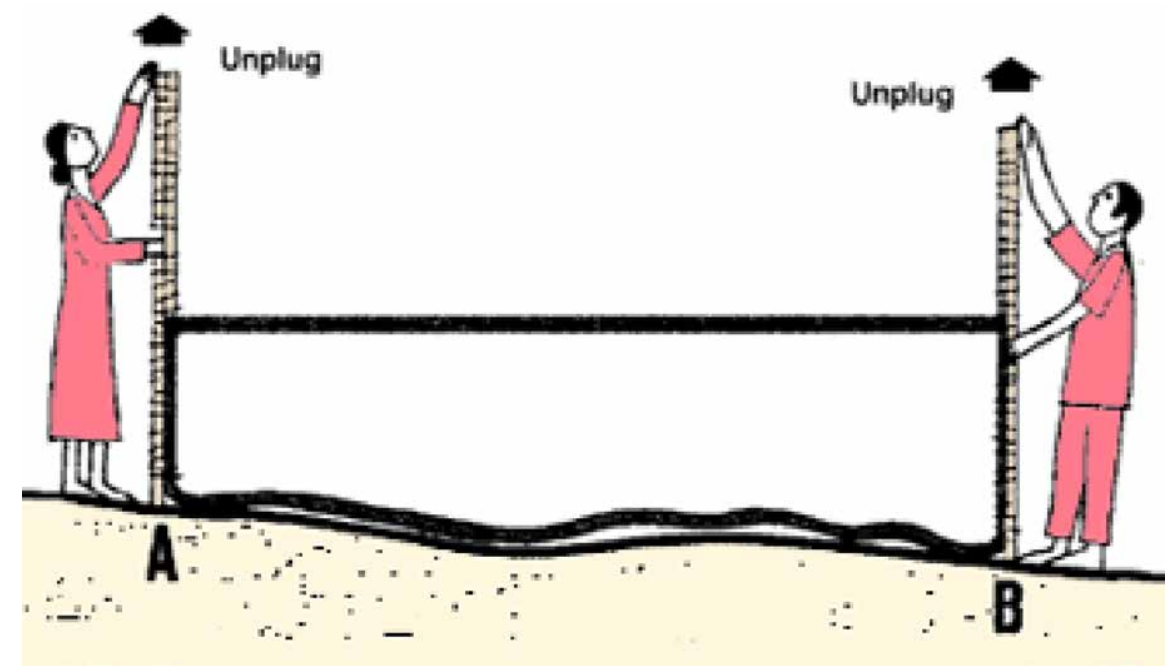

Gambar 4.5 Pengukuran perbedaan ketinggian antara dua lokasi yang berjarak $25 \mathrm{~m}$ oleh dua orang surveyor. Beda ketinggian antara titik A dan B merupakan selisih hasil pengukuran tinggi muka air di kedua titik tersebut.

Sumber gambar: www.fao.org

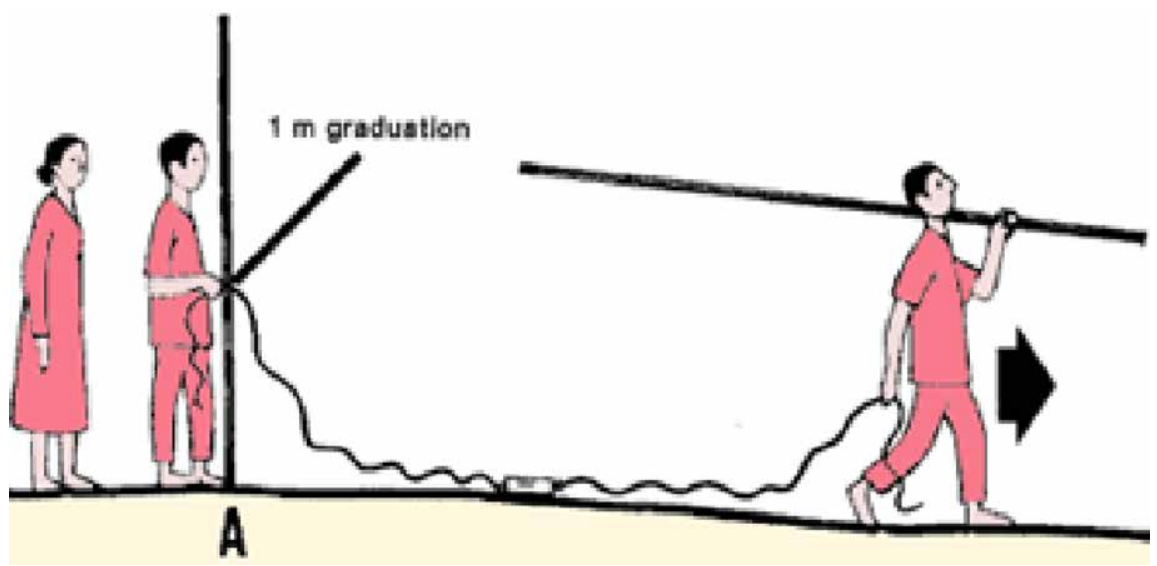

Gambar 4.6 Surveyor \#1 telah mencapai titik pengukuran surveyor \#2, dan surveyor \#2 bergerak menuju lokasi pengukuran berikutnya.

Sumber gambar: www.fao.org 
Waktu yang dibutuhkan untuk kegiatan ini sangat ditentukan oleh kondisi tutupan lahan dan keterampilan surveyor. Pengukuran pada lahan tertutup semak lebat akan membutuhkan waktu yang lebih lama untuk membersihkan jalur pengukurannya. Dua orang surveyor pengukuran topografi perlu dibantu oleh satu orang lain yang bertugas untuk melakukan pembersihan jalur dari semak belukar yang menghalangi dengan menggunakan parang/pisau panjang. Pada kegiatan ini, sekitar 40 titik pengukuran topografi dapat diselesaikan dalam waktu empat jam kerja (Gambar 4.7 dan Gambar 4.8).

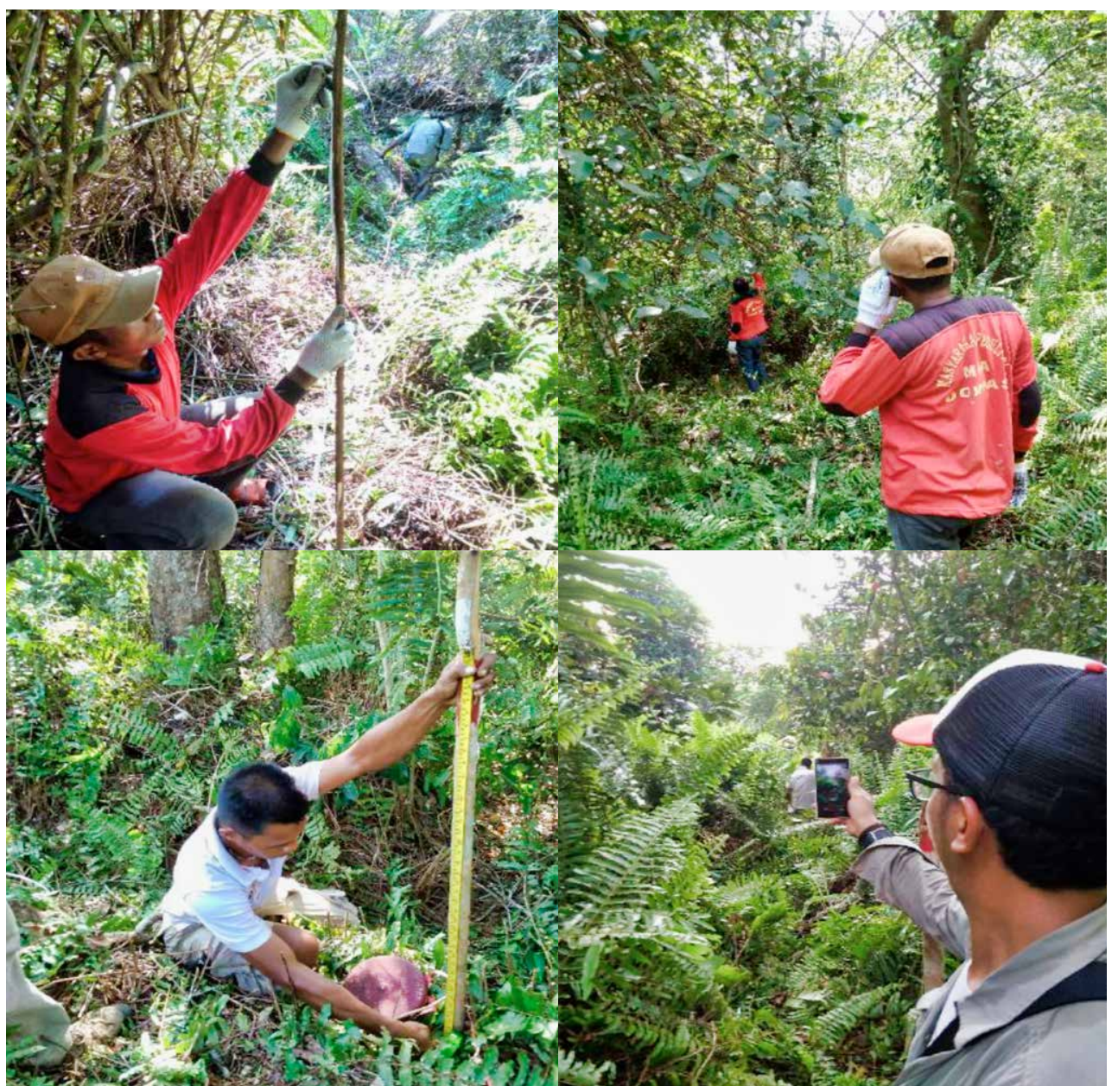

\section{Gambar 4.7 Pengukuran perbedaan ketinggian tempat oleh anggota MPA}

\section{Desa Dompas.}




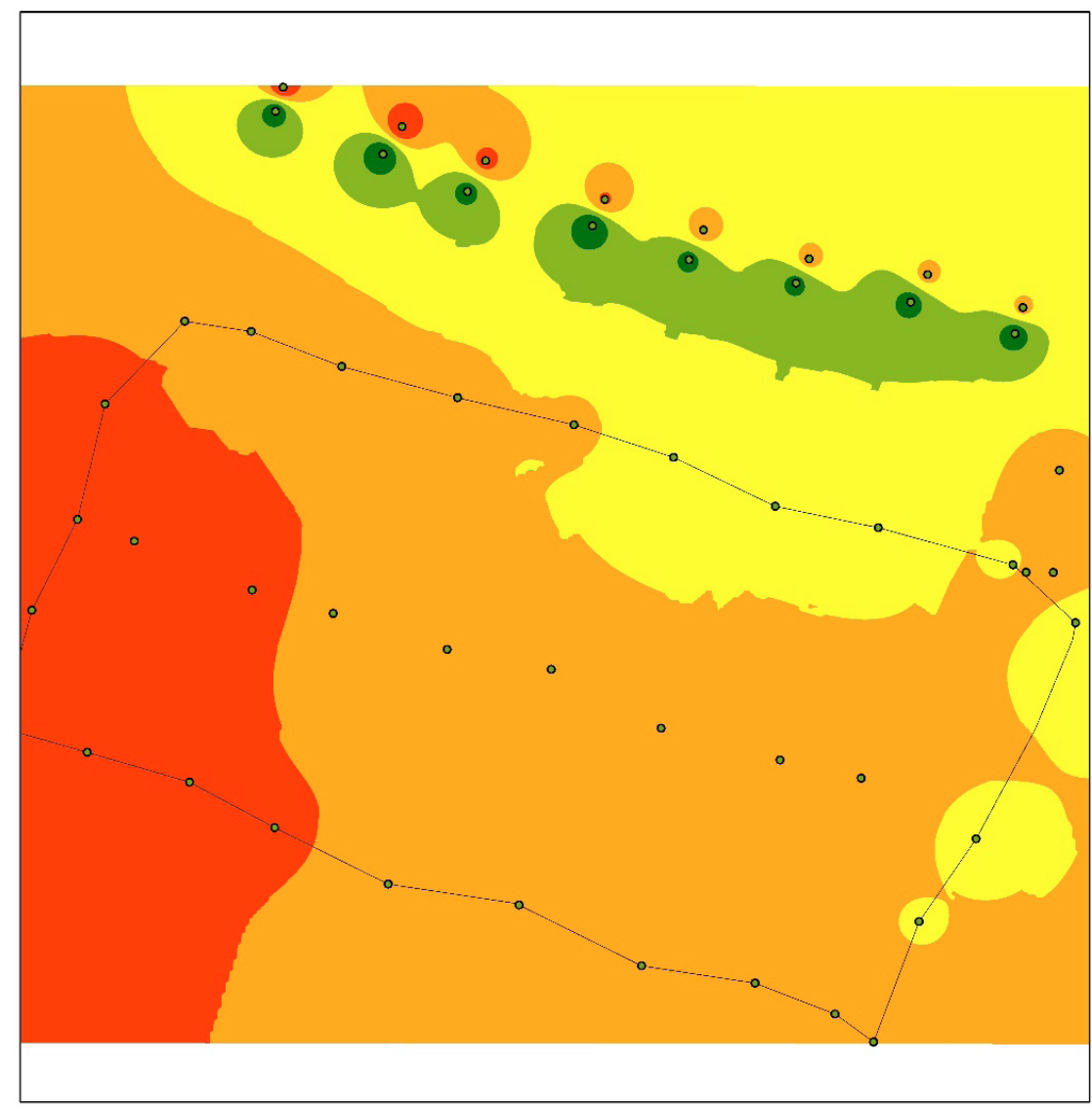

Model Elevasi Arena Aksi 1

Dompas, Tg. Batu,

Bengkalis, Riau
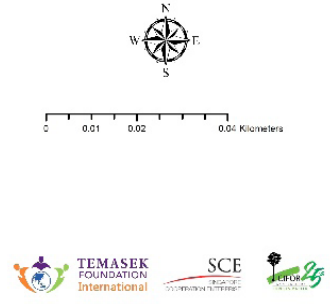

Legenda

- Titik ukur ketinggian Batas arena aksi

Elevasi ( $m$ asl)

$5.06-5.54$

$5.54-6.02$ $6.02-6.50$ $6.50-6.98$

$6.98-7.46$

Datum: WGS 1984

Coordinate system: UTM Zone 48

Source:

Survey data (CIFOR 2018)

DEMNAS (BIG 2018)

Google Earth imagery 2018

Gambar 4.8 Model ketinggian digital berdasarkan hasil pengukuran lapangan terhadap titik-titik pengamatan di dalam Arena Aksi \#1. 
Selain pengukuran topografi, dilakukan juga pengukuran kualitas gambut secara sederhana dengan menggunakan pendekatan kualitatif seperti dijelaskan dalam Agus dkk. (2011). Pengukuran dilakukan dengan mengambil sekitar setengah genggam bahan gambut dari permukaan tanah, kemudian diremas dalam kondisi basah. Selanjutnya dengan mengamati jumlah gambut yang tersisa setelah proses peremasan, maka dapat diperkirakan jumlah sisanya dibanding jumlah awalnya. Kualitas gambut diklasifikasikan berdasarkan jumlah sisa gambut tersebut, yaitu: 1) $>75 \%$ menunjukkan gambut muda/ "fibrik"; 2) 15-75\% mengindikasikan kondisi gambut setengah lapuk/"hemik"; dan 3) <15\% menunjukkan kualitas gambut yang terlapuk/"saprik" (Gambar 4.9). Kualitas "saprik" dapat menjadi indikasi bahwa bahan gambut sudah cukup mengalami pelapukan melalui proses oksidasi, sedangkan kualitas "fibrik" menunjukkan gambut yang masih mengandung bahan organik segar dan serat perakaran.

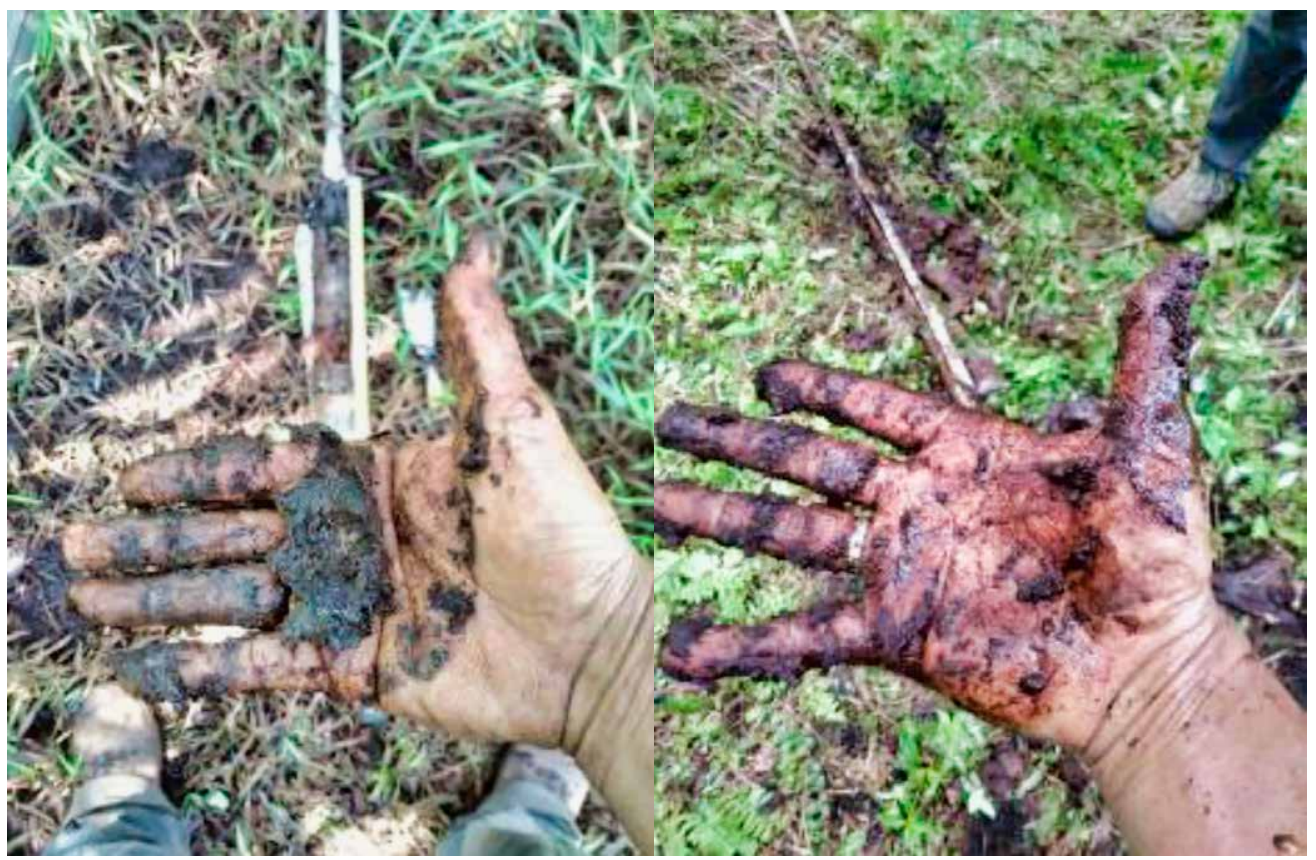
Gambar 4.9 Pengukuran kualitatif tingkat pelapukan gambut: hemik atau pelapukan gambut sedang (kiri) dan saprik atau pelapukan gambut lanjut (kanan). 
Beberapa anggota masyarakat yang terpilih juga dilatih untuk dapat melakukan pengukuran kedalaman gambut dan pengambilan contoh gambut menggunakan bor tipe eijkelkamp (Gambar 4.10). Jalur pengambilan contoh gambut adalah sepanjang $150 \mathrm{~m}$, yang terdiri dari 6 lokasi pengambilan yang masing-masing berjarak $30 \mathrm{~m}$ (Kauffman dkk. 2016). Tiga contoh gambut dikumpulkan dari tiap lokasi pengeboran, masing-masing diambil secara hati-hati dari kedalaman 40-45 cm, 70-75 cm, dan 195$200 \mathrm{~cm}$ dari permukaan tanah (Chimner dkk. 2014). Tiap contoh gambut tersebut disimpan dalam plastik contoh dengan label berkode unik, dan segera dikirimkan ke laboratorium tanah untuk dianalisis kandungan karbonnya. Selain contoh gambut tersebut, sekitar $1 \mathrm{~kg}$ tanah gambut dari permukaan tanah juga dikumpulkan dari tiap lokasi pengeboran, yang disimpan dalam plastik berkode unik, untuk analisis karakteristik kimia di laboratorium tanah. Kegiatan-kegiatan tersebut dilakukan di tiap arena aksi dalam riset aksi partisipatif CIFOR di Desa Dompas.

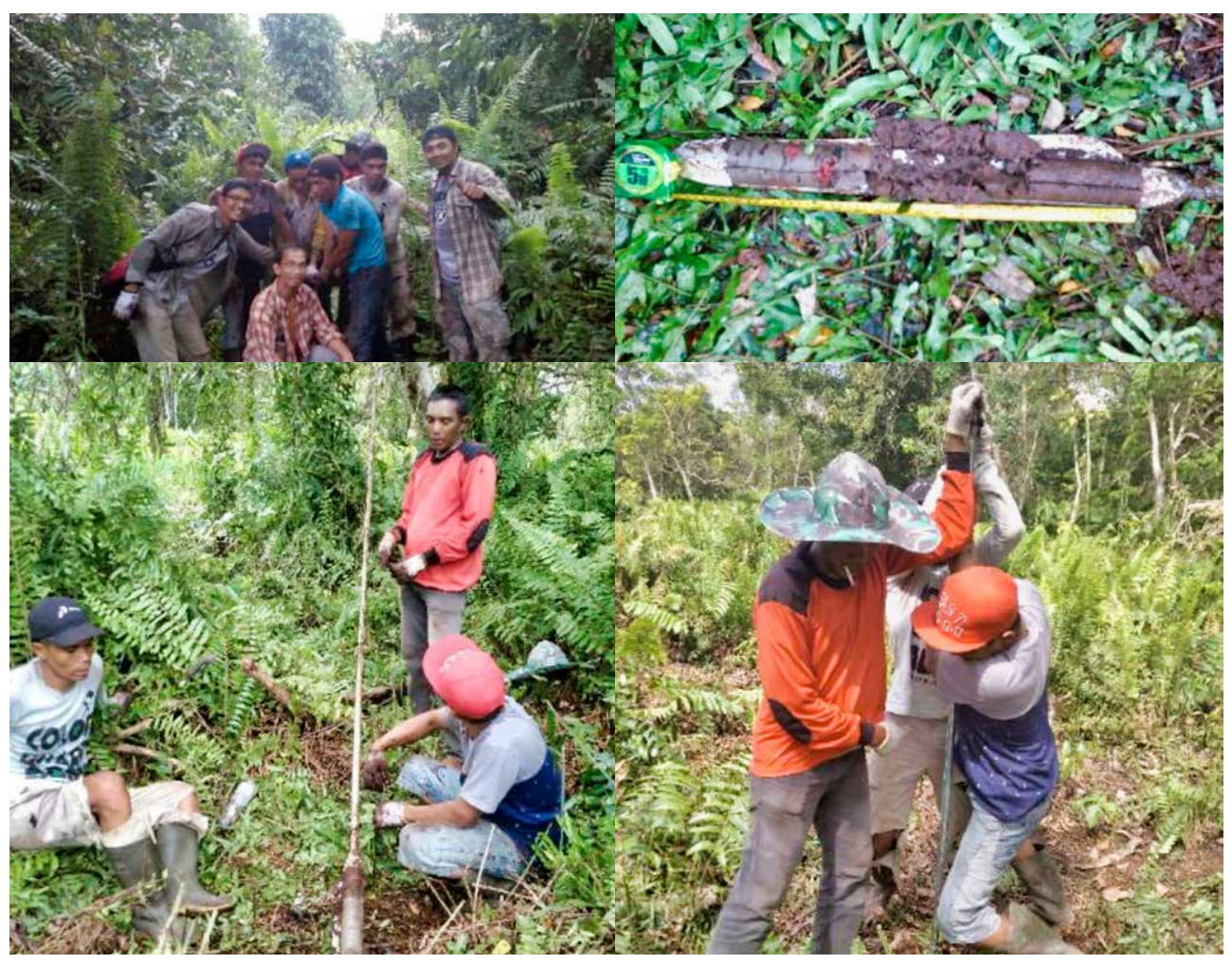

Gambar 4.10 Pengukuran kedalaman dan pengambilan contoh gambut. 
Kegiatan pemetaan kedalaman gambut juga dilakukan terhadap seluruh wilayah desa, untuk memperoleh peta gambut yang lebih detail dan akurat yang dapat digunakan untuk keperluan kegiatan penelitian di tingkat desa. Pemetaan tersebut dilakukan dengan pendekatan semisistematis dan memanfaatkan peta-peta dasar yang ada sebagai peta kerja. Peta kerja dibuat dengan mengekstrak informasi berupa batas wilayah gambut, kedalaman gambut, batas desa, sungai dan jalan, dan menambahkan titik-titik lokasi rencana pengukuran kedalaman gambut ke dalamnya. Titik-titik lokasi pengukuran diatur untuk dapat merepresentasikan variasi kedalaman seperti yang digambarkan dalam peta gambut Ritung dkk. (2011), dan menentukan batas wilayah gambut dan nongambut (Gambar 4.11).

Pada wilayah batas gambut dan nongambut, pengamatan yang lebih rapat perlu dilakukan untuk dapat mengidentifikasi lokasi-lokasi yang menjadi batasnya. Pada wilayah tersebut, lokasi pengamatan dibuat pada jarak $250 \mathrm{~m}$ atau lebih dekat sesuai dengan hasil pengamatan di lapangan. Pada wilayah lainnya (kedalaman gambut $1-6 \mathrm{~m}$ ), pengamatan dilakukan dengan jarak antar titik pengamatan sejauh $500 \mathrm{~m}$. Pengamatan acak dilakukan pada wilayah dengan kedalaman gambut $>6 \mathrm{~m}$.

Pada tiap titik pengamatan dilakukan pengukuran kedalaman gambut dengan menggunakan bor yang dapat diperpanjang hingga mencapai $20 \mathrm{~m}$. Batas gambut dan mineral harus diperiksa dengan pengambilan contoh gambut pada bagian batas dan memotretnya.

Data kedalaman gambut, posisi geografi dan foto dari semua lokasi pengukuran disimpan dalam aplikasi ArcGis Collector, untuk kemudian diunduh dan disimpan ke dalam komputer melalui perangkat lunak ArcGis 10.4.1. Model kedalaman gambut untuk sebagian besar wilayah Desa Dompas dapat dibangun berdasarkan data pengamatan yang sudah disimpan dalam komputer dengan menggunakan metode Kriging (Oliver $^{\circ}$ 1990). Hasil tersebut memberi informasi yang bermanfaat dalam proses refleksi mengenai kondisi gambut di wilayah penelitian dan implikasinya terhadap kegiatan pengelolaan lahan.

Hasil pengukuran menunjukkan bahwa seluruh arena aksi berada pada wilayah dengan gambut yang sangat dalam, yaitu lebih dari 4 m (Gambar 4.11). Hal ini berarti bahwa seluruh kegiatan dalam penelitian RAP ini perlu difokuskan dan direfleksikan pada kegiatan-kegiatan yang mengupayakan rehabilitasi dan restorasi ekosistem gambut. Patut dicatat bahwa peta model kedalaman gambut yang dihasilkan ternyata kontras dengan informasi yang diperoleh dari peta gambut Ritung dkk. (2011), yang menunjukkan bahwa semua arena aksi berada pada wilayah gambut tipis ( $<1 \mathrm{~m}$ ). Hal ini kemungkinan disebabkan oleh skala peta gambut yang cukup kasar (skala peta tinjau), sehingga terdapat perbedaan klasifikasi kedalaman gambut tersebut. Mengingat hal

4 https://desktop.arcgis.com/en/arcmap/10.3/tools/3d-analyst-toolbox/how-kriging-works.htm\#ESRI_SECTION1_ F2C5B52BEBED4A01BB90828985284ACB 


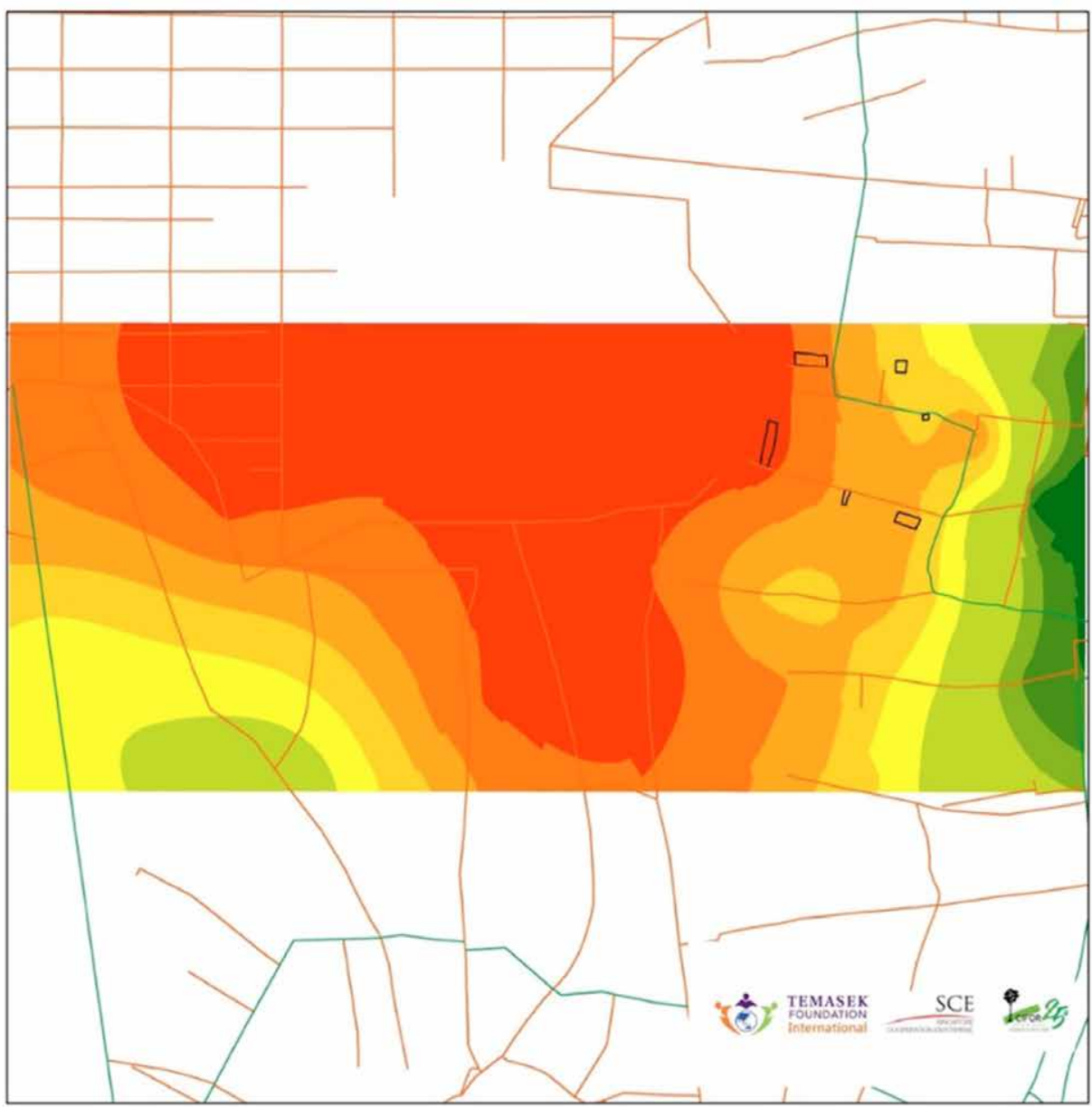

Peat Depth and Action Arena,

Dompas, Tg. Batu,

Bengkalis, Riau

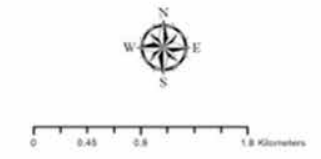

Legend

Main Road

- Other Road

$\square$ Arena boundary

Peat depth $(\mathrm{m})$

0

$0-0.5$

$0.5-1$

ए $1-3$

$\square-4$

प-5

$\square-6$

$6-7$

$7-8$

Datum: WGS 1984

Coordinate system: UTM Zone 48

Source:

Survey data (CIFOR 2018)

DEMNAS (BIG 2018)

Google Earth imagery 2018

Gambar 4.11 Model kedalaman gambut dan arena-arena aksi di Desa Dompas. 
tersebut, maka untuk kegiatan-kegiatan penggunaan lahan gambut pada tingkat desa, perlu dilakukan pemeriksaan kedalaman gambut dengan skala pengamatan semidetail (1:50.000) atau yang lebih detail lagi.

Hasil kegiatan-kegiatan pada fase refleksi ini, termasuk dengan diketahuinya kedalaman gambut dan kondisi kanal drainase di wilayah tersebut, menguatkan argumen tentang perlunya dilakukan kegiatan restorasi di wilayah gambut terdegradasi Desa Dompas. Hal ini juga menunjukkan pentingnya kegiatan observasi lapangan dan informasi yang akurat mengenai kondisi biofisik wilayah (sebaran kanal, sungai, jalan dan tutupan lahan) dalam fase refleksi, agar dapat dihasilkan perencanaan yang baik pada tahap selanjutnya, yaitu fase perencanaan dan fase aksi.

\subsubsection{Fase perencanaan}

Pada fase perencanaan, para pihak yang berpartisipasi sebaiknya sudah memahami dengan baik mengenai kondisi semua arena aksi sebagai obyek penelitian. Rencana yang dibuat perlu didasarkan pada bukti-bukti yang didapatkan pada fase refleksi. Diperlukan perencanaan yang baik dan solusi yang tepat untuk pembangunan sekat kanal, sebagai cara yang telah disepakati untuk mengatasi masalah kering dan tingginya risiko kebakaran gambut. Sekat kanal harus mampu membasahi kembali wilayah gambut yang kering, yaitu dengan peningkatan tinggi muka air tanah yang akan membasahi gambut, sehingga menurunkan ancaman kebakaran lahan.

Semua informasi yang relevan dengan karakteristik gambut perlu dikaji, misalnya terkait kualitas gambut (fibrik, hemik dan saprik). Informasi tersebut menunjukkan tentang bagaimana kondisi gambut yang ada terkait dengan kemampuannya melewatkan air (konduktivitas hidrolik) dan kandungan nutrisi bagi tanaman.

Informasi topografi di tiap arena aksi akan memberikan petunjuk tentang arah pergerakan air di lokasi tersebut. Tempat yang lebih rendah merupakan daerah dimana air akan terkonsentrasi, dan tempat yang lebih tinggi menunjukkan daerah yang menjadi sumber aliran air. Titik referensi ketinggian tempat dapat diperoleh dari citra Demnas (Digital elevation model nasional) dari Badan Informasi Geospasial (BIG).

Saat ini, foto udara yang dapat diambil menggunakan kamera yang dipasang pada pesawat tanpa awak atau Unmanned Aerial Vehicle (UAV) dapat menyediakan informasi tentang jaringan kanal, tutupan lahan, kondisi vegetasi dan lain-lain (Gambar 4.12). Jaringan kanal merupakan informasi yang sangat penting untuk merencanakan posisi sekat kanal sebagai bagian dari keseluruhan sistem tata air di wilayah penelitian. Kondisi tutupan lahan dan vegetasi menjadi informasi dasar penting dalam mengkaji dampak restorasi gambut. 

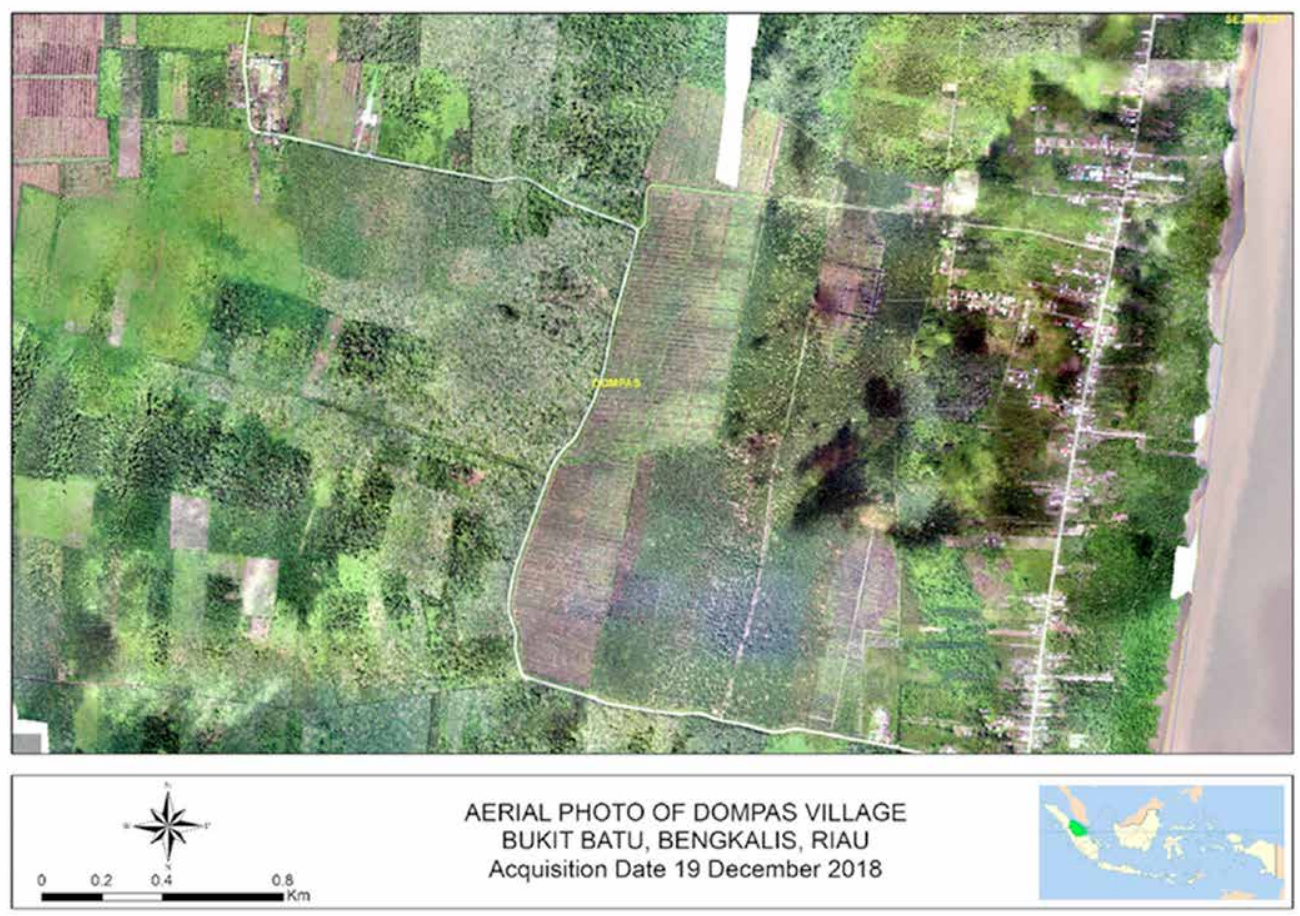

\section{Gambar 4.12 Foto udara arena-arena aksi di sebelah barat Desa Dompas dan garis pantai.}

Untuk memahami status kondisi hidrologi wilayah penelitian maka perlu dilakukan kajian hidrologi yang menganalisis neraca air. Analisis tersebut akan menginformasikan mengenai kondisi historis dari terjadinya kelebihan atau defisit air di wilayah studi. Fluktuasi tinggi muka air tanah dapat diprediksi apabila terdapat data tinggi muka air tanah dan curah hujan selama enam bulan (Gambar 4.13). Informasi tersebut sangat penting bagi kebijakan pengelolaan air di wilayah studi. 


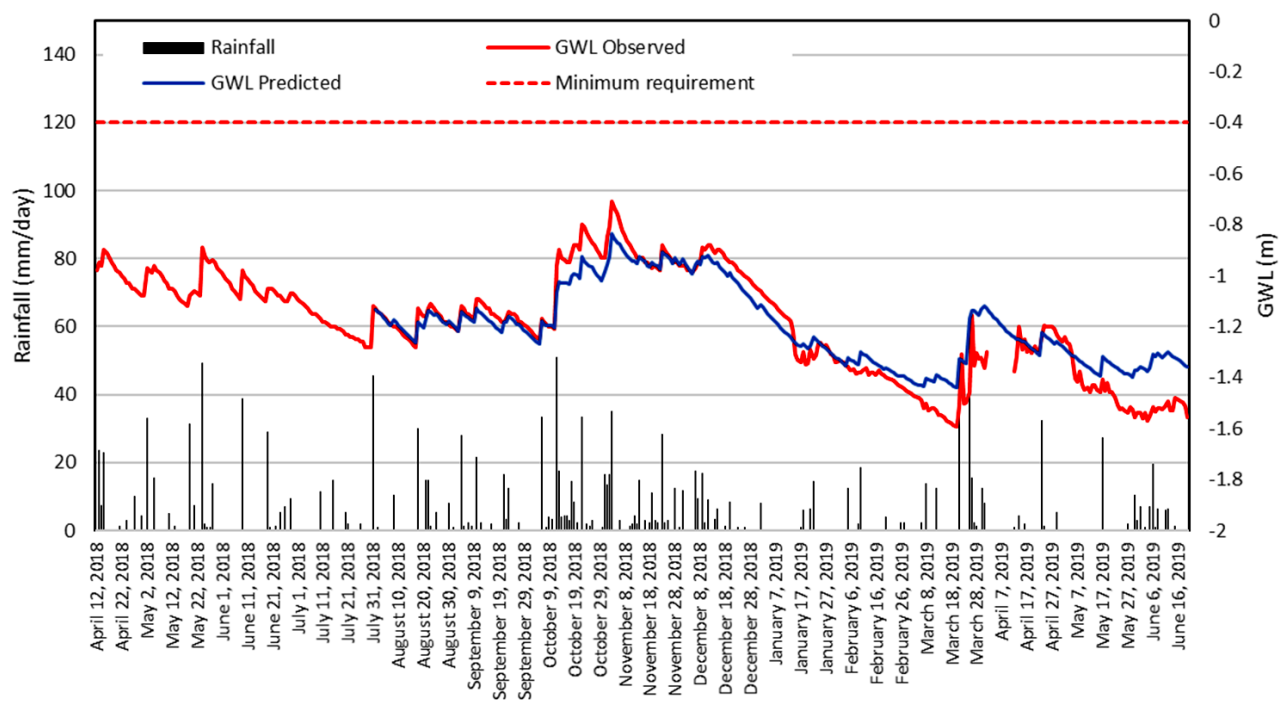

\section{Gambar 4.13 Tinggi muka air $(\mathrm{m})$ hasil pengukuran dan prediksi model, serta data pengamatan curah hujan harian $(\mathrm{mm})$ dari satu stasiun pengamatan milik BRG di lokasi penelitian.}

\subsubsection{Fase aksi}

Desain sekat kanal harus didiskusikan dengan baik dan matang bersama orangorang yang terpilih untuk ikut serta dalam kegiatan pembangunan. Sangat penting untuk dapat menemukan masyarakat yang mengerti tentang proses kerja dan kualitas konstruksi sekat kanal. Fasilitator desa berperan penting dalam menemukan anggota masyarakat yang memiliki kemampuan tersebut. Selain kerangka kerja partisipatif, perlu dipertimbangkan pula tentang bagaimana cara untuk menjamin kualitas dan fungsi dari infrastruktur pembasahan gambut. Sekat kanal harus tahan lama $>5$ tahun) dan berfungsi baik dalam meningkatkan tinggi muka air tanah. Untuk menjamin bahwa sekat kanal yang dibangun sesuai dengan syarat dan peraturan yang berlaku, desain sekat kanal sebaiknya juga dibandingkan dengan dokumen pembangunan sekat kanal dari BRG (BRG 2016; Gambar 4.14), KLHK, ${ }^{5}$ dan publikasi lain yang relevan (Ritzema dkk. 2014; Gambar 4.15). Badan Restorasi Gambut (BRG) telah menerbitkan petunjuk pembuatan sekat kanal di lingkungan gambut (Dohong dkk. 2017). Bab ini khususnya ditujukan untuk memastikan bahwa langkah-langkah yang diperlukan dapat dipenuhi dan diadaptasikan dengan kondisi dan situasi desa, baik secara sosial maupun secara biofisik. 

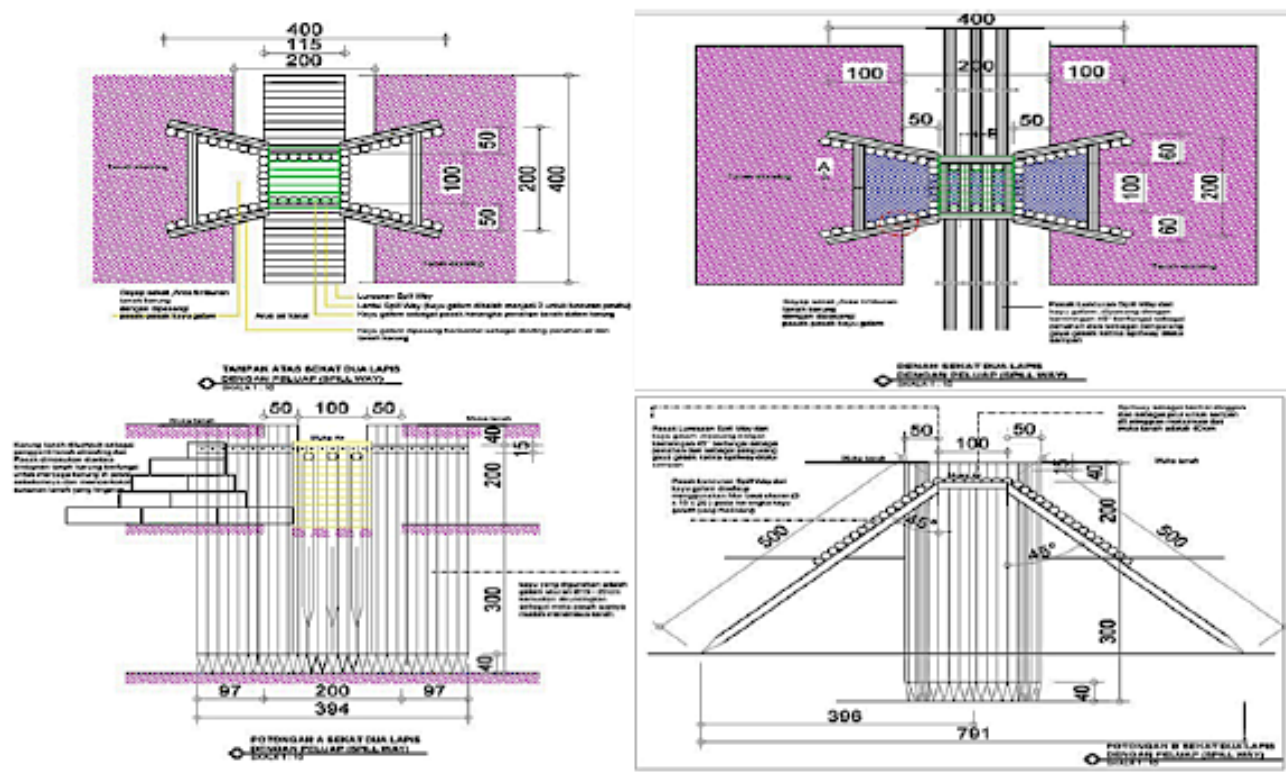

\section{Gambar 4.14 Desain sekat kanal yang disarankan oleh Dohong dkk. (2017) untuk tipe sekat berkualitas tinggi (permanen).}

Diskusi mengenai jadwal kerja, spesifikasi desain sekat kanal, material yang diperlukan, metode, dan target kerja dilakukan sebelum pelaksanaan pembangunan. Sekelompok masyarakat (9 orang) termasuk sebagian anggota MPA Desa Dompas, harus menyepakati syarat dan ketentuan pekerjaan pembangunan sekat kanal. Penting untuk dijelaskan dan dipahami oleh pelaksana kerja bahwa hasil kegiatan harus memenuhi jadwal dan kualitas yang diharapkan. Tugas dan jadwal harian didiskusikan dan dibuat untuk disepakati bersama-sama dengan semua anggota kelompok kerja.

Penempatan lokasi sekat kanal harus mempertimbangkan kondisi topografi di sekitarnya, dan dibuat pada tempat paling rendah dari arena aksi. Hal ini dimaksudkan agar air yang terkumpul akan dapat membasahi wilayah dalam arena aksi.

Jenis konstruksi sekat kanal akan dibuat berdasarkan ketersediaan material dan kapasitas tenaga kerja setempat. Kualitas konstruksi perlu menyesuaikan dengan lebar kanal dan potensi jumlah air yang akan terkumpul selama periode transisi antara musim hujan dan musim kemarau. Semakin lebar kanal dan semakin banyak jumlah air yang akan terkumpul, maka jenis konstruksi sekat kanal yang dibuat harus lebih kuat. 


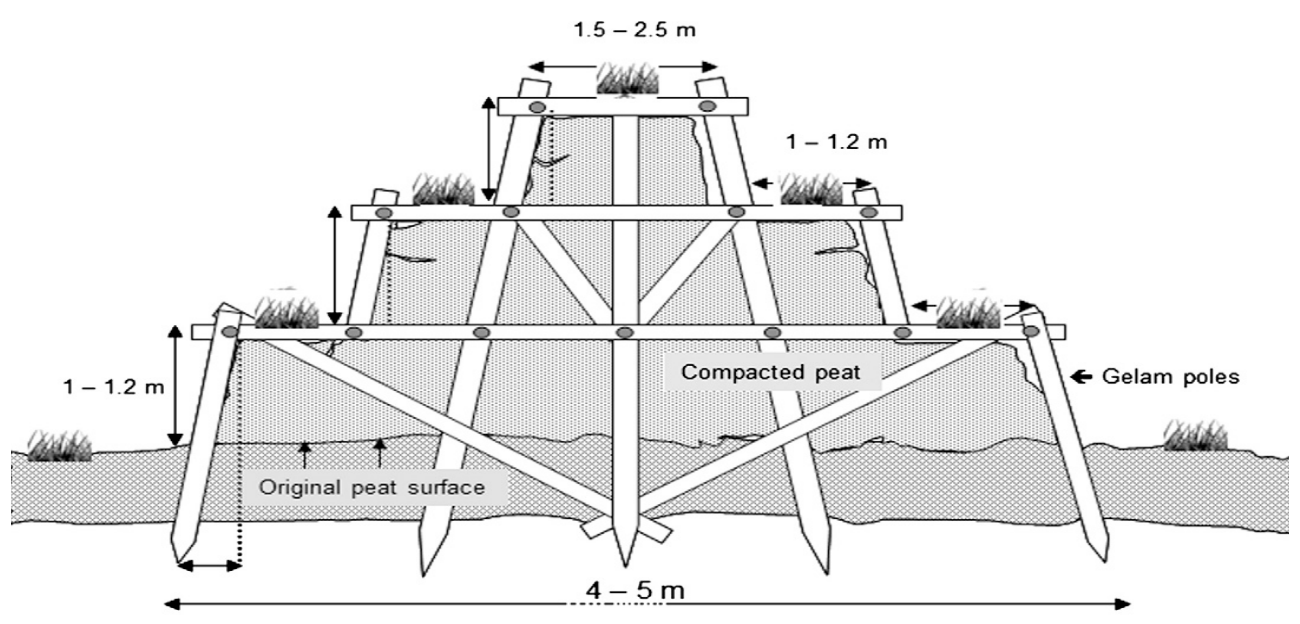

Gambar 4.15 Desain sekat kanal (Ritzema dkk. 2014) berkualitas tinggi (permanen), dengan bahan yang tersedia di wilayah desa seperti kayu bulat dan bahan gambut.

Untuk menjamin kualitas sekat kenal, pembangunan sekat kanal harus diawasi oleh seorang ahli hidrologi atau peneliti. Prosedur standar pelaksanaan pembangunan sekat kanal harus dipenuhi dan dilaksanakan secara konsisten dan hati-hati.

Prosedur standar pelaksanaan pembuatan sekat kanal mencakup hal-hal di bawah ini:

- Pembangunan sekat kanal sebaiknya dilakukan pada musim kemarau, yaitu saat tinggi muka air dalam kanal cukup rendah. Pada musim hujan akan sangat sulit dan berisiko untuk membangun sekat kanal yang baik dan kuat, terutama dalam membendung aliran air dan mengalihkan alirannya selama proses pembangunan.

- Bahan yang dibutuhkan untuk pembangunan sekat kanal sebaiknya dipilih dan dibeli sesuai dengan ketersediaan di lokasi setempat. Jangan menggunakan bahan yang sulit untuk didapatkan, yang berpotensi menghambat pekerjaan. Semua bahan tersebut harus dibeli dan dikumpulkan secara periodik di lokasi pekerjaan sesuai tahap kemajuan pembangunannya. Bahan-bahan tersebut termasuk: pipa PVC, besi beton $12 \mathrm{~mm}$, semen, pasir, kerikil, tanah mineral, papan multiplex, batang kayu (gelam/Melaleuca sp.), jaring besi berdiameter $6 \mathrm{~mm}$, terpal tebal dan anti air, karung goni, dan paku. 
- Persiapkan delapan buah pasak sepanjang 6 m, dari pipa PVC berukuran diameter $10 \mathrm{~cm}$ yang ujungnya diruncingkan dan diisi dengan beton. Tancapkan pasak pada posisi yang akan menjadi tiang utama sekat kanal. Setelah tertancap hingga lapisan mineral, pasak tersebut kemudian diisi penuh dengan campuran beton cair (Gambar 4.16).

- Pada kanal selebar $6 \mathrm{~m}$, bagian sayap dari sekat kanal harus dibuat paling tidak $1 \mathrm{~m}$ ke empat arah sisi kanal dengan lebar galian sekitar $30 \mathrm{~cm}$. Pekerjaan dimulai dengan menggali bagian sisi tersebut sedalam kanal. Untuk kanal dengan lebar 1,5 m, hanya dibutuhkan pembuatan sayap ke dua arah sisi sekat kanal, kiri dan kanan, pada sekat bertipe satu lapisan dinding (Gambar 4.17).

- Siapkan batang kayu bulat yang akan dijadikan bagian dalam (tulang) dari dinding sekat kanal. Tiang-tiang kayu tersebut berukuran diameter sekitar $10 \mathrm{~cm}$, yang ujungnya harus diruncingkan dengan chainsaw. Panjang batang kayu yang dibutuhkan adalah sekitar $7 \mathrm{~m}$ yang ditancapkan ke dalam kanal hingga menembus lapisan tanah mineral. Setelah tertancap, dinding kayu tersebut kemudian diikat dengan memakukan papan panjang selebar $5 \mathrm{~cm}$ di bagian atas kayu. Pada sekat dengan lebar kanal 6 m, akan dibutuhkan sekitar 90 batang kayu bulat, sedangkan pada kanal dengan lebar $2 \mathrm{~m}$, hanya dibutuhkan sekitar 30 batang kayu bulat.
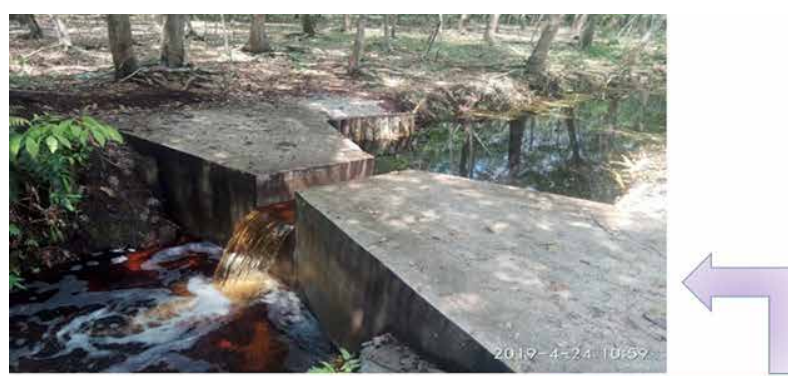

\section{Desain sekat kanal}

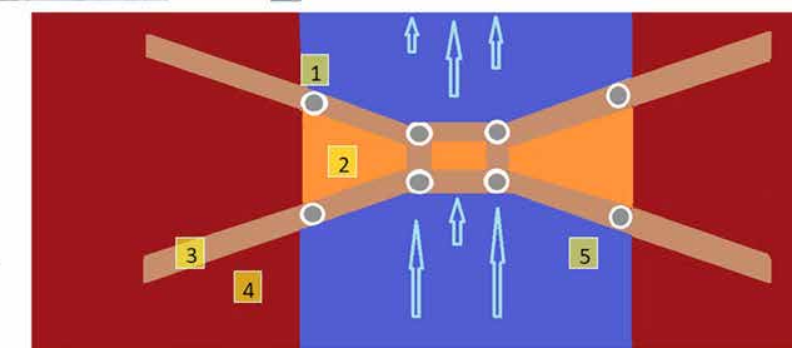

1 - Tiang pasak utama beton $10 \mathrm{~cm}$

2 - Tanah mineral dalam karung/dilapis beton

3 - Tiang kayu (gelam) di dalam dinding beton.

4 - Tanah gambut

5 - Aliran air kanal (lebar $6 \mathrm{~m}$ )

\section{Gambar 4.16 Desain sekat kanal berkualitas tinggi (permanen) yang disepakati bersama anggota masyarakat.}




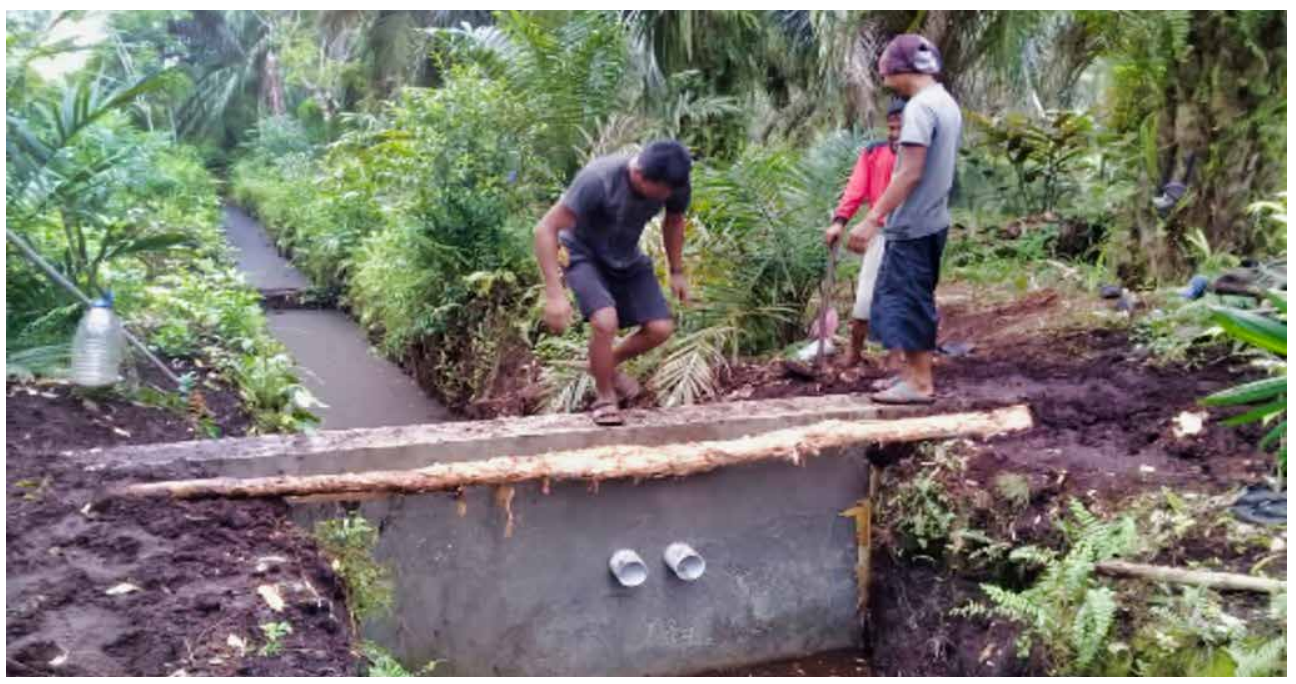

\section{Gambar 4.17 Sekat kanal dengan satu lapisan dinding beton yang disepakati bersama anggota masyarakat dengan tipe yang berkualitas tinggi (permanen).}

- Pada bagian tengah sekat kanal, jalan keluar air/pintu air disiapkan dengan desain lebar sekitar $1 \mathrm{~m}$ dan dengan kedalaman $40 \mathrm{~cm}$ dari permukaan sekat.

- Komposisi bahan dinding sekat kanal harus terdiri dari kombinasi bahan kayu bulat, jaring besi, dan beton, yang dibentuk dengan kayu lapis yang sudah diperkuat dengan bingkai dari kayu. Bingkai kayu lapis tersebut dapat dilepas setelah beton dinding sekat kering sempurna.

- Bagian dalam di antara dua dinding sekat pada kanal selebar $6 \mathrm{~m}$ diisi dengan karung-karung berisi tanah mineral, yang bagian luarnya dilapisi dengan terpal tebal anti air. Bagian dasar sekat kanal harus dipadatkan dengan cara diinjak-injak, sebelum diisi dengan karung tanah mineral. Setelah diisi dengan karung tanah mineral, bagian tersebut diratakan dengan menambahkan pasir dan dipadatkan. Jika semua proses ini telah dilakukan, maka bagian atas dari sekat kanal akan siap untuk diberikan jaring besi dan dibeton.

Desain alternatif untuk pembangunan sekat kanal juga telah dibuat dan ditujukan untuk mengurangi tenaga jatuhan air yang dapat menggerus dasar kanal. Desain tersebut menggunakan jenis spillway atau buangan air yang disebut "morning glory" dengan bahan pipa PVC, berdiameter 4 inci (Gambar 4.18). 

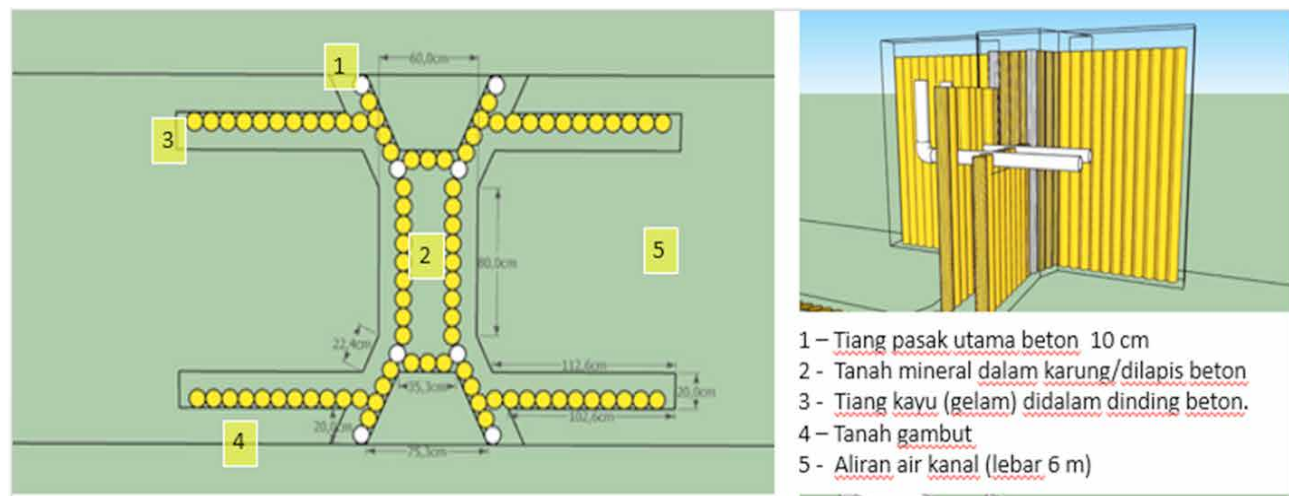

1 - Tiang pasak utama beton $10 \mathrm{~cm}$

2 - Tanah mineral dalam karung/dilapis beton

3 - Tiang kayu (gelam) didalam dinding beton.

4- Tanah gambut

5 - Aliran air kanal (lebar $6 \mathrm{~m})$
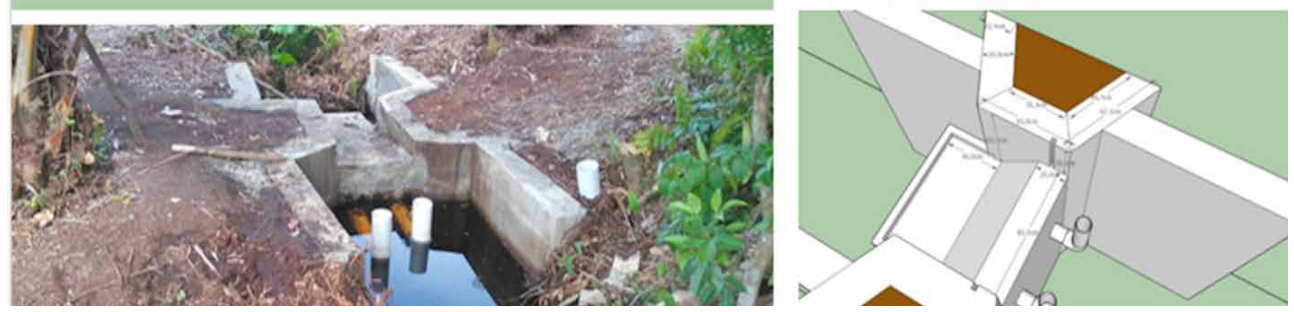

\section{Gambar 4.18 Desain alternatif sekat kanal dengan spillway 'morning glory'.}

Penggunaan desain dengan spil/way morning glory, memungkinkan pengaturan tinggi muka air yang ada di kanal sesuai kebutuhan. Prosedur pekerjaan yang dibutuhkan dalam membangun sekat kanal dengan spillway tersebut sama seperti yang dilakukan untuk pembangunan sekat pada kanal $6 \mathrm{~m}$. Perbedaannya adalah bahwa pipa PVC untuk spillway harus dipasang tepat setelah memasang pasak beton tiang utama sekat. Sekat dengan jenis 'morning glory' telah dibangun pada arena aksi 2, 3 dan 5, untuk melengkapi sekat kanal lain yang sudah dibangun sebelumnya pada arena aksi 1,4 and 6.

Pembangunan sekat kanal dengan tipe dua lapisan tembok dan berkualitas tinggi membutuhkan biaya sekitar 25,5 juta rupiah, pada lebar kanal sekitar 6 m. Pembangunan sekat kanal dengan tipe satu lapisan tembok hanya memerlukan biaya sekitar 3 juta rupiah, pada lebar kanal sekitar 1,5 m. Biaya-biaya tersebut diperlukan untuk membeli kebutuhan bahan, sewa alat, dan upah pekerja, dan menambahkan informasi pada keperluan biaya rencana strategi restorasi gambut nasional (BRG 2016). 


\subsubsection{Fase pemantauan}

Fase pemantauan sangat penting untuk mengetahui dampak pembangunan kanal dalam pencapaian tujuannya, yaitu untuk membasahi kembali lahan gambut yang mengering dan rawan terbakar pada musim kemarau. Untuk melakukan hal tersebut, maka perlu dilakukan identifikasi terhadap variabel-variabel yang merepresentasikan kondisi gambut yang terbasahi kembali, untuk kemudian diukur secara periodik. Beberapa variabel penting diantaranya adalah tinggi muka air tanah yang lebih dekat dengan permukaan tanah, kelembaban tanah gambut yang lebih tinggi, dan laju penurunan permukaan gambut yang lebih lambat, bila dibandingkan dengan kondisi di wilayah tanpa pembangunan sekat kanal. Pemilihan lokasi yang dapat digunakan sebagai kontrol pembanding (referensi) perlu dilakukan, sedapat mungkin pada lokasi yang berdekatan dan mirip kondisinya dengan wilayah yang telah diintervensi dengan keberadaan sekat kanal. Keberadaan lokasi referensi untuk setiap lokasi pembangunan sekat kanal memungkinkan peneliti untuk menguji dampak dari keberadaan sekat kanal tersebut.

Beberapa langkah yang penting dalam kegiatan pemantauan dampak sekat kanal antara lain:

- Mengidentifikasi lokasi referensi sebagai kontrol dari lokasi yang sudah dipengaruhi oleh pembangunan sekat kanal.

- Menentukan lokasi yang efektif untuk menjadi tempat pengukuran variabel dampak sekat kanal, misalnya tinggi muka air tanah, kelembaban tanah, dan laju penurunan muka permukaan gambut, perlu diidentifikasi dalam desain pemantauan. Ritzema dkk. (2014) melaporkan bahwa kanal dapat mempengaruhi tinggi muka air lahan gambut hingga jarak 1.000 m secara tegak lurus dari kanal. Namun pada kegiatan refleksi telah diketahui bahwa jarak antar kanal di beberapa arena aksi adalah kurang dari 400 m (Gambar 4.19). Dengan mempertimbangkan hal tersebut, maka kami memutuskan untuk melakukan pengukuran dampak hingga $100 \mathrm{~m}$ dari kanal, yang dipastikan merupakan wilayah yang dipengaruhi oleh kanal yang disekat (berada sebelum jarak lokasi yang tepat berada diantara dua kanal/200 m), dan tanpa dipengaruhi oleh kanal yang berada di wilayah sebelahnya. Hal ini dengan mempertimbangkan bahwa wilayah diantara dua kanal akan dipengaruhi tidak hanya oleh salah satu kanal, tetapi oleh kedua kanal. 


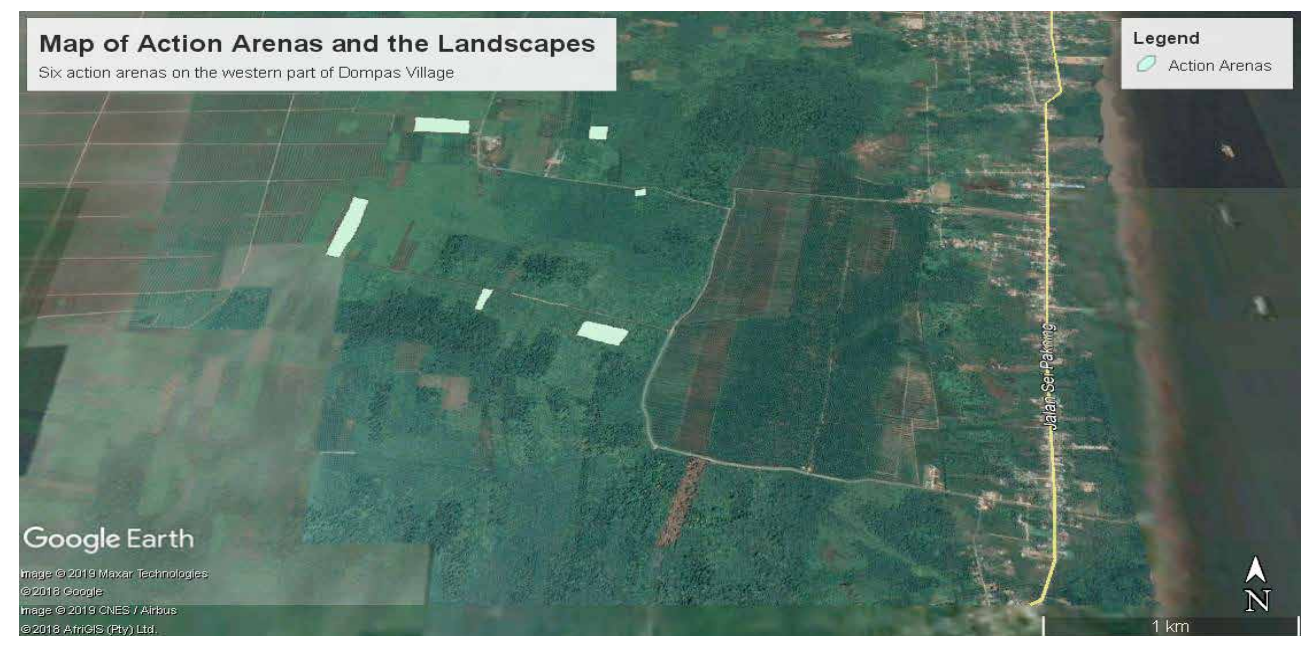

Gambar 4.19 Lokasi enam arena aksi (kotak berwarna hijau cerah) di sebelah barat wilayah Desa Dompas dan garis pantai. Garis putih adalah jalan yang diapit oleh dua kanal di sebelah kiri kanannya, dan mempercepat pengeringan air dari lahan gambut.

\subsubsection{Pengukuran tinggi muka air tanah (TMA)}

Untuk mengukur dampak sekat kanal, delapan sumur pantau tinggi muka air tanah gambut telah dibuat di sekitar arena aksi. Empat sumur pantau diposisikan di dalam lokasi arena aksi yang mewakili wilayah yang terkena dampak sekat kanal. Sumur pantau pertama dibuat pada lokasi yang berjarak sekitar $5 \mathrm{~m}$ di sebelah hulu lokasi sekat kanal. Tiga sumur pantau lainnya diposisikan untuk membentuk formasi bujur sangkar dengan sisi yang berjarak 100 m. Sumur pantau lainnya (4 dari 8 sumur) dibuat pada wilayah yang menjadi kontrol/referensi dari wilayah terdampak sekat kanal, tepat di seberang arena aksi atau di sekitarnya (Gambar 4.20, Gambar 4.21). Variabel lain, seperti kelembaban tanah dan radiasi matahari, diukur berdekatan dengan tiap lokasi sumur pantau. 


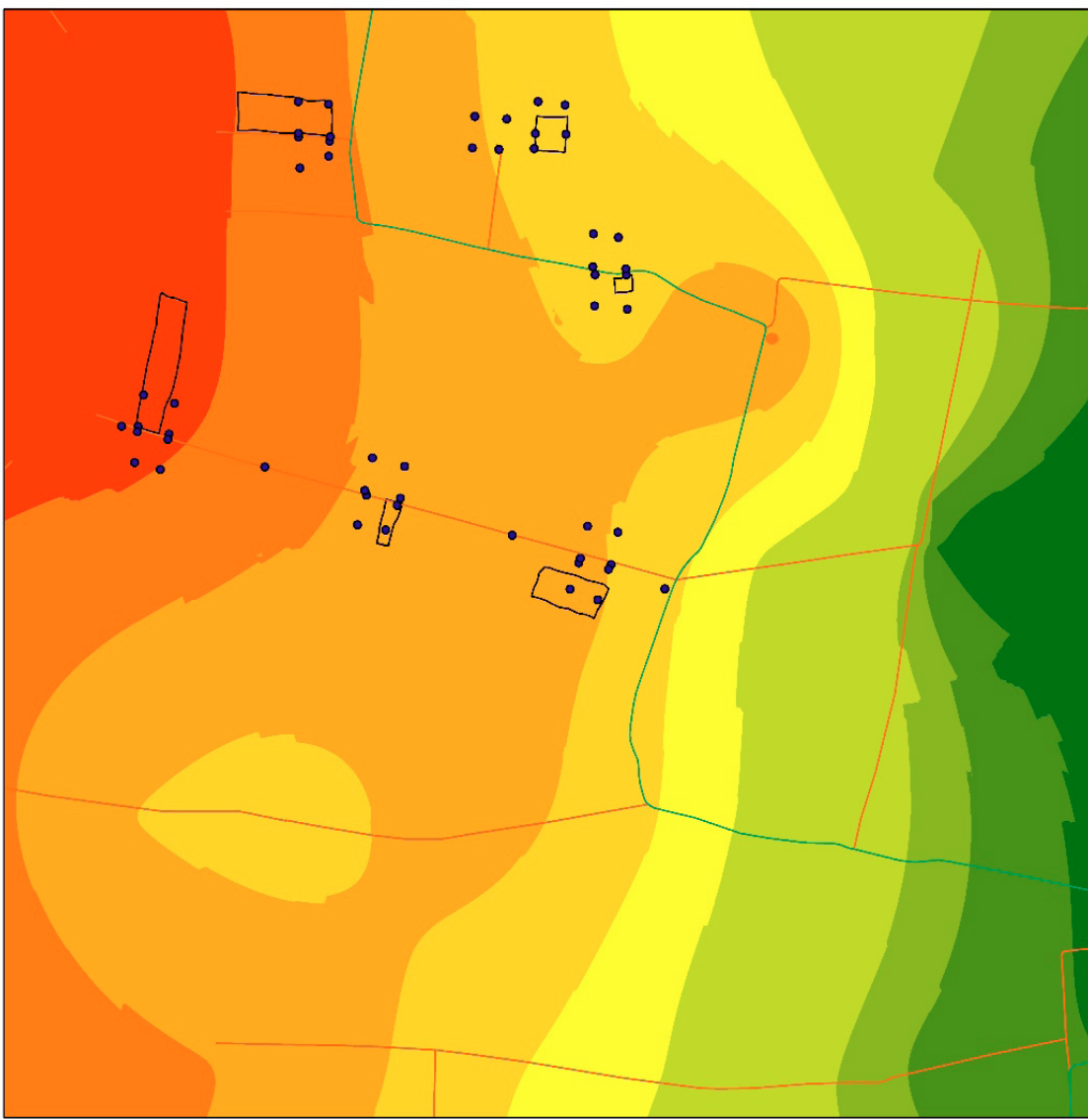

Sumur Pantau TMA,

Dompas, Tg. Batu,

Bengkalis, Riau

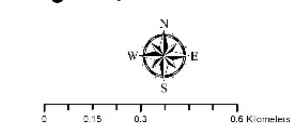

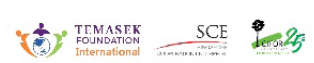

Legenda

- Sumur Pantau

_ Jalan Provinsi

_ Jalan Desa

$\square$ Batas Arena Aksi

Peat depth (m)

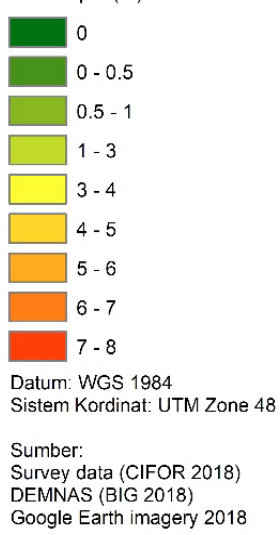

Gambar 4.20 Sebaran 48 sumur pantau tinggi muka air tanah gambut (TMA) di Desa Dompas pada enam lokasi arena aksi dan kontrolnya. 


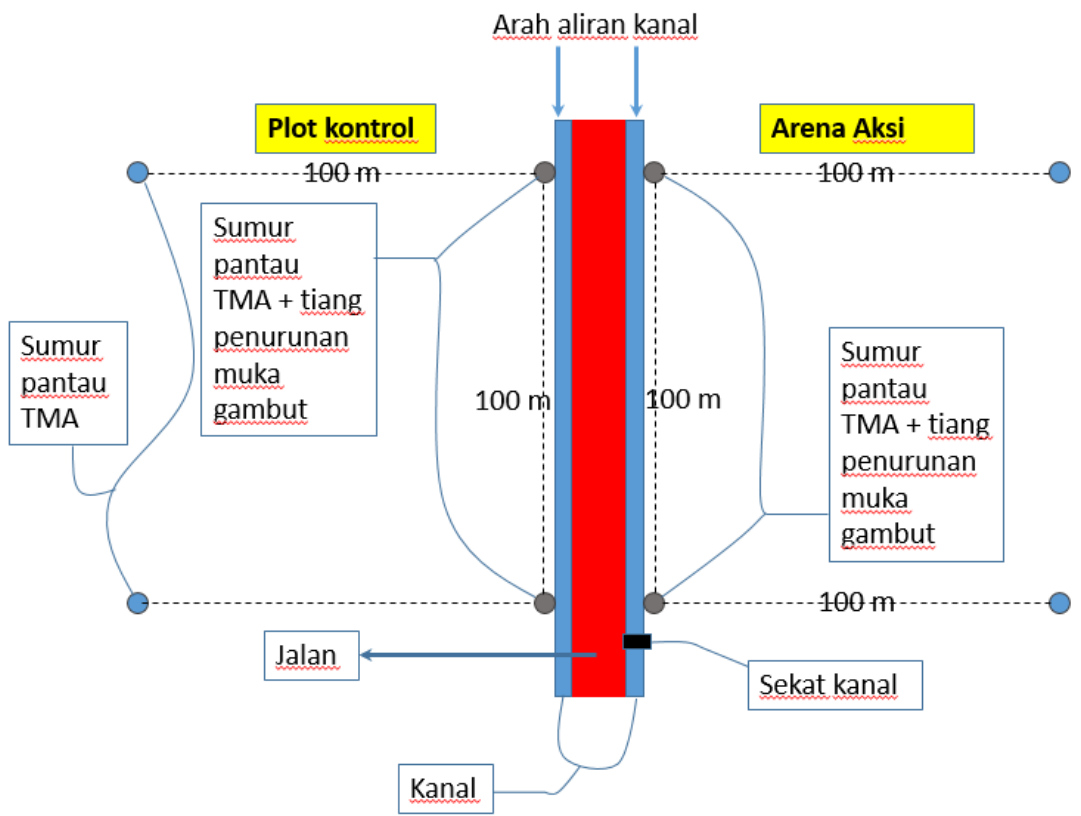

Gambar 4.21 Desain pemantauan dampak sekat kanal terhadap tinggi muka air tanah, kelembaban tanah, radiasi matahari, dan penurunan permukaan lahan gambut.

- Alat dan Bahan:

\begin{tabular}{cll}
\hline No & \multicolumn{1}{c}{ Alat dan Bahan } & \multicolumn{1}{c}{ Penggunaan } \\
\hline 1 & GPS & Untuk menentukan posisi geografi sumur pantau \\
\hline 2 & Bor tangan listrik & Untuk melubangi pipa sumur pantau \\
\hline 3 & Gergaji & Untuk menajamkan ujung pipa sumur pantau \\
\hline 4 & Pipa PVC & Tiang pipa sumur pantau \\
\hline 5 & Bor Eijkelkamp & Untuk melubangi gambut lubang pipa sumur pantau \\
\hline 6 & Meteran (50 m) & Pengukur jarak \\
\hline 7 & Spidol permanen & Penanda ukuran jarak pada tongkat ukur \\
\hline 8 & Tongkat ukur & Pengukur tinggi muka air tanah dalam pipa \\
\hline 9 & Pita penanda & Penanda lokasi sumur pantau \\
\hline 10 & Kawat besi & Tiang penanda lokasi sumur pantau \\
\hline 11 & Alat uji tanah portabel & Pengukur kelembaban tanah \\
\hline 12 & Besi beton & Tiang ukur penurunan permukaan lahan gambut \\
\hline
\end{tabular}




\section{- Pembuatan sumur pantau}

Pipa PVC berdiameter 2 inci dipotong sepanjang sekitar $3 \mathrm{~m}$ dan ditajamkan pada satu ujungnya. Tiap pipa dilubangi dengan bor tangan sepanjang badan pipa, dengan diameter $1 \mathrm{~cm}$ dan jarak $25 \mathrm{~cm}$ antar lubang. Sisi bagian bawah ditutup dengan penutup pipa yang sudah dilubangi dasarnya. Pada lokasi pengukuran, tanah gambut dilubangi hingga kedalaman $3 \mathrm{~m}$, kemudian pipa PVC ditancapkan sebagai sumur pantau. Sisakan pipa di atas tanah sepanjang $20 \mathrm{~cm}$, dan diberi tutup yang mudah dibuka (Gambar 4.22). Pipa diberi tanda kode arena aksi dan nomor sumur pantau.

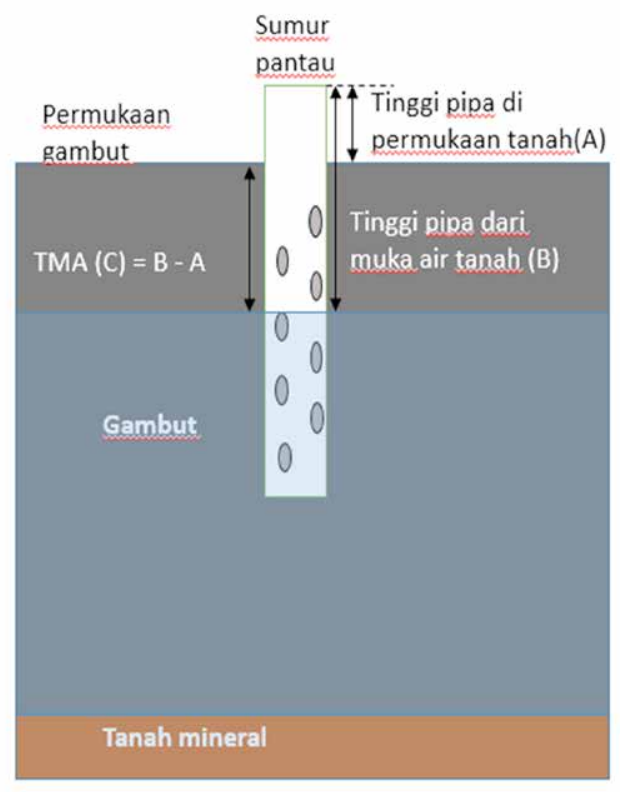

\section{Gambar 4.22 Penampang sumur pantau yang dipasang pada arena-arena aksi di lahan gambut Desa Dompas.}

\section{- Pengukuran lapangan}

Tinggi muka air tanah diukur relatif terhadap permukaan gambut, menggunakan meteran dan tongkat pengukur. Pertama, ukur tinggi muka air dari puncak pipa sumur pantau (C; Gambar 4.22), dilanjutkan dengan mengukur tinggi sisa pipa di atas permukaan tanah (B). Tinggi muka air tanah adalah selisih antara C dan B.

Contoh hasil pengukuran dapat dilihat pada Gambar 4.23. Dampak pembangunan sekat kanal dapat dilihat dengan lebih dangkalnya tinggi muka air tanah di arena aksi dibandingkan dengan di lokasi kontrol/referensi, sepanjang tahun. 


\section{Ground Water Level Monitoring}

Arena 01

- Action

- Contral

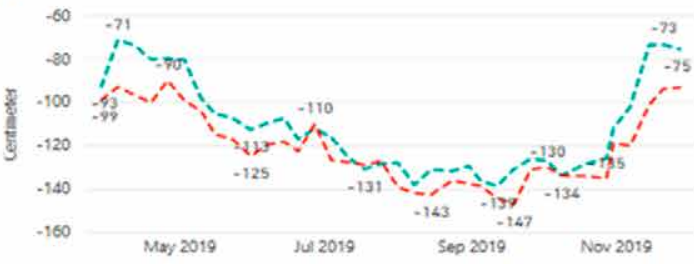

Arena 03

- Action

- Control

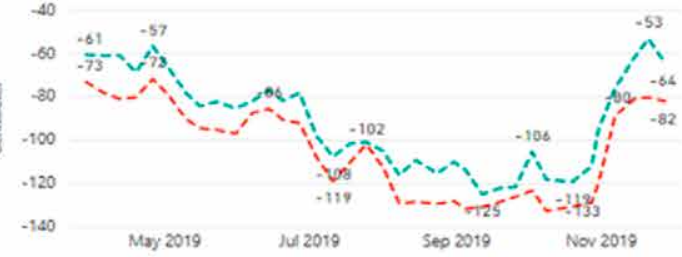

Arena 05

- Action

- control

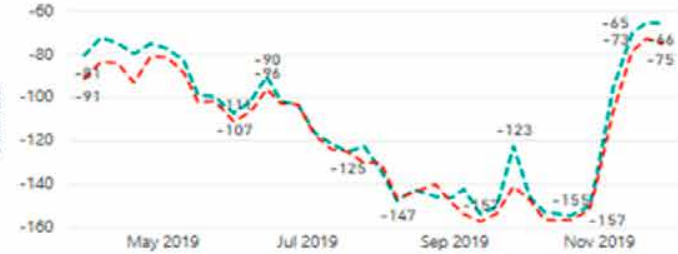

Arena 02

- Action

- Consol

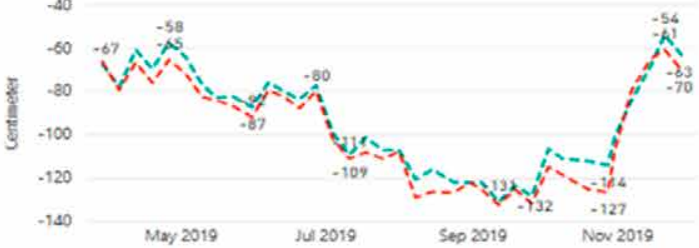

Arena 04

- Action

- Contral

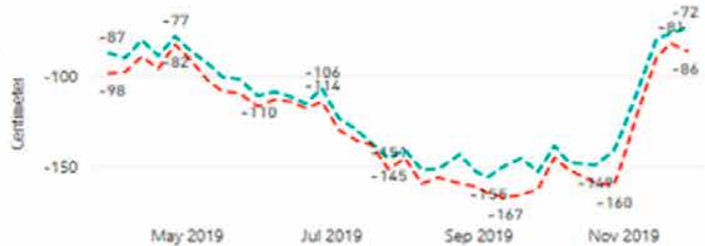

Arena 06

- Action

- Control

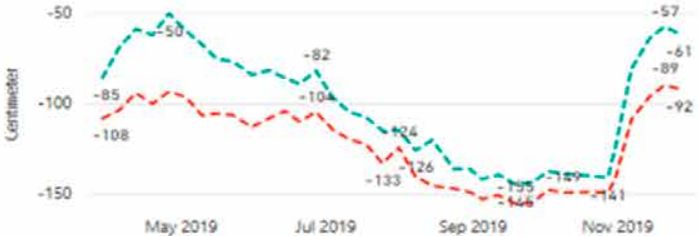

Gambar 4.23 Hasil pengukuran tinggi muka air tanah gambut selama delapan bulan. Garis putus-putus biru adalah TMA di arena aksi, lebih dangkal dari TMA di plot control (garis putus-putus merah). 


\subsubsection{Pengukuran penurunan permukaan lahan gambut}

Empat tiang ukur penurunan permukaan gambut dibuat dan dipasang di sekitar lokasi sekat kanal. Tiang-tiang ukur tersebut terbuat dari besi beton yang panjangnya $1 \mathrm{~m}$ lebih panjang dari total kedalaman gambut, agar dapat menembus lapisan tanah mineral di bawahnya ketika ditancapkan ke tanah gambut (Gambar 4.24). Sisakan tiang ukur $50 \mathrm{~cm}$ di atas tanah, yang sekaligus menjadi data pertama pemantauan penurunan permukaan tanah gambut. Pengukuran berikutnya akan dilakukan pada akhir kegiatan, sehingga selisih ketinggian tiang ukur pada pengukuran pertama dan kedua merupakan besar penurunan permukaan gambut selama periode waktu di antara kedua pengukuran. Keamanan lokasi tiang ukur perlu dijaga agar tidak terganggu oleh kegiatan sehari-hari masyarakat, atau oleh binatang. Pembuatan pagar merupakan salah satu alternatif upaya pengamanan tiang ukur.

Tiang ukur pertama dipasang pada jarak 5 m di sebelah hulu sekat kanal, sekitar $1 \mathrm{~m}$ dari dinding kanal terdekat. Tiang ukur kedua dipasang pada jarak $100 \mathrm{~m}$ di sebelah hulu tiang ukur pertama. Tiang ketiga dan keempat dipasang di wilayah kontrol/referensi, berseberangan dengan tiang di lokasi arena aksi dengan jarak $1 \mathrm{~m}$ dari dinding kanal terdekat (Gambar 4.24).

\section{- Alat dan Bahan:}

\begin{tabular}{cll}
\hline No & \multicolumn{1}{c}{ Alat dan Bahan } & \multicolumn{1}{c}{ Penggunaan } \\
\hline 1 & GPS & Untuk menentukan posisi geografi sumur pantau \\
\hline 2 & Gergaji tangan & Untuk memotong besi beton \\
\hline 3 & Besi beton & Bahan tiang ukur \\
\hline 4 & Meteran gulung $(50 \mathrm{~m})$ & Untuk mengukur jarak \\
\hline 5 & Pita penanda & Untuk menandai lokasi pengukuran \\
\hline 6 & Kawat besi & Untuk menandai lokasi pengukuran \\
\hline 7 & Tiang ukur & Untuk mengukur ketinggian tiang ukur \\
\hline 8 & Besi beton & Tiang ukur penurunan permukaan lahan gambut \\
\hline
\end{tabular}




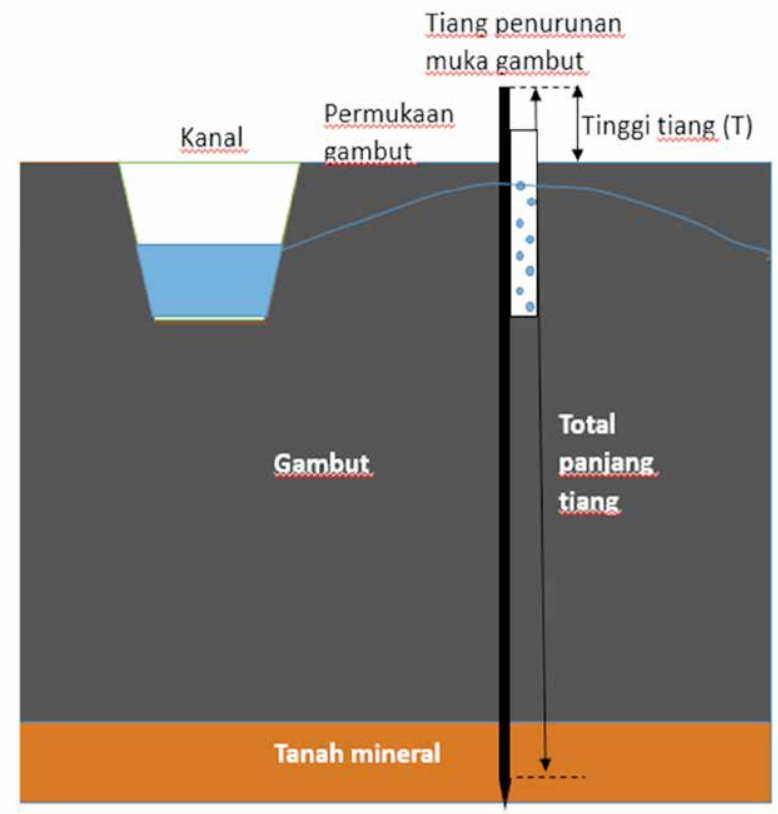

Gambar 4.24 Tiang ukur penurunan permukaan gambut dipasang $1 \mathrm{~m}$ dari dinding terdekat kanal.

\subsection{PUSTAKA}

Agus F, Hairiah K, dan Mulyani A. 2011. Pengukuran Cadangan Karbon Tanah Gambut. Petunjuk Praktis. Bogor, Indonesia: World Agroforestry Centre-ICRAF, SEA Regional Office.

BRG. 2016. Rencana Strategis Badan Restorasi Gambut 2016 - 2020. Jakarta: Badan Restorasi Gambut (BRG).

Chimner RA, Ott CA, Perry CH, dan Kolka RK. 2014. Developing and evaluating rapid field methods to estimate peat carbon. Wetlands, 34(6): 1241-1246.

Dohong A, Cassiophea L, Sutikno S, Triadi BL, Wirada F, Rengganis P, dan Sigalingging L. 2017. Modul Pelatihan: Pembangunan Infrastruktur Pembasahan Gambut Sekat Kanal Berbasis Masyarakat. Jakarta: Kedeputian Bidang Konstruksi, Operasi dan Pemeliharaan, Badan Restorasi Gambut Republik Indonesia. 
Kauffman JB, Arifanti VB, Basuki I, Kurnianto S, Novita N, Murdiyarso D, Donato DC, dan Warren MW. 2016. Protocols for the measurement, monitoring, and reporting of structure, biomass, carbon stocks and greenhouse gas emissions in tropical peat swamp forests. Bogor, Indonesia: Center for International Forestry Research (CIFOR).

Oliver, M. A. "Kriging: A Method of Interpolation for Geographical Information Systems." International Journal of Geographic Information Systems 4: 313-332. 1990.

Ritung S, Wahyunto, Nugroho K, Sukarman, Hikmatullah, Suparto, dan Tafakresnanto C. 2011. Peta Lahan Gambut Indonesia Skala 1:250.000 (Indonesian peatland map at the scale 1:250,000). Bogor, Indonesia: Indonesian Center for Agricultural Land Resources Research and Development.

Ritzema H, Limin S, Kusin K, Jauhiainen J, dan Wösten H. 2014. Canal blocking strategies for hydrological restoration of degraded tropical peatlands in Central Kalimantan, Indonesia. Catena, 114: 11-20. 


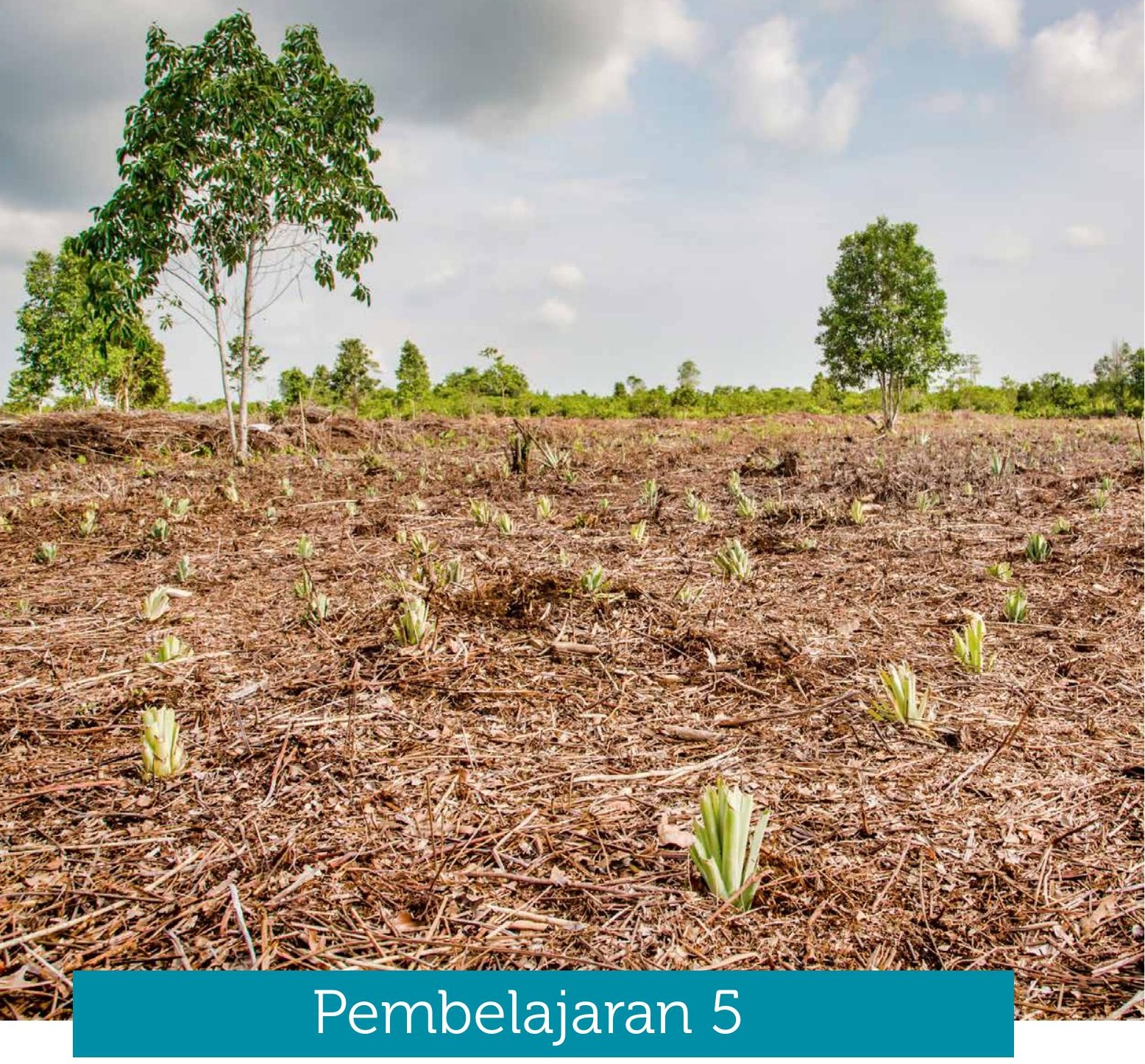

\section{Penyiapan Lahan Tanpa Bakar untuk Pencegahan Kebakaran Hutan dan Lahan}

Nurul Qomar, Ahmad Muhammad, Qori Pebrial Ilham, Hari Priyadi Rusantoyo dan Lailan Syaufina 
Bencana kabut-asap (haze) sejak dua dasawarsa terakhir telah menimbulkan keresahan masyarakat dalam skala luas, baik di tingkat lokal, nasional, maupun internasional. Sumber kabut-asap tidak lain adalah kebakaran lahan dan hutan, khususnya lahan gambut. Kebakaran lahan gambut sering dipicu oleh proses pembukaan dan penyiapan lahan gambut untuk budidaya tanaman tertentu. Hal ini dikarenakan sebagian anggota masyarakat masih memandang bahwa penggunaan api dalam penyiapan lahan sangat praktis, efektif, dan ekonomis. Dengan semakin ketatnya larangan penggunaan api dalam penyiapan lahan akhir-akhir ini, masyarakat menjadi lebih waswas untuk membakar lahan dan memilih cara-cara lain yang tidak melanggar hukum. Meskipun demikian, beberapa cara penyiapan lahan tanpa bakar (PLTB) mempunyai kendala sehingga belum sepenuhnya dilaksanakan oleh masyarakat, seperti keterbatasan pengetahuan, teknologi, dan biaya.

Penyiapan lahan merupakan kegiatan membuka, membersihkan lahan, dan mengendalikan kesuburan tanah agar tercipta ruang dan kondisi lahan yang optimal sehingga lebih sesuai untuk membudidayakan tanaman tertentu. Kegiatan ini merupakan tahapan yang cukup penting untuk mencapai keberhasilan usaha dari komoditas yang dibudidayakan karena penyiapan lahan yang tepat akan menciptakan kondisi yang kondusif bagi pertumbuhan tanaman (Nugroho 2012).

Penyiapan lahan dengan cara membakar, baik oleh masyarakat petani, pengusaha perkebunan, dan pengusaha hutan tanaman, sering dilakukan karena mudah, murah, dan cepat (Hendromono dkk. 2007). Anshari dkk. (2010) juga menyebutkan bahwa penyiapan lahan gambut untuk pertanian kecil umumnya dilakukan dengan pembakaran. Hal ini dilakukan karena pembakaran lahan juga dipercaya dapat membantu menghilangkan hama dan penyakit tanaman, mengurangi keasaman tanah, dan dapat menyuburkan tanah. Oleh karenanya praktek pembakaran dalam rangka penyiapan lahan untuk budidaya tanaman masih sering dijumpai di kalangan petani kecil.

Metode pembakaran lahan memiliki beberapa keuntungan, yaitu mudah dan sederhana untuk dilakukan, tidak perlu alat berat, bisa dilakukan di berbagai kemiringan lahan, cepat melepaskan hara khususnya $\mathrm{P}, \mathrm{K}, \mathrm{Ca}$, dan Mg, mematikan hama dan penyakit tanaman, menekan pertumbuhan gulma berdaun lebar, lebih murah dalam jangka pendek, serta abu yang dihasilkan dapat digunakan untuk pupuk (Hendromono dkk. 2007). Namun, kerugian yang ditimbulkan jauh lebih besar jika dibandingkan keuntungan tersebut. Banyak penelitian menyebutkan bahwa kebakaran hutan dan lahan, terutama di gambut, menyebabkan degradasi atau kerusakan lingkungan, perubahan iklim, mengganggu kesehatan manusia, serta merugikan aspek sosial dan ekonomi (Hermawan 2006; Subiksa dkk. 2011; Yuliani dkk. 2019). Penyiapan lahan dengan metode pembakaran kurang menguntungkan dalam jangka panjang karena ketersediaan unsur hara dari pembakaran limbah pembukaan lahan lebih sedikit dan 
Kotak 5.1 Beberapa peraturan terkait dengan larangan membakar lahan dan hutan

\section{UU Nomor 41 Tahun 1999 tentang Kehutanan.}

Pasal 50 Ayat (3) huruf d "Setiap orang dilarang membakar hutan"

Pasal 50 Ayat (3) huruf I "Setiap orang dilarang membuang benda-benda yang dapat menyebabkan kebakaran dan kerusakan serta membahayakan keberadaan atau kelangsungan fungsi hutan ke dalam kawasan hutan".

Pasal 78 Ayat (3) "Barang siapa dengan sengaja melanggar ketentuan sebagaimana dimaksud dalam Pasal 50 ayat (3) huruf d, diancam dengan pidana penjara paling lama 15 (lima belas) tahun dan denda paling banyak Rp 5.000.000.000,00 (lima milyar rupiah)".

Pasal 78 Ayat (4) "Barang siapa karena kelalaiannya melanggar ketentuan sebagaimana dimaksud dalam Pasal 50 ayat (3) huruf d, diancam dengan pidana penjara paling lama 5 (lima) tahun dan denda paling banyak Rp 1.500.000.000,00 (satu milyar lima ratus juta rupiah).

\section{UU Nomor 32 Tahun 2009 tentang Perlindungan dan Pengelolaan Lingkungan hidup.}

Pasal 69 ayat (1) huruf h UU PPLH; "Setiap orang dilarang melakukan pembukaan lahan dengan cara membakar".

Pasal 108; "Setiap orang yang melakukan pembakaran lahan sebagaimana dimaksud dalam Pasal 69 ayat (1) huruf h, dipidana dengan pidana penjara paling singkat 3 (tiga) tahun dan paling lama 10 (sepuluh) tahun dan denda paling sedikit Rp 3.000.000.000,00 (tiga miliar rupiah) dan paling banyak Rp 10.000.000.000,00 (sepuluh miliar rupiah)".

\section{UU Nomor 39 Tahun 2014 tentang Perkebunan.}

Pasal 56 Ayat (1) "Setiap Pelaku Usaha Perkebunan dilarang membuka dan/ atau mengolah lahan dengan cara membakar".

Pasal 108 "Setiap Pelaku Usaha Perkebunan yang membuka dan/atau mengolah lahan dengan cara membakar sebagaimana dimaksud dalam Pasal 56 ayat (1) dipidana dengan pidana penjara paling lama 10 (sepuluh) tahun dan denda paling banyak Rp 10.000.000.000,00 (sepuluh miliar rupiah)". 
cepat hilang karena tercuci. Selain itu, limbah yang terbakar tidak bisa dimanfaatkan menjadi barang yang lebih bernilai, misalnya untuk pembuatan arang dan kompos.

Berdasarkan hal tersebut, untuk menanggulangi kebakaran hutan dan lahan, Pemerintah Indonesia menyusun kebijakan yang melarang kegiatan penyiapan lahan dengan cara pembakaran. Sebagaimana yang dicantumkan dalam Undang-Undang No. 39 Tahun 2014 tentang Perkebunan Pasal 56: "setiap pelaku usaha perkebunan dilarang membuka dan/atau mengolah lahan dengan cara membakar". Oleh karena itu, diperlukan upaya-upaya untuk meningkatkan pemahaman tentang bahaya penyiapan lahan dengan pembakaran, mengubah sikap dan perilaku dalam pengolahan lahan untuk kepentingan bersama, serta perlu menghitung biaya penyiapan lahan dengan mempertimbangkan risiko terjadinya bencana kebakaran.

\section{Kotak 5.2 Kebakaran di lahan gambut}

Kebakaran lahan dan hutan sering terjadi di lahan gambut yang didrainase (pengatusan air) dan digunakan untuk budidaya tanaman. Lahan gambut yang sudah didrainase mengalami penurunan muka air tanah dan mempunyai kelembaban tanah yang sangat rendah, sehingga pada musim kemarau sangat rentan terjadi kebakaran. Lahan gambut merupakan akumulasi biomassa sehingga apabila terbakar akan sangat sulit dipadamkan mengingat melimpahnya bahan bakar dan kebakaran terjadi di bawah permukaan tanah. Seiring dengan peningkatan aksesibilitas wilayah, banyak dilakukan pembukaan lahan baru di lahan gambut untuk perkebunan (khususnya kelapa sawit), baik oleh rakyat, pemilik modal (cukong), maupun perusahaan. Meskipun tergolong lahan marginal, lahan gambut banyak diusahakan untuk budidaya tanaman karena kesempatan untuk membuka lahan mineral semakin terbatas dan semakin mahalnya harga tanah. Kebiasaan masyarakat dan pengusaha perkebunan yang menyiapkan lahan dengan cara membakar masih banyak dilakukan, mengingat biaya yang lebih murah dibandingkan dengan cara mekanis yang menggunakan alat berat.

Riau adalah provinsi di Sumatera dengan lahan gambut terluas, yaitu mencapai kurang lebih 4 juta hektar. Salah satu kawasan gambut yang sering terbakar adalah Kesatuan Hidrologis Gambut (KHG) Sungai Rokan - Sungai Siak Kecil, yang di dalamnya terdapat Desa Dompas, yang terletak di Kecamatan Bukit Batu, Kabupaten Bengkalis. Pada periode 2014 - 2019, kebakaran lahan dan hutan di KHG ini terjadi setiap tahun. Kebakaran paling luas terjadi pada tahun 2014, dengan jumlah hotspots sebanyak 1.336 titik (pada tingkat kepercayaan 0-100\%). Pada tahun 2018 dan 2019, kebakaran masih terjadi juga di Desa Dompas dengan jumlah hotspots sebanyak 8 dan 17 titik. 


\section{Kotak 5.2 sambungan}

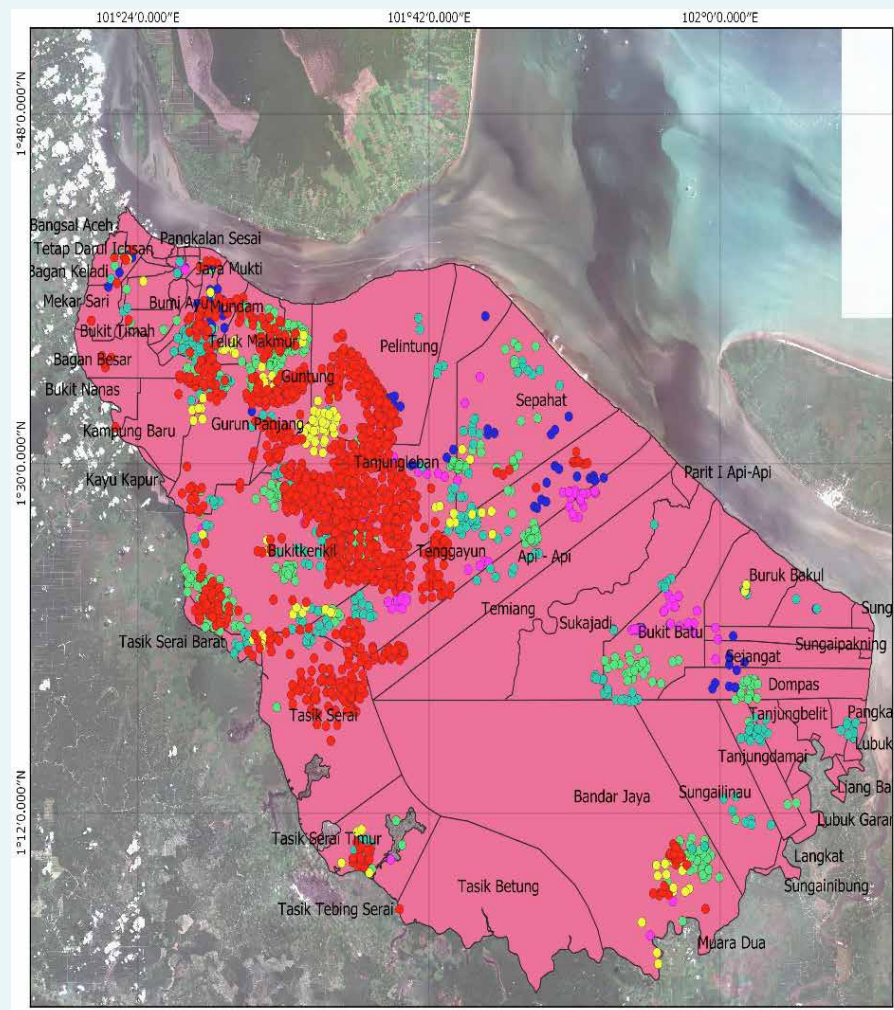

Peta Sebaran Hotspot Tahun 2014 - 2019 di KHG Sungai

Rokan - Sungai Siak Kecil Provinsi Riau

\begin{tabular}{|l|}
\hline \multicolumn{2}{|c|}{ Skala : 450.000} \\
\hline \hline Legenda : \\
- Hotspot Tahun 2014 \\
- Hotspot Tahun 2015 \\
- Hotspot Tahun 2016 \\
- Hotspot Tahun 2017 \\
- Hotspot Tahun 2018 2019 \\
$\square$ Batas Desa Di KHG SR-SSK \\
\hline
\end{tabular}

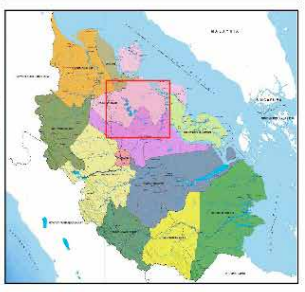

Sumber:

Rupa Bumi Indonesia InaGeospasia Hotspot Tingkat Kepercayaan $0-100 \%$ Tahun 2014-2019 LAPAN

\section{Gambar 5.1 Peta sebaran hotspots di KHG Sungai Rokan - Sungai Siak Kecil periode 2014 - 2019}

Sumber: Data Sensor Modis pada tingkat kepercayaan 0-100\% yang telah diolah oleh LAPAN ${ }^{6}$

Bulan yang paling rawan terjadi kebakaran dalam 5 tahun terakhir adalah bulan Februari - Maret. Bulan Februari - Maret merupakan musim kemarau pertama di Riau, dengan curah hujan rendah. Masa rawan kebakaran berikutnya adalah selama musim kemarau kedua, yaitu pada bulan Juli - September.

6 http://modis-catalog.lapan.go.id/monitoring/hotspot/index (diakses 29 Desember 2019) 
Kotak 5.2 sambungan

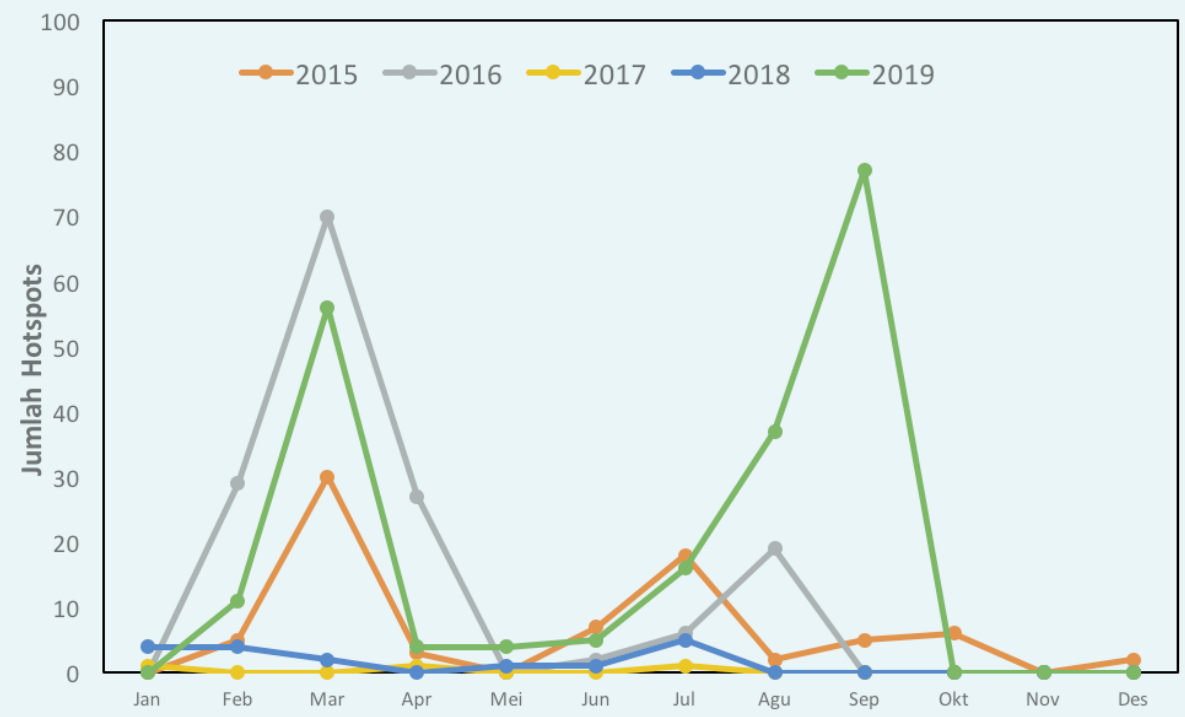

\section{Gambar 5.2 Sebaran jumlah hotpots di KHG Sungai Rokan- Sungai Siak Kecil menurut bulan pada periode 2014-2019}

Sumber: Data Sensor Modis pada tingkat kepercayaan $>70 \%$ yang telah diolah oleh $\operatorname{LAPAN}^{7}$

Penyiapan Lahan Tanpa Bakar (PLTB) merupakan bagian dari upaya pengelolaan lahan secara berkelanjutan. PLTB sebagai teknik pembukaan lahan tanpa pembakaran dapat dilakukan untuk pertanian di lahan gambut dan bisa dikerjakan secara terus menerus tanpa sistem bera (Sunanto 2008). Penerapan PLTB akan mengurangi hilangnya cadangan karbon, subsiden, dan pada akhirnya mengarah pada konservasi gambut (Yulianti dan Adji 2018).

Secara umum, kegiatan PLTB dapat dikelompokkan menjadi beberapa tahapan, yaitu persiapan, penebasan dan penebangan, pembersihan lahan, pemanfaatan limbah, pengolahan lahan, konservasi lahan, dan pencegahan kebakaran. Tjahjono (1999) menyebutkan bahwa PLTB dilakukan dengan cara tebang dan tebas, pilah dan kumpul, kemudian pemanfaatan sisa tebangan menjadi produk yang bernilai ekonomis. Sisa vegetasi dapat dimanfaatkan untuk briket dan arang aktif. Untuk membasmi gulma yang tumbuh setelah dilakukan penebasan vegetasi, PLTB juga memerlukan bantuan herbisida (Noor 2010). 


\subsection{METODE-METODE PENYIAPAN LAHAN TANPA BAKAR (PLTB)}

Peralihan metode penyiapan lahan dari cara membakar ke tanpa bakar memerlukan alternatif yang bisa diterima oleh masyarakat. Secara garis besar, terdapat dua metode PLTB, yaitu secara manual dan mekanis. Meskipun demikian, dalam penerapannya kedua metode ini juga bisa dikombinasikan. Menurut Hendromono dkk. (2007), cara penyiapan lahan ditentukan terutama oleh jenis vegetasi (penutupan lahan) awal dan persyaratan tumbuh jenis yang akan ditanam. Tipe penutupan lahan awal menentukan kebutuhan teknologi, tenaga, waktu, dan biaya dalam penyiapan lahan. Tutupan lahan dapat diklasifikasikan berdasarkan tipe vegetasi dominan, misalnya hutan dengan pohon yang rapat, semak berkayu, dan semak tidak berkayu (paku-pakuan, rumput, alang-alang, dan perdu daun lebar). Jenis tanaman yang akan dibudidayakan menentukan kondisi persyaratan tumbuh tanaman tersebut, seperti kebutuhan terhadap naungan atau penyinaran, kebutuhan terhadap drainase atau tingkat kebasahan lahan, kebutuhan terhadap ruang di atas atau di bawah permukaan tanah, serta kebutuhan terhadap perlakuan pengolahan tanah atau substrat.

Selain itu, pilihan metode PLTB juga perlu mempertimbangkan jenis lahan dan kondisi topografi, peralatan dan tenaga yang tersedia, biaya, serta dampaknya terhadap kondisi lahan dan masyarakat. Penggunaan lahan gambut untuk budidaya tanaman memerlukan pengaturan tingkat drainase dalam penyiapan lahan, mengingat drainase yang tidak terkendali akan meningkatkan ancaman kebakaran hutan dan lahan. Kemiringan lahan juga menjadi faktor penentu untuk memilih metode PLTB yang digunakan. Pembersihan lahan di areal yang kemiringannya kurang dari 15\% dapat dilakukan dengan menginjak alang-alang menggunakan traktor atau bulldozer. Pada areal yang kemiringannya 16\% sampai 20\%, perlu dibuat jalur tumpukan limbah yang sejajar garis kontur. Apabila kemiringan lahan lebih dari 20\%, yang berarti risiko erosi cukup besar, maka dapat dilakukan penyemprotan dengan herbisida (Hendromono dkk. 2007).

Sebagai pendekatan untuk restorasi gambut, penyiapan lahan juga perlu mempertimbangkan prinsip-prinsip yang ramah gambut. Prinsip-prinsip tersebut adalah: tidak menggunakan api, tidak melakukan pengeringan gambut, tidak menggunakan alat berat, meminimalkan penebangan pohon, meminimalkan penggunaan pupuk, meminimalkan penggunaan herbisida, mengoptimalkan pemanfaatan mulsa, mengoptimalkan jarak tanam, mengoptimalkan tutupan pohon, meningkatkan produktivitas lahan, meningkatkan pendapatan petani, dan meningkatkan keberlanjutan.

Berdasarkan prinsip-prinsip dan pertimbangan di atas maka ada tiga metode PLTB yang dapat dipilih (Tabel 5.1), yaitu: 1) secara manual (tebang imas), 2) secara mekanis ringan, dan 3) secara mekanis berat. Secara manual, peralatan yang digunakan bisa 
berupa parang, kapak, atau chainsaw. Dengan cara ini, penebasan bisa dilakukan secara menyeluruh maupun tidak menyeluruh. Hal ini tergantung pada karakteristik jenis tanaman yang akan dibudidayakan, sistem penanaman, serta pertimbangan terkait jenis peralatan, jumlah tenaga kerja, waktu yang tersedia, serta luas dan kondisi lahan. PLTB secara manual bersifat padat karya sehingga dapat menyerap tenaga kerja lokal. Secara mekanis ringan, peralatan yang diperlukan adalah hand tractor. Pembersihan vegetasi dengan teknik ini dapat dilakukan apabila tutupan lahan hanya didominasi oleh rumput-rumputan dan paku-pakuan, tidak banyak mengandung semak berkayu, serta jika petani memiliki akses untuk penggunaan hand tractor. Secara mekanis berat, peralatan yang digunakan adalah excavator atau bulldozer. Teknik ini dapat digunakan jika pada lahan yang akan dibudidayakan terdapat banyak pohon dan tunggul pohon, serta jika petani memiliki biaya untuk menyewa alat berat tersebut. Masing-masing metode mempunyai kelebihan dan kekurangan (Tabel 5.2), sehingga pemilihannya dapat disesuaikan dengan situasi dan kondisi setempat.

\section{Tabel 5.1 Metode-metode PLTB}

\begin{tabular}{ccl}
\hline No. & Pilihan Metode & \\
\hline 1 & Manual & $\begin{array}{l}\text { Penebangan dan penebasan vegetasi dengan parang } \\
\text { dan kapak (tebang imas), dan dapat dikombinasikan } \\
\text { dengan gergaji mesin (chain saw). Dilakukan apabila } \\
\text { pada vegetasi penutup lahan terdapat banyak tumbuhan } \\
\text { berkayu, baik berupa semak maupun pohon, dan petani } \\
\text { tidak memiliki akses terhadap penggunaan alat berat. }\end{array}$ \\
\hline 2 Mekanis Ringan & $\begin{array}{l}\text { Pembersihan vegetasi dengan traktor tangan atau traktor } \\
\text { mini yang dapat dikombinasikan dengan mesin pemotong } \\
\end{array}$ \\
& $\begin{array}{l}\text { rumput Dilakukan apabila vegetasi penutup lahan hanya } \\
\text { didominasi rumput-rumputan dan paku-pakuan, tidak } \\
\text { banyak mengandung semak berkayu, serta petani } \\
\text { memiliki akses terhadap penggunaan traktor tangan }\end{array}$ \\
\hline 3 & Mekanis Berat & $\begin{array}{l}\text { Pembersihan dengan alat berat (excavator dan atau } \\
\text { bulldozer). Dilakukan apabila pada lahan terdapat banyak } \\
\text { pohon, tunggul pohon, batang pohon, dan petani memiliki } \\
\text { biaya dan akses untuk menyewa alat berat. }\end{array}$ \\
\hline
\end{tabular}


Tabel 5.2 Kelebihan dan kekurangan beberapa pilihan metode PLTB

\begin{tabular}{|c|c|c|c|c|}
\hline No. & Potensi & Tebang Manual & Mekanis Ringan & Mekanis Berat \\
\hline 1 & Kelebihan & $\begin{array}{l}\text { - Penyerapan } \\
\text { tenaga kerja lebih } \\
\text { banyak } \\
\text { - Penciptaan } \\
\text { wahana } \\
\text { keguyuban } \\
\text { komunitas } \\
\text { - Pemeliharaan } \\
\text { sistem ekologis } \\
\text { yang ada }\end{array}$ & $\begin{array}{l}\text { - Penghematan } \\
\text { waktu dan } \\
\text { biaya tenaga } \\
\text { kerja } \\
\text { - Pemeliharaan } \\
\text { sistem } \\
\text { ekologis yang } \\
\text { ada }\end{array}$ & $\begin{array}{l}\text { - Penghematan } \\
\text { waktu (dan biaya } \\
\text { jika dalam skala } \\
\text { luas) } \\
\text { - Lebih efektif } \\
\text { membersihkan } \\
\text { dan meratakan } \\
\text { lahan }\end{array}$ \\
\hline 2 & Kekurangan & $\begin{array}{l}\text { - Membutuhkan } \\
\text { tenaga kerja lebih } \\
\text { banyak } \\
\text { - Membutuhkan } \\
\text { waktu lebih lama } \\
\text { - Menghadapi } \\
\text { kendala dalam } \\
\text { pemindahan } \\
\text { material tebasan } \\
\text { yang berat }\end{array}$ & $\begin{array}{l}\text { - Membutuhkan } \\
\text { perlatan yang } \\
\text { kemungkinan } \\
\text { tidak tersedia } \\
\text { di masyarakat } \\
\text { - Menghadapi } \\
\text { kendala } \\
\text { pemindahan } \\
\text { material } \\
\text { tebasan yang } \\
\text { berat }\end{array}$ & $\begin{array}{l}\text { - Membutuhkan } \\
\text { peralatan yang } \\
\text { kemungkinan } \\
\text { tidak terjangkau } \\
\text { oleh masyarakat } \\
\text { - Membutuhkan } \\
\text { jalan akses yang } \\
\text { sesuai untuk alat } \\
\text { berat } \\
\text { - Memiliki potensi } \\
\text { merusak gambut }\end{array}$ \\
\hline
\end{tabular}

\subsection{PLTB SECARA MANUAL/TEBANG IMAS}

Untuk membantu masyarakat dalam menyiapkan lahan skala kecil, maka dalam tulisan ini akan dipaparkan tahapan-tahapan PLTB dengan cara manual atau tebang imas, yang terdiri dari penebangan pohon, penebasan semak, penumpukan biomassa, pemanfaatan material hasil tebasan, pengendalian gulma, serta pembuatan perigi.

\section{a. Penebangan pohon}

Pada lahan yang banyak ditumbuhi pohon, kegiatan yang penting dilakukan adalah penebangan dan pemanfaatan kayu. Penebangan pohon bisa dilakukan secara terpilih/selektif menurut jenis, ukuran, posisi ataupun tebang habis secara menyeluruh, tergantung kepada jenis tanaman yang akan dibudidayakan. Jika diinginkan integrasi dengan upaya percepatan restorasi gambut, maka pohon jenis-jenis asli (native species) dapat dipertahankan sebagai penutup lahan. 

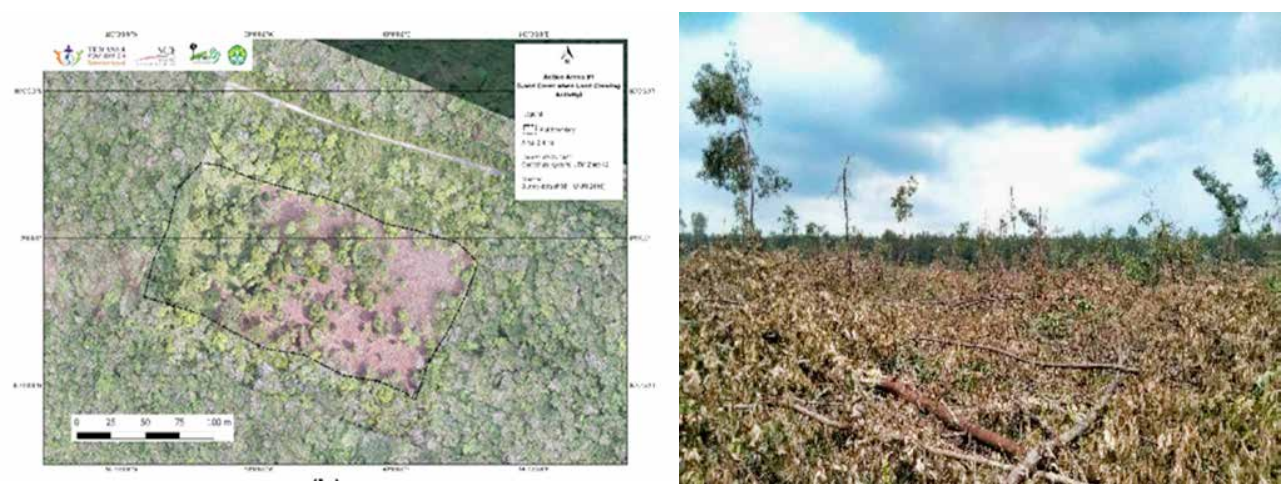

\section{Gambar 5.3 Kondisi lahan setelah penebangan pohon secara selektif, tampak secara horisontal dan vertikal}

Penebangan pohon bisa dilakukan dengan gergaji atau chainsaw, dengan tinggi tunggul/tunggak yang diusahakan serendah mungkin. Batang bagian bawah hingga cabang pertama dapat dimanfaatkan untuk kayu gergajian, sedangkan batang di atas cabang pertama bisa dimanfaatkan untuk bahan baku chip/pulp atau bahan baku papan partikel. Ranting kecil dan daun dapat dicincang kemudian dilapukkan untuk dijadikan kompos. Bagian akar dan batang bawah yang tidak sesuai untuk dijadikan kayu gergajian bisa dimanfaatkan untuk kayu bakar atau arang.

\section{b. Penebasan semak}

Penebasan semak berkayu dan tumbuhan bawah bisa dilakukan menggunakan parang dan mesin pemotong rumput. Penebasan menggunakan parang dapat menghindari pemotongan jenis asli (native species) yang diperlukan untuk percepatan rehabilitasi atau restorasi lahan.

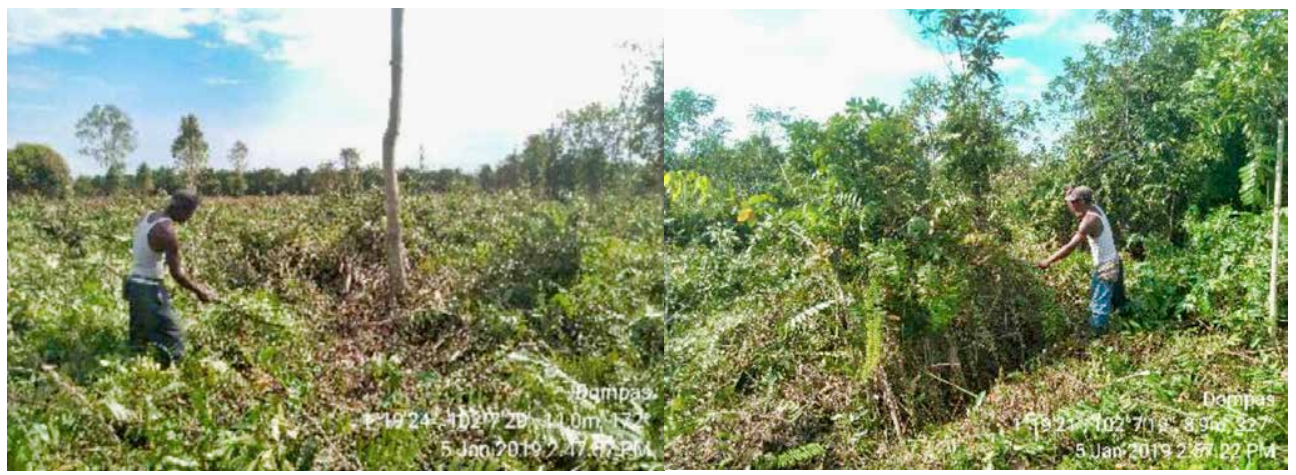

Gambar 5.4 Penebasan semak dan tumbuhan herba 


\section{Kotak 5.3 Vegetasi berkayu di lahan gambut setelah kejadian} kebakaran

Beberapa jenis pohon asli yang tumbuh di lahan gambut pesisir yang telah terbakar di Desa Dompas adalah leban (Vitex pubescens), kelat (Syzygium sp.), ara (Ficus sp.), geronggang (Cratoxylon arborescens), dan mensira (Ilex sp.). Vegetasi semak berkayu yang tumbuh dominan adalah tenggek burung (Euodia redleyi) dan gelam (Melaleuca leucadendron). Pada saat penyiapan lahan, khususnya ketika dilakukan penebasan semak, jenis-jenis pohon dan semak berkayu ini perlu dipertahankan untuk percepatan restorasi gambut.

\section{c. Penumpukan biomassa}

Penumpukan (stacking) biomassa sisa vegetasi hasil tebangan dan tebasan pada jalur sampah (jalur kotor) bertujuan untuk menyiapkan lorong yang bersih dan rata, sehingga mempermudah penanaman dan pemeliharaan tanaman. Sebagai contoh, untuk penanaman nanas (kultivar Mores), perlu dipersiapkan lorong selebar $25 \mathrm{~m}$. Penumpukkan sisa vegetasi yang berat sering dilakukan dengan bantuan alat berat. Namun, penggunaan alat berat berisiko menyebabkan penurunan permukaan lahan gambut sehingga berpotensi membuat bidang lahan budidaya mudah tergenang/ banjir, mengingat permukaannya menjadi lebih rendah dari sekelilingnya.

Sisa vegetasi kecil yang tidak bisa dimanfaatkan, seperti ranting, daun, batang, dan kulit kayu bisa ditinggalkan di areal penanaman. Limbah biomassa tersebut dapat dicincang secara manual, kemudian disebarkan secara merata di lokasi penanaman. Penyebaran limbah ini berfungsi sebagai mulsa bagi tanah, yang melengkapi peranan sisa perakaran pakis dan paku-pakuan, yang dikenal oleh masyarakat Riau sebagai akar ghambut. Mulsa dan akar ghambut ini akan terurai dengan sendirinya dan mengembalikan unsur-unsur hara yang dikandungnya ke tanah. Mulsa dan akar ghambut juga bermanfaat untuk menghambat pertumbuhan gulma, menjaga kelembaban tanah, suhu tanah, dan kehidupan mikroorganisme, sehingga tercipta kondisi lahan yang sesuai untuk pertumbuhan tanaman. Di lahan mineral, mulsa juga mampu mengurangi pukulan air hujan ke permukaan tanah sehingga dapat mengurangi erosi tanah dan memperbesar peluang resapan air ke dalam tanah. Keberadaan mulsa dan akar ghambut ini akan hilang jika penyiapan lahan dilakukan dengan menggunakan alat berat, karena akar ghambut akan dikupas dan ditumpuk di jalur kotor atau disingkirkan di pinggir lahan. 
Kotak 5.4 Pentingnya "akar ghambut" untuk melindungi "tanah ghedang"

Petani Dusun Kampung Jawa (Kelurahan Sungai Pakning, Kecamatan Bukit Batu, Bengkalis) sudah melakukan penanaman nanas Mores di lahan gambut. Berdasarkan pengalaman petani nanas di Kampung Jawa, penggunaan alat berat untuk mengupas (scrapping) lapisan sisa perakaran vegetasi pakis dan paku-pakuan setebal sekitar $10 \mathrm{~cm}$ ternyata menyebabkan kelembaban gambut mengalami penurunan yang signifikan. Oleh karenanya, mereka menyarankan agar keberadaan lapisan sisa perakaran ini dipertahankan sebagai penjaga kelembaban tanah. Masyarakat lokal menyebut lapisan ini sebagai "akar ghambut" yang penting untuk melindungi "tanah ghedang" atau lapisan gambut di bawahnya.

Nanas Mores dikenal cukup adaptif dan dapat tumbuh baik pada lahan gambut yang asam dan miskin hara. Menurut pengalaman petani di Desa Tanjung Layang (Kecamatan Sungai Apit, Kabupaten Siak) dan Kelurahan Sei Pakning, budidaya nanas Mores tidak memerlukan pupuk dasar maupun kapur (dolomit) sebagai upaya memperbaiki kualitas gambut sebagai media pertumbuhan. Meskipun demikian, apabila dianggap perlu, pemupukan cukup dilakukan pada bulan ketiga dan keenam, yaitu dengan memberikan tambahan unsur nitrogen $(\mathrm{N})$.
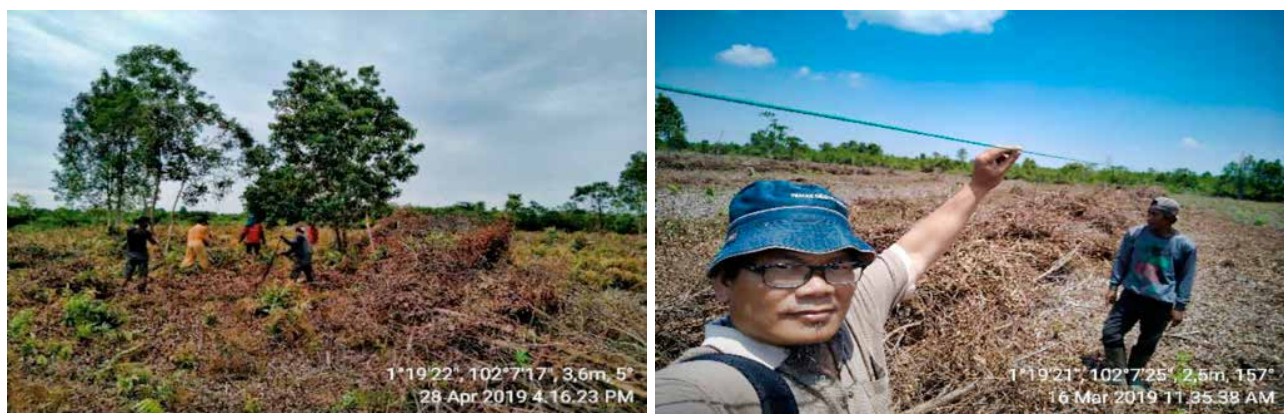

\section{Gambar 5.5 Penumpukan biomassa pada jalur-jalur kotor}




\section{d. Pengendalian gulma}

Pengendalian gulma bisa dilakukan dengan penyemprotan herbisida sebelum dilakukan penanaman. Gulma biasanya akan tumbuh merata kembali 15-21 hari setelah penebasan vegetasi. Kecepatan pertumbuhan gulma dipengaruhi oleh intensitas curah hujan. Beberapa jenis gulma di lahan gambut adalah paku-pakuan, rumput-rumputan, dan perdu berdaun lebar. Penyemprotan herbisida dapat dilakukan setelah tunastunas tumbuhan herba tumbuh kembali secara merata, sehingga pengaruh aplikasi herbisida lebih efektif pada gulma. Pemberantasan gulma dapat dilakukan secara berulang untuk meningkatkan persen kematian gulma. Namun hal itu perlu dilakukan dengan mempertimbangkan dampak penggunaan bahan kimia terhadap lingkungan, dan efek penggunaan herbisida yang dapat mendorong munculnya emisi gas metan $\left(\mathrm{CH}_{4}\right)$ dari bahan organik yang membusuk secara anaerob.

\section{Kotak 5.5 Pertumbuhan herba di musim kemarau pertama}

Musim kemarau di Riau terjadi dua kali setahun. Musim kemarau pertama terjadi pada bulan Februari - Maret, ditandai dengan curah hujan yang rendah, sehingga banyak terjadi kebakaran lahan dan hutan, khususnya di lahan gambut. Kondisi ini berpengaruh pada pelambatan pertumbuhan tunas muda herba, sehingga jadwal penyemprotan herbisida pertama dan ulangan yang kedua di Desa Dompas mengalami kemunduran. Penyemprotan herbisida pertama baru dapat dilakukan 1,5 bulan setelah penebasan atau pada minggu kedua Februari 2019. Penyemprotan herbisida yang kedua baru dapat dilakukan pada minggu ketiga Maret 2019. Vegetasi herba di lokasi ini didominasi oleh paku-pakuan, khususnya dari jenis pakis uban (Pteridium aquilinum), paku cebuk (Nephrolepis bisserata), paku miding (Stenochlaena palustris), paku hijau (Blechnum indicum), dan akar kait-kait (Uncaria acida).

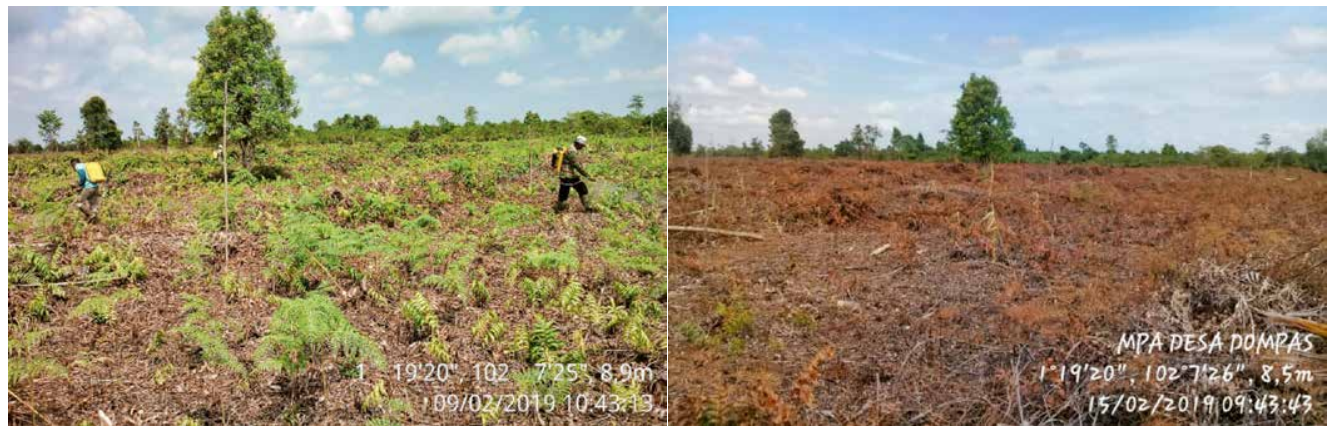

\section{Gambar 5.6 Penyemprotan herbisida pertama (1,5 bulan setelah penebasan) dan kondisi lahan setelah dilakukan aplikasi herbisida}

Sumber: foto oleh Masyarakat Peduli Api (MPA) Desa Dompas 


\section{e. Pembersihan tunggul}

Tunggul bisa dilapukkan dengan menggunakan jamur pelapuk, seperti Trametes sp. untuk tunggul kayu keras dan Pleurotus sp. untuk tunggul kayu lunak. Tunggul juga bisa digali/dicabut dengan menggunakan linggis dan chainsaw. Pembersihan tunggul dimaksudkan untuk mengurangi munculnya terubusan yang mengganggu tanaman budidaya dan menciptakan kenyamanan bekerja dalam pemeliharaan tanaman semusim. Penghancuran/pencabutan tunggul juga berguna untuk memperluas daerah perakaran bagi tanaman budidaya sehingga akan menghasilkan pertumbuhan yang baik bagi bibit tanaman semusim. Kegiatan pembersihan tunggul ini tidak diperlukan jika tujuan penyiapan lahan adalah untuk budidaya tanaman tahunan yang tidak membutuhkan pemeliharaan intensif.
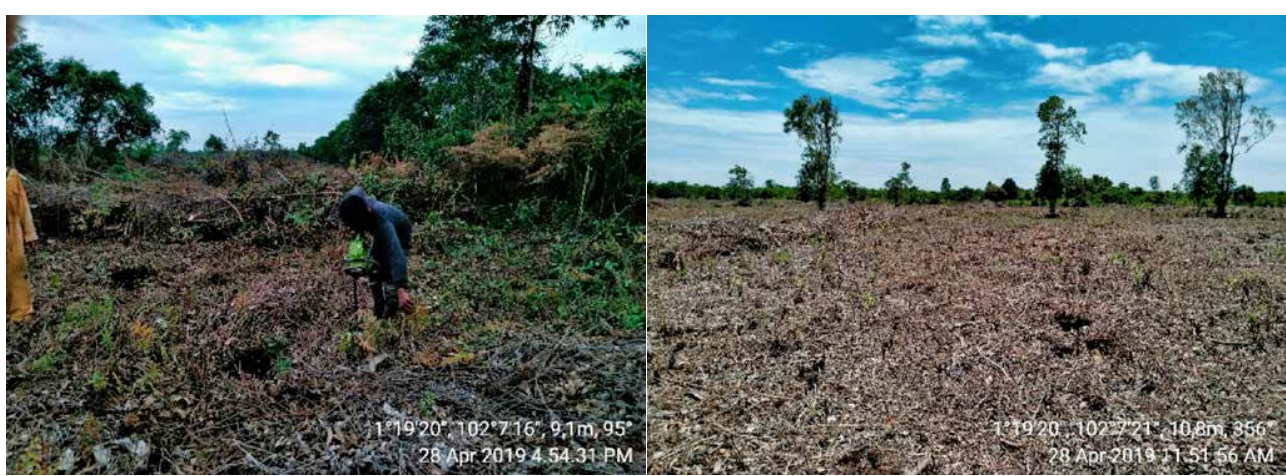

Gambar 5.7 Pembersihan tunggul menggunakan chainsaw dan kondisi lorong tanaman yang siap untuk ditanam

\section{f. Pembuatan perigi}

Masyarakat Melayu Riau mempunyai kearifan lokal yang dapat diberdayakan untuk mengantisipasi kebakaran lahan yang baru dibuka. Mereka biasa membuat perigi di sekeliling batas lahan. Yang dimaksud dengan perigi adalah sumur dangkal berbentuk petak dengan kedalaman $200 \mathrm{~cm}$, lebar $100 \mathrm{~cm}$, dan panjang $200 \mathrm{~cm}$. Ukuran perigi bisa dimodifikasi sesuai dengan kondisi lahan, tinggi muka air, dan manfaat tambahan yang diharapkan. Selain untuk penanda batas kepemilikan lahan, pembuatan perigi juga bermanfaat untuk mempermudah akses air di lahan gambut yang dapat dimanfaatkan untuk berbagai keperluan, termasuk dalam pemadaman api, serta sebagai titik pemantauan kedalaman muka air tanah yang efisien. 


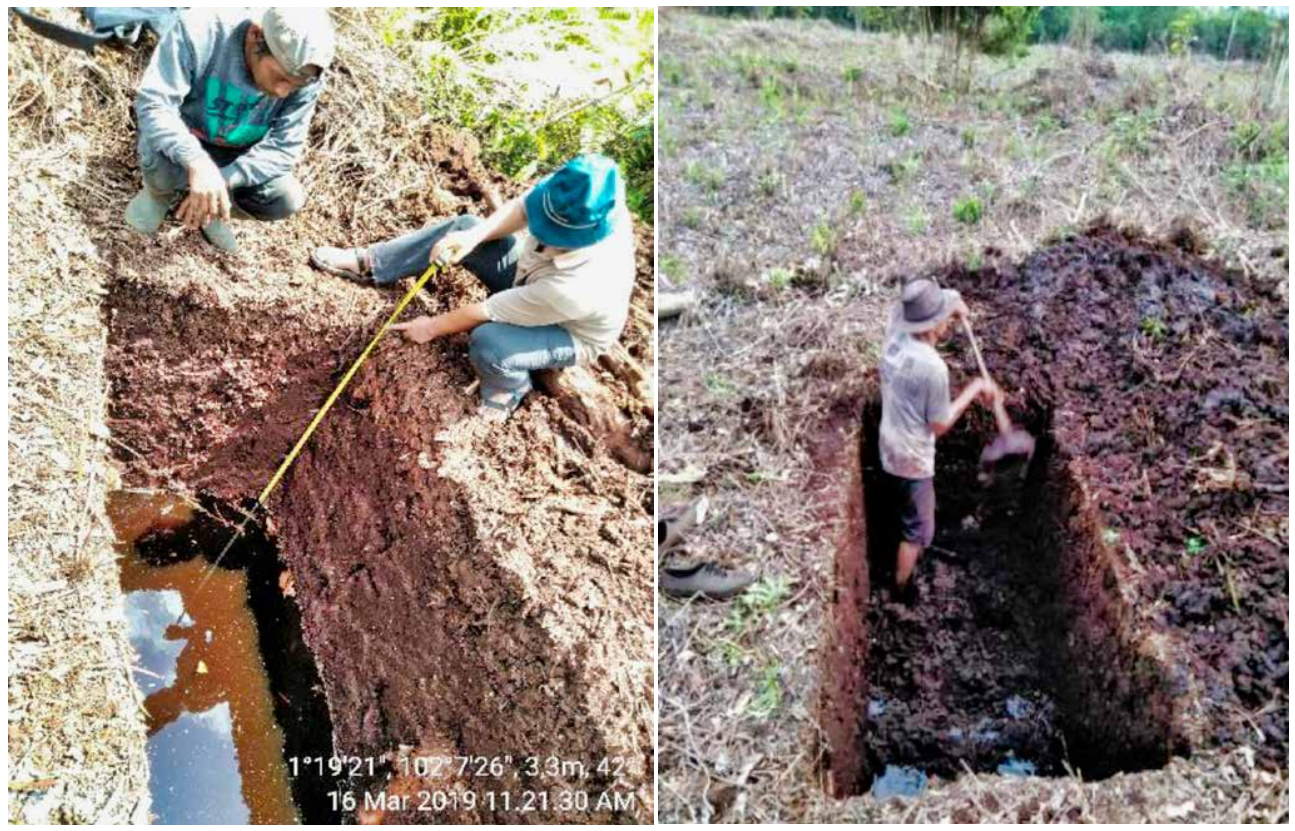

Gambar 5.8 Penggalian perigi secara manual menggunakan cangkul dan pemanfaatannya untuk pemantauan kedalaman muka air tanah di lahan gambut

\subsection{PERBANDINGAN BIAYA DARI BEBERAPA METODE PENYIAPAN LAHAN}

Kegiatan PLTB memang membutuhkan biaya yang lebih mahal (Tabel 5.3). Penyiapan lahan secara manual untuk budidaya tanaman nanas di Desa Dompas diperlukan biaya sebesar Rp 6.300.000,00/ha. Biaya ini diperkirakan akan turun jika tanaman yang dibudidayakan berupa karet, kelapa sawit, atau tanaman perkebunan sejenis yang tidak memerlukan penyiapan lahan intensif. Meskipun lebih mahal, PLTB dalam jangka panjang akan memberikan banyak keuntungan, seperti lebih tingginya nilai unsur hara yang tersedia di lahan, adanya limbah kayu atau limbah lainnya yang dapat dimanfaatkan sehingga memberikan nilai tambah. Selain itu PLTB juga bersifat lebih ramah terhadap lingkungan, tidak menimbulkan asap, dan tidak mengganggu kegiatan sosial dan ekonomi (kesehatan dan transportasi). 
Tabel 5.3 Perbandingan biaya dari beberapa metode penyiapan lahan

\begin{tabular}{lccc}
\hline \multirow{2}{*}{$\begin{array}{c}\text { Jenis Biaya } \\
\text { (dalam Rupiah) }\end{array}$} & Pembakaran & Mekanis Berat & $\begin{array}{c}\text { Tebang Manual untuk } \\
\text { Kebun Nanas }\end{array}$ \\
\cline { 2 - 4 } & - & - & 250.000 \\
\hline Peralatan* & - & - & 100.000 \\
\hline Bahan bakar** & - & - & 700.000 \\
\hline Bahan kimia** & - & - & 4.750 .000 \\
\hline Tenaga kerja & - & - & 500.000 \\
\hline Pengawasan & 1.000 .000 & 7.000 .000 & 6.300 .000 \\
\hline Biaya Total (Rp/ha) & $2-5$ & $1-3$ & $30-40$ \\
\hline Waktu Total (HOK/ha) & & & \\
\hline
\end{tabular}

*) Peralatan: parang, alat semprot, dan linggis.

${ }^{* *}$ ) Bahan bakar untuk operasional chainsaw dalam penggalian tunggul.

$\left.{ }^{* * *}\right)$ Herbisida untuk pengendalian gulma.

\subsection{PUSTAKA}

Anshari G, Rossy M, Nuriman. 2010. Pengujian Dampak Penyiapan Lahan Gambut dengan Metode Pembakaran Terkendali Terhadap Perubahan Beberapa Sifat Fisik dan Kimia dan Besarnya Emisi Karbon. Pontianak, Indonesia: Universitas Tanjungpura.

Hendromono, Wibowo A, Martono D, Santoso E, Djarwanto, Prahasto H, Sallata MK, Rufi'ie, Suharyanto, Siran SA, dan Heriansyah I. 2007. Penyiapan Lahan Tanpa Bakar untuk Penanaman. Bogor, Indonesia: Departemen Kehutanan Badan Penelitian dan Pengembangan Kehutanan.

Hermawan W. 2006. Dampak Kebakaran Kebun dan Lahan terhadap Lingkungan Hidup. Pontianak, Indonesia: Dinas Perkebunan Provinsi Kalimantan Barat.

Noor M. 2010. Lahan Gambut: Pengembangan, Konservasi, dan Perubahan Iklim. Yogyakarta, Indonesia: Gadjah Mada University Press.

Nugroho PA. 2012. Penyiapan Lahan tanpa Bakar (Zero Burning) dalam Peremajaan Tanaman Karet di Perkebunan Komersial. Perkebunan dan Lahan Tropika, 2(2): 3950.

Subiksa IGM, Hartatik W, dan Agus F. 2011. Pengelolaan lahan gambut secara berkelanjutan. Bogor, Indonesia: Balai Penelitian Tanah dan Balai Besar Penelitian dan Pengembangan Sumberdaya Lahan Pertanian, Kementerian Pertanian. 
Sunanto. 2008. Peran Serta Masyarakat Dalam Pencegahan Dan Penanggulangan Kebakaran Lahan (Studi Kasus Kelompok Peduli Api Di Kecamatan Rasau Jaya Kabupaten Kubu Raya Provinsi Kalimantan Barat). [Tesis Master]. Semarang, Indonesia: Program Studi Ilmu Lingkungan Universitas Diponegoro.

Tjahjono I. 1999. Hutan Kita Dibakar. Jakarta, Indonesia: SKEPHI.

Yuliani F, Saktioto S, Rosnita R, Pailis EA, Murniati M, dan Tjarsono I. 2019. Sistem pengolahan lahan tanpa bakar dalam kebakaran hutan dan lahan pada kawasan gambut Kecamatan Bukit Batu Kabupaten Bengkalis. Unri Conference Series: Community Engagement, 1: 645-651.

Yulianti N dan Adji FF. 2018. Mari Belajar Tentang Pengelolaan Lahan Tanpa Bakar (PLTB). Bogor, Indonesia: IPB Press. 



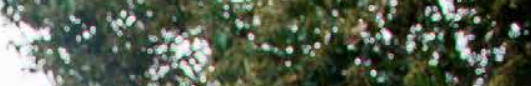

4. $\therefore$ is
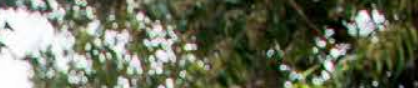

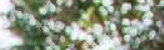
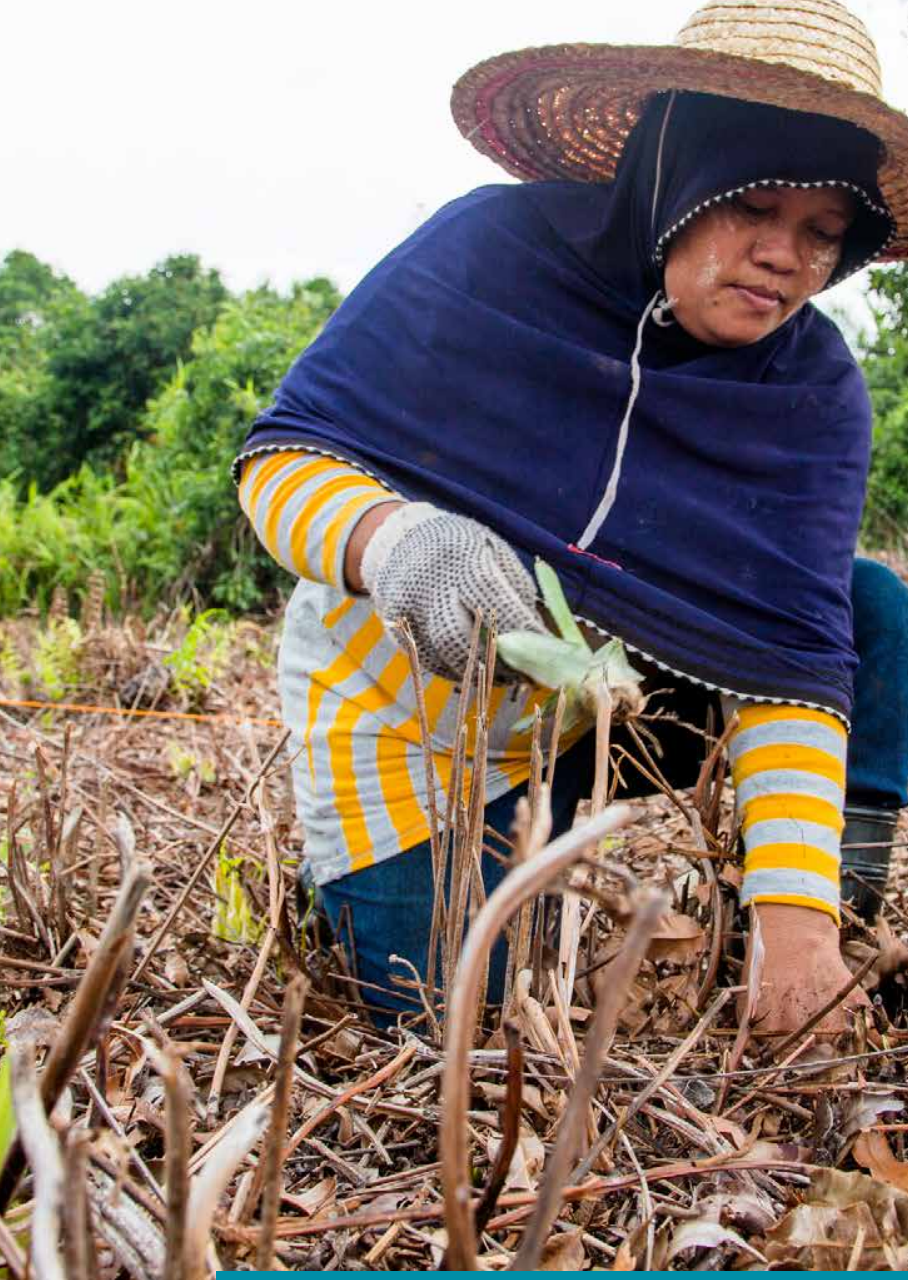

arestos?

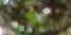

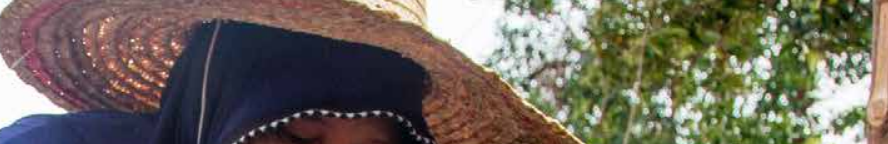
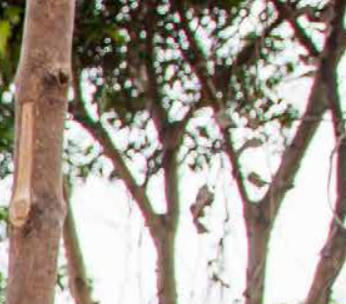
कित करती

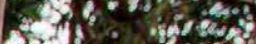

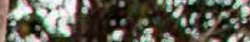
$3: 2,0,20$ an: 0120
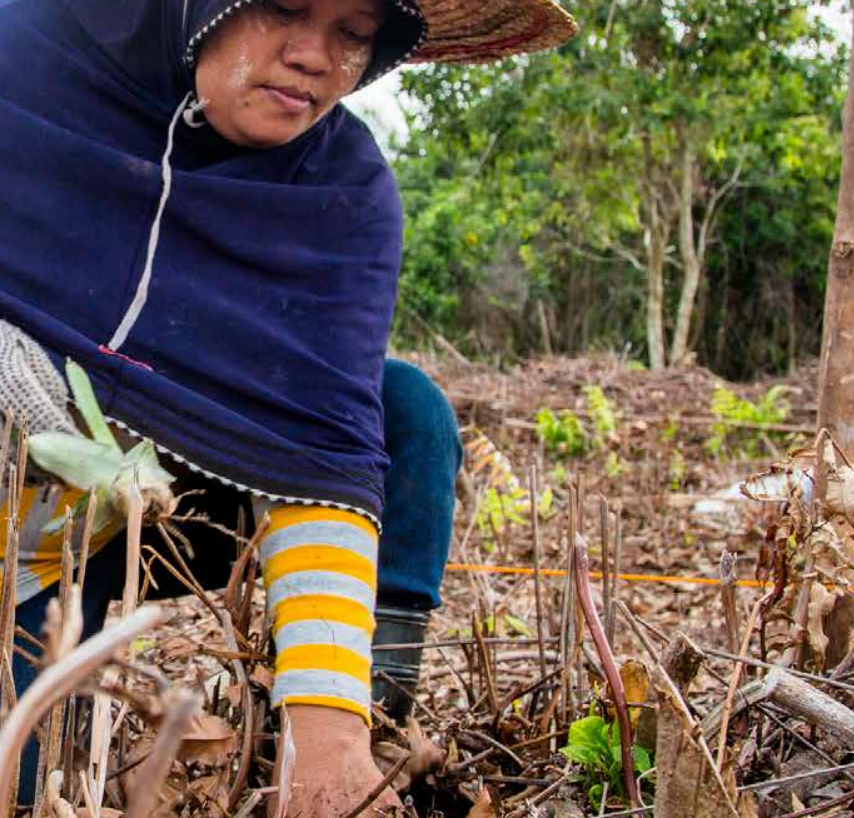

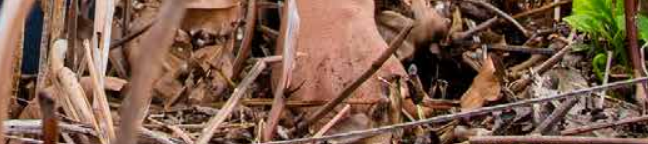

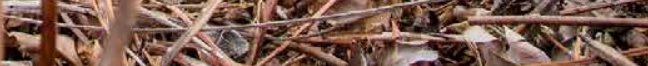

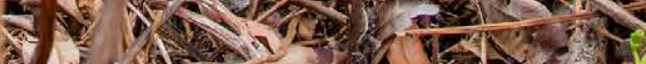

25 2.

Pembelajaran 6

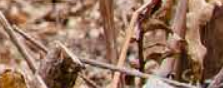
5. 10 (1)

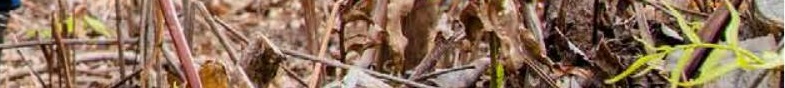

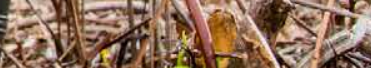

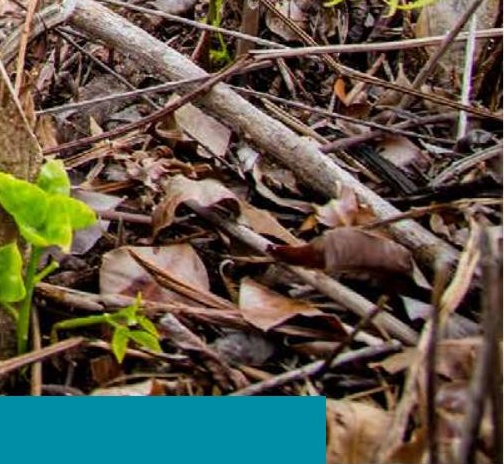

Penanaman di Lahan Gambut

Pandam Nugroho Prasetyo, Zulkardi, Rafi Merbamas, Herry Purnomo dan Dyah Puspitaloka 


\subsection{PEMULIHAN LAHAN GAMBUT}

Revegetasi merupakan salah satu pendekatan dalam pemulihan lahan gambut. Melalui Peraturan Menteri Lingkungan Hidup dan Kehutanan Republik Indonesia Nomor P.16/ MENLHK/SETJEN/KUM.1/2/2017 Pemerintah Indonesia memberikan pedoman teknis untuk pemulihan fungsi ekosistem gambut. Pada peraturan ini disebutkan beberapa jenis tanaman, baik berdasarkan kondisi lokasi maupun berdasarkan kelompok manfaatnya. Termasuk dalam jenis-jenis tanaman tersebut adalah tanaman kayu, seperti meranti rawa (Shorea pauciflora, Shorea tesmanniana, Shorea uliginosa), ramin (Gonystylus bancanus), dan gaharu (Aquilaria sp.) maupun tanaman penghasil pangan, termasuk pohon buah, misalnya mangga kasturi (Mangifera casturi) dan sagu (Metroxylon spp.).

Riset Aksi Partisipatif (RAP) untuk pencegahan kebakaran dan restorasi gambut diterapkan melalui uji coba lapangan yang difokuskan di Desa Dompas, Kecamatan Bukit Batu, Kabupaten Bengkalis, Provinsi Riau. Hasil uji coba ini kemudian disebarluaskan di desa-desa satelit lainnya. Sebagian besar wilayah Desa Dompas merupakan kawasan ekosistem gambut, yang didefinisikan oleh Kementerian Lingkungan Hidup dan Kehutanan (2017) sebagai tatanan unsur gambut yang merupakan satu kesatuan utuh menyeluruh yang saling mempengaruhi dalam membentuk keseimbangan, stabilitas, dan produktivitasnya. Untuk mengimplementasikan 3R (Revegetation, Rewetting dan Revitalization), CIFOR dan PSB UNRI memfasilitasi uji coba pada tujuh arena aksi yang berada di Desa Dompas. Arena aksi ini berada pada lahan gambut yang sudah mengalami pengeringan dan rawan kebakaran. Pendekatan 3R dalam rangka pemulihan fungsi ekosistem gambut difokuskan pada upaya mengembalikan sifat dan fungsi ekosistem gambut sesuai atau mendekati sifat dan fungsi semula.

\subsubsection{Tahapan penanaman kembali}

tahapan proses penanaman kembali yang dilakukan pada arena aksi ditunjukkan pada Gambar 6.1. Pada fase refleksi, dilakukan kajian data dasar, literatur dan biofisik. Selanjutnya, pada fase perencanaan dilakukan rangkaian diskusi kelompok terarah (Focus Group Discussion/FGD) untuk pemilihan jenis tanaman. Berdasarkan hasil FGD, beberapa jenis tanaman kayu prioritas yang dipilih masyarakat adalah: meranti, gaharu, durian, kopi dan manggis. Beberapa dari tanaman yang dipilih oleh masyarakat tersebut sudah sesuai dengan P.16/MENLHK/SETJEN/KUM.1/2/2017 dan disesuaikan dengan keadaan biofisik di Desa Dompas. Selain pemilihan jenis tanaman, penyusunan model bisnis untuk masing-masing komoditas tersebut juga dilakukan melalui proses FGD, yang dibahas pada bab terpisah di buku ini. 

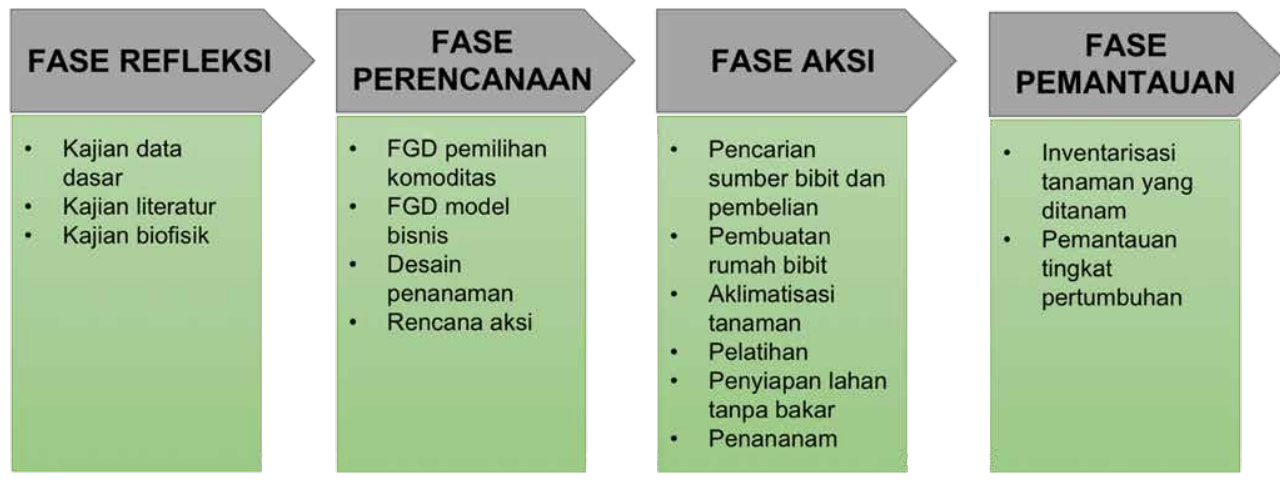

\section{Gambar 6.1 Tahapan penanaman kembali dalam konteks RAP}

\subsubsection{Pembangunan Rumah Pembibitan Dompas secara partisipatif dan proses aklimatisasi}

Rumah pembibitan merupakan bagian yang penting dalam proses kegiatan revegetasi lahan gambut. Sebagian besar program rehabilitasi gagal karena tidak adanya aklimatisasi pohon. Untuk mencegah hal tersebut, maka pada proses RAP dibangun rumah pembibitan Dompas dengan fungsi utama untuk menampung bibit pohon dan aklimatisasi sebelum proses penanaman dilakukan. Proses aklimatisasi, menurut Puslitbang Hortikultura Kementerian Pertanian, merupakan suatu proses yang penting sebagai "upaya penyesuaian kondisi lingkungan secara bertahap dikondisikan supaya iklim mikro di sekitar tanaman optimal dan tidak membuat tanaman stres”.

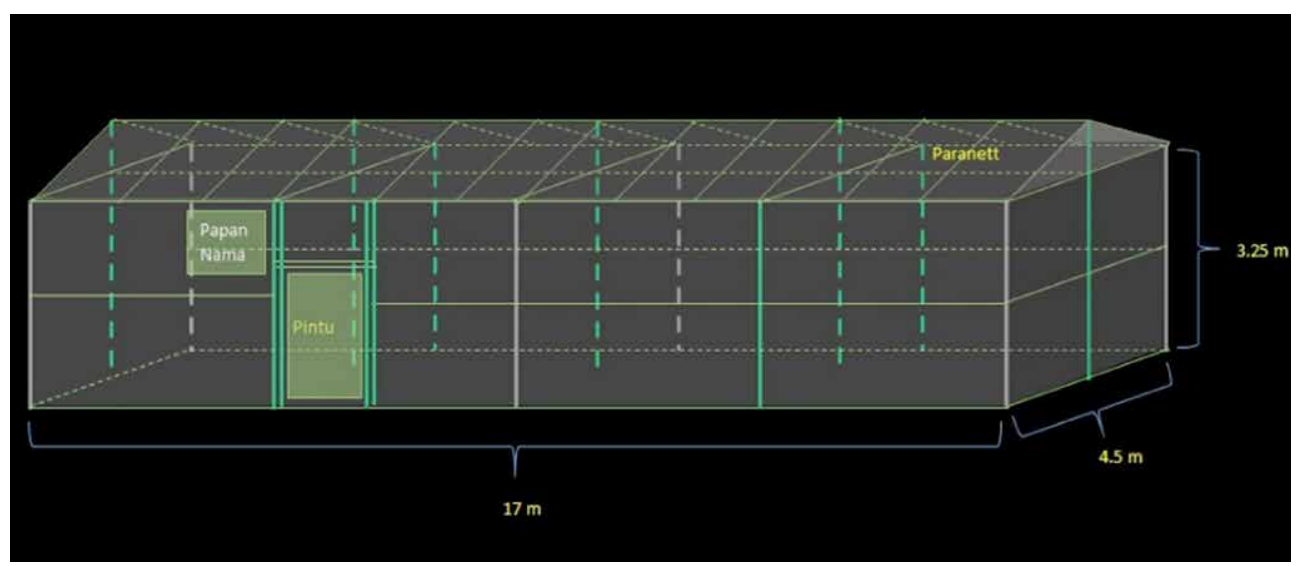

Gambar 6.2 Desain rumah bibit 
Dimensi rumah pembibitan Dompas adalah $17 \times 4,5 \times 4 \mathrm{~m}^{3}$. Selain sebagai tempat menampung bibit untuk kegiatan restorasi, rumah pembibitan dompas juga dimanfaatkan oleh kelompok tani wanita untuk melakukan pembibitan berskala rumah tangga untuk beberapa tanaman hortikultura, termasuk cabe dan semangka (Gambar 6.2).

Untuk menyelesaikan pembangunan rumah pembibitan dibutuhkan waktu sembilan hari dengan tenaga kerja sekitar 4-5 orang. Proses pembangunan rumah pembibitan Dompas dilakukan secara partisipatif, mulai dari pembagian tugas, pembuatan desain dan persiapan material (Kotak 6.1).

Secara umum kegiatan pembangunan rumah pembibitan berperan untuk:

1. Memperkuat modal sumber daya manusia dan sosial, yaitu sebagai tempat untuk membuat pembibitan, bertukar informasi, pengetahuan, pengalaman dan belajar untuk anggota MPA, kelompok tani dan masyarakat desa.

2. Memperkuat modal finansial/ekonomi, yaitu dapat dijadikan modal untuk bisnis pembibitan dan penghasilan tambahan dalam jangka panjang.

\section{Kotak 6.1 Material dan desain}

Material yang digunakan untuk membangun rumah pembibitan Dompas memanfaatkan bahan yang ada di sekitar desa dan di desa sekitarnya. Untuk tiang pancang digunakan kayu nibung (Oncosperma tigillarium) yang dikombinasikan dengan paralon cor semen dengan diameter 5 inci. Menurut masyarakat, kayu nibung sangat terkenal dengan kekuatannya, yang bersifat tahan lapuk dan biasanya digunakan sebagai penyangga rumah di tepi sungai atau di atas rawa gambut. Untuk bagian rangka digunakan bambu dengan diameter 3 inci. Bambu digunakan karena memiliki elastisitas yang cukup tinggi dan sanggup menahan beban tekuk dan tarik yang kuat. Bambu juga memiliki bobot yang sangat ringan sehingga tidak membebani beban bangunan secara keseluruhan. Secara ekologis, bambu dipilih karena lebih ramah lingkungan dan merupakan tanaman yang memiliki laju pertumbuhan cepat dan mudah tumbuh kembali setelah ditebang, berbeda dengan pemanfaatan kayu yang membutuhkan waktu yang lama untuk dapat dipanen kembali setelah ditebang. Selain itu, bambu dipilih karena kelimpahannya yang cukup banyak di sekitar Desa Dompas dan harga yang relatif lebih murah, jika dibandingkan dengan kayu. Jumlah bambu dan kayu nibung yang digunakan untuk pembangunan rumah pembibitan Dompas dapat dilihat pada Tabel 6.1 
Kotak 6.1 sambungan

Tabel 6.1 Jumlah kayu dan bambu yang dibutuhkan untuk pembuatan rumah pembibitan.

\begin{tabular}{clccc}
\hline No & Jenis & Ukuran $(\mathbf{m})$ & Diameter (inci) & Jumlah \\
\hline 1 & Nibung & 5 & 5 & 12 batang \\
\hline 2 & Bambu & $3-4$ & 3 & 24 batang \\
\hline 3 & Paranet & $0,12-0,5$ & - & 2 gulung \\
\hline 4 & Paralon & - & 0,5 & 3 batang \\
\hline 5 & Semen & - & - & 5 sak \\
\hline 6 & Pasir & - & - & 1 kubik \\
\hline 7 & Kerikil & - & - & 1 kubik \\
\hline 8 & Paku & - & - & 5 kg \\
\hline 9 & Keran air & - & - & 2 buah \\
\hline 10 & Selang & $10 \mathrm{~m}$ & - & 1 buah \\
\hline
\end{tabular}

Untuk mengurangi sinar matahari yang masuk ke rumah pembibitan dan untuk mencegah tanaman stres karena terkena sinar matahari langsung, maka paranet dipasang pada dinding dan atap dengan tingkat kerapatan anyaman 25\%-40\%, yaitu paranet jenis 60\%-75\%. Paranet tipe ini biasa digunakan untuk rumah pembibitan tanaman kayu dan beberapa jenis hortikultura. Paranet tersebut, mampu menahan cahaya 60\%-75\% sehingga cahaya yang diterima bibit adalah sekitar 25\%-40\% saja. ${ }^{8}$ Paranet terbuat dari bahan plastik polietilen yang kemudian dianyam sesuai kebutuhan. Kebutuhan paranet untuk menaungi area rumah pembibitan dompas yaitu sebanyak dua gulung, dengan lebar $120 \mathrm{~cm}$ dan panjang $50 \mathrm{~m}$ tiap gulungan. Selain material yang sudah disebutkan sebelumnya, beberapa material lain yang dibutuhkan untuk membuat rumah pembibitan, yaitu: paralon 1/2 inci (3 batang), semen ( 5 sak), pasir (1 kubik), kerikil (1 kubik), paku (5 kg), keran air (2 buah), dan selang (10 meter). 


\subsubsection{Kegiatan revegetasi pada arena aksi Desa Dompas}

Revegetasi adalah upaya pemulihan tutupan lahan pada ekosistem gambut melalui penanaman jenis tanaman asli pada fungsi lindung atau dengan jenis tanaman lain yang adaptif terhadap lahan basah dan memiliki nilai ekonomi pada fungsi budidaya. Terdapat beberapa cara melakukan revegetasi, menurut BRG, yaitu melalui penanaman benih endemis dan adaptif dan juga pengayaan penanaman (enrichment planting). Di samping itu, dapat juga dilakukan peningkatan dan penerapan teknik agen penyebar benih (seed dispersal techniques).

Kegiatan revegetasi di Desa Dompas dilakukan secara partisipatif bersama masyarakat pengelola arena aksi. Jenis-jenis pohon hasil verifikasi yang sudah diuji coba untuk ditanam dan berhasil hidup, antara lain: meranti, gaharu, geronggang, manggis, durian, cempedak, matoa dan kopi. Berdasarkan pengetahuan masyarakat lokal, beberapa hal yang menjadi catatan pada saat kegiatan penanaman secara partisipatif di Desa Dompas, adalah:

1. Pastikan jenis pohon yang dipilih pernah tumbuh di desa tersebut dan bisa dimanfaatkan oleh masyarakat.

2. Sebaiknya bibit yang ditanam memiliki tinggi minimal $70 \mathrm{~cm}$, dalam keadaan sehat (tidak ada daun yang layu) dan sudah melalui proses aklimatisasi iklim setempat.

3. Disarankan melakukan kegiatan penanaman pada musim hujan. Jika penanaman terpaksa dilakukan pada musim kemarau, sebaiknya bibit ditanam pada area teduh yang terdapat naungan dan penyiraman dilakukan secara intensif. Sebagai alternatif, pakis atau semak dapat dibiarkan menjadi naungan jika penanaman dilakukan pada musim kemarau, yaitu dengan membuat piringan berdiameter 50$100 \mathrm{~cm}$ di sekitar lubang tanam.

4. Jika penanaman dilakukan pada musim kemarau, sebelum mulai menanam harus dipastikan bahwa pada saat digali, tanah berada dalam kondisi lembab secara alami.

5. Perlu dilakukan pengamatan secara intensif pada bibit yang sudah ditanam, yaitu dengan melakukan penyiraman dan pembersihan semak atau pakis yang tidak dibutuhkan, untuk memastikan bibit yang ditanam dapat tumbuh dengan optimal.

\subsubsection{Tahapan penanaman dan perawatan berdasarkan pembelajaran di Desa Dompas}

Tahapan penanaman pada lahan gambut bekas terbakar adalah sebagai berikut:

1. Pembuatan lubang penanaman dengan ukuran $(25 \mathrm{~cm} \times 25 \mathrm{~cm})$ dan kedalaman $50 \mathrm{~cm}$ di dalam tanah yang telah ditentukan.

2. Pemberian pupuk kompos atau kandang yang ditambahkan dengan NPK, Urea dan $\mathrm{KCl}$ dalam lubang tanam dengan penyesuaian jarak antar pohon ( $3 \times 5,5 \times 5,5 \times 10 \mathrm{~m})$. 
3. Penyulaman dilakukan pada 1-4 bulan pertama setelah proses penanaman.

4. Pemberian pupuk idealnya setiap dua bulan sekali sampai satu tahun dengan komposisi pupuk organik 80\% (kompos atau kandang) dan pupuk kimia 20\% (NPK, Urea dan $\mathrm{KCl}$ ). Pada tahun kedua pemberian pupuk dilakukan setiap empat bulan sekali, dan pada tahun ketiga pemberian pupuk dilakukan setiap enam bulan sekali.

\subsubsection{Pemantauan kegiatan revegetasi pada arena aksi Desa Dompas}

Untuk memastikan keberhasilan kegiatan penanaman (revegetasi), diperlukan pemantauan terhadap setiap individu yang ditanam. Dalam kegiatan ini, CIFOR membangun sistem informasi pemantauan digital untuk mengetahui perkembangan pohon tersebut dan memastikan secara real time jumlah pohon yang tertanam. Beberapa data yang diambil, antara lain adalah jenis pohon dan tinggi pohon. Tahapan pengambilan data yang dilakukan dalam pemantauan pohon, antara lain:

1. Memberikan tanda (tagging/marking) pohon yang sudah ditanam dengan menggunakan label dengan barcode yang sudah disiapkan.

2. Pemindaian barcode pohon yang sudah ditanam dengan menggunakan perangkat gawai berbasis Android.

3. Setelah data otomatis terekam, pastikan data sudah terekam secara akurat pada perangkat gawai berbasis Android, untuk kemudian segera dikirim ke server.

Kemajuan teknologi yang tepat guna serta mudah dipahami dan sejalan dengan konsep restorasi, sangat membantu mempercepat upaya pemulihan ekosistem gambut yang rusak. Penjelasan lebih rinci mengenai pemantauan tersedia pada bab lain dari buku ini.

\subsubsection{Pustaka}

Badan Restorasi Gambut. 2019. Revegetasi. [diakses 11 Agustus 2019]. https://brg.go.id/ program-kerja/?lang=en

Kementerian Lingkungan Hidup dan Kehutanan. 2017. Peraturan Menteri Lingkungan Hidup dan Kehutanan Republik Indonesia Nomor P.16/MENLHK/SETJEN/ KUM.1/2/2017 tentang Pedoman Teknis Pemulihan Fungsi Ekosistem Gambut.

Puslitbang Horti Kementerian Pertanian. Aklimatisasi tanaman mini (planlet) krisan yang berasal dari laboratorium. [diakses 1 Januari 2020]. http://balithi.litbang.pertanian. go.id/berita-442-.html 


\subsection{BUDIDAYA KOPI LIBERIKA DI LAHAN GAMBUT ${ }^{9}$}

\subsubsection{Kemampuan kopi liberika beradaptasi pada lahan gambut}

Kopi liberika (Coffea liberica) dikenal sebagai kopi khas gambut karena kemampuan untuk bisa beradaptasi dengan baik ditanah gambut sementara kopi jenis lain (arabika dan robusta) tidak bisa tumbuh (Hulupi 2014). Menurut Gusfarina (2014), kopi liberika juga toleran terhadap serangan hama dan penyakit serta tahan terhadap iklim yang panas dan kelembaban yang tinggi. Dalam hal perawatan, kopi liberika tidak memerlukan hortikultura intensif.

\subsubsection{Ciri khas kopi liberika}

Kopi ini memiliki ciri khas, yaitu daun tebal dan tajuk lebar, buah kopinya juga berukuran lebih besar dengan kulit yang juga lebih tebal jika dbandingkan dengan buah kopi arabika maupun robusta (Hulupi 2014). Menurut Nyoto ${ }^{10}$, karena ketebalan kulitnya, kopi liberika tidak bisa diproses secara manual dan tahan disimpan dalam jangka waktu yang lama. Jika sudah masak buah kopi akan berwarna merah, oranye kuning dan ada juga yang hijau kekuningan.

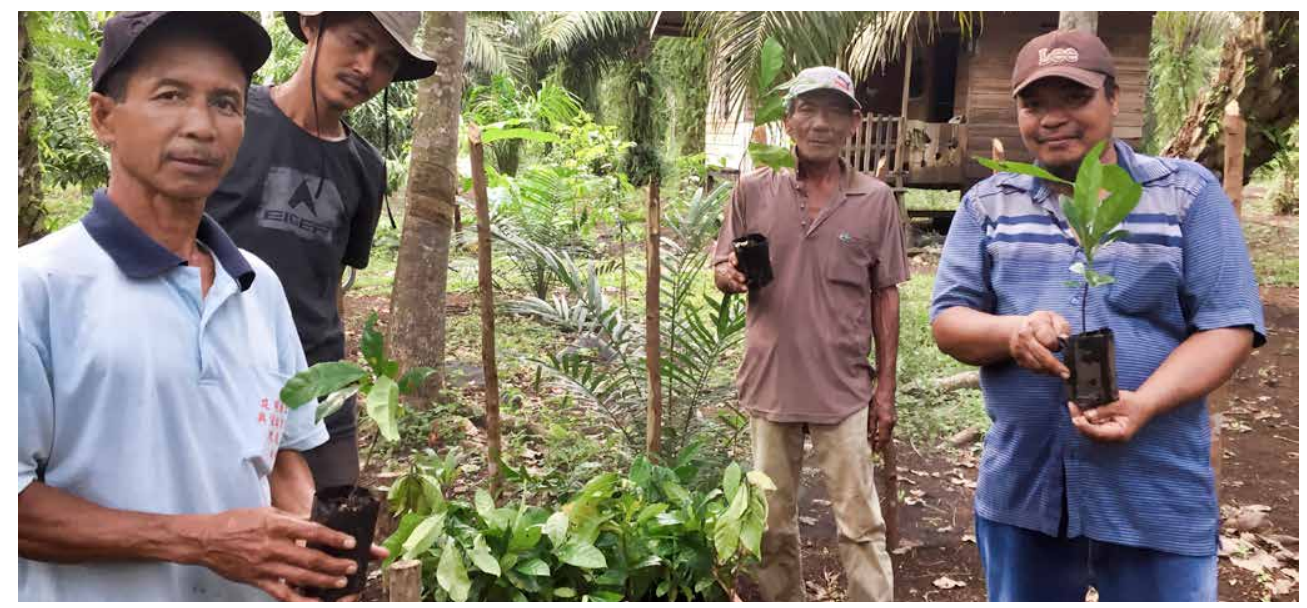

Gambar 6.3 Praktik Lapangan Pelatihan Kopi Liberika di Arena Aksi 4 (Kebun Bapak Atek), Desa Dompas, Kecamatan Bukit Batu, Bengkalis. (Foto oleh Pandam Nugroho Prasetyo/CIFOR)

9 Oleh: Pandam Nugroho Prasetyo, Rudi Hidayat, Nyoto dan Herry Purnomo

10 Komunikasi personal, 7 Mei 2019. 


\subsubsection{Sejarah kopi liberika}

Berdasarkan sejarahnya, kopi liberika masuk Indonesia pada abad ke-19 dibawa oleh Belanda menggantikan kopi arabika yang terserang hama daun karat atau Hemileia vastatrix (Hulupi 2014). Kopi liberika ditanam pada lahan basah atau gambut di sepanjang pantai timur Sumatera mulai dari Jambi sampai ke Kepulauan

Riau khususnya Kepulauan Meranti11.

Kopi liberika di tanah asalnya, biasa ditanam tumpang sari dengan tanaman lain kecuali dengan pohon kelapa sawit. Kopi liberika memerlukan naungan atau tanaman pelindung untuk mengurangi intensitas matahari sampai di kanopi daun. Kopi tidak bisa tumbuh baik pada areal terbuka. Tanaman kopi merupakan tanaman yang tidak rakus air dan tidak merusak tata kelola hidrologi gambut ${ }^{12}$.

\subsubsection{Kopi liberika di arena aksi}

Arena aksi 4, 5 dan 6 merupakan lahan gambut dengan konsep agroforestri atau wanatani karet. wanatani merupakan lahan dengan kombinasi antara tanaman keras dengan komoditas pertanian (de Foresta dkk. 2000). Adanya praktik Wanatani dapat dijadikan sebagai solusi untuk mengatasi permasalahan pemanasan global dan kemiskinan. Sebagian besar praktik wanatani dilakukan di lahan kering dan banyak bagian kecil di lahan basah baik lahan gambut maupun lahan pasang surut (Waluyo dan Nurlia 2017).

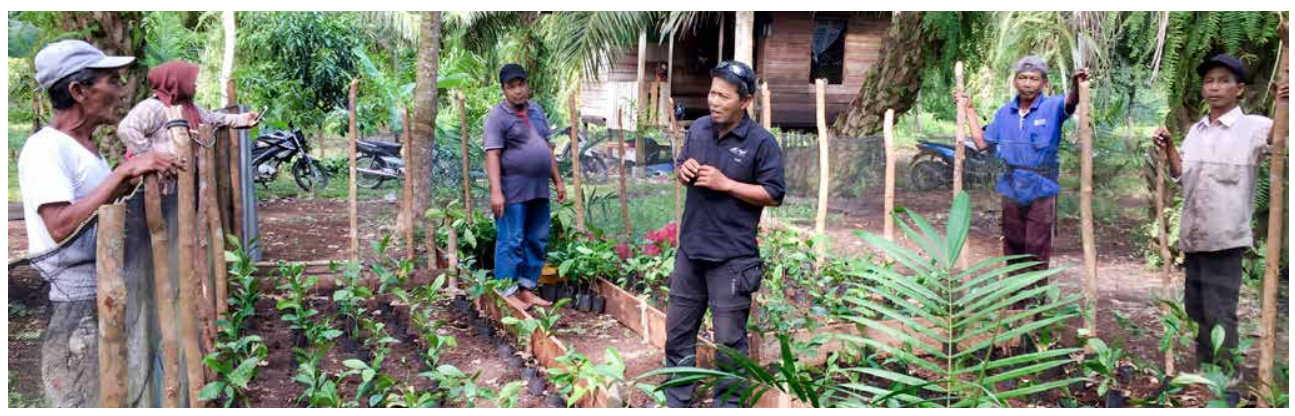

Gambar 6.4 Praktik Lapangan Pelatihan Kopi Liberika di Arena Aksi 4 (Kebun Bapak Atek), Desa Dompas, Kecamatan Bukit Batu, Bengkalis. (Foto oleh Pandam Nugroho Prasetyo/CIFOR)

\footnotetext{
11 Media Indonesia. 2018. Panen Kopi Liberika di Lahan Gambut. Diakses dari: https://mediaindonesia.com/read/detail/139631panen-kopi-liberika-di-lahan-gambut tanggal 7 Mei 2019

12 Yitno Suprapto. 2016. Kopi Aroma Unik Ini Bersahabat dengan Lahan Gambut. Diakses dari: https://www.mongabay. co.id/2016/11/24/kopi-aroma-unik-ini-bersahabat-dengan-lahan-gambut/ tanggal 7 Mei 2019
} 
Model yang berkembang tersebut salah satunya wanatani berbasis kopi. Model ini dapat memberikan manfaat baik secara sosial, ekonomi maupun secara ekologi (konservasi). Pohon pengisi pada wanatani berbasis kopi memberikan dampak baik secara ekonomi maupun ekologi pada tanaman kopi. Kopi yang ditanaman di bawah pohon pembayang yang jumlahnya diatur dapat memberikan hasil yang lebih tinggi (Lisnawati dkk. 2017).

\subsubsection{Potensi kopi liberika}

Kopi liberika merupakan salah satu komoditas unggulan di Kabupaten Kepulauan Meranti yang ditanam di antara pohon kelapa, pinang dan karet. Pada dasarnya kopi liberika memiliki potensi ekonomi yang tinggi sebab produk kopi liberika mulai disukai oleh konsumen karena cita rasanya (Ardiyani 2014). Karakter rasa kopi liberika tidak sepahit robusta ada aroma nangka asam mirip arabika dan coklat.

Menurut Nyoto, dalam satu batang pohon kopi liberika bisa menghasilkan lebih kurang sekitar 15-20 kg buah kopi. Jika sudah mulai berbuah, dalam kondisi ideal kopi liberika meranti bisa dipanen 20 hari sekali. ${ }^{13}$

Selanjutnya Nyoto menambahkan, di Kepulauan Meranti harga buah basah (ceri) untuk kopi berkisar Rp 2.500-4.000 per kg. Yang cukup bervariasi yaitu harga buah beras (biji kupas), yaitu di kisaran antara Rp 30.000-40.000 lebih tinggi daripada harga kopi robusta. Di Malaysia harga kopi liberika mencapai Rp 48.800-51.200 (Martono dkk. 2013). Ketika sudah green bean (biji kopi hijau kering), biji kopi liberika kualitas bagus bisa dijual dengan harga Rp 90.000-120.000 per kg dan akan meningkat menjadi Rp 200.000 per kg ketika sudah disangrai. Jika sudah dalam bentuk bubuk harganya meningkat lagi menjadi Rp 250.000-270.000 per kg. Untuk kopi liberika luwak harganya cukup fantastis, yaitu Rp 600.000 untuk yang sudah disangrai dan Rp 1.100.000-1.300.000 per kg untuk yang sudah bubuk. Peningkatan harga kopi dalam setiap proses biji sampai menjadi bubuk disebabkan karena adanya penyusutan berat, dari buah kopi (ceri) sampai menjadi green bean menyusut hingga 50-60\%. Dan setelah disangrai menyusut lagi sekitar 10-15\%.

Jadi, selain keunggulan dari aspek harga, kopi liberika juga memiliki hasil produksi lebih tinggi jika dibandingkan kopi robusta karena bisa berbuah sepanjang tahun dengan panen sekali sebulan (Gusfarina 2014). 


\section{Tahapan budidaya kopi liberika secara singkat}

\section{Pemilihan bibit}

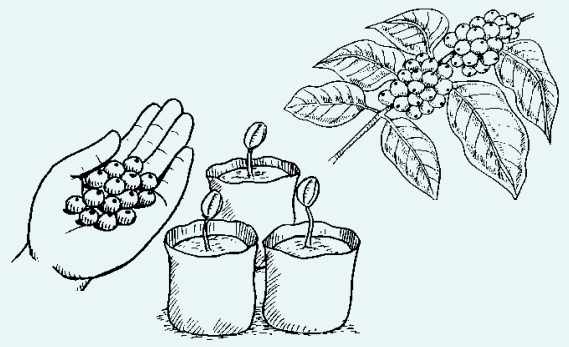

\section{Aklimatisasi}

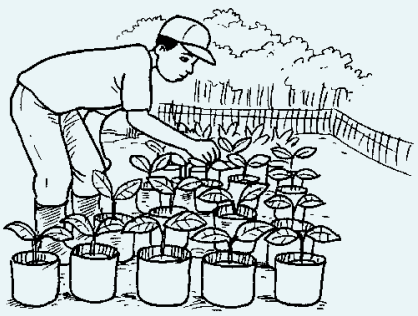

\section{Persiapan lahan}

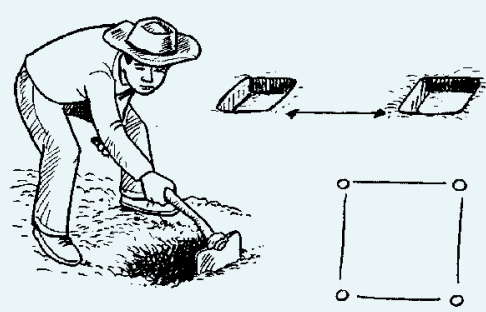

- Karena ditanam pada lahan gambut, bibit kopi liberika yang siap tanam, sebaiknya memiliki tinggi minimal $70 \mathrm{~cm}$ supaya tidak terlalu tenggelam ketika ditanam.

- Pastikan bibit kopi liberika berasal dari indukan yang tersertifikasi atau indukan yang berkualitas baik.

- Aklimatisasi bibit kopi liberika di pembibitan sekitar 4 minggu setelah bibit datang ke lokasi.

- Pembuatan jarak tanam ukuran $2,5 \times 2,5 \mathrm{~m}$ atau $3 \times 3 \mathrm{~m}$ tergantung dari posisi tanaman/ pohon naungan yang sudah ditanam

- Pembuatan lubang tanam dengan ukuran $\pm 40 \times 40 \mathrm{~cm}$. 


\section{Penanaman}

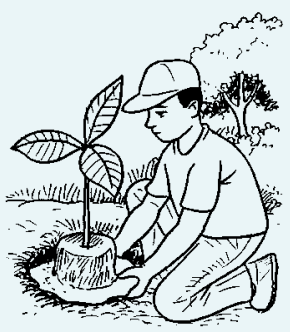

\section{Perawatan}
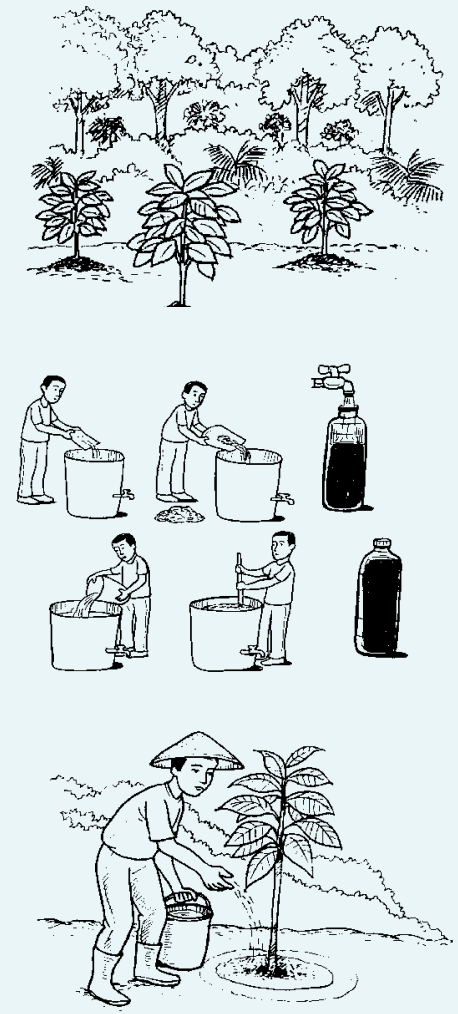

- Menanam bibit kopi liberika yang sudah melewati proses aklimatisasi

- Pastikan ada naungan disekitar bibit kopi yang ditanam.

- Pemupukan dilakukan selama 3-4 kali dalam setahun dengan menggunakan pupuk cair. Komposisinya yaitu: 30 kg (1 karung) kotoran sapi dicampurkan dengan $\mathrm{KCl}$ dan urea masing-masing 1 kg dan ditambah EM4 yang sudah dilarutkan dengan gula jawa yang berfungsi untuk mengaktifkan bakteri dan mikroorganisme pada EM4, lalu ditambah dengan air sampai $3 / 4$ bagian tong besar (200 liter), kemudian ditutup dan disimpan selama 2-3 minggu.

- Penggunaan pupuk per lubang tanam untuk bibit yang baru ditanam sekitar $15 \mathrm{ml}$ per liter air, dilakukan secara rutin selama 4 bulan pertama per batang, 4 bulan kedua $30 \mathrm{ml}$ per liter air per batang, 4 bulan ketiga $350 \mathrm{ml}$ per liter air per batang (maksimal) dan seterusnya sampai pohon besar. 


\section{Perawatan}
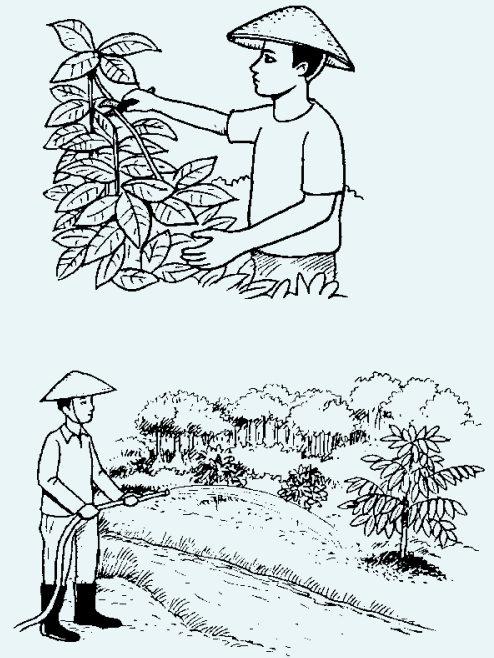

\section{Panen}

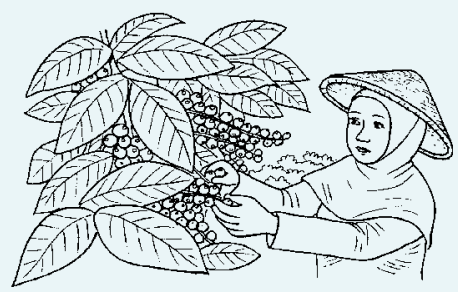

- Pembersihan pakis, gulma atau rumput di sekitar piringan pohon kopi yang sudah ditanam, dilakukan bila butuhkan.

- Penyiraman pohon kopi liberika disesuaikan dengan keadaan cuaca, seminggu 1-2 kali disiram dalam 1 bulan jika intensitas hujan rendah, 1-2 minggu sekali disiram dalam 1 bulan jika intensitas hujan sedang dan 1 bulan 1 kali disiram jika intensitas hujan tinggi.

- Pemangkasan dilakukan ketika tinggi pohon sudah mencapai $\pm 1,5-2$ meter (umur \pm 1 tahun). Pohon dipangkas tingginya 1,5-2 meter dan dibentuk menyerupai payung.

- Kopi liberika termasuk tanaman dengan sanitasi yang bersih, diharapkan sekitar piringan pohon kopi yang tertanam selalu bersih dari gulma dan sebagainya.

- Umur 2 tahun pohon kopi liberika belajar berbuah (buah pasir) dan buah pertama harus dibuang.

- Umur 2,5 tahun sudah mulai berbuah ceri.

- Kopi liberika akan siap dipanen ketika berumur 2,5-3 tahun.

- Panen raya terjadi dalam 4-5 bulan dengan interval pemetikan 2 minggu sekali pada pohon yang sama.

- Setelah panen, pohon kopi dipangkas dan dibuang cabang-cabang tuanya dan disesuaikan kembali tingginya ke posisi $1,5-2$ meter. 


\subsubsection{Pengelolaan kebun}

Dalam kegiatan ini, karena tidak ada sumber bibit kopi liberika di Desa Dompas, maka bibit didatangkan dari Kepulauan Meranti, Kabupaten Meranti dan Desa Parit I/II, Sungai Apit, Kabupaten Siak, Provinsi Riau. Bibit kopi liberika yang didatangkan berasal dari pohon induk bersertifikat dan sudah dipatenkan oleh Kementerian Pertanian dan Kementerian Hukum dan HAM dengan nama "Kopi Liberika Meranti".

\subsubsection{Pelatihan kopi dari petani ke petani}

Pelatihan kopi dilaksanakan pada 27-29 Januari 2019 dan hanya diikuti terbatas oleh pengelola arena aksi 4,5 dan 6. Pelatihan dilaksanakan di rumah dan kebun Bapak Atek Desa Dompas, Bukit Batu, Bengkalis dan studi banding ke kebun kopi liberika milik Bapak Misdi Desa Parit I/II, Sungai Apit, Kabupaten Siak. Trainer dalam kegiatan ini adalah Bapak Rudi Hidayat Sekretaris lembaga SAR'T. Konsep yang digunakan dalam pelatihan ini adalah pendekatan secara terfokus, diskusi dan tanya jawab, praktek lapangan secara langsung dan studi banding. Materi diskusi kopi liberika terdiri dari budidaya tanaman kopi liberika, termasuk di dalamnya pengelolaan kebun: cara tanam, jarak tanam, perlakuan, perawatan hingga pemanenan kopi liberika.

\subsubsection{Pustaka}

Ardiyani F. 2014. Potensi Perbanyakan Kopi Liberika dengan Metode Somatik Embriogenesis. Warta Pusat Penelitan Kopi dan Kakao 26:14-20.

de Foresta, Kusworo A, Michon G, Djatmiko W. 2000. Ketika Kebun Berupa Hutan: Agroforest Khas Indonesia Sebuah Sumbangan Masyarakat. Bogor: International Centre for Research in Agroforestry - Institute de Recherche pour le Development - Ford Foundation.

Gusfarina 2014. Mengenal Kopi Liberika Tungkal (Libtukom). Jambi: BPTP Provinsi Jambi. Hulupi R. 2014. Libtukom: Varietas Kopi Liberika Anjuran untuk Lahan Gambut. Warta Pusat Penelitian Kopi dan Kakao Indonesia, 26(1):1-16

Lisnawati A, Lahjie AM, Simarangkir BDAS, Yusuf S, Ruslim Y. 2017. Agroforestry System Biodiveristy of Arabica Coffee Cultivation in North Toraja District, South Sulawesi, Indonesia. Biodiversitas 18(2): 741-751.

Waluyo EA dan Nurlia A. 2017. Potensi Pengembangan Kopi Liberika (Coffea liberica) Pola Agroforestry dan Prospek Pemasarannya untuk Mendukung Restorasi Lahan Gambut di Sumatera Selatan (Belajar dari Kabupaten Tanjung Jabung Barat, Provinsi Jambi). Prosiding, Seminar Nasional Lahan Sub optimal Pengembangan Ilmu dan Teknologi Pertanian Bersama Petani Lokal untuk Optimalisasi Lahan Sub optimal 255-264, 19-20 Oktober 2017. Palembang, Indonesia: Pusat Unggulan Riset Pengembangan Lahan Suboptimal (PUR-PLSO) Universitas Sriwijaya. 


\subsection{BUDIDAYA NANAS DI LAHAN GAMBUT ${ }^{14}$}

\subsubsection{Restorasi lahan gambut melalui budidaya nanas}

Restorasi atau pemulihan lahan gambut yang rusak melalui budidaya nanas sudah dilakukan di beberapa daerah di Pulau Sumatera. Badan Restorasi Gambut mendorong budidaya nanas pada lahan gambut di Desa Pagaruyung, Kabupaten Kampar.15 Sementara itu, di Kabupaten Bengkalis, CIFOR bekerja bersama dengan PSB UNRI memfasilitasi budidaya wanatani nanas dalam rangka riset aksi partisipatif untuk pencegahan kebakaran dan restorasi gambut berbasis masyarakat. Wanatani nanas ini dikembangkan di Arena Aksi 2 dan 3 pada lahan seluas total 7 ha yang berada di Desa Dompas. Pada fase perencanaan (Planning Phase), pengelola arena aksi membuat model bisnis wanatani nanas. Sebagai tindak lanjut, di fase aksi (Action Phase) diadakan pelatihan budidaya nanas pada 10 Maret 2019. Acara pelatihan diawali dengan pemberian materi dan diskusi di kantor Desa Dompas dan dilanjutkan dengan praktik penanaman nanas dan diskusi di lapangan. Narasumber yang hadir dalam pelatihan nanas ini adalah Bapak Syamsul Hadi (petani nanas dan fasilitator Badan Restorasi Gambut) dari Kecamatan Sungai Apit, Kabupaten Siak. Pelatihan ini dilanjutkan dengan penanaman nanas dan tanaman kayu di Arena Aksi 2 dan 3.

Hasil riset CIFOR (IIham dkk. 2019) menunjukkan bahwa nanas merupakan salah satu komoditi yang produktif, menguntungkan dan ramah gambut; di samping pinang, ikan, dan madu. Budidaya nanas di lahan gambut baiknya dilakukan dengan pola wanatani (agroforestry) dan praktik-praktik terbaik (best practices) dalam penyiapan lahan, pembibitan, penanaman, dan penguatan berbagai jenis modal misalnya modal sosial, modal manusia, dan modal finansial.

14 Oleh: Dyah Puspitaloka, Syamsul Hadi dan Herry Purnomo

15 https://www.cendananews.com/2019/04/budidaya-nanas-di-lahan-gambut-riau-membuahkan-hasil.html 


\subsubsection{Budidaya nanas}

\section{A. Pemilihan bibit}

Pemilihan bibit perlu dilakukan sebelum penanaman. Bibit nanas yang tidak sehat perlu dibuang. Bibit juga perlu dipilih berdasarkan ukuran dan asal bibit (Hadiati dan Indriyani 2008). Menurut Cyber Extension Kementerian Pertanian, bibit dapat berupa mahkota, tunas batang, dan tunas akar. Beberapa ciri-ciri bibit yang baik:

- Berasal dari tanaman induk yang normal dan sehat,

- Jenis bibit seragam atau berasal dari satu jenis. Misalnya tidak mencampurkan bibit yang berasal dari tunas akar dengan bibit yang berasal dari mahkota.

\section{B. Persiapan lahan dan penanaman}

Persiapan lahan gambut dilakukan dengan menghindari penggunaan api dan alat berat karena kedua teknik ini dapat merusak gambut. Dalam riset aksi partisipatif, persiapan lahan budidaya nanas dilakukan secara manual melalui pembersihan semak belukar dan tunggul tanaman, yang berpotensi mengganggu pertumbuhan tanaman (tebang imas). Kemudian, lahan disemprot dengan herbisida untuk mematikan gulma. Setelah itu, dibuat jalur tanam sesuai dengan pola tanam satu baris atau dua baris. Menurut Hadiati dan Indriyani (2008), jarak antar jalur dapat dibuat sekitar 80-100 cm dan jarak antar nanas adalah 35-50 cm (Gambar 6.5). Pada pola wanatani, penanaman nanas perlu menyesuaikan dengan rencana penanaman pohon kayu. Pada proyek riset aksi partisipatif di Dompas, penanaman nanas dilakukan dengan jarak antar nanas $70 \mathrm{~cm}$ dan jarak antar jalur $100 \mathrm{~cm}$.
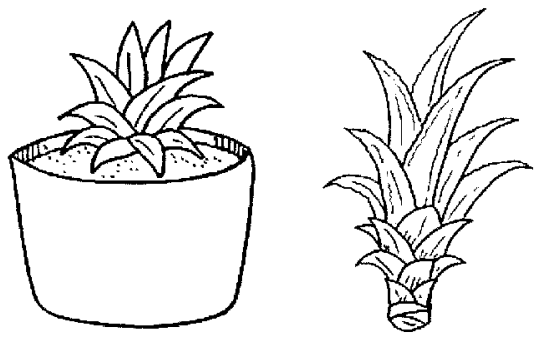

\section{Pemilihan bibit}

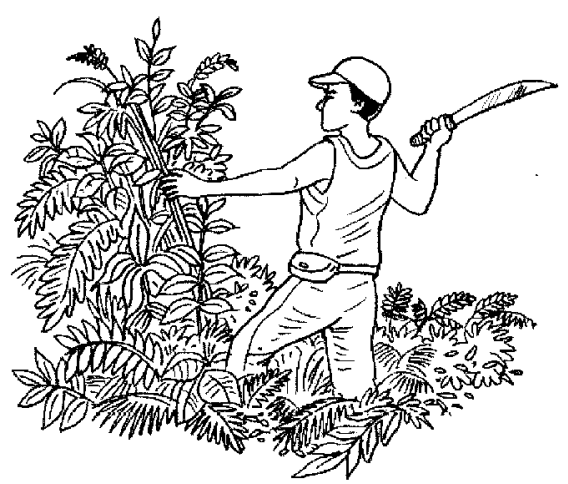

Pembersihan lahan tanpa bakar dengan cara tebang imas

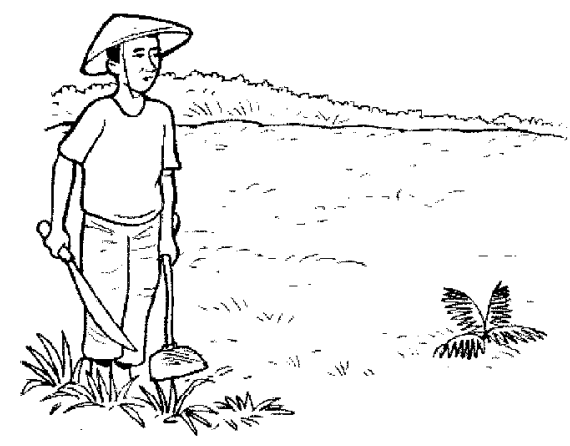




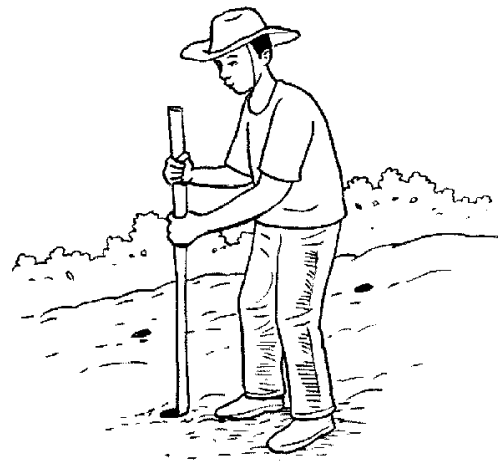

Pembuatan lubang tanam

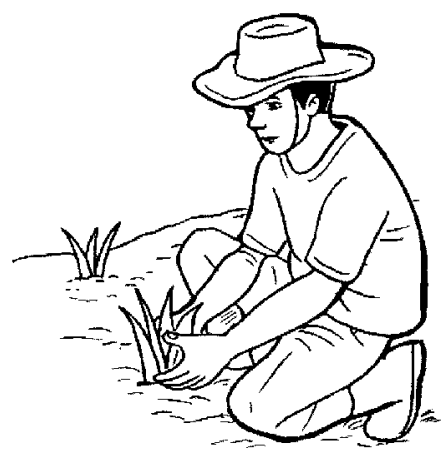

Penanaman nanas

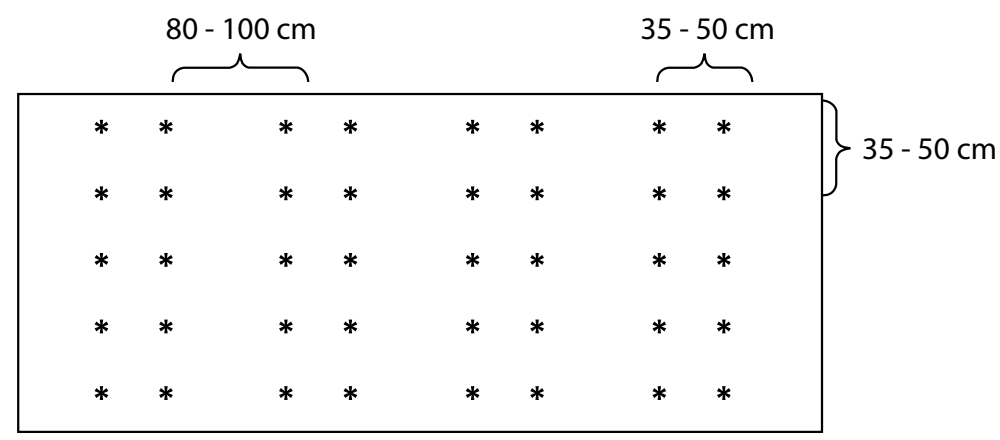

Gambar 6.5. Contoh pola tanam nanas dua baris berdasarkan Hadiati dan Indriyani (2008). Pada PAR CBFPR di Dompas, jarak antar nanas dibuat menjadi $70 \mathrm{~cm}$ dan jarak jalur $100 \mathrm{~cm}$.

Menurut Hadiati dan Indriyani (2008) dan Cyber Extension Kementerian Pertanian (2010), benih nanas ditanam 5 sampai $10 \mathrm{~cm}$ tergantung ukuran kelas bibit atau panjang bibit. Agar bibit tidak mudah roboh, tanah di sekitar pangkal batang perlu dipadatkan. Kemudian, siram tanaman sampai tanah lembab dan basah. 


\section{Pemeliharaan (pemupukan, penyiangan, penjarangan, dan penyiraman)}

\section{Pemupukan}

Secara umum, ada dua macam pemupukan untuk tanaman nanas yakni pupuk dasar dan pupuk susulan. Dosis pupuk yang diberikan bergantung pada kebutuhan tanaman dan kondisi lahan (Hadiati dan Indriyani 2008). Tabel 6.2 adalah ringkasan pemberian pupuk dasar dan pupuk susulan untuk budidaya nanas.

\section{Penjarangan}

Buah nanas yang besar dan bagus dapat dihasilkan melalui penjarangan anakan. Dalam setiap rumpun maksimal jumlah anakan adalah 2 anakan (Hadiati dan Indriyani 2008).

\section{Penyiangan}

Agar hasil panen maksimal, lahan budidaya tanaman nanas perlu disiangi agar bebas dari rumput liar. Penyiangan dapat dilakukan secara berkala (2-4 kali selama masa tanam) bersamaan dengan penjarangan. ${ }^{16}$

\section{Penyiraman}

Hadiati dan Indriyani (2008)

mengemukakan pentingnya penyiraman nanas sampai umur tanaman 1-2 bulan. Apabila kondisi tanah terlalu kering, maka pertumbuhan nanas lambat dan hasil buahnya kecil. Penyiraman dilakukan minimal 1 minggu sekali terutama di musim kemarau. Saat tanaman sudah dewasa, penyiraman cukup dilakukan 2 minggu sekali. ${ }^{17}$

16 http://cybex.pertanian.go.id/artikel/17469/budidayananas/

17 https://www.infoagribisnis.com/2015/06/budidayananas/

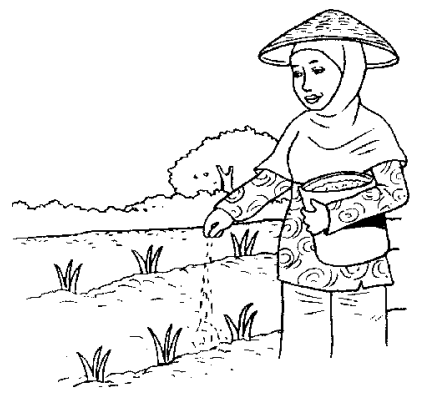

\section{Pemupukan nanas}
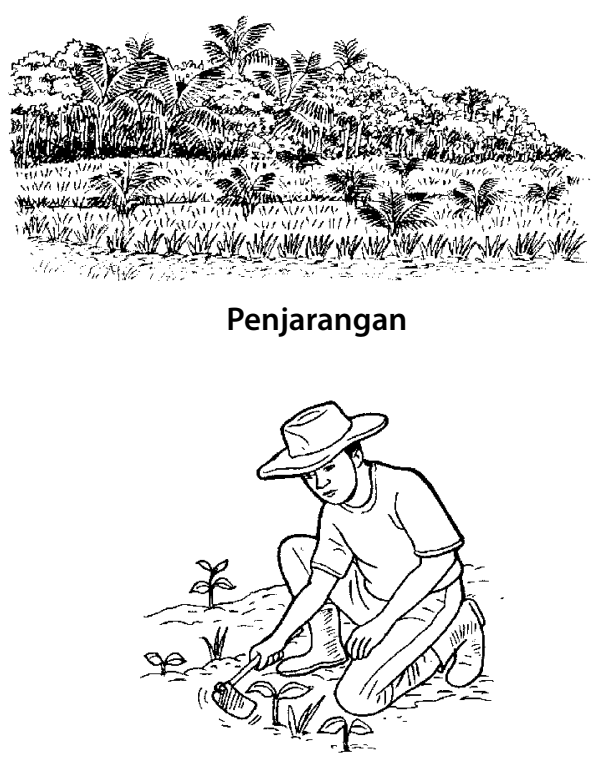

Penyiangan

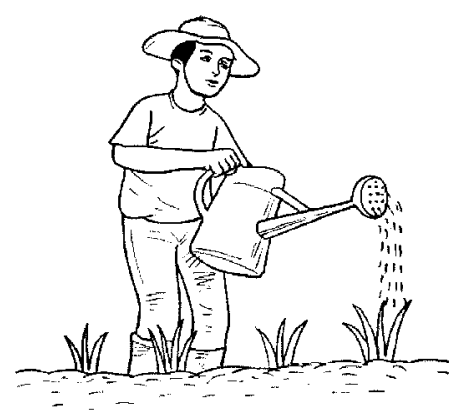

Penyiraman 
Tabel 6.2 Pemberian pupuk pada tanaman nanas.*

\begin{tabular}{|c|c|c|}
\hline Jenis Pupuk & Dosis Pupuk Per Hektar & $\begin{array}{c}\text { Waktu Pemberian } \\
\text { Pupuk }\end{array}$ \\
\hline $\begin{array}{l}\text { Pupuk dasar berupa: } \\
\text { - Pupuk kandang. }\end{array}$ & 10 ton. & Setelah penanaman. \\
\hline $\begin{array}{l}\text { Pupuk susulan pertama: } \\
\text { - Urea. } \\
\text { - Terusi/ tembaga sulfat } \\
\left(\mathrm{CuSO}_{4}\right) \text {. }\end{array}$ & $\begin{array}{l}300 \mathrm{~kg} . \\
5-10 \mathrm{~kg} .\end{array}$ & $\begin{array}{l}\text { Setelah penanaman, } \\
\text { saat usia nanas } \\
2 \text { - } 3 \text { bulan. }\end{array}$ \\
\hline $\begin{array}{l}\text { Pupuk susulan kedua: } \\
\text { - Urea. } \\
\text { - Terusi/ tembaga sulfat } \\
\left(\mathrm{CuSO}_{4}\right) \text {. } \\
\text { - } \mathrm{TSP} . \\
\text { - } \mathrm{KCl} \text {. }\end{array}$ & $\begin{array}{l}300 \mathrm{~kg} . \\
5-10 \mathrm{~kg} . \\
\text { menyesuaikan jika diperlukan. } \\
\text { menyesuaikan jika diperukan. }\end{array}$ & Usia nanas 5 - 6 bulan. \\
\hline
\end{tabular}

Pupuk susulan ketiga (jika

ingin pertumbuhan batang nanas yang besar):

- Etrel /ZPT(Zat Pengatur Tumbuh Tanaman).

- Urea.

$150 \mathrm{ml}$.

Usia nanas 9 - 10.

$100 \mathrm{~kg}$.

Pupuk susulan keempat

(jika ingin buah lebih

Usia Nanas 11 -

besar):

$250 \mathrm{~kg}$.

12 bulan, ditandai

- Urea.

$5 \mathrm{~kg}$.

dengan keluarnya

- Terusi/ tembaga sulfat

putik/buah nanas. (CuSO 4 ).

$250 \mathrm{~kg}$.

- $\mathrm{KCl}$.

*Dosis pupuk ini diperoleh dari literatur dan narasumber pelatihan nanas.

Tabel 6.3 Perkiraan waktu panen nanas.

\begin{tabular}{lc}
\hline \multicolumn{1}{c}{ Jenis Bibit } & \multicolumn{1}{c}{ Waktu Panen } \\
\hline Bibit berasal dari tunas batang. & 18 bulan setelah tanam. \\
\hline Bibit berasal dari anakan. & $15-18$ bulan setelah tanam. \\
\hline Bibit berasal dari mahkota. & 24 bulan setelah tanam. \\
\hline
\end{tabular}




\section{Pemanenan}

Berdasarkan Hadiati dan Indriyani (2008), waktu panen nanas berbeda-beda, bergantung pada varietas dan bibit yang digunakan. Tabel 6.3 adalah perkiraan waktu panen berdasarkan jenis bibit yang digunakan.

Adapun ciri-ciri nanas yang sudah siap panen menurut Hadiati dan Indriyani (2008) adalah sebagai berikut:

- Mahkota nanas lebih terbuka,

- Tangkai buahnya keriput,

- Mata nanas lebih datar dan bentuknya lebih bulat,

- Warna kulit pada bagian dasar buah

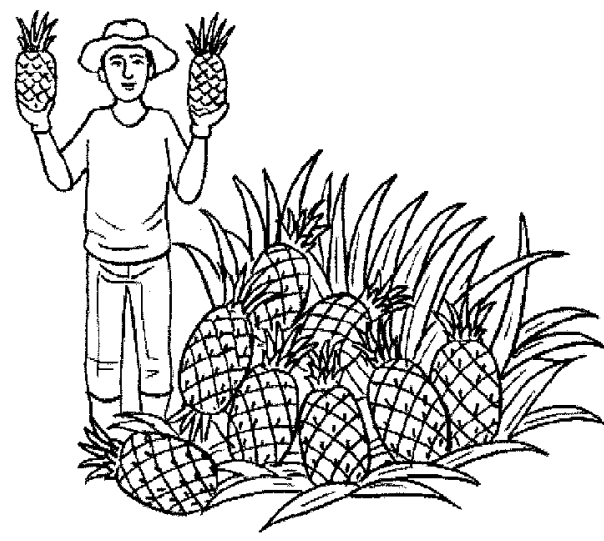

Pemanenan mulai menguning,

- Aroma buah nanas mulai muncul.

Setelah ciri-ciri di atas muncul, pilihlah buah nanas yang siap dipanen. Kemudian, potong miring pangkal tangkai buah dan letakkan buah di tempat teduh agar tidak layu.

\subsubsection{Pustaka}

Cyber Extension Kementerian Pertanian. 2010. Budidaya nanas. [diakses tanggal 5 Mei 2019]. http://cybex.pertanian.go.id/artikel/17469/budidaya-nenas/

Hadiati S. dan Indriyani NLP. 2008. Petunjuk teknis budidaya nanas. Solok: Balai Penelitian Tanaman Buah Tropika.

Hidayat M. 2019. Budidaya nanas di lahan gambut Riau membuahkan hasil. [diakses 5 Mei 2019]. https://www.cendananews.com/2019/04/budidaya-nanas-di-lahangambutriau-membuahkan-hasil.html

Ilham QP, Purnomo H, Rohadi D, dan Puspitaloka D. 2019. Value chain analysis for hazefree livelihoods in peatlands. Working paper. Bogor: CIFOR.

Info Agribisnis. 2015. Teknik budidaya nanas: baca langkah-langkah pembibitan hingga panenan buah nanas. [diakses 5 Mei 2019]. https://www.infoagribisnis.com/2015/06/ budidaya-nanas/ 


\subsection{BUDIDAYA KELAPA HIBRIDA DI LAHAN GAMBUT ${ }^{18}$}

Kegiatan riset aksi partisipatif pencegahan kebakaran dan restorasi gambut berbasis masyarakat di Desa Dompas memiliki banyak aktivitas, tidak hanya terfokus pada arena aksi saja tetapi ada kegiatan yang terfokus di sekitar lingkungan pemukiman masyarakat. Kegiatan tersebut, yaitu revitalisasi perekonomian masyarakat. Mekanisme yang dilakukan adalah dengan melakukan penanaman kelapa hibrida di setiap pekarangan rumah milik warga.

Kelapa hibrida dipilih warga berdasarkan hasil wawancara dan diskusi terpadu tentang jenis-jenis pohon prioritas yang ingin ditanam masyarakat. Dalam prosesnya, dari total 351 masyarakat yang diwawancara, 311 orang diantaranya berminat untuk menanam kelapa hibrida. Hasil tersebut diperoleh dari gabungan 8 Rukun Tetangga (RT), Dusun Murni dan Dusun Lestari di Desa Dompas.

Selain diajak berdiskusi dan diwawancara, masyarakat yang berminat menanam kelapa hibrida juga diberikan pelatihan secara khusus tentang budidaya kelapa hibrida yang dilaksanakan di Kantor Desa Dompas pada tanggal 18 Desember 2018 oleh Bapak Joko Paryanto dari Usaha Pembibitan Hijau Tani Siak dan Bapak Tarsono dari Yayasan Bina Cinta Alam Siak. Selain teori tentang budidaya, sebanyak 38 anggota masyarakat juga terlibat dalam kegiatan praktek lapangan untuk mengetahui bagaimana cara menanam kelapa hibrida yang baik dan benar.

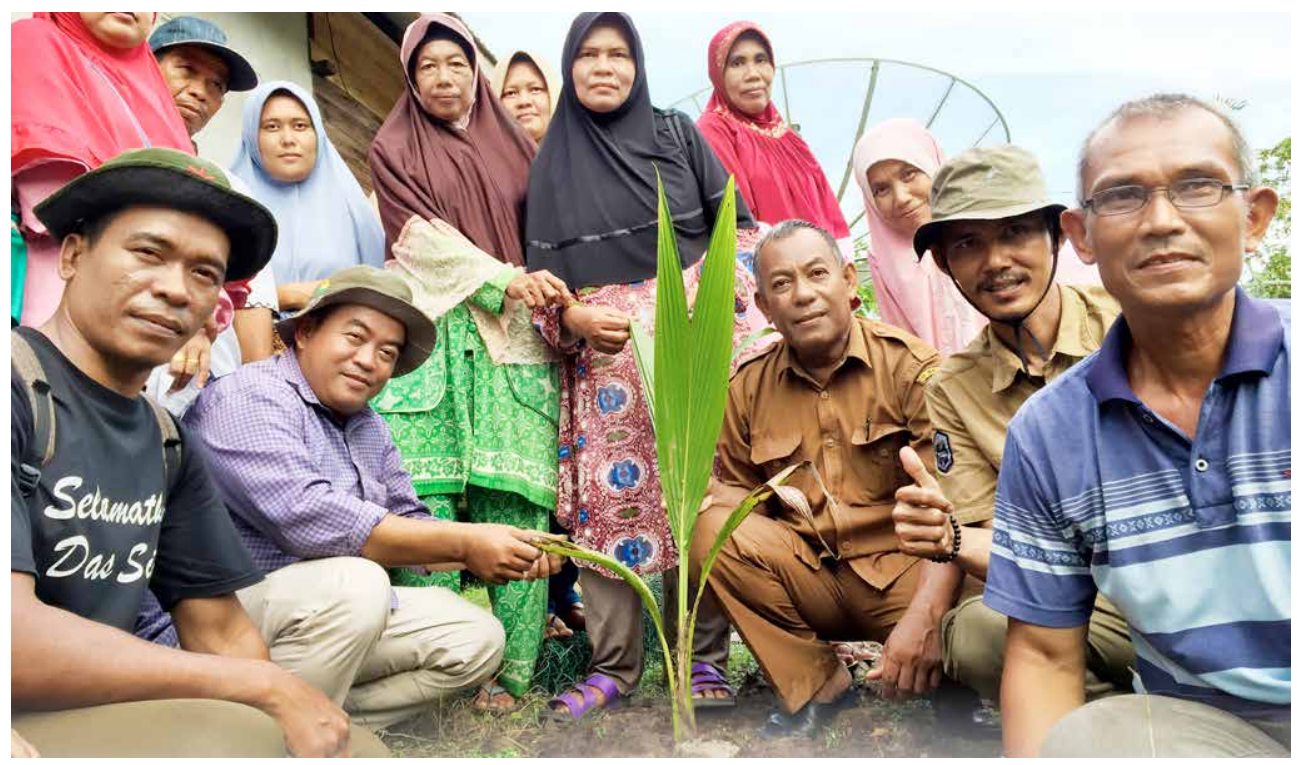

18 Oleh: Pandam Nugroho Prasetyo, Joko Paryanto, Tarsono, dan Herry Purnomo. 
Pembagian bibit kelapa dilakukan 3 minggu (17 Januari 2019) setelah kegiatan pelatihan selesai, dengan alasan warga yang dapat giliran pertama pembagian kelapa hibrida sudah selesai membuat lubang tanam $(40 \times 40 \mathrm{~cm})$ dan memasukan pupuk kadang atau pupuk organik didalamnya yang dicampur dengan SP36 sesuai dengan ketentuan pada saat pelatihan dilakukan. Pendistribusian kelapa hibrida dibagi secara bertahap per 3 RT dimulai dari RT 7, 8, 1 dst. Pendistribusian akan berlanjut jika warga dari ketiga RT tersebut sudah selesai menanam dan 3 RT selanjutnya sudah menyiapkan lubang tanam. Proses pendistribusian seperti ini dilakukan dengan tujuan mendisiplinkan

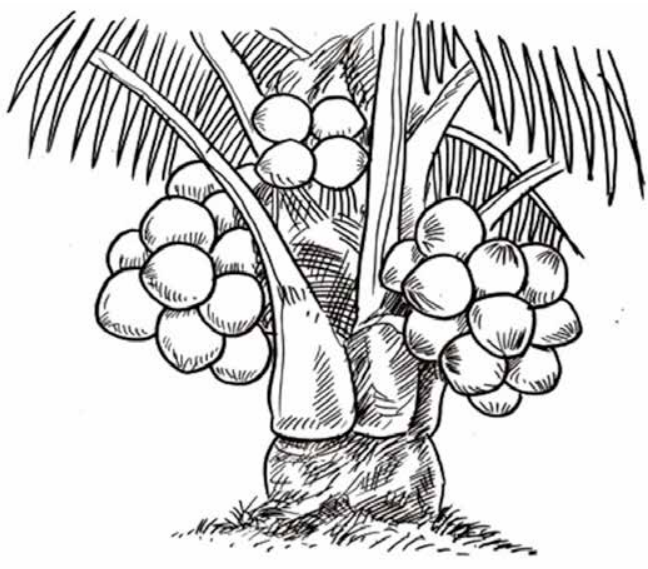
masyarakat untuk bisa berkomitmen menjalankan program ini secara berkelanjutan.

\subsubsection{Sekilas kelapa hibrida}

Kelapa hibrida (Cocos nucifera) merupakan jenis kelapa persilangan antara varietas genjah (sebagai ibu) dengan varietas dalam (sebagai bapak) untuk mendapatkan varietas unggul atau sifat-sifat kelapa unggul dari kedua induknya. Secara umum hal ini bertujuan untuk meningkatkan produksi buah kelapa yang banyak dan dapat meningkatkan perekonomian masyarakat.

\subsubsection{Keunggulan kelapa hibrida}

Secara umum, kelapa hibrida memiliki batang yang relatiflebih pendekjika dibandingkan dengan kelapa pada umumnya. Keunggulan kelapa hibrida jika dibandingkan dengan jenis kelapa lain, yaitu karena kemampuan pohon kelapa hibrida untuk bisa beradaptasi dengan baik di lahan gambut, produktivitas yang tinggi dan cepat ( 2 tahun berbunga, 3 tahun sudah mulai berbuah dengan jumlah sekitar 5-7 butir kelapa per tandan. Pada umur 4-5 tahun sudah bisa berproduksi dengan jumlah 10-20 butir kelapa per tandan. Buah kelapa hibrida berukuran cukup besar (menyerupai kelapa dalam), daging kelapa tebal dan agak keras serta memiliki kandungan minyak yang tinggi ${ }^{19}$. 


\subsubsection{Cara menanam kelapa hibrida}

Bibit kelapa hibrida didatangkan dari Kota Medan, Sumatera Utara dan Kabupaten Indragiri Hilir, Provinsi Riau melalui dukungan dari usaha Pembibitan Hijau Tani, Desa Benteng Hilir Kabupaten Siak.

Berikut ini adalah tahapan untuk menanam pohon kelapa pada skala perumahan berdasarkan pengalaman yang dilakukan oleh petani kelapa hibrida di Kabupaten Siak:

\section{Penyeleksian bibit \& aklimatisasi}

\section{- Pemilihan bibit}

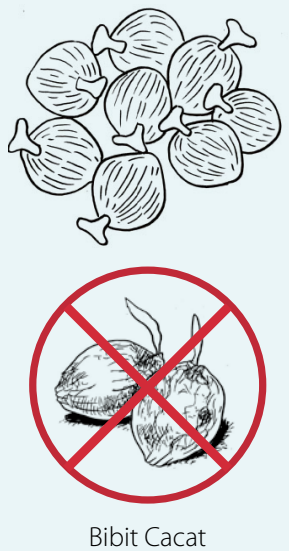

- Aklimasi

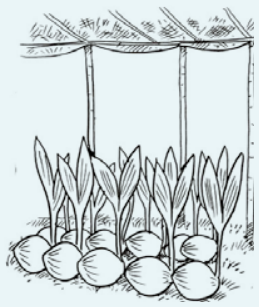

\section{Pohon induk}

- Pastikan pohon induk telah berumur sekitar 20-40 tahun.

- Pohon berkualitas bagus: menghasilkan buah secara terus menerus sepanjang tahun, bebas dari gangguan hama atau penyakit, mahkota merata dengan bentuk seperti payung terbuka.

\section{Ciri-ciri buah yang baik untuk dijadikan bibit}

- Bentuk bundar atau setengah bundar dan utuh (tidak cacat).

- Berukuran sedang dengan ukuran panjang $22-25 \mathrm{~cm}$ dan lebar $17-20 \mathrm{~cm}$.

- Buah telah masak dengan kulit luar licin, tidak cacat dan tidak terserang hama penyakit.

\section{Aklimatisasi}

Aklimatisasi bibit kelapa hibrida di pembibitan berlangsung sekitar 3-4 minggu setelah bibit tiba di lokasi. 


\section{Persiapan lahan}

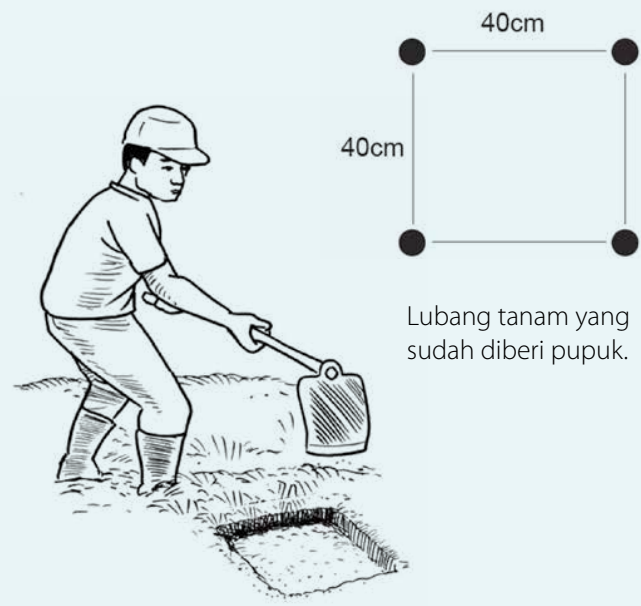

\section{Penanaman}

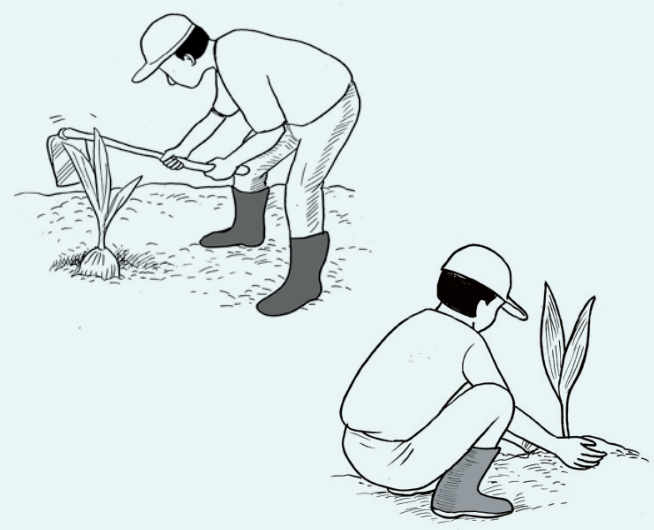

\section{Penanaman}

- Tanam bibit kelapa hibrida pada posisi yang benar dan pastikan bibit tersebut terkena paparan sinar matahari yang cukup.

- Pangkal batang jangan terlalu tertimbun karena titik tumbuh masih berada di bawah (Pastikan $1 / 3$ bagian bibit kelapa hibrida masih nampak diatas tanah) dan kalau tertimbun, pertumbuhannya akan mengalami hambatan. 
Kotak sambungan

\section{Perawatan}

\section{- Penyiraman}

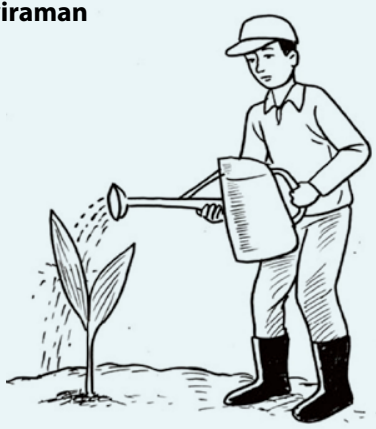

- Penyiangan

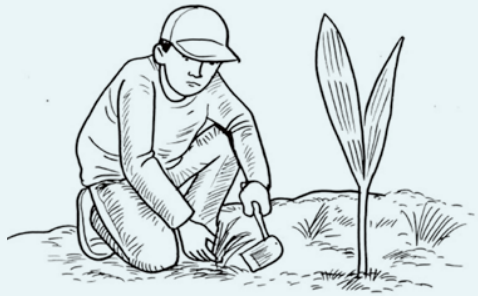

- Pemberantasan hama penyakit

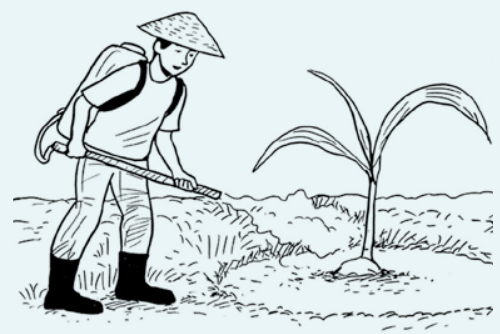

\section{Penyiraman}

- Penyiraman harus diberikan secukupnya. Pada musim kemarau dilakukan setiap hari. Air siraman yang diperlukan tergantung pada umur bibit, semakin tua semakin banyak air dibutuhkan. Rata-rata kebutuhan air, mulai umur bibit 1 - 6 bulan adalah $1 / 2-3$ liter/hari/bibit.

\section{Penyiangan}

- Pembersihan rumput dan gulma disekitar piringan pohon dan penggemburan tanah dibutuhkan jika tanah terlalu keras (liat).

\section{Pemberantasan hama penyakit}

- Penyemprotan dengan insektisida maupun fungisida dilakukan ketika ada tanaman yang terkena penyakit. 


\section{Perawatan}

\section{- Pemupukan}

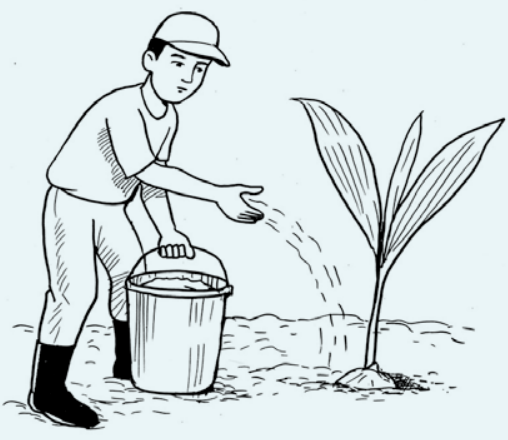

\section{- Panen}

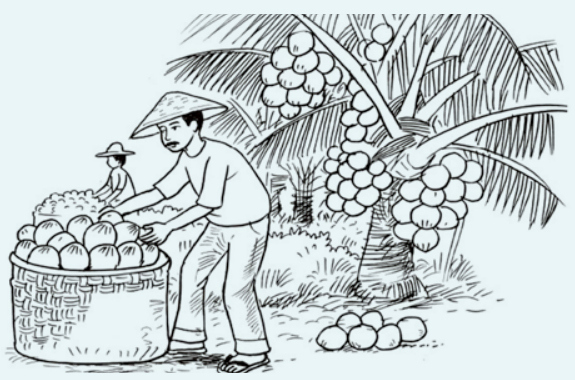

\section{Pemupukan}

- Pemupukan dilakukan setelah 1 bulan bibit kelapa hibrida tertanam dengan menambahkan urea dengan dosis $100 \mathrm{gr}$ per pohon. Pemupukan selanjutnya baru dilakukan setahun setelah bibit tertanam. Pupuk yang diberikan yaitu pupuk tunggal seperti SP36 dan dilanjut dengan menambahkan $\mathrm{KCl}$ setelah 3 bulan dengan dosis 250 gr. Pupuk diberikan di sekitar piringan pohon bukan langsung pada tanaman.

\section{Pemanenan dan Pemangkasan}

- Pohon kelapa hibrida mulai belajar berbuah pada saat berumur 3 tahun dan mulai bisa diproduksi atau dipanen pada saat berumur 4-5 tahun.

- Pemangkasan dilakukan dengan cara membuang pelepah daun kelapa yang sudah tua. 


\subsubsection{Pustaka}

Dinas Perkebunan Provinsi Sulawesi Selatan. 2019. Budidaya Kelapa Hibrida. [diakses 5 Mei 2019]. http://www.ternakku.net/2016/10/Budidaya-Kelapa-Hibrida.html

\section{Pernyataan Penyangkalan (Disclaimer):}

Panduan teknis budidaya kopi liberika, nanas, dan kelapa hibrida ini disusun dalam rangka riset aksi partisipatif pencegahan kebakaran dan restorasi gambut berbasis masyarakat di Desa Dompas, Kecamatan Bukit Batu, Kabupaten Bengkalis, Provinsi Riau (2018-2019). Informasi dalam panduan ini berasal dari literatur dan narasumber pada pelatihan budidaya yang dilaksanakan di Desa Dompas. Panduan teknis budidaya ini telah disesuaikan dengan kondisi yang ada di Desa Dompas. Budidaya di daerah lain mungkin membutuhkan teknik yang berbeda, bergantung pada kesesuaian lahan maupun kondisi prasyarat lainnya. 



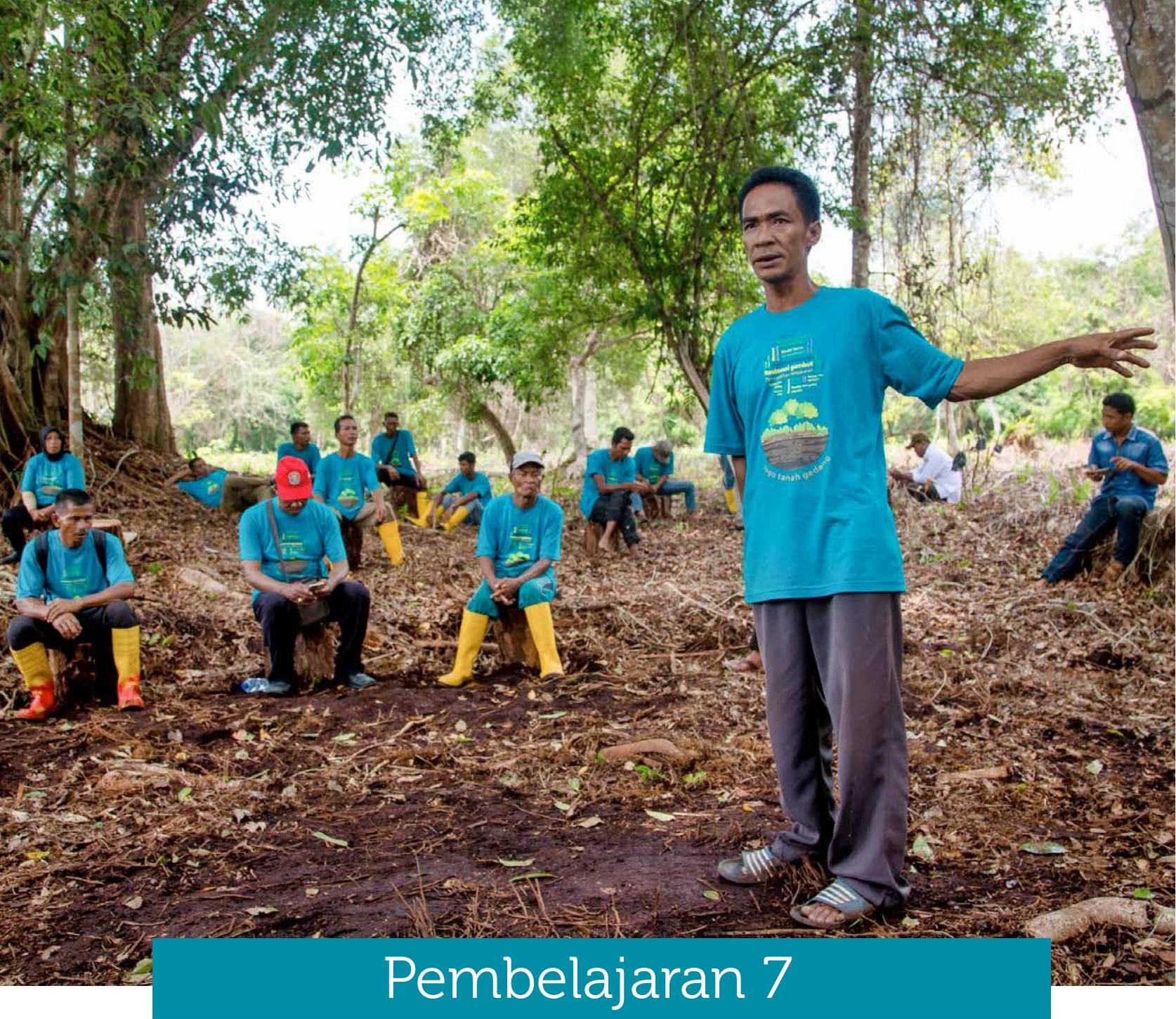

Penguatan Masyarakat Peduli Api

Pembelajaran dari Sebuah Riset

Aksi Partisipatif

Agus Andrianto, Heru Komarudin, Dyah Puspitaloka, Rozi, Deden Djaenudin dan Aenunaim 


\subsection{LATAR BELAKANG}

Paradigma pencegahan dan penanggulangan kebakaran hutan dan lahan di Indonesia sudah mengalami perubahan ke arah yang lebih komprehensif dan strategis. Perubahan tersebut berawal setelah terjadinya kebakaran besar pada tahun 2015, yang ditandai dengan munculnya kesadaran para pihak bahwa kebakaran hutan dan lahan tidak semata-mata dapat diselesaikan dengan pemadaman yang reaktif tetapi perhatian lebih perlu diarahkan pada upaya-upaya pencegahan. ${ }^{20}$ Kebakaran tidak dapat ditanggulangi hanya oleh satu atau beberapa lembaga saja. Keterlibatan pemangku kepentingan yang lebih luas, termasuk masyarakat setempat, adalah salah satu faktor penentu dalam pencegahan dan penanganan kebakaran. ${ }^{21}$ Pentingnya peran strategis masyarakat tersebut tercermin dalam Instruksi Presiden Republik Indonesia tahun $2016^{22}$ yang memandatkan pembentukan dan penguatan Masyarakat Peduli Api (MPA). Saat ini sudah terdapat 704 regu MPA dengan anggota sejumlah 10.569 orang yang tersebar di 28 provinsi.

MPA dibentuk atas inisiatif Kementerian Lingkungan Hidup dan Kehutanan bersama pemerintah daerah dengan tujuan membangun kelembagaan masyarakat sebagai bagian dari upaya-upaya pencegahan, penanggulangan, maupun penanganan setelah kejadian kebakaran. Namun demikian masih terdapat berbagai kendala yang dihadapi MPA untuk mencapai tujuan tersebut, termasuk lemahnya kemampuan kelompok dalam berorganisasi dan membangun aksi kolektif, kurangnya pemahaman gugus tugas sebagai relawan, terbatasnya sarana, prasarana dan dukungan pembiayaan, serta kurangnya kerja sama para pihak. Berbagai penelitian sebelumnya di Riau menunjukkan bahwa peran MPA dalam pencegahan dan penanggulangan kebakaran hutan dan lahan masih terkendala oleh hubungan antara MPA dengan pemerintah daerah (Meiwanda 2016), cara-cara penanggulangan kebakaran (Evayanti dan Zulkarnaini 2014), dan kurang efektifnya komunikasi dan peringatan dini kebakaran (Badri dkk. 2018).

Meskipun komitmen dan upaya untuk memperkuat MPA sudah ada, namun pendekatan yang dilakukan masih kurang tepat dalam mencapai sasaran dan kurang memperhatikan kondisi dan kebutuhan yang sebenarnya, termasuk dinamika dalam kelompok masyarakat. Oleh karena itu dibutuhkan suatu panduan atau alat bantu yang dibangun berdasarkan pembelajaran-pembelajaran yang dialami langsung oleh kelompok masyarakat. Bab ini akan bermanfaat untuk memandu tahap demi tahap yang diperlukan MPA dalam memenuhi syarat dan kebutuhan teknis, prosedural dan

\footnotetext{
20 http://cifor.org/fire-and-peatland-restoration/

21 Instruksi Presiden No. 11 Tahun 2015 tentang Peningkatan Pengendalian Kebakaran Hutan dan Lahan

22 Rapat koordinasi nasional dalam mengendalikan kebakaran hutan dan lahan.
} 
administrasi, yang pada gilirannya akan membantu mengatasi masalah secara tepat dan sesuai dengan karakteristik dan kondisi setempat, sehingga akan meningkatkan keberdayaan MPA.

\subsection{PENGUATAN MASYARAKAT PEDULI API: SEBUAH PEMBELAJARAN BERBASIS RISET AKSI}

Pemberdayaan kelembagaan masyarakat adalah upaya untuk memberikan daya (empowerment) atau penguatan (strengthening) kepada masyarakat. Pemberdayaan masyarakat juga diartikan sebagai kemampuan individu yang bersenyawa dengan masyarakat dalam membangun keberdayaan masyarakat yang bersangkutan, yang bertujuan untuk menemukan alternatif-alternatif baru dalam pembangunan masyarakat (Mardikanto 2014). Penguatan MPA menjadi salah satu langkah penting untuk lebih menyiapkan kelompok masyarakat agar berperan dalam menghadapi kebakaran hutan dan lahan. Hal ini penting mengingat masalah kebakaran tidak dapat ditanggulangi sendiri oleh instansi pemerintah atau perusahaan hanya dengan menggunakan kewenangan, sumber daya dan peralatan yang mereka miliki. Lokasi kebakaran hutan dan lahan yang sangat tersebar, baik di kawasan konservasi, kawasan budidaya yang berada di dalam penguasaan konsesi, maupun di lahan-lahan yang dikelola oleh masyarakat, mempersulit upaya pemadaman yang efektif. Hal ini diperparah dengan kondisi iklim, timbunan biomassa kering, dan kondisi hidrologi yang justru lebih menyulut terjadinya kebakaran. Oleh karena itu, perlu adanya kolaborasi lintas sektoral dan partisipasi berbagai pihak, termasuk masyarakat dalam menangani kebakaran hutan dan lahan.

Pembelajaran ini disusun berdasarkan sebuah riset aksi partisipatif yang dilakukan pada lima MPA di Kecamatan Bukit Batu, Kabupaten Bengkalis, Provinsi Riau. Hasil analisis diskusi kelompok terarah dan wawancara menunjukkan variasi kinerja MPA dan berbagai kendala yang dihadapi kelompok masyarakat tersebut dalam mencapai tujuan. Hasil-hasil diskusi para pemangku kepentingan di tingkat nasional dan daerah, termasuk Direktorat Jenderal Pengendalian Perubahan Iklim, Direktorat Pengendalian Kebakaran Hutan dan Lahan, Manggala Agni Daops Siak, KPH Bengkalis, Badan Lingkungan Hidup Kabupaten Siak dan Dinas Pemadaman Kebakaran Kabupaten Bengkalis, menunjukkan bahwa agar tujuan yang dimandatkan kepada MPA dapat tercapai dan dalam rangka menguatkan kelembagaan MPA, maka perlu dilakukan berbagai perbaikan untuk menjawab tuntutan yang berkembang sesuai dengan waktu dan kebutuhan riil saat ini. 


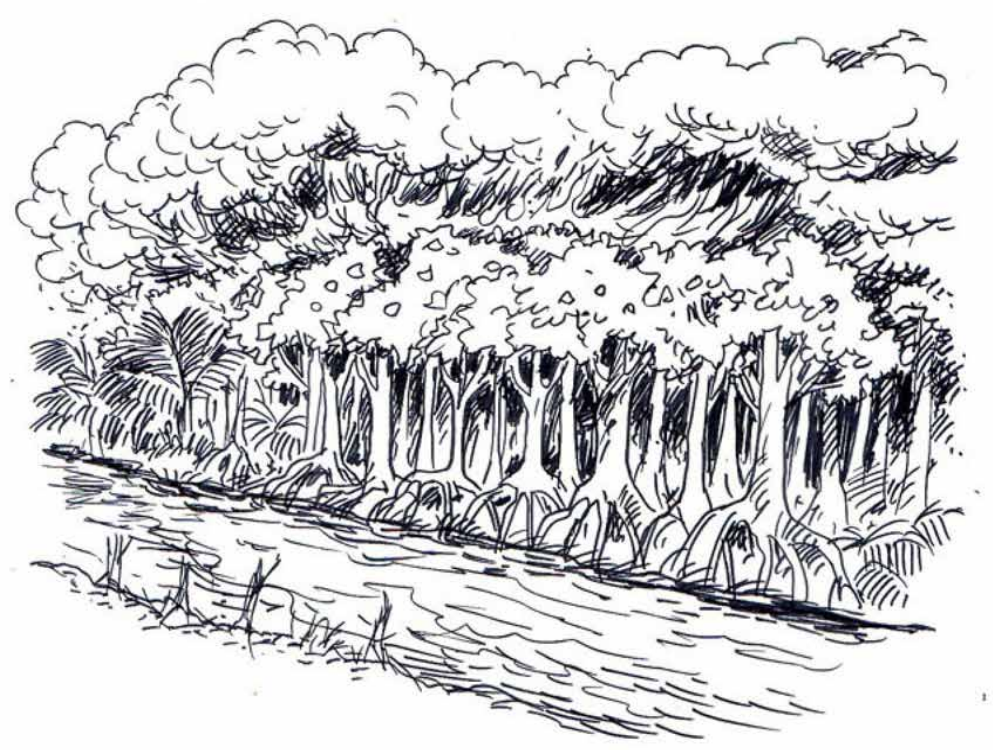

\section{Gambar 7.1 Ilustrasi lahan gambut yang terbakar}

MPA dituntut untuk bekerja secara aktif, sukarela dan bertanggung jawab. Marnelly (2018) menyatakan tiga permasalahan yang sering dihadapi MPA dalam tiga kategori: 1) kendala lingkungan kerja, yaitu terkait keselamatan kerja; 2) kendala lingkungan masyarakat, yaitu terkait kurangnya partisipasi masyarakat dalam memadamkan lahan terbakar; dan 3) kendala lingkungan alam, yaitu sulitnya memadamkan kebakaran di lahan gambut.

\subsubsection{Tujuan}

Mengingat situasi yang dijelaskan sebelumnya, maka pembelajaran penguatan MPA ini disusun dengan tujuan untuk membantu mengidentifikasi dan memecahkan permasalahan teknis, prosedural dan administrasi yang selama ini menjadikan MPA kurang berdaya dan kurang efisien dalam menjalankan perannya. Dengan teridentifikasinya permasalahan dan tersedianya opsi untuk mengatasinya, para pemangku kepentingan terkait dapat menanggulangi permasalahan dengan lebih baik dan menguatkan MPA secara tepat. Secara spesifik bab ini membahas:

1. Definisi dan peran aktual MPA sesuai dengan tujuan yang diharapkan

2. Deskripsi detail fungsi dari struktur MPA, sekaligus peran lembaga mitranya

3. Panduan kerja, pelaporan kegiatan dan pertanggungjawaban keuangan

4. Panduan pemantauan dan patroli

5. Penguatan MPA 


\subsubsection{Profil singkat MPA di Kecamatan Bukit Batu dan Kecamatan Siak Kecil, Kabupaten Bengkalis}

MPA di Desa Dompas, Desa Sejangat, Kelurahan Pakning Asal, Desa Sukajadi, Desa Tanjung Belit dan Desa Buruk Bakul beranggotakan 7 sampai 15 orang, yang keanggotaannya disahkan melalui Surat Keputusan Pemerintah Desa. Dalam menjalankan tugasnya, MPA di desa-desa ini didukung oleh sarana dan prasarana serta dana operasional, dengan tingkat kelengkapan dan jumlah yang bervariasi. Sarana dan prasarana serta biaya operasional MPA diperoleh dari sumber-sumber eksternal maupun internal kelompok (swadaya). Dana operasional, misalnya, dianggarkan rutin oleh pemerintah daerah dengan variasi besaran yang berkisar antara Rp 10.000.000,- sampai dengan Rp 16.000.000,- per tahun, bergantung pada tingkat kerawanan kebakaran. Beberapa desa yang berbatasan langsung dengan perusahaan mendapatkan insentif tambahan sebesar Rp 80.000/hari untuk anggota yang melakukan kegiatan patroli dan laporan pencegahan kebakaran di area desa dan perbatasan wilayah perusahaan. Selain untuk melakukan kegiatan rutin, seperti patroli, dana operasional juga digunakan untuk penanganan kejadian kebakaran.

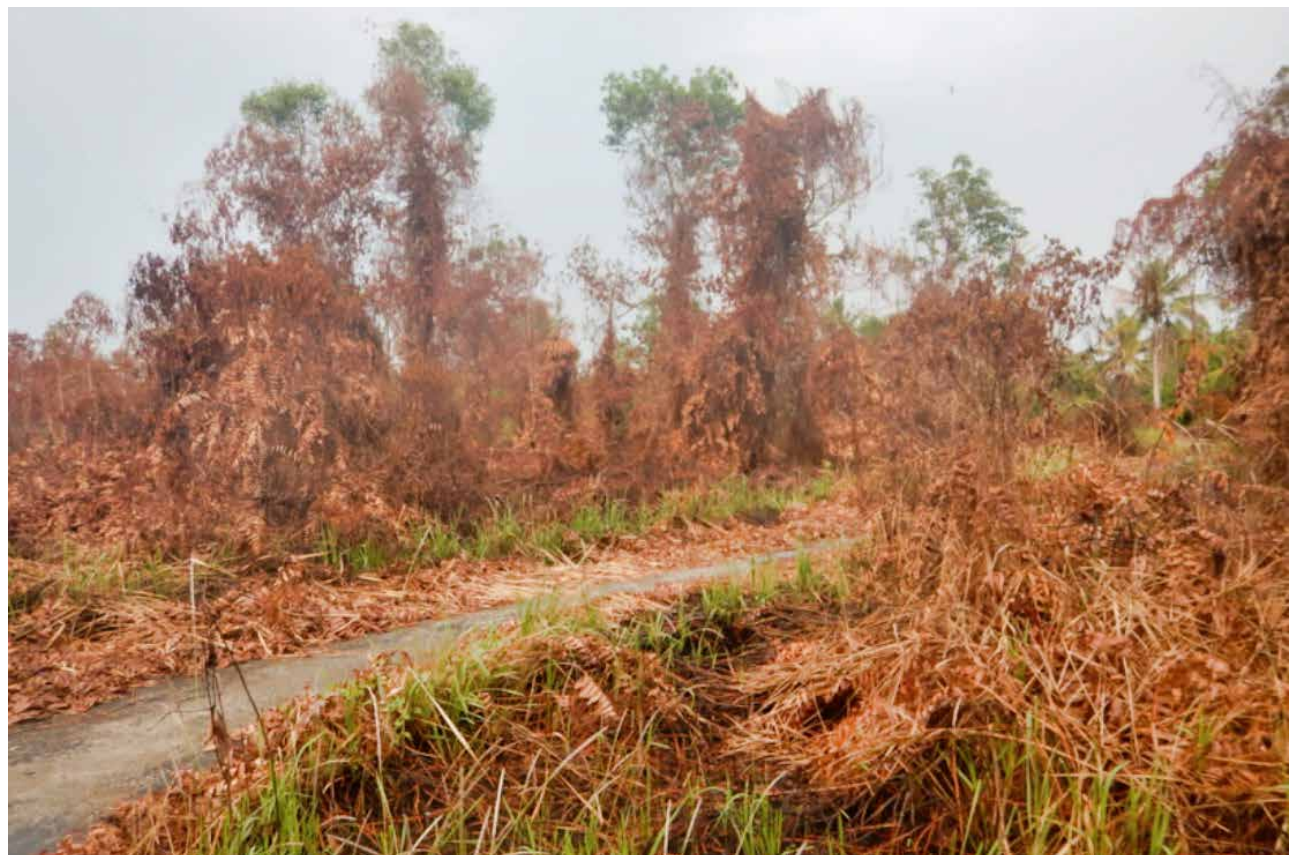

\section{Gambar 7.2 Daerah rawan kebakaran di Desa Dompas (foto oleh D. Puspitaloka/CIFOR)}


MPA di lima desa ini memahami dan mengkategorikan lahan-lahan yang memiliki sejarah kebakaran maupun kebakaran berulang, dan lahan kosong yang ditumbuhi semak belukar sebagai daerah rawan kebakaran (Gambar 7.2 sampai dengan Gambar 7.8). Jalur patroli pencegahan kebakaran hutan dan lahan diprioritaskan pada daerah-daerah tersebut. Saat musim kemarau panjang, MPA akan meningkatkan kesiapsiagaan melalui peningkatan frekuensi patroli pencegahan kebakaran. Namun jika kebakaran telah terjadi, terutama di lahan gambut, MPA membutuhkan waktu lebih lama untuk memadamkan kebakaran tersebut, bergantung pada tingkat ketebalan dan kerusakan pada gambut. Semakin lama dan sering kebakaran terjadi, maka dana operasional akan tergerus dan sering tidak mencukupi, terlebih mengingat banyaknya jumlah anggota yang diperlukan. Kelembagaan MPA perlu diperkuat dan diarahkan pada kemandirian melalui program-program pendukung, misalnya pembuatan dan implementasi model bisnis dalam rangka program pemberdayaan (dibahas pada bab terpisah dalam buku ini). Program-program pemberdayaan ini telah dilaksanakan oleh sebuah BUMN di Desa Sejangat dan Kelurahan Pakning Asal, dengan menggunakan pendekatan top-down dan pendampingan yang tidak intensif. Di Desa Sukajadi, kegiatan pemberdayaan dilakukan secara swadaya atas inisiatif MPA, namun sayangnya tidak ada pendampingan yang intensif. MPA Desa Dompas merupakan satu-satunya penerima manfaat langsung dari kegiatan uji coba lapangan yang dilakukan melalui riset aksi partisipatif, dengan pendekatan bottom-up dan pendampingan intensif.

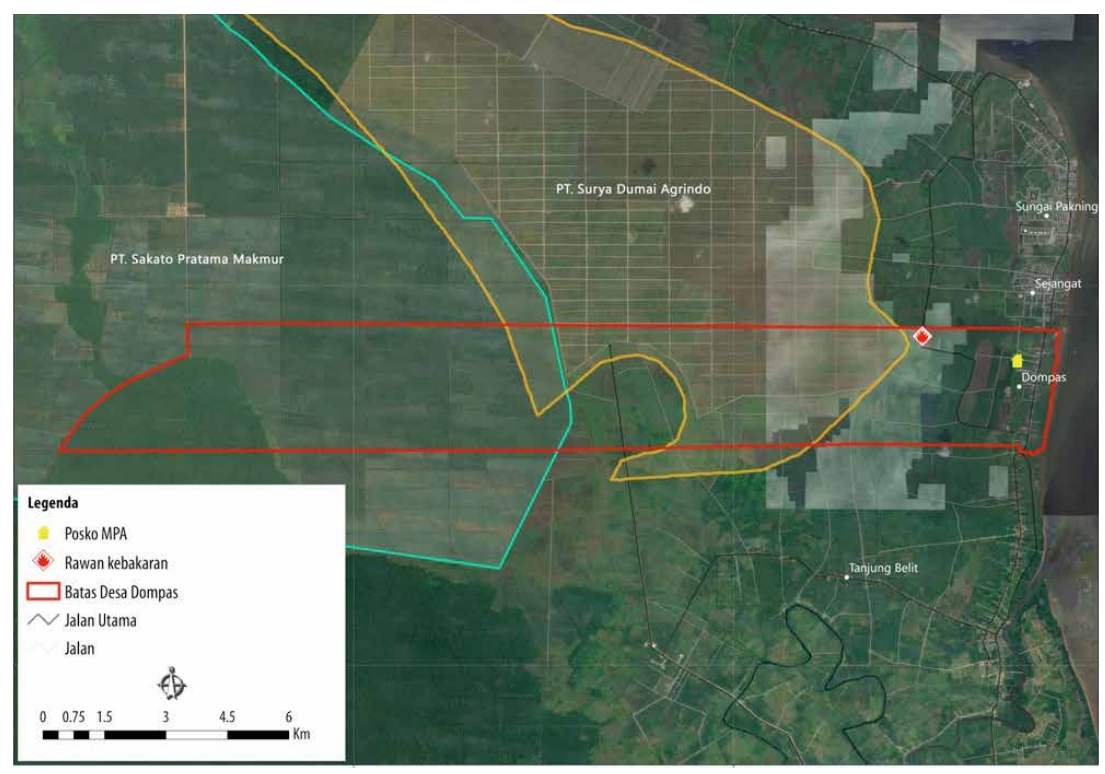

Gambar 7.3 Peta lokasi rawan kebakaran di Desa Dompas. 


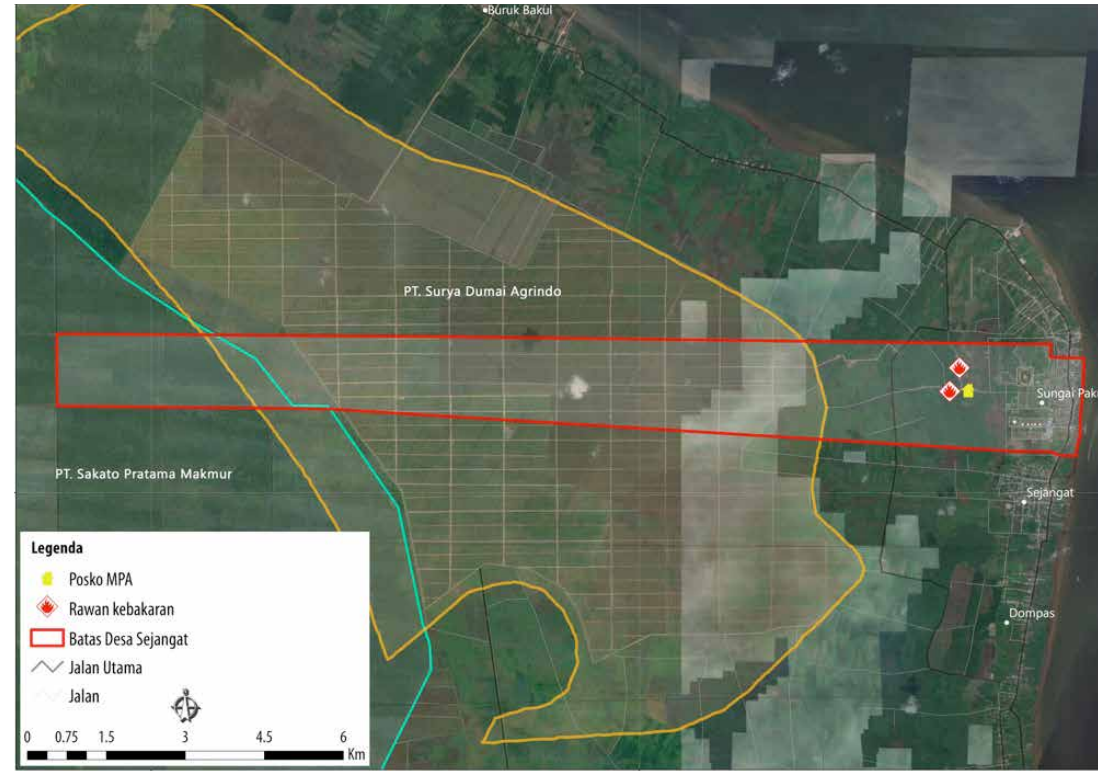

Gambar 7.4 Peta lokasi rawan kebakaran di Kelurahan Sungai Pakning.

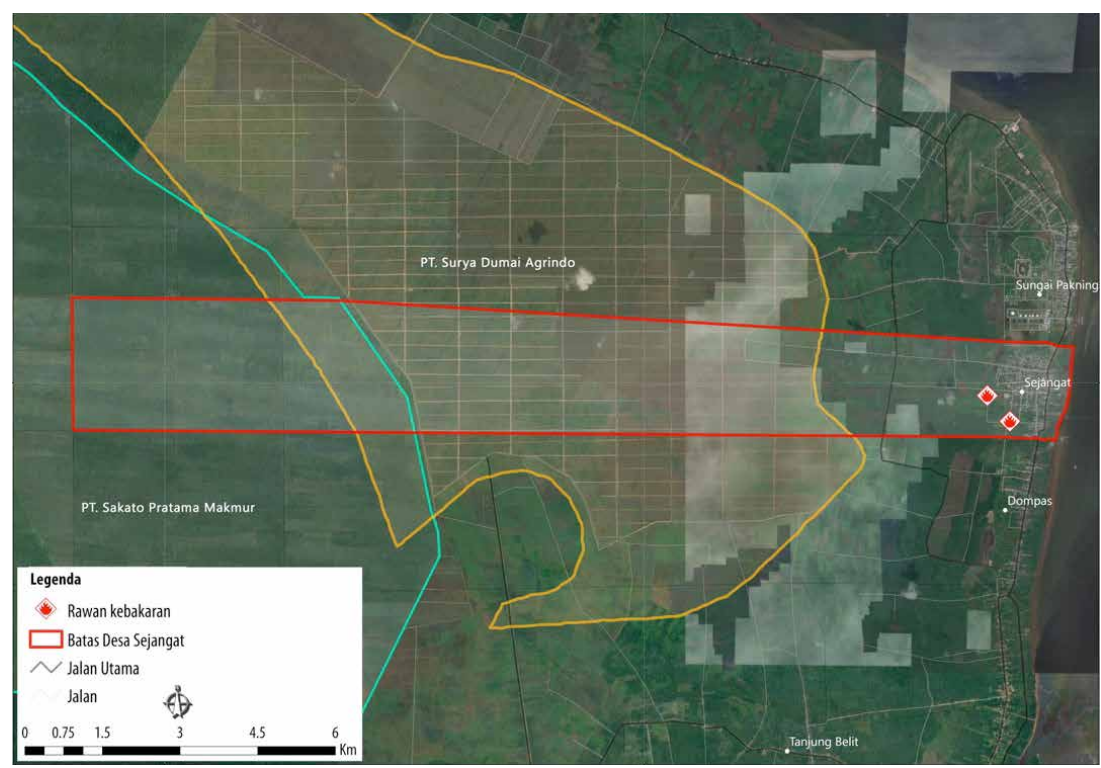

Gambar 7.5 Peta lokasi rawan kebakaran di Desa Sejangat. 


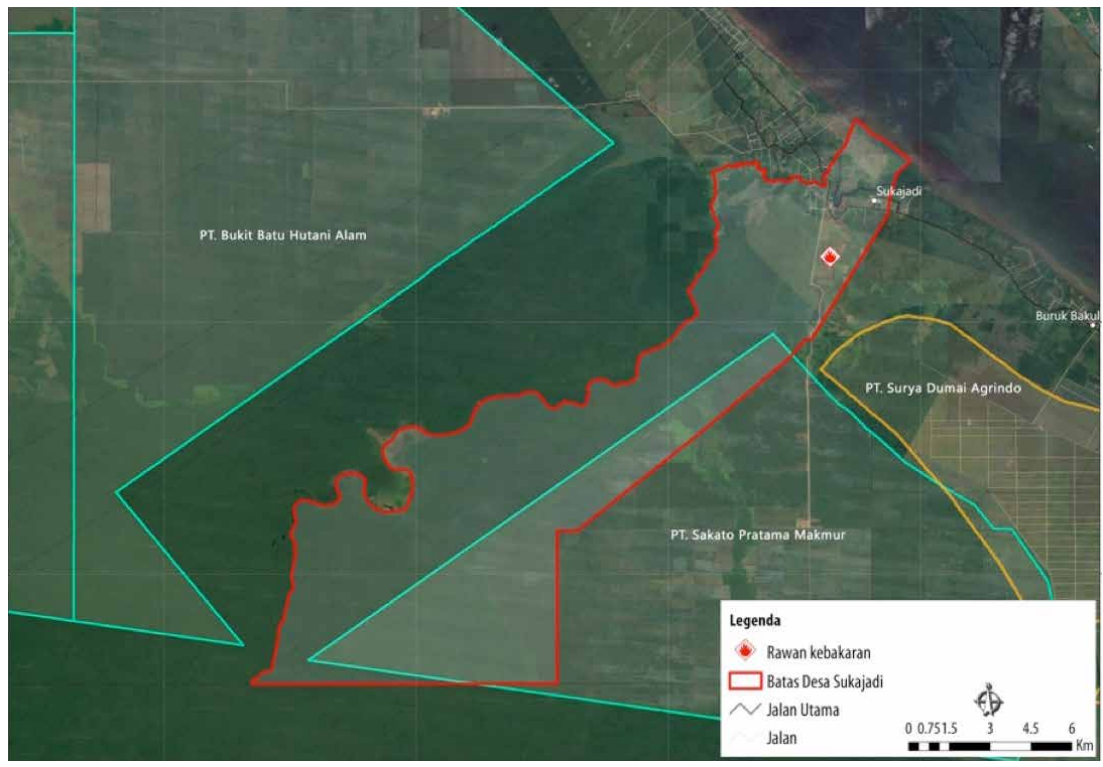

Gambar 7.6 Peta lokasi rawan kebakaran di Desa Sukajadi.

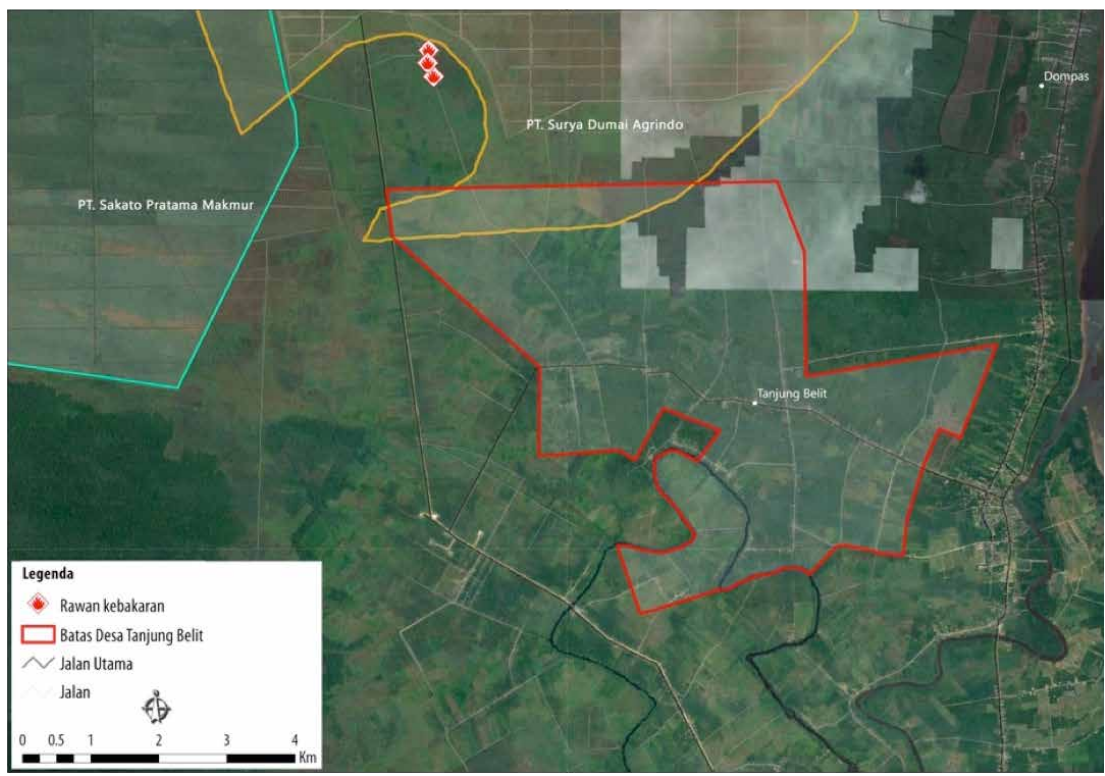

Gambar 7.7 Peta lokasi rawan kebakaran di Desa Tanjung Belit. 


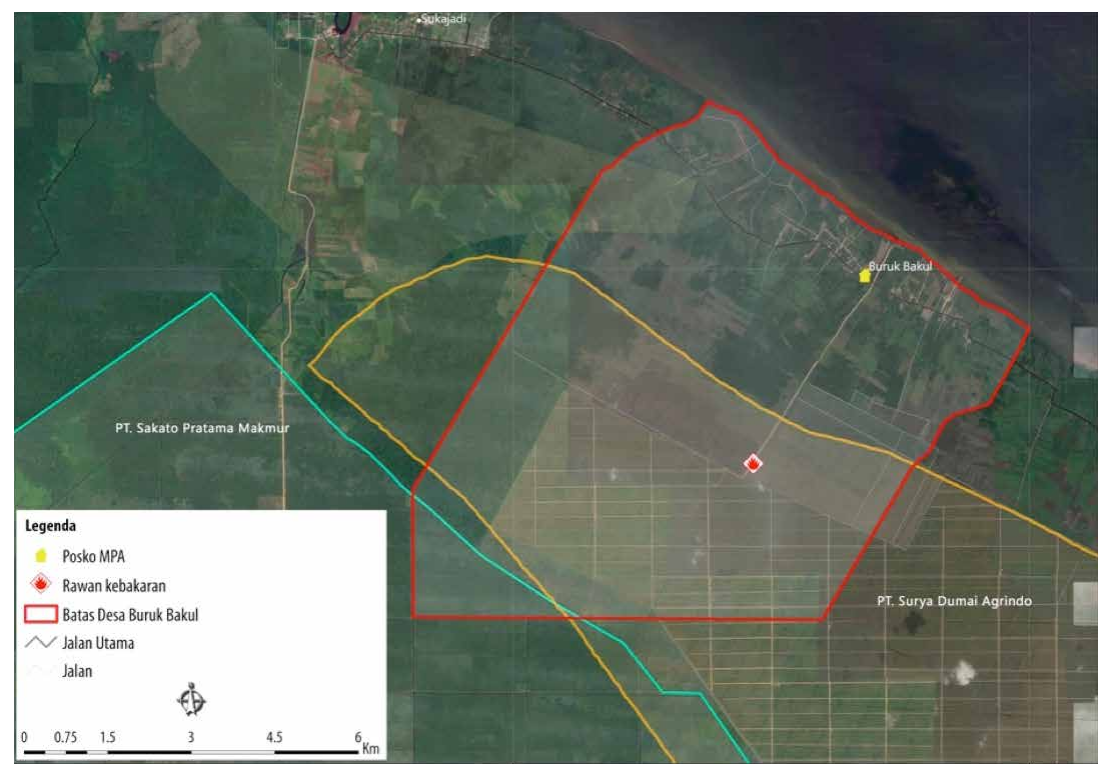

Gambar 7.8 Peta lokasi rawan kebakaran di Desa Buruk Bakul.

\subsubsection{Definisi, syarat pembentukan, struktur organisasi dan peran aktual Masyarakat Peduli Api}

MPA didefinisikan sebagai masyarakat yang secara sukarela peduli terhadap pengendalian kebakaran hutan dan lahan yang telah dilatih/diberi pembekalan serta dapat diberdayakan untuk membantu pengendalian kebakaran hutan (berdasarkan Peraturan Direktur Jenderal Perlindungan Hutan dan Konservasi Alam No. P.2/IVSET/2014). Pembentukan MPA dimulai dari penetapan desa sasaran yakni desa yang berbatasan dengan kawasan hutan dan rawan kebakaran oleh Kepala Unit atau Kesatuan Pengelolaan Hutan. Selanjutnya MPA dibentuk melalui tahapan perencanaan, pemenuhan persyaratan, pembekalan dan penetapan. Perencanaan pembentukan MPA diawali dengan kegiatan sosialisasi pada masyarakat desa sasaran dan calon anggota MPA. Untuk dapat bergabung menjadi anggota MPA, calon anggota yang dimaksud harus memenuhi beberapa persyaratan, termasuk mendaftar sebagai relawan dan mengikuti pembekalan pengendalian kebakaran. Jumlah MPA, mengacu pada Perdirjen di atas, paling tidak terdiri dari dua regu yang beranggotakan masingmasing 15 orang. Jika syarat-syarat tersebut sudah dipenuhi, maka akan dilaksanakan 
pembekalan oleh fasilitator dari Direktorat Pengendalian Kebakaran Hutan, UPT, atau lembaga terkait. Selanjutnya, MPA dan anggota-anggotanya ditetapkan dengan disertai pemberian kartu anggota, sertifikat lulus pembekalan, dan SK Bersama antara Kepala UPT atau KPH dan Camat. MPA berkedudukan di desa dan mendapat pembiayaan dari dana Anggaran Pendapatan dan Belanja Desa. Sebagai suatu lembaga, maka MPA mempunyai struktur organisasi yang mempunyai peran tertentu. Struktur organisasi MPA umumnya mempunyai perangkat organisasi dan tugas sebagai berikut:

- Ketua MPA : melaksanakan tugas perencanaan, pengorganisasian, operasional, pengawasan dan evaluasi dalam upaya pengendalian kebakaran lahan dan hutan (dalkarhutla) di desanya.

- Sekretaris : mengelola administrasi dan kesekretariatan.

- Bendahara : mengelola administrasi keuangan.

- Kepala Regu : melaksanakan tugas operasional dalkarhutla.

Pada awalnya, fungsi MPA berbasis desa seperti yang tercantum pada Peraturan Menteri Kehutanan No. P.12/Menhut-II/2009 tentang pengendalian kebakaran hutan yang diatur secara lebih rinci melalui Perdirjen Perlindungan Hutan dan Konservasi Alam No. P.2/IV-SET/2014 adalah sebagai kelompok relawan dalam pengendalian kebakaran lahan dan hutan, yang diharapkan memperoleh dukungan penuh secara kontinu dari berbagai pihak. MPA melaksanakan operasional kegiatan sesuai dengan yang sudah direncanakan oleh Manggala Agni/KPH/Kecamatan yang membawahi.

Namun demikian, setelah lima tahun implementasi dari kebijakan tersebut, ternyata asumsi awal yang digunakan tidak berjalan dengan baik. Untuk dapat berperan dan berfungsi sesuai harapan, MPA perlu ditingkatkan kemampuannya dan diberdayakan dalam berbagai aspek.

Dengan semakin kompleksnya permasalahan kebakaran hutan dan lahan, termasuk fungsi koordinasi penanganannya, maka peran aktual MPA dengan kondisi terkini diharapkan dapat:

1. Melakukan upaya pencegahan dan pemadaman dini dengan:

- Mengidentifikasi lokasi rawan kebakaran.

- Memantau dan merawat sekat-sekat kanal.

- Merencanakan dan membuat sumur bor/artesis untuk pembasahan dan penyediaan air.

- Memantau dan menjaga tinggi muka air pada saluran kanal.

- Merencanakan pembuatan sekat bakar.

- Melakukan patroli rutin. 
2. Melakukan usaha penanggulangan dampak kebakaran di wilayah desanya masingmasing dengan:

- Melakukan pemadaman ketika ditemukan lokasi kebakaran.

- Berkoordinasi dengan pihak-pihak terkait dalam upaya memadamkan kebakaran.

3. Melaksanakan tugas penyelamatan dalam keadaan darurat saat kebakaran, dan membantu MPA lainnya jika dibutuhkan:

- Melakukan perencanaan tindakan untuk mencegah api menjalar lebih luas.

- Membantu MPA pada desa lainnya untuk pemadaman kebakaran.

- Membantu Manggala Agni dalam memadamkan kebakaran hutan.

4. Bekerja sama dan berkoordinasi dengan instansi atau lembaga lain, misalnya: MPA desa lain, Damkar, Dinas Lingkungan Hidup, KPH, BPBD, Manggala Agni.

5. Melakukan penelitian dan pengembangan ilmu pengetahuan dan teknologi dalam bidang kebakaran.

6. Mengembangkan teknologi informasi (misalnya internet, penggunaan teknologi Global Positioning System/GPS dan pemetaan):

- Mengumpulkan data hidrologi.

- Mengumpulkan data tanaman.

- Mengumpulkan data kebakaran.

7. Menyelenggarakan program pendidikan dan pelatihan bagi masyarakat:

- Sosialisasi tentang pencegahan kebakaran melalui pembukaan lahan tanpa api di lingkungan desa.

- Merekrut relawan ditingkat desa.

- Melakukan penyegaran kepada sesama anggota MPA.

8. Memfasilitasi pembuatan peraturan desa dan mensosialisasikan kepada masyarakat.

9. Mengelola dan mengusahakan dana untuk biaya operasional MPA melalui:

- Mengelola dana yang bersumber dari APBDes dan membuat pelaporan.

- Mengupayakan bantuan dana operasional dari sponsor.

- Mengupayakan dana MPA dari usaha mandiri.

\subsubsection{Menuju MPA yang berdaya}

Berdasarkan diskusi kelompok terarah (FGD) dengan MPA dari lima desa di Kecamatan Bukit Batu dan Siak Kecil, Kabupaten Bengkalis yang juga melibatkan Manggala Agni Daops Siak, berdaya didefinisikan sebagai optimalnya fungsi dari setiap struktur yang ada di MPA. Dengan demikian, peran dan tugas MPA perlu dideskripsikan secara bersama dan terinci, dan prosedur operasi standar (SOP) perlu disusun untuk memandu praktik-praktik pencegahan dan pemadaman kebakaran hutan dan lahan, serta pengurusan administrasi dan pelaporan. 


\section{a. Peran dan tugas}

1. Ketua MPA

- Memimpin dan bertanggung jawab terhadap jalannya organisasi.

- Menyusun rencana kerja tahunan kegiatan pengendalian kebakaran.

- Melakukan kerjasama dengan pihak lain dalam kegiatan pengendalian kebakaran hutan dan lahan.

- Membuat laporan evaluasi pengendalian kebakaran hutan dan lahan.

- Mengkomunikasikan hasil-hasil kegiatannya dengan pihak-pihak terkait.

2. Bendahara

- Bekerjasama dengan ketua mencari dukungan dana.

- Mengatur dan mengelola keuangan organisasi.

- Membuat pembukuan keuangan.

3. Sekretaris

- Mewakili ketua jika berhalangan.

- Melakukan kegiatan administrasi.

- Membuat catatan pertemuan dan mendokumentasikan kegiatan organisasi.

4. Seksi Logistik

- Mengkoordinir penyediaan konsumsi dan akomodasi pada setiap kegiatan.

- Mengkoordinir penyediaan peralatan, sarana dan prasarana dalam operasi pemadaman.

- Merawat sarana dan prasarana pemadam kebakaran.

5. Ketua Regu

- Melaksanakan program dan arahan dari ketua.

- Melaksanakan tugas operasional dalkarhutla.

- Mengkoordinir kegiatan pencegahan, pemadaman dan pascakebakaran.

- Mengatur persiapan dan strategi pemadaman.

6. Pengarah/ Pembimbing

- LSM: sebagai fasilitator, memberikan arahan, bimbingan serta pelatihan dalam kegiatan dalkarhutla.

- Instansi dan dinas terkait: memberikan arahan, bimbingan dan pelatihan dalam kegiatan pengendalian kebakaran hutan dan lahan serta memberikan dukungan dana, sarana dan prasarana kegiatan pengendalian kebakaran hutan dan lahan. 


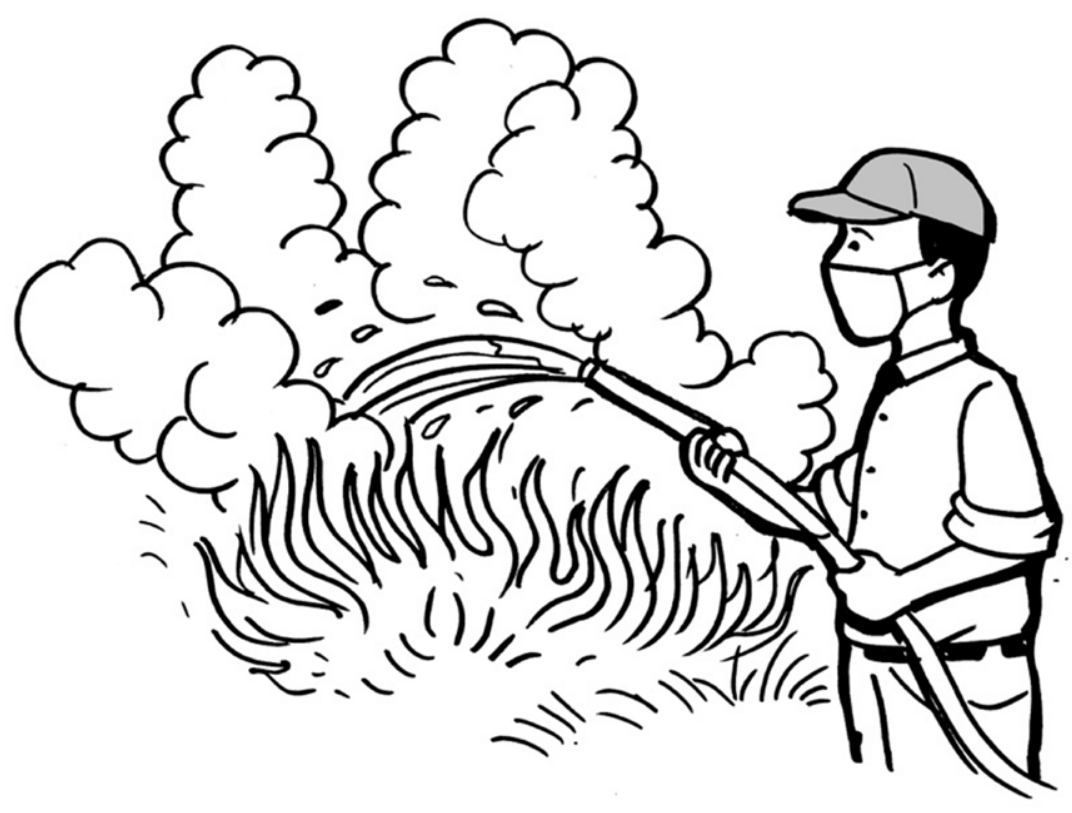

Gambar 7.9 MPA memiliki peranan dalam pemadaman kebakaran dini

b. Prosedur operasi standar pengendalian kebakaran hutan dan lahan MPA

Prosedur operasi standar (SOP) berisi seperangkat instruksi, yaitu langkah demi langkah dalam upaya pengendalian kebakaran hutan dan lahan yang dilakukan anggota relawan MPA secara rutin dan bersinergi dalam mencapai tujuan yang telah ditetapkan (Gambar 7.10). SOP bertujuan untuk meningkatkan efisiensi hasil kegiatan, mengoptimalkan kinerja, dan untuk menghindari miskomunikasi antar relawan yang dapat mengakibatkan kegagalan operasional pengendalian kebakaran hutan dan lahan. 


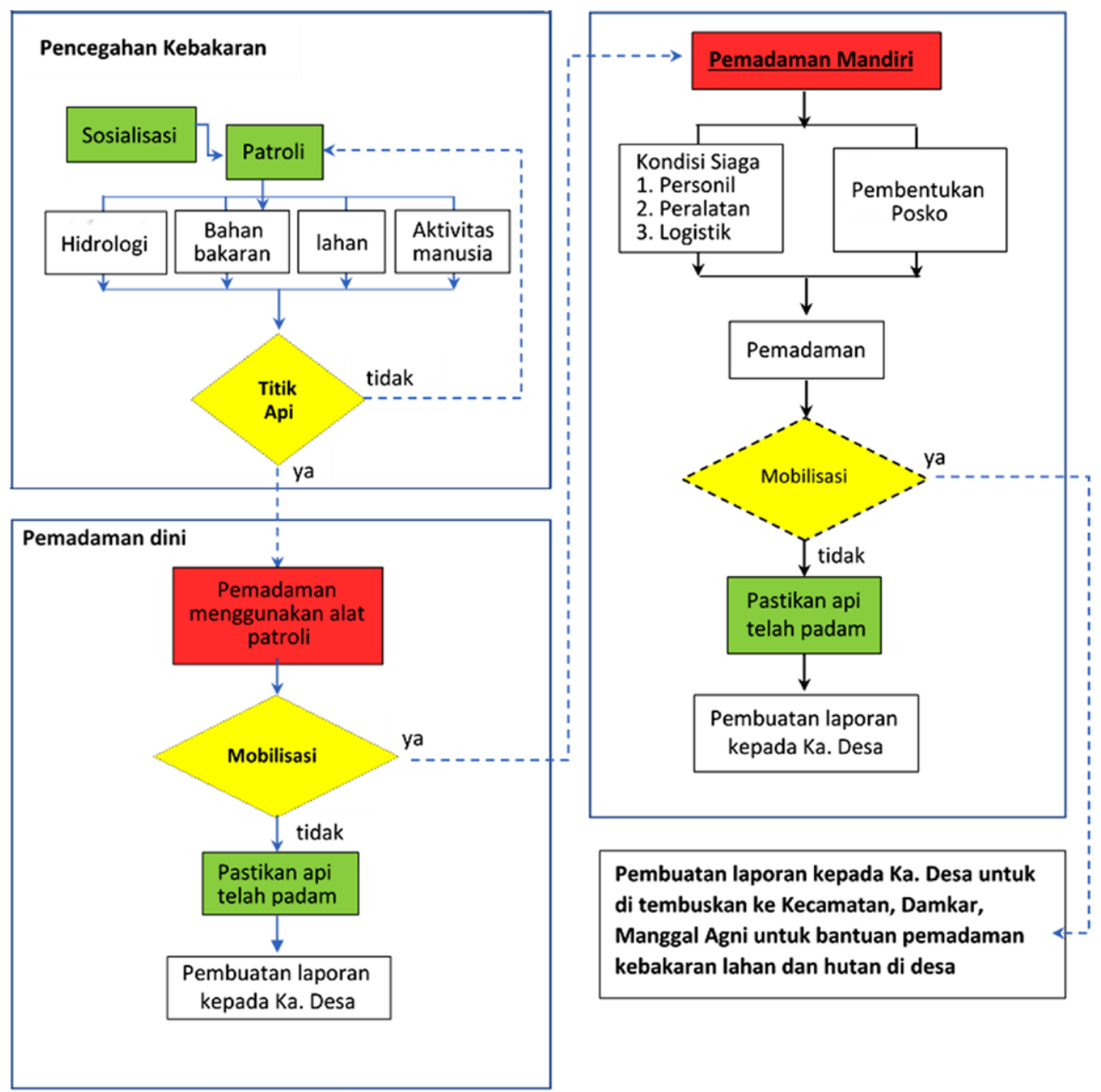

Gambar 7.10 Prosedur MPA dalam pengendalian kebakaran hutan dan lahan. 


\section{c. Rencana kerja MPA dan daftar periksa (checklist) pelaksanaan}

Rencana kerja disusun setiap bulan untuk keseluruhan operasional MPA agar setiap fungsi mengetahui apa yang perlu dilakukan, jenis dan waktunya. Selain itu, ketua juga melakukan pemantauan hasil pelaksanaan kegiatan dan membuat kesimpulan, untuk selanjutnya dilaporkan ke Kepala Desa dan lembaga terkait lainnya. Setiap kegiatan yang dilakukan oleh pelaksana dibuat laporannya dan diserahkan kepada MPA untuk direkapitulasi pada setiap akhir bulan dan dilaporkan kepada Kepala Desa. Tabel 7.1 dan 7.2 masing-masing merupakan acuan pelaporan rencana dan hasil kegiatan MPA.

\section{Tabel 7.1 Lembar rencana kegiatan MPA.}

\section{Lembar Rencana Kegiatan MPA \\ Desa... pada bulan... tahun ...}

\begin{tabular}{|c|c|c|c|c|}
\hline Waktu Kegiatan & Jenis Kegiatan & Pelaksana & Jumlah Biaya & Catatan \\
\hline & 1. Sosialisasi & & & \\
\hline & 2. Patroli & & & \\
\hline & $\begin{array}{l}\text { 3. Pemeliharaan } \\
\text { dan pembuatan } \\
\text { infrastruktur dan } \\
\text { peralatan dalkarhutla: } \\
\text { a. sumur pantau } \\
\text { b. sekat bakar } \\
\text { c. sekat kanal } \\
\text { d. kendaraan } \\
\text { e. peralatan } \\
\text { pemadaman }\end{array}$ & & & \\
\hline & $\begin{array}{l}\text { 4.Pemadaman } \\
\text { Kebakaran }\end{array}$ & & & \\
\hline
\end{tabular}

Tanggal, ...

Dibuat oleh

Disetujui oleh

Ketua MPA

Kepala Desa 
Tabel 7.2 Lembar laporan hasil kegiatan MPA.

\begin{tabular}{|c|c|c|c|c|c|}
\hline \multicolumn{6}{|c|}{$\begin{array}{c}\text { Lembar Laporan Hasil Kegiatan MPA } \\
\text { Desa... pada bulan... tahun ... }\end{array}$} \\
\hline \multirow[t]{5}{*}{$\begin{array}{c}\text { Waktu } \\
\text { Kegiatan }\end{array}$} & Jenis Kegiatan & Pelaksana & Jumlah Biaya & Catatan & $\begin{array}{c}\text { Hasil } \\
\text { Pelaksanaan }\end{array}$ \\
\hline & 1. Sosialisasi & & & & \\
\hline & 2. Patroli & & & & \\
\hline & $\begin{array}{l}\text { 3. Pemeliharaan } \\
\text { dan pembuatan } \\
\text { infrastruktur } \\
\text { dan peralatan } \\
\text { dalkarhutla: } \\
\text { a. sumur pantau } \\
\text { b. sekat bakar } \\
\text { c. kanal bloking } \\
\text { d. kendaraan } \\
\text { e. peralatan } \\
\text { pemadaman }\end{array}$ & & & & \\
\hline & $\begin{array}{l}\text { 4. Pemadaman } \\
\text { Kebakaran }\end{array}$ & & & & \\
\hline \multicolumn{6}{|c|}{ Kesimpulan evaluasi aktivitas bulanan: } \\
\hline \multicolumn{6}{|l|}{1.} \\
\hline \multicolumn{6}{|l|}{ 2. $\quad \ldots$} \\
\hline \multicolumn{6}{|l|}{ 3. $\quad \ldots$} \\
\hline \multicolumn{6}{|c|}{ Rekomendasi: } \\
\hline$\ldots$ & \multicolumn{5}{|c|}{$\ldots$} \\
\hline$\ldots$ & \multicolumn{5}{|c|}{$\ldots$} \\
\hline & \\
\hline \multicolumn{6}{|l|}{ Tanggal, ... } \\
\hline \multicolumn{6}{|l|}{$\begin{array}{l}\text { Dibuat oleh } \\
\text { oleh }\end{array}$} \\
\hline Ketua MPA & & & & & Kepala Desa \\
\hline
\end{tabular}




\section{d. Sosialisasi dan rekrutmen anggota baru}

Kegiatan sosialisasi ditujukan untuk meningkatkan kesadaran dan kepedulian masyarakat tentang bahaya kebakaran hutan dan lahan. Selain itu sosialisasi juga ditujukan untuk merekrut anggota baru MPA. Dengan semakin banyak jumlah anggota, diharapkan akan semakin banyak masyarakat yang membantu MPA dalam menjalankan perannya. Setiap sosialisasi diharapkan menghasilkan kesepakatan tentang langkahlangkah yang akan dilakukan dalam penanganan kebakaran dan kegiatan terkait lainnya dengan warga masyarakat. Tabel 7.3 merupakan acuan dalam pembuatan berita acara sosialisasi dan Tabel 7.4 adalah surat pernyataan sebagai anggota baru MPA yang diadopsi dari Perdirjen PHKA No. P-2/IV-SET/2014 yang kemudian diperbarui oleh Peraturan Direktur Jenderal Perubahan Perubahan Iklim P3/2018.

\section{Tabel 7.3 Format berita acara sosialisasi.}

\section{Berita Acara Sosialisasi}

Pada tanggal... bulan... tahun..., MPA Desa ... telah melakukan sosialisasi pencegahan dan penanggulangan kebakaran pada warga masyarakat yang terkait pada lahan rawan kebakaran pada lokasi ...

Sosialisasi tersebut dilakukan berlangsung secara dinamis dan dilakukan diskusi antara warga masyarakat dan MPA dan Pemerintah Desa. Kesepakatan yang berhasil dibangun adalah:

1. ...

2. $\ldots$

3. ...

Demikian berita acara ini dibuat untuk mendukung desa yang aman dan terhindar dari bahaya kebakaran

Tanggal, ...

Dibuat oleh

\section{Ketua MPA}

Lampiran:

1. Daftar nama warga pemilik lahan,

2. Daftar nama warga disekitar lokasi rawan kebakaran. 
Tabel 7.4 Formulir pendaftaran anggota baru.

\section{Formulir Pendaftaran Anggota Baru MPA Desa ...}

Nama

Warga Negara

Pekerjaan

Alamat Lengkap :

No. telepon

Dengan ini mengajukan permohonan menjadi anggota baru MPA Desa ..., Kecamatan ..., Kabupaten..., Provinsi ... Bersedia melaksanakan tugas dan kewajiban MPA secara mandiri atau kelompok dan bekerja bersama dengan instansi terkait dalam kegiatan pencegahan, pemadaman, dan penanganan paska kebakaran.

Demikian, surat pernyataan ini dibuat dengan sebenar-benarnya.

Tanggal, ...

Materai Rp 6.000,-

(Nama lengkap pemohon) 


\section{e. Patroli}

Selain dipengaruhi oleh iklim, misalnya El-Niño, kebakaran hutan dan lahan juga disebabkan oleh kondisi lanskap yang terdegradasi dan aktivitas manusia. Oleh karena itu, kondisi lanskap yang berpotensi memudahkan terjadinya kebakaran perlu diidentifikasi. Beberapa ciri kondisi lanskap yang rawan kebakaran adalah lanskap yang sudah rusak (ditandai dengan kondisi terbuka dan dominasi semak belukar) dan sejarah kebakaran pernah/sering terjadi pada area tersebut. Faktor manusia juga dapat memicu terjadinya kebakaran, baik karena kelalaian maupun kesengajaan. Dengan demikian, warga masyarakat perlu ditingkatkan kewaspadaan dan kesadarannya terhadap perilaku-perilaku yang berisiko menyebabkan kebakaran. Mengingat hal tersebut maka patroli perlu diarahkan untuk dapat sekaligus mengidentifikasi faktorfaktor pemungkin yang berkontribusi menyebabkan kebakaran. Laporan patroli secara berkala idealnya melaporkan informasi seperti pada format tabel laporan dibawah (Tabel 7.5).

Tabel 7.5 Laporan patroli pencegahan kebakaran hutan dan lahan.

\section{Laporan Patroli Pencegahan Kebakaran Hutan dan Lahan \\ Desa ...}

Nama Relawan Patroli:

1....

2. ...

\begin{tabular}{|l|c|c|c|c|c|c|}
\hline \multirow{2}{*}{$\begin{array}{c}\text { Lokasi/ } \\
\text { koordinat }\end{array}$} & $\begin{array}{c}\text { Tumpukan } \\
\text { bahan } \\
\text { bakaran }\end{array}$ & $\begin{array}{c}\text { Kondisi } \\
\text { kekeringan }\end{array}$ & $\begin{array}{c}\text { Kelembaban } \\
\text { lahan }\end{array}$ & $\begin{array}{c}\text { Tinggi } \\
\text { muka air } \\
\text { tanah }\end{array}$ & $\begin{array}{c}\text { Jarak } \\
\text { sumber air } \\
\text { terdekat }\end{array}$ & $\begin{array}{c}\text { Penilaian } \\
\text { tindakan } \\
\text { yg perlu } \\
\text { dilakukan }\end{array}$ \\
\hline Rawan 1 & & & & & & \\
\hline Rawan 2 & & & & & & \\
\hline Rawan 3 & & & & & & \\
\hline ...dst... & & & & & & \\
\hline
\end{tabular}

Tanggal, ...

Dibuat oleh,

\section{Relawan patroli}




\section{e. Pembuatan dan pemeliharaan sekat kanal dan sumur pantau}

Salah satu faktor pemicu kebakaran lahan dan hutan yang parah adalah rusaknya kondisi hidrologi, khususnya pada tanah bergambut. Untuk itu, dalam kegiatannya MPA perlu memantau kondisi sekat kanal yang ada dan juga mengusulkan untuk memperbaiki kondisi hidrologi dengan membuat sekat kanal baru dan sekat bakar. Kegiatan ini utamanya dilakukan pada lokasi-lokasi yang rawan kebakaran. Tabel 7.6 menjelaskan lebih rinci laporan usulan pembuatan dan pemeliharaan sekat kanal.

Tabel 7.6 Laporan usulan pembuatan dan pemeliharaan sekat kanal.

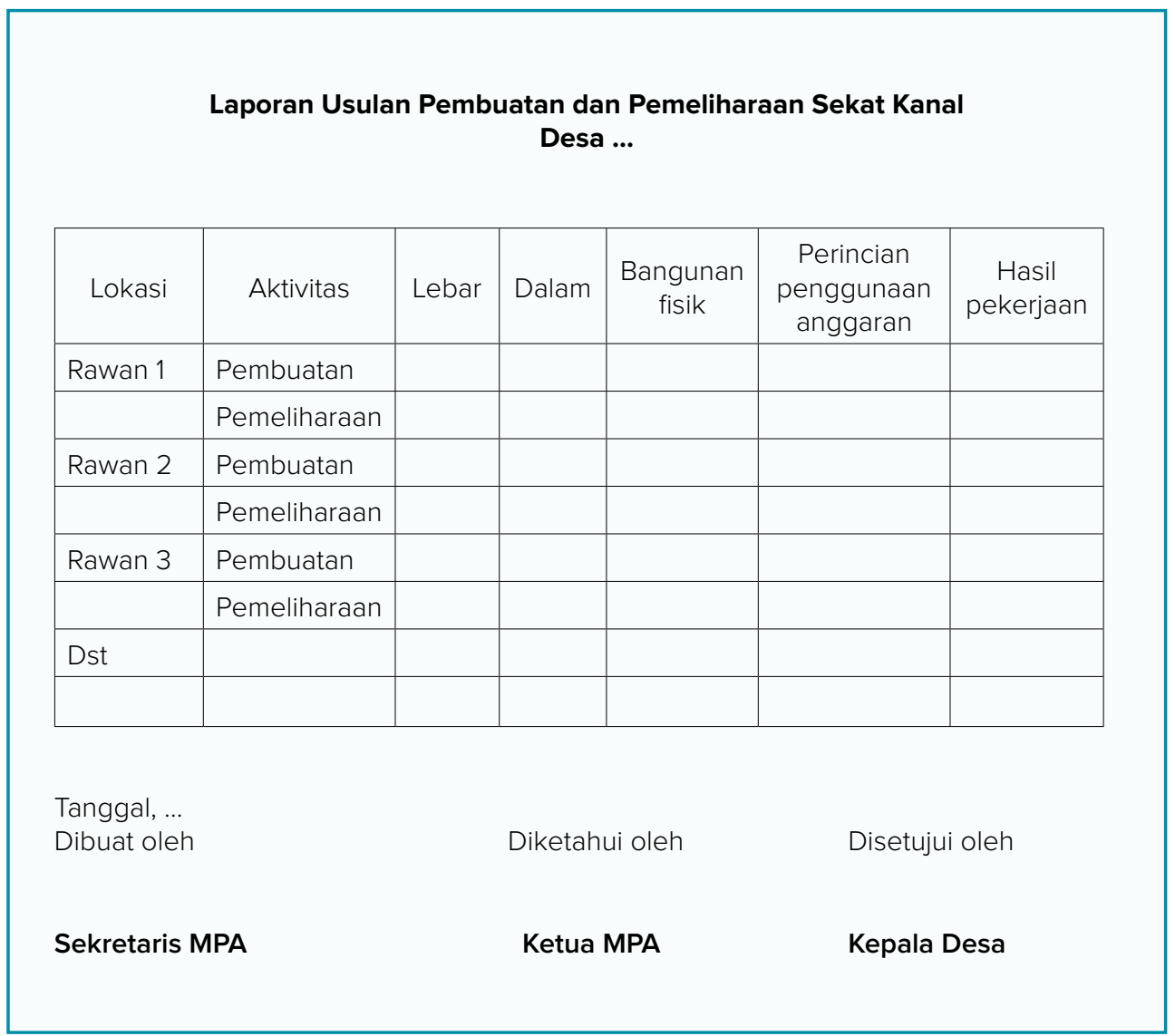




\section{f. Siaga pemadaman kebakaran}

Berdasarkan hasil analisa terhadap kondisi keadaan alam yang memungkinkan terjadinya potensi kebakaran, MPA akan melaporkan kepada Kepala Desa untuk memutuskan tindakan siap siaga. Selanjutnya MPA bersama-sama dengan aparatur desa melakukan sosialisasi kepada warga masyarakat, serta mengambil tindakan dan langkah-langkah untuk mempersiapkan personel, peralatan, logistik dan sumber daya pengendalian kebakaran hutan dan lahan untuk menghadapi kejadian kebakaran. Berbagai bentuk kesiagaan yang dimaksud adalah:

\section{a. Siaga personel}

- Lakukan analisa ketersediaan dan kebutuhan personel pada masing-masing wilayah kerja.

- Siapkan personel regu pemadaman pada masing-masing wilayah kerja, yang jumlah personel setiap regunya disesuaikan dengan ketersediaan personel.

- Lakukan penyusunan jadwal kegiatan masing-masing regu dalam rangka siaga pemadaman kebakaran.

\section{b. Siaga peralatan}

- Lakukan permeriksaan kesiapan sarana transportasi, peralatan pemadaman, peralatan dokumentasi untuk keperluan masing-masing regu.

- Siapkan peralatan untuk masing-masing regu.

- Siapkan buku kendali penggunaan setiap sarana dan peralatan oleh masingmasing regu.

- Siapkan kebutuhan operasional masing-masing regu:

\section{c. Peralatan tangan}

- Parang/golok, kapak, kapak

- Sekop, cangkul, garu cangkul, garu tajam, kepyok (flapper)

- Pompa punggung

\section{d. Pompa dan kelengkapannya}

- Pompa pemadam induk (fixed pump)

- Pompa pemadam jinjing (portable pump)

- Selang hisap, selang kirim, nozzle, cabang penyambung selang (Y connector), adaptor coupling, direct valve, dan tempat air portabel (collapsible tank)

\section{e. Sarana transportasi dan pemadaman}

- Motor dan gerobak untuk mengangkut peralatan pemadaman

- Bahan bakar mesin untuk kendaraan dan pompa 


\section{f. Siaga logistik}

- Siapkan bahan makanan dan minuman dengan mempertimbangkan lama pemadaman.

- Siapkan obat-obatan dan peralatan P3K.

\section{g. Prosedur pemadaman dini kebakaran}

\section{Pemadaman dini}

- Lakukan "scene size-up" lokasi kebakaran. Beberapa langkah-langkah penting dalam "scene size-up" adalah sebagai berikut23.

- Kumpulkan data di lapangan

- Nilai keadaan bahaya

- Tentukan sumber daya

- Tentukan prioritas aksi

- Kembangkan rencana aksi

- Laksanakan aksi

- Evaluasi kemajuan kegiatan

- Lakukan pemadaman dini dengan menyebarkan tanah secara langsung ke sumber api atau memendam benda yang terbakar ke dalam tanah dengan menggunakan sekop, cangkul, dan lain sebagainya.

- Pukul dan tarik sumber api, sambil menggentarkan bahan bakar yang sedang terbakar, dengan menggunakan kepyok (flapper), sekop, atau ranting pohon.

- Semprotkan/siramkan air ke arah api dengan menggunakan pompa punggung dan atau pompa jinjing dan atau pompa apung.

- Lakukan mopping up (sapu bersih api) untuk memastikan api benar-benar padam.

- Apabila api telah padam, lakukan evaluasi secara menyeluruh dan laporkan hasil kegiatan pemadaman kebakaran.

- Apabila api tidak dapat dipadamkan, lakukan permintaan bantuan ke Damkar ataupun Manggala Agni Daops terdekat melalui Kepala Desa, sambil melokalisir perambatan api dengan menjauhkan bahan bakaran yang belum terbakar. Informasikan kondisi aktual apa yang sudah dilakukan dan potensi perambatan kebakaran yang lebih luas.

\section{Teknik pemadaman langsung}

- Lakukan pengamatan secara cepat dan menyeluruh terkait kondisi api dan angin.

- Sebarkan tanah basah secara langsung ke sumber api.

- Rendam benda terbakar ke dalam tanah dengan menggunakan sekop dan cangkul.

23 https://sarunpad.wordpress.com/2011/04/22/penyelenggaraan-sar-dalam-bencana/ 
- Semprotkan air ke arah api.

- Gunakan suntikan gambut untuk pemadaman api bawah sedalam batas tinggi muka air.

- Semprotkan hingga gambut menjadi jenuh dan padatkan gambut tersebut.

- Pukul dan tarik bahan terbakar dengan menggunakan kopyok, sekop ataupun ranting pohon.

- Apabila api tidak terlalu besar dan hembusan angin tidak terlalu kencang, lakukan pemadaman langsung dari bagian kepala api terlebih dahulu.

- Setelah padam, lakukan evaluasi dan laporkan kepada Kepala Desa. Apabila dinilai sudah tidak mampu melakukan pemadaman, laporkan segera kepada Kepala Desa untuk meminta bantuan Damkar dan Manggala Agni Daops terdekat untuk memadamkan kebakaran.

\section{h. Pemeliharaan peralatan}

\section{- Kendaraan}

- Kendaraan perlu diparkir di sekretariat oleh relawan yang telah menyelesaikan patroli/kegiatan,. kemudian relawan membuat laporan kepada anggota regu yang akan melakukan patroli pada hari berikutnya.

- Kondisi kendaraan harus selalu dalam keadaan baik, oleh karena itu perlu dilakukan servis rutin (bulanan) dan pergantian suku cadang yang telah rusak.

\section{- Alat-alat tangan}

- Alat-alat yang dimaksud adalah: kopyok, sekop, cangkul, kapak, ember dan pompa tanki gendong.

- Apabila jumlahnya cukup untuk setiap anggota MPA, maka alat-alat ini dapat disimpan oleh masing-masing anggota. Jika tidak mencukupi jumlahnya untuk setiap anggota, maka peralatan tersebut disimpan di gudang perlengkapan.

\section{- Pompa air}

- Sebaiknya disimpan di gudang penyimpanan peralatan yang berada di sekretariat MPA.

- Apabila tidak digunakan dalam jangka waktu yang lama, sebaiknya setiap minggu alat-alat pompa perlu dihidupkan sekitar 10 menit dalam setiap harinya.

- Bahan bakar pompa di dalam tanki minimal harus tersedia 3/4 dari volume tanki.

- Selama mesin pompa digunakan, pastikan bunyi mesin normal dan alat beroperasi dengan baik, tidak ada kebocoran air, oli, dan bahan bakar.

- Setelah mesin pompa digunakan, pastikan semua peralatan yang digunakan tetap lengkap dan tidak ada yang hilang/kurang.

- Pastikan bagian pompa tidak ada yang kendor atau retak/rusak.

- Bersihkan mesin pompa dan simpan dengan baik di gudang penyimpanan

- Laporkan keadaan mesin pompa kepada sekretaris atau urusan logistik. 
Tabel 7.7 Formulir pemeriksaan mingguan mesin pompa air.

\section{Formulir Pemeriksaan Mingguan Mesin Pompa Air MPA Desa ... Minggu ke- ..., Bulan ..., Tahun ...}

No. label inventaris:

Jenis mesin pompa air:

Merek mesin pompa air:

\begin{tabular}{|c|c|c|c|}
\hline No & Bagian yang diperiksa & Hasil pemeriksaan & Keterangan \\
\hline 1 & Kondisi oli mesin & & \\
\hline 2 & Kondisi bahan bakar & & \\
\hline 3 & Kapan ganti oli terakhir & & \\
\hline 4 & Kondisi kebersihan mesin & & \\
\hline 5 & $\begin{array}{l}\text { Selama mesin pompa beroperasi } \\
\text { apakah terdapat kebocoran }\end{array}$ & & \\
\hline 6 & $\begin{array}{l}\text { Setelah mesin beroperasi adakah } \\
\text { terdapat suara yg tidak normal }\end{array}$ & & \\
\hline 7 & $\begin{array}{l}\text { Setelah mesin beroperasi adakah } \\
\text { kebocoran }\end{array}$ & & \\
\hline 8 & Selang & & \\
\hline & a. Hisap & & \\
\hline & b. Hantar & & \\
\hline & c. Nozzle & & \\
\hline
\end{tabular}

Tanggal, ...

Diperiksa oleh

Diketahui oleh

Logistik

Ketua MPA 
Tabel 7.8 Formulir pemeriksaan mingguan kendaraan operasional.

\section{Formulir Pemeriksaan Mingguan Kendaraan Operasional MPA Desa ...} Minggu ke-..., Bulan ..., Tahun ...

No. label inventaris:

Jenis kendaraan bermotor:

Merek kendaraan bermotor:

\begin{tabular}{|c|l|c|c|}
\hline No & Bagian yang diperiksa & Hasil pemeriksaan & Keterangan \\
\hline 1 & Kondisi oli mesin & & \\
\hline 2 & Kondisi bahan bakar & & \\
\hline 3 & Kapan ganti oli terakhir & & \\
\hline 4 & Kapan terakhir servis rutin & \\
\hline 5 & $\begin{array}{l}\text { Selama mesin pompa beroperasi } \\
\text { apakah terdapat kebocoran }\end{array}$ & & \\
\hline 6 & $\begin{array}{l}\text { Setelah mesin beroperasi adakah } \\
\text { terdapat suara yang tidak normal }\end{array}$ & & \\
\hline 7 & $\begin{array}{l}\text { Setelah mesin beroperasi adakah } \\
\text { kebocoran }\end{array}$ & & \\
\hline 8 & Rem & & \\
\hline 9 & Ban & & \\
\hline 10 & Lampu-lampu & & \\
\hline
\end{tabular}

Lainnya, ...

Tanggal, ...

Diperiksa oleh Diketahui oleh 


\section{i. Prosedur pelabelan dan peminjaman alat}

Tujuan prosedur pelabelan dan peminjaman alat adalah untuk inventarisasi alat dan untuk memberikan arahan tentang cara mengoperasikan alat-alat tertentu, mengingat beberapa alat memerlukan perhatian khusus dalam mengoperasikannya. Langkahlangkah yang perlu diterapkan dalam pelabelan dan peminjaman alat ini adalah sebagai berikut:

- Untuk pelabelan, registrasi inventarisasi disesuaikan dengan kodenya. Setelah diberikan label/tagging, pada setiap alat juga dipasang kode berupa pita sebagai penunjuk kondisi alat-alat tersebut, misalnya:

- Pita hijau untuk alat baru yang belum pernah digunakan.

- Pita biru untuk alat yg sudah digunakan dan beroperasi dengan baik.

- Pita kuning untuk alat yang dalam keadaan beroperasi tetapi tidak optimal dan perlu hati-hati.

- Pita merah untuk alat yang rusak dan harus diperbaiki.

- Pita coklat untuk alat-alat yang baru saja dipergunakan di lapangan dan belum dilakukan pemeriksaan.

- Untuk peminjaman alat, penting untuk dicatat bahwa alat-alat perlengkapan pemadaman kebakaran adalah alat-alat yang sangat penting untuk tetap tersedia di gudang penyimpanan, agar alat-alat tersebut tersedia sewaktu-waktu diperlukan. Namun demikian dalam kondisi tertentu alat-alat tersebut dapat dipinjamkan, dengan ketentuan: mengajukan surat peminjaman yang disetujui oleh Kepala Desa, dan alat harus dikembalikan dalam kondisi baik. Jika terjadi kerusakan maka peminjam harus memperbaikinya.

\subsection{PENUTUP}

Pembelajaran mengenai penguatan MPA ini disusun berdasarkan pengalaman langsung dan kegiatan bersama dengan lima MPA di Kabupaten Bengkalis, Provinsi Riau. Dalam mengefektifkan upaya penanggulangan kebakaran hutan dan lahan, penting untuk dipahami secara mendalam peran dan tugas MPA. Selain itu, hal-hal yang penting untuk dipahami juga adalah: seperangkat alat yang dibutuhkan dan prosedur operasional standar, rencana kerja, sosialisasi dan patroli, prosedur pemadaman dini serta cara untuk menangani peralatan. Pembelajaran ini diharapkan dapat memperkaya perangkat sejenis yang sudah berkontribusi pada upaya peningkatan kinerja MPA dengan berbagai permasalahan yang semakin kompleks. Pembelajaran ini juga diharapkan untuk dapat diterapkan pada MPA dalam berbagai konteks di wilayah lain. Akhir kata, semoga perubahan paradigma dalam penanganan kebakaran hutan dan lahan dapat disertai dengan adanya penguatan kelembagaan dan dukungan yang lebih konkrit dan fokus, terutama dalam menguatkan MPA, sehingga relawan yang tergabung dalam kelompok ini dapat menjalankan peran dan tanggung jawabnya dengan baik. 


\subsection{PUSTAKA}

Badri M, Lubis DP, Susanto D, dan Suharjito D. 2018. Sistem komunikasi peringatan dini pencegahan kebakaran hutan dan lahan di Provinsi Riau. Jurnal PIKOM (Penelitian Komunikasi dan Pembangunan, 19(1):1-16.

Direktur Jenderal Perlindungan Hutan dan Konservasi Alam, Kementerian Lingkungan Hidup dan Kehutanan. 2014. Peraturan Direktur Jenderal Perlindungan Hutan dan Konservasi Alam No. P.2/IV-SET/2014 tentang Pembentukan dan Pembinaan Masyarakat Peduli Api.

Evayanti T dan Zulkarnaini. 2014. Partisipasi organisasi Masyarakat Peduli Api (MPA) terhadap pencegahan dan pengendalian kebakaran hutan dan lahan di Kabupaten Pelalawan. Jurnal IImu Lingkungan, 8(1):1-11.

Kementerian Kehutanan. 2009. Peraturan Menteri Kehutanan No. P.12/Menhut-II/2009 tentang Pengendalian Kebakaran Hutan.

Mardikanto, Totok. 2014. CSR (Corporate Social Responsibility)(Tanggungjawab Sosial Korporasi). Bandung: Alfabeta.

Marnelly TM. 2018. Lembaga masyarakat peduli api: Studi tentang hambatan pelaksanaan peran. Jurnal Antropologi: Isu-Isu Sosial Budaya, 20(2): 223-230.

Meiwanda G. 2016. Kapabilitas Pemerintah Daerah Provinsi Riau: hambatan dan tantangan pengendalian kebakaran hutan dan Iahan. Jurnal IImu Sosial dan IImu Politik, 19(3):251-263. 



\subsection{LATAR BELAKANG}

Berbagai program dan bantuan pemerintah untuk masyarakat pedesaan di Indonesia secara umum disalurkan melalui kelompok-kelompok masyarakat. Pemerintah melalui sejumlah kementerian teknis mensyaratkan dibentuknya lembaga formal bagi kelompok maupun gabungan kelompok, yang disesuaikan dengan program yang akan dilaksanakan dan tujuan yang ingin dicapai. Beberapa contoh kelompok dan gabungan kelompok yang ada di Indonesia antara lain Kelompok Tani (Poktan) dan Gabungan Kelompok Tani (Gapoktan) yang dibentuk oleh Kementerian Pertanian; Kelompok Tani Hutan (KTH) dan Gabungan Kelompok Tani Hutan (Gapoktanhut) yang dibentuk oleh Kementerian Lingkungan Hidup dan Kehutanan; Gerakan Program Kesejahteraan Keluarga (PKK) yang dibentuk oleh Kementerian Dalam Negeri; dan Kelompok Usaha Bersama (KUBE) yang dibentuk oleh Kementerian Sosial. Berdasarkan data yang ada, di sektor pertanian paling tidak terdapat 587.464 Poktan dan 63.392 Gapoktan (Kementerian Pertanian 2018) dan di sektor kehutanan terdapat 25.905 KTH (Kementerian Lingkungan Hidup dan Kehutanan 2019). Hal ini berarti bahwa pada setiap desa bisa ditemukan berbagai lembaga yang cenderung proses pembentukannya didorong oleh pemerintah. Karena masyarakat desa biasanya mempunyai beberapa sumber mata pencaharian dan penghidupan dan terkait dengan beberapa program dari kementerian-kementerian teknis yang berbeda, sering terjadi beberapa orang yang sama bergabung dalam kelompok-kelompok yang berbeda.

Pada proses perjalanan riset aksi partisipatif (RAP), CIFOR bersama masyarakat Desa Dompas, Kecamatan Bukit Batu, Kabupaten Bengkalis, Riau, menyadari perlunya membentuk lembaga Kelompok Tani Hutan (KTH) sebagai persyaratan formal untuk dapat beraktivitas di dalam kawasan hutan. Pembentukan dan penguatan lembaga ini merupakan salah satu bagian penting dalam pelaksanaan RAP untuk pencegahan kebakaran dan restorasi gambut, yang merupakan tahapan dalam studi kelembagaan riset aksi partisipatif untuk pencegahan kebakaran dan restorasi gambut berbasis masyarakat, yang akan dimotori oleh $\mathrm{KTH}^{24}$. $\mathrm{KTH}$ adalah kelompok yang beranggotakan petani yang mengelola usaha di bidang kehutanan, baik di dalam maupun di luar kawasan hutan ${ }^{25}$. Gabungan dari beberapa KTH ini kemudian disebut sebagai Gapoktanhut yang berfungsi untuk lebih mengembangkan usaha. KTH ${ }^{26}$ juga berfungsi sebagai media pembelajaran dan berperan dalam peningkatan kapasitas sumberdaya manusia, pengembangan usaha hasil hutan, dan peningkatan kepedulian terhadap kelestarian.

\footnotetext{
24 Di Provinsi Riau terdapat 23 KTH yang terdiri dari KTH Hutan Desa dan KTH Hutan Tanaman Rakyat. KTH-KTH ini tersebar di Kabupaten Kampar, Bengkalis, Pelalawan, Kepulauan Meranti, Indragiri Hulu, Rokan Hulu, Siak, dan Indragiri Hilir.

25 Kawasan hutan menurut UU No. 41/1999 adalah "wilayah tertentu yang ditunjuk dan atau ditetapkan oleh pemerintah untuk dipertahankan keberadaannya sebagai hutan tetap".

26 Di Provinsi Riau terdapat 23 KTH yang terdiri dari KTH Hutan Desa dan KTH Hutan Tanaman Rakyat. Lokasi sejumlah KTH ini tersebar di Kabupaten Kampar, Bengkalis, Pelalawan, Kepulauan Meranti, Indragiri Hulu, Rokan Hulu, Siak, dan Indragiri Hilir.
} 
Upaya penguatan lembaga KTH seperti yang diharapkan tersebut ternyata dihadapkan pada kendala dan tantangan. Hasil observasi bersama masyarakat pada setengah tahun pertama RAP mendapatkan bahwa lembaga-lembaga masyarakat yang sudah terbentuk tetapi kurang berfungsi. Motivasi untuk melakukan kegiatan bersumber dari proyek-proyek bantuan berjangka pendek yang minim pendampingan. Setelah bantuan proyek selesai, maka kegiatan kembali pasif dan menunggu hingga datang proyek berikutnya. Melalui tahapan siklus refleksi, rencana, aksi dan observasi dalam riset aksi ini, tim peneliti dan masyarakat, termasuk kelompok-kelompok informal dan formal yang sudah ada, bersama-sama memahami kondisi dan memulai kerja kolektif dari beberapa individu dan kelompok-kelompok informal maupun formal yang sudah ada. Selanjutnya secara bersama-sama dibuat kesepakatan untuk merumuskan rencana kegiatan, melaksanakan rencana kegiatan, yang dilanjutkan dengan merefleksikan hasil kegiatan tersebut untuk perbaikan kegiatan berikutnya serta pembelajaran yang bisa dipetik dari proses tersebut.

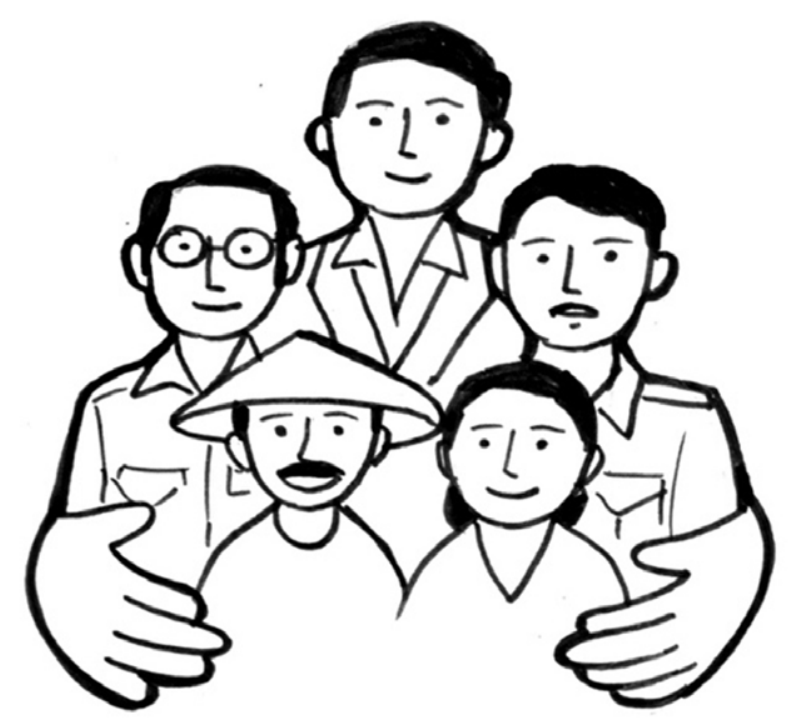

Gambar 8.1 Pembentukan KTH sebagai motor penggerak upaya pencegahan kebakaran dan restorasi gambut berbasis masyarakat 


\subsection{TUJUAN DAN TOPIK PEMBELAJARAN}

Tujuan dari penulisan bab tentang pengembangan lembaga Kelompok Tani Hutan (KTH) Dompas ini adalah untuk mendokumentasikan proses dan hasil RAP dalam pembentukan dan penguatan kelembagaan masyarakat yang berperan penting sebagai penggerak pembangunan di tingkat tapak, khususnya terkait keberdayaan ekonomi masyarakat, pencegahan kebakaran dan restorasi gambut. Tulisan ini diharapkan dapat menjadi bahan pembelajaran dan berbagi pengetahuan dan pengalaman bagi masyarakat dan para pihak terutama aktivis atau agen pembangunan yang terlibat dalam pemberdayaan masyarakat pedesaan.

Fakta dinamis dari lapangan mengingatkan agar tidak mengabaikan berbagai perbedaan dalam kelompok-kelompok masyarakat yang menjadi sasaran: wilayah operasional (misalnya kawasan hutan dan area penggunaan lain); kegiatan, usaha, dan program pendampingan; dan mitra pendamping, kekuatan ikatan sosial. Banyak bukti yang terungkap terkait berhasil atau gagal berkembangnya suatu kelembagaan sangat bergantung dari perhatian atau pengabaian realitas perbedaan yang ada. Pada bagian ini topik-topik diskusi dalam proses penguatan kelembagaan dan pembelajaran diarahkan untuk menjawab pertanyaan-pertanyaan tentang:

- $\quad$ apa yang diperlukan untuk membentuk satu kelompok baru;

- bagaimana menjaga dan meningkatkan keaktifan kelompok-kelompok yang telah ada maupun yang akan dibentuk; dan

- apa strategi dan pendekatan yang perlu dilakukan untuk memberdayakan kelompok agar tercapai kemandirian.

\subsection{KERANGKA KONSEPTUAL RISET AKSI PARTISIPATIF UNTUK PEMBANGUNAN BERBASIS MASYARAKAT}

Pembangunan berbasis masyarakat merupakan sebuah pendekatan yang sejalan dengan pembangunan internasional yang berfokus pada peningkatan kemandirian masyarakat lokal, keadilan sosial, dan pengambilan keputusan secara partisipatif. Pendekatan ini menilai bahwa pertumbuhan ekonomi tidak secara inheren berkontribusi pada pembangunan manusia dan mendorong adanya perubahan nilai dan praktik sosial, politik, dan lingkungan (Korten 1984). Jadi fokus utamanya adalah pembangunan manusia. Konsep pembangunan ini sejalan dengan konsep pembangunan internasional. 


\subsubsection{Kerangka konseptual aksi kolektif}

Aksi kolektif akan terjadi pada saat lebih dari satu individu berkontribusi dalam upaya mencapai suatu hasil (Ostrom 2004). Menurut Ostrom (2004), masyarakat yang berada di daerah terpencil yang memanfaatkan sumber daya alam telah melakukan aksiaksi kolektif yang tergambar pada kegiatan penanaman dan pemanenan bersama, penggunaan fasilitas umum dan pengelolaan sistem irigasi, serta patroli di hutan. Aksi kolektif bermanfaat untuk memperbaiki posisi tawar petani dan memperbaiki akses ke pasar input (masukan) dan output (keluaran) (Paumgarten dkk. 2012). Dalam konteks penanganan bencana, aksi kolektif berperan penting dalam meningkatkan kapasitas adaptif terhadap perubahan lingkungan, termasuk perubahan iklim, mengingat jaringan sosial adalah komponen yang penting dalam pembangunan kapasitas adaptif (Ireland dan Thomalla 2011). Pada sektor kehutanan, masyarakat yang tergabung dalam kelompok dan membentuk aksi kolektif berperan penting dalam mendukung implementasi kebijakan hutan rakyat (Febriani dkk. 2012).

Fokus intervensi RAP adalah menyatukan aksi kolektif parsial yang dilakukan oleh individu maupun kelompok tertentu menjadi kesatuan aksi kolektif yang lebih kuat di dalam suatu kelompok yang lebih besar. Dengan demikian intervensi keberlanjutan proses aksi kolektif pemberdayaan dan pembangunan berbasis masyarakat akan berlangsung secara efisien dan efektif. Keberlanjutan proses inilah yang menjadi tujuan jangka panjang, sehingga partisipasi setiap warga masyarakat merupakan persyaratan penting. Untuk mencapai tujuan tersebut, peneliti RAP perlu memahami berbagai faktor yang mempengaruhi dukungan terhadap berjalan atau tidak berjalannya aksi kolektif. Terutama ketika perubahan dan dukungan tersebut ditujukan sebagai upaya tindakan aksi kolektif dalam mendorong reformasi kebijakan.

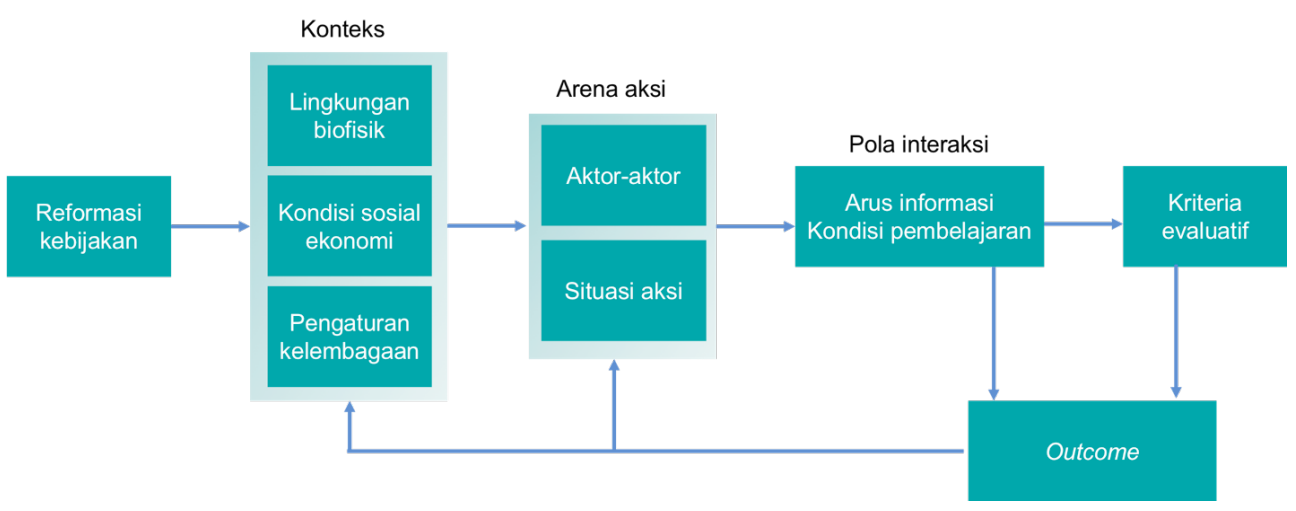

\footnotetext{
Gambar 8.2 Aksi kolektif untuk mendukung reformasi kebijakan berdasarkan kerangka kerja analisis kelembagaan dan pembangunan (IAD)
} 


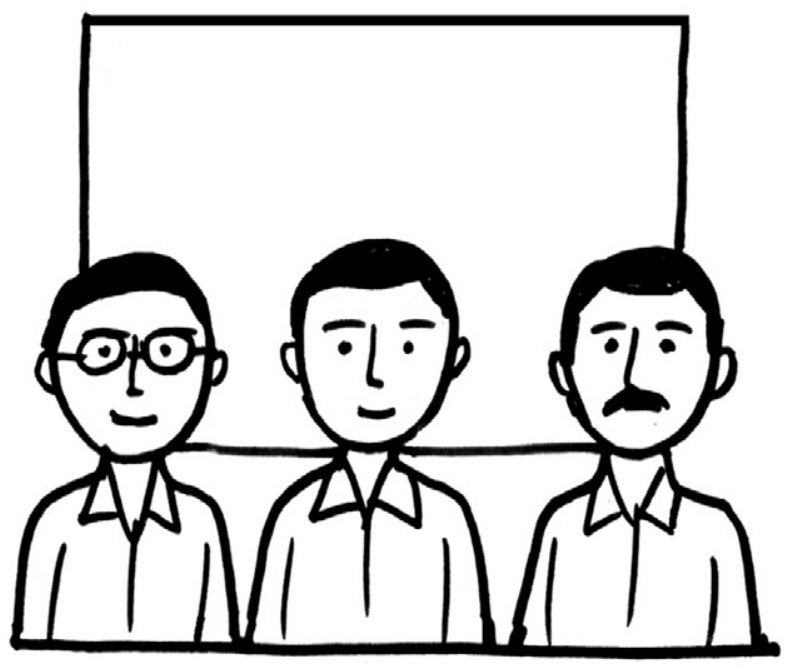

Gambar 8.3 Intervensi dalam riset aksi partisipatif dilakukan guna membentuk aksi kolektif.

RAP di Desa Dompas mengadopsi kerangka kerja analisis kelembagaan yang dikembangkan oleh Ostrom (Gambar 8.2). Dengan demikian proses penyusunan kegiatan RAP perlu mempertimbangkan beragam aspek melalui analisis konteks pada setiap arena dan pola interaksi. Pola interaksi terbentuk dari proses implementasi aksi yang kemudian dievaluasi menggunakan kriteria-kriteria untuk melihat outcome yang dihasilkan.

\subsubsection{Strategi, pendekatan dan metode pemberdayaan dan pembangunan berbasis masyarakat}

Pembangunan yang menggunakan strategi dan pendekatan dengan tujuan menumbuhkan rasa kepemilikan dan tanggung jawab penting untuk meningkatkan aksi kolektif pada masyarakat. Pembangunan akan mencapai hasil sesuai dengan harapan melalui adopsi pembangunan berbasis masyarakat atau community-driven development (Nguyen dan Rieger 2014). Hasil studi Dasgupta dan Beard (2007) dan Kusumatantya (2013) mengenai pembangunan masyarakat mendapatkan beberapa poin kunci yang perlu diperhatikan dalam merumuskan strategi pemberdayaan dan pembangunan berbasis masyarakat (Gambar 8.4). Proyek pemberdayaan dan pembangunan yang berbasis masyarakat dapat berhasil jika desain proyeknya 


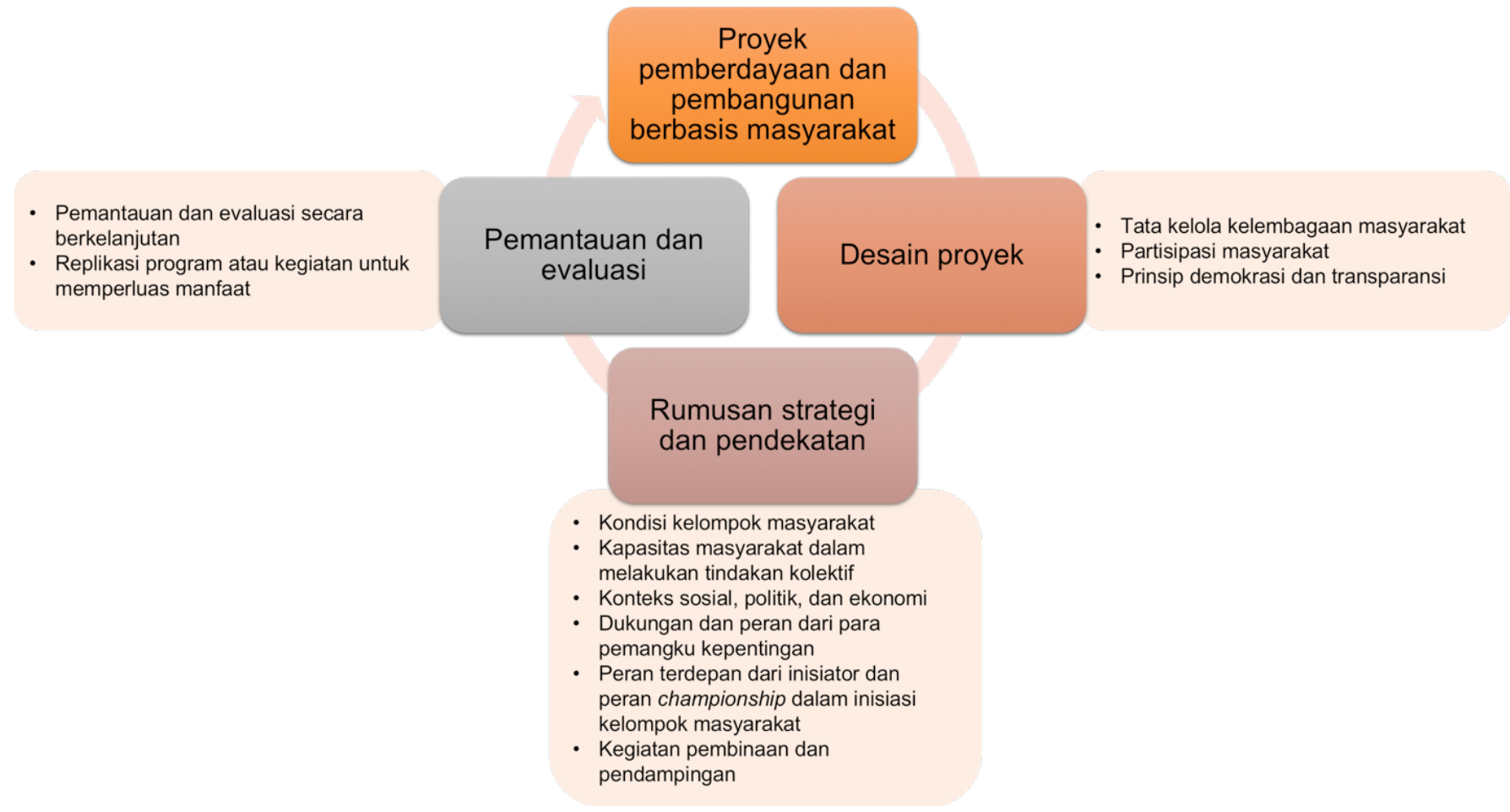

Gambar 8.4 Metode untuk merumuskan proyek pemberdayaan dan pembangunan berbasis masyarakat

Keterangan: Berdasarkan studi Dasgupta dan Beard (2007) dan Kusumatantya (2013). 
mempertimbangkan aspek-aspek yang mendorong terwujudnya tata kelola kelembagaan masyarakat, mengedepankan partisipasi masyarakat dan mengadopsi prinsip-prinsip demokrasi dan transparansi (Dasgupta dan Beard 2007). Selanjutnya desain proyek tersebut dieksekusi dengan merumuskan strategi dan pendekatan yang mempertimbangkan kondisi kelompok masyarakat (misalnya keberagaman ukuran kelompok, kepaduan masyarakat, hirarki sosial dan hubungan kekuasaan); kapasitas masyarakat untuk melakukan tindakan kolektif; konteks sosial, politik, dan ekonomi yang ada (misalnya melalui analisis dukungan kebijakan); membangun dukungan dan peran para pemangku kepentingan; mengedepankan peran inisiator dan peran championship dalam pembentukan atau inisiasi kelompok-kelompok masyarakat; dan adanya kegiatan pembinaan dan pendampingan (Dasgupta dan Beard 2007, Kusumatantya 2013). Setelah implementasi kegiatan dilakukan, perlu adanya pemantauan dan evaluasi secara berkelanjutan. Selain itu, program atau kegiatan yang dinilai berhasil dapat direplikasi untuk memperluas manfaat.

RAP dilakukan berdasarkan metode pengamatan lapangan, wawancara individu, focus group discussion, tindakan (aksi) dan refleksi melalui diskusi bersama individu masyarakat dan pemerintah daerah, kelompok-kelompok masyarakat di Desa Dompas, Kecamatan Bukit Batu, Kabupaten Bengkalis, Riau. Untuk membantu masyarakat mengetahui siapa saja aktor individu dan lembaga yang berperan, memahami tujuan dan berbagai kegiatan, dilakukan diskusi kelompok terfokus dengan menggunakan ZOPP (Zielorientierte Projektplanung) atau metode perencanaan yang berorientasi pada objektif proyek. ZOPP adalah teknik perencanaan untuk menetapkan prioritas dan perencanaan melalui perumusan matrik-matrik secara partisipatif (World Bank 1996). Dua topik yang didiskusikan dengan menggunakan teknik ZOPP adalah: 1) obyektif, aktivitas, dan institusi yang berperan, 2) peran, kepentingan, harapan, dan output dari para pemangku kepentingan.

\subsection{PEMBELAJARAN DARI PPROSES PEMBENTUKAN DAN PENGUATAN LEMBAGA KTH DI DESA DOMPAS}

\subsubsection{Konteks, arena aksi dan pola interaksi}

Pembelajaran dari pembentukan lembaga KTH di Desa Dompas melalui RAP dirangkum dalam sebuah kerangka kerja analisis kelembagaan dan pembangunan (Gambar 8.5). Dalam konteks pencegahan kebakaran dan restorasi gambut berbasis masyarakat, kami melihat adanya regulasi dan komitmen dari berbagai pihak baik di tingkat nasional maupun daerah, dalam memperkuat tata kelola dan implementasi pencegahan kebakaran hutan dan lahan (karhutla), baik di tingkat nasional maupun daerah. Adanya dukungan kebijakan ini, ditambah dengan konteks kelembagaan, biofisik dan kondisi 
Konteks

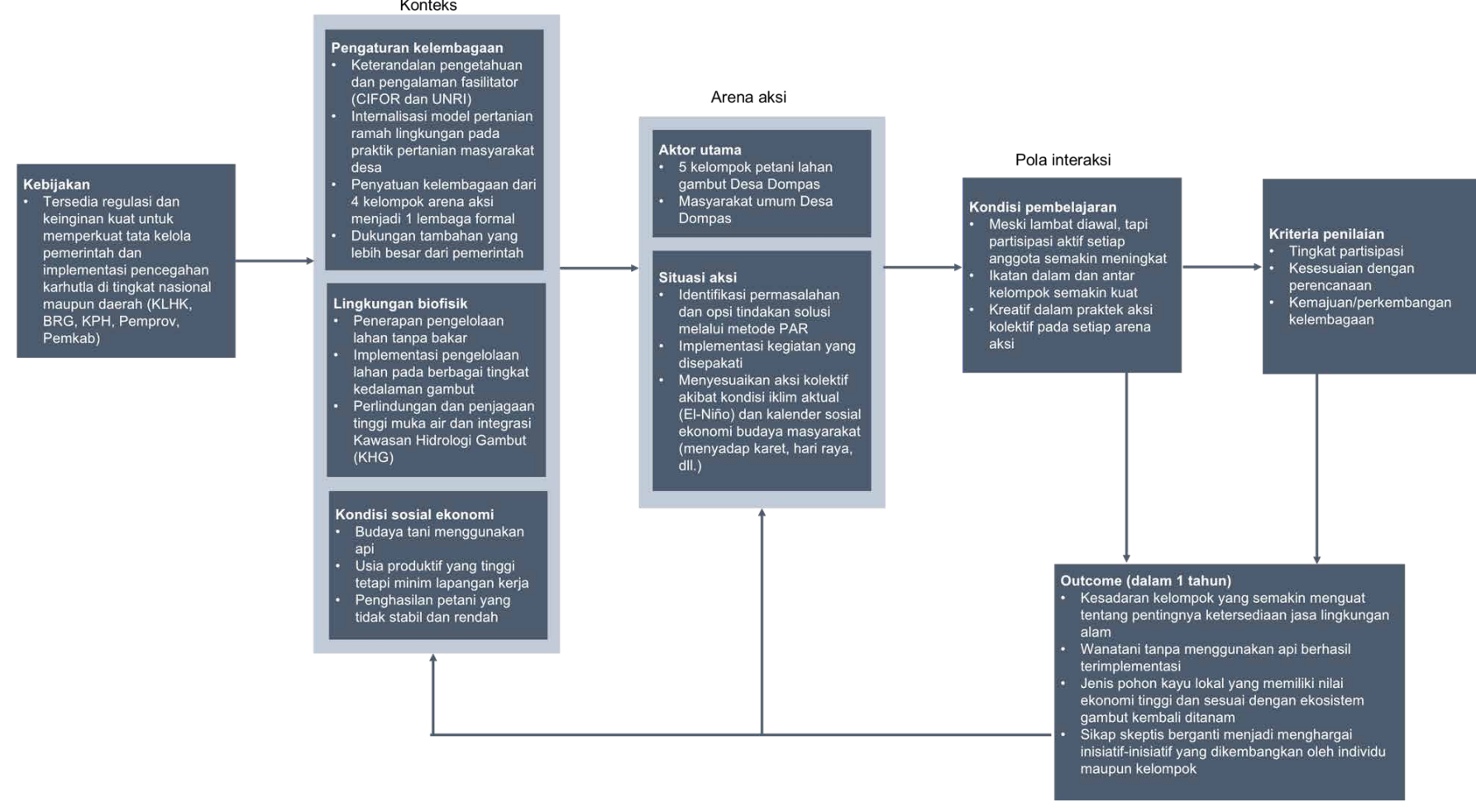

Gambar 8.5 Refleksi pencapaian aksi kolektif di dalam kerangka kerja analisis kelembagaan dan pengembangan di Desa Dompas 
sosial ekonomi menjadi pertimbangan utama dalam merumuskan situasi aksi dengan aktor-aktor utama. Kami mengidentifikasi dan mendapatkan pelajaran mengenai polapola interaksi antar pihak, baik interaksi individu di dalam kelompok, interaksi individu anggota kelompok dengan pihak luar, serta interaksi kelompok dengan pihak luar. Hasil pengamatan mendapatkan meskipun tingkat partisipasi di awal pelaksanaan RAP bergerak agak lambat, namun ketika proses RAP terus dilakukan secara konsisten didapatkan tingkat partisipasi terus meningkat secara bertahap baik jumlah maupun kualitasnya. Kami juga melihat ikatan dalam dan antar kelompok yang semakin kuat dan anggota-anggota kelompok semakin kreatif dalam praktek aksi kolektif di masingmasing arena. Pembelajaran lebih detailnya akan kami sampaikan di bawah ini.

\subsubsection{Aktor pencegahan kebakaran dan restorasi gambut}

\section{- Tujuan, kegiatan, dan institusi yang berperan}

Pada fase awal proyek, bersama-sama dengan masyarakat dilakukan identifikasi permasalahan yang mungkin timbul ketika mengelola lahan publik, lahan pribadi, dan ko-manajemen. Hasil diskusi dan identifikasi mengungkap adanya empat kelompok masalah, yakni: keterampilan teknis budidaya, kondisi biofisik, sosial, dan keuangan. Untuk mengatasi masalah ini dengan tepat, peneliti bersama masyarakat menganalisis masalah yang ada, kemudian mentransformasikan rumusan masalah dengan mengubah pernyataan negatif pada kelompok masalah menjadi pernyataan positif. Hasil dari transformasi ini merupakan tujuan (obyektif) yang dimasukkan ke dalam kolom tujuan di bawah empat kategori tersebut beserta dengan rincian kegiatan yang diperlukan dan institusi yang terlibat (Tabel 8.1).

Tabel 8.1 Identifikasi dan analisis tujuan, kegiatan, dan institusi yang terlibat menggunakan ZOPP.

\section{Tujuan}

\section{Keahlian teknis}

1. Meningkatkan pengetahuan mengenai budidaya dan praktik pengelolaan terbaik.

2. Meningkatkan pengalaman petani.
Kegiatan

Institusi yang berperan

\section{Keahlian teknis}

1. Pelatihan untuk budidaya dan praktik pengelolaan terbaik.

2. Fasilitasi studi banding dan diskusi di arena aksi.
1. CIFOR dan Universitas Riau

2. CIFOR dan Universitas Riau 
Tabel 8.1 sambungan

\begin{tabular}{|c|c|c|}
\hline Tujuan & Kegiatan & Institusi yang berperan \\
\hline Kondisi biofisik & Kondisi biofisik & \\
\hline $\begin{array}{l}\text { 1. Mengurangi risiko banjir } \\
\text { pada musim hujan. } \\
\text { 2. Mengurangi risiko kebakaran } \\
\text { pada musim kemarau. } \\
\text { 3. Mengurangi hama. } \\
\text { 4. Membuang gulma dari } \\
\text { arena-arena aksi. }\end{array}$ & $\begin{array}{l}\text { 1. Mengelola hidrologi, } \\
\text { mengelola sekat kanal, } \\
\text { dan membangun sekat } \\
\text { kanal baru. } \\
\text { 2. Membangun pagar dan } \\
\text { melakukan patroli } \\
\text { rutin hama. } \\
\text { 3. Penyiangan serta aplikasi } \\
\text { herbisida dan kompos. }\end{array}$ & $\begin{array}{l}\text { 1. Pemerintah Desa } \\
\text { Dompas dan } \\
\text { Masyarakat Peduli } \\
\text { Api (MPA) } \\
\text { 2. Pemerintah Desa } \\
\text { Dompas, MPA dan } \\
\text { CIFOR } \\
\text { 3. Pengelola arena aksi } \\
\text { 4. Pengelola arena aksi }\end{array}$ \\
\hline Sosial & Sosial & \\
\hline $\begin{array}{l}\text { 1. Membangun kepercayaan } \\
\text { kelompok. } \\
\text { 2. Menghilangkan } \\
\text { kecemburuan sosial. } \\
\text { 3. Mendapatkan dukungan dari } \\
\text { masyarakat sekitar. } \\
\text { 4. Memberi perhatian pada } \\
\text { kelompok-kelompok } \\
\text { masyarakat. } \\
\text { 5. Meningkatkan kerjasama } \\
\text { antar anggota dan } \\
\text { kelompok. } \\
\text { 6. Mengurangi jumlah kasus } \\
\text { pencurian/tindak pidana } \\
\text { kriminal. }\end{array}$ & $\begin{array}{l}\text { 1. Memfasilitasi } \\
\text { pertemuan masyarakat } \\
\text { dan sosialisasi oleh } \\
\text { pemerintah. } \\
\text { 2. Berdiskusi dengan } \\
\text { masyarakat. } \\
\text { 3. Memfasilitasi sosialisasi. } \\
\text { 4. Memfasilitasi sosialisasi } \\
\text { dan meningkatkan } \\
\text { partisipasi. } \\
\text { 5. Mengembangkan rencana } \\
\text { kerja, implementasi, dan } \\
\text { pemantauan aktivitas. } \\
\text { 6. Patroli rutin dan } \\
\text { terintegrasi. }\end{array}$ & $\begin{array}{l}\text { 1. Pemerintah Desa } \\
\text { Dompas dan MPA } \\
\text { 2. Pemerintah Desa } \\
\text { Dompas } \\
\text { 3. Pemerintah Desa } \\
\text { Dompas } \\
\text { 4. Pengelola Arena } \\
\text { Aksi } \\
\text { 5. Pengelola Arena } \\
\text { Aksi } \\
\text { 6. Pengelola Arena } \\
\text { Aksi }\end{array}$ \\
\hline Keuangan & Keuangan & \\
\hline $\begin{array}{l}\text { 1. Modal untuk: penyiapan } \\
\text { lahan, sarana dan prasarana } \\
\text { pertanian, bibit, pupuk, } \\
\text { herbisida, dan insektisida. } \\
\text { 2. Produk-produk yang } \\
\text { dihasilkan dapat dipasarkan } \\
\text { dengan mudah dan } \\
\text { menghasilkan keuntungan. } \\
\text { 3. Memperoleh pengetahuan } \\
\text { dalam pengelolaan } \\
\text { keuangan. } \\
\text { 4. Adanya transparansi dan } \\
\text { keadilan dalam pembagian } \\
\text { keuntungan. } \\
\text { 5. Mendapatkan penghasilan } \\
\text { tambahan. }\end{array}$ & $\begin{array}{l}\text { 1. Penanaman tahun } \\
\text { pertama dengan bantuan } \\
\text { pendanaan. } \\
\text { 2. Bermitra dengan } \\
\text { pedagang. } \\
\text { 3. Melakukan pelatihan } \\
\text { pengelolaan keuangan. } \\
\text { 4. Diskusi para pihak dan } \\
\text { penentuan mekanisme } \\
\text { bagi hasil. } \\
\text { 5. Implementasi } \\
\text { perencanaan secara } \\
\text { konsisten. }\end{array}$ & $\begin{array}{l}\text { 1. CIFOR dengan } \\
\text { dukungan dana } \\
\text { Temasek Foundation } \\
\text { 2. CIFOR dan } \\
\text { Universitas Riau } \\
\text { 3. CIFOR dan } \\
\text { Universitas Riau } \\
\text { 4. Pengelola arena } \\
\text { aksi, pemilik lahan, } \\
\text { Pemerintah } \\
\text { Desa Dompas, } \\
\text { dan MPA } \\
\text { 5. Pengelola arena aksi }\end{array}$ \\
\hline
\end{tabular}


- Peran, kepentingan, harapan dan keluaran dari para pemangku kepentingan Setelah institusi yang terlibat diidentifikasi, RAP menganalisis dan merumuskan lebih lanjut peran dan minat mereka, dengan harapan dan keluaran terhadap masing-masing institusi (Tabel 8.2).

Tabel 8.2 Identifikasi dan analisis peran, kepentingan, harapan dan keluaran untuk masing-masing pemangku kepentingan.

\begin{tabular}{|c|c|c|c|}
\hline $\begin{array}{l}\text { Pemangku } \\
\text { kepentingan }\end{array}$ & & Peran dan kepentingan & Harapan dan keluaran \\
\hline Pemerintah & $\begin{array}{l}1 . \\
2 . \\
3 . \\
4 .\end{array}$ & $\begin{array}{l}\text { Menjaga agar proyek tetap } \\
\text { berlanjut. } \\
\text { Memandu dan memfasilitasi } \\
\text { pelatihan maupun } \\
\text { pengadaan fasilitas-fasilitas } \\
\text { pendukung. } \\
\text { Memantau kegiatan, } \\
\text { memotivasi, dan bertukar } \\
\text { pikiran (brainstorming) } \\
\text { tentang pengembangan } \\
\text { kegiatan proyek. } \\
\text { Menjadi mediator jika } \\
\text { terjadi konflik. }\end{array}$ & $\begin{array}{l}\text { 1. Untuk mendukung kesuksesan } \\
\text { proyek, pemerintah harus } \\
\text { fokus pada kelompok- } \\
\text { kelompok yang mengelola } \\
\text { arena aksi. } \\
\text { 2. Pemerintah tidak memperoleh } \\
\text { keuntungan apapun karena } \\
\text { mereka memperoleh gaji dari } \\
\text { negara. }\end{array}$ \\
\hline $\begin{array}{l}\text { Pengelola } \\
\text { lahan/arena } \\
\text { aksi }\end{array}$ & $\begin{array}{l}2 . \\
3 . \\
4 .\end{array}$ & $\begin{array}{l}\text { Mengembangkan kemitraan } \\
\text { dengan pihak-pihak } \\
\text { yang terkait. } \\
\text { Perencanaan dan } \\
\text { implementasi dari } \\
\text { rencana aksi. } \\
\text { Membuat rencana kerja. } \\
\text { Mengimplementasikan } \\
\text { dan/ atau terlibat dalam } \\
\text { penyiapan lahan. } \\
\text { Penanaman, pemeliharaan, } \\
\text { pemanenan dan pemasaran } \\
\text { komoditas. } \\
\text { Memperoleh penghasilan } \\
\text { tambahan dari pengelolaan } \\
\text { Arena Aksi } 2 \text { dan } 3 \text {. }\end{array}$ & $\begin{array}{l}\text { 1. Pengelola membutuhkan } \\
\text { dukungan untuk } \\
\text { mengembangkan kemitraan } \\
\text { dengan para pemangku } \\
\text { kepentingan terkait. } \\
\text { 2. Pengelola harus difasilitasi } \\
\text { untuk membuat rencana kerja } \\
\text { dan sistem pemantauan. } \\
\text { 3. Pengelola harus difasilitasi } \\
\text { dalam mengatur jadwal kerja } \\
\text { dan sistem pemantauan. } \\
\text { 4. Komoditas yang diusulkan } \\
\text { untuk ditanam dan dipelihara } \\
\text { akan menghasilkan produk } \\
\text { dengan harga yang tinggi. }\end{array}$ \\
\hline
\end{tabular}


Tabel 8.2 sambungan

\begin{tabular}{|c|c|c|}
\hline $\begin{array}{l}\text { Pemangku } \\
\text { kepentingan }\end{array}$ & Peran dan kepentingan & Harapan dan keluaran \\
\hline Pemilik lahan & $\begin{array}{l}\text { 1. Menyediakan lahan sebagai } \\
\text { arena aksi untuk riset aksi } \\
\text { partisipatif. } \\
\text { 2. Mengetahui beban kerja } \\
\text { dalam pengelolaan lahan. } \\
\text { 3. Mengambil bagian dalam } \\
\text { pembagian keuntungan. } \\
\text { 4. Mengembangkan kemitraan } \\
\text { dengan mitra relevan. } \\
\text { 5. Melanjutkan dukungan } \\
\text { terhadap proyek. }\end{array}$ & $\begin{array}{l}\text { 1. Lahan menjadi lebih produktif. } \\
\text { 2. Secara aktif berpartisipasi } \\
\text { dalam kegiatan proyek. } \\
\text { 3. Mendapatkan laba sebesar } \\
20 \% \text { sesuai dengan } \\
\text { kesepakatan. } \\
\text { 4. Menandatangani perjanjian } \\
\text { kerja sama resmi dan tertulis. } \\
\text { 5. Meminjamkan lahan dalam } \\
\text { waktu lama. }\end{array}$ \\
\hline MPA & $\begin{array}{l}\text { 1. Rekan kerja yang setara } \\
\text { dalam pengelolaan lahan. } \\
\text { 2. Memotivasi para } \\
\text { pengelola lahan. } \\
\text { 3. Membantu mengidentifikasi } \\
\text { sumber-sumber bibit } \\
\text { untuk memenuhi } \\
\text { ketersediaan bibit. } \\
\text { 4. Mencegah kebakaran. } \\
\text { 5. Memitigasi risiko } \\
\text { bencana alam. }\end{array}$ & $\begin{array}{l}\text { 1. Dengan melakukan peran } \\
\text { dan tanggung jawab yang } \\
\text { disebutkan, MPA akan } \\
\text { mendapatkan } 10 \% \text { dari laba } \\
\text { (sesuai dengan kesepakatan) } \\
\text { untuk membantu menutupi } \\
\text { biaya operasional mereka. }\end{array}$ \\
\hline $\begin{array}{l}\text { CIFOR dan } \\
\text { Universitas } \\
\text { Riau }\end{array}$ & $\begin{array}{l}\text { 1. Memfasilitasi setiap proses } \\
\text { kegiatan di Desa Dompas. } \\
\text { 2. Membantu pelaksanaan } \\
\text { proyek, khususnya dalam } \\
\text { hal pendanaan dan } \\
\text { bantuan teknis. } \\
\text { 3. Memantau dan } \\
\text { mengevaluasi. }\end{array}$ & $\begin{array}{l}\text { 1. Mempertahankan ketekunan } \\
\text { dan kesabaran dalam } \\
\text { berurusan, memfasilitasi, dan } \\
\text { bekerja dengan masyarakat. }\end{array}$ \\
\hline
\end{tabular}




\subsubsection{Guliran aksi kolektif dalam konteks formal}

Setelah kelompok-kelompok masyarakat melakukan aksi kolektif secara parsial pada masing-masing arena aksi, kemudian muncul kesadaran bersama akan kebutuhan untuk memperkuat kerja sama antar kelompok dan mengajak pihak-pihak luar untuk bekerja sama. Dengan mempertimbangkan berbagai masukan, maka dipilih bentuk Kelompok Tani Hutan sebagai salah satu platform untuk menjawab kebutuhan ini.

\section{Kotak 8.1. Rumusan aksi kolektif}

Dengan mengacu kerangka IAD, tim peneliti CIFOR bersama masyarakat sepakat untuk merumuskan enam (6) aksi yang diwujudkan dan tersebar dalam bentuk arena aksi, yang diarahkan tidak saja untuk rehabilitasi lahan gambut tetapi sekaligus meningkatkan kelembagaan ekonomi masyarakat. Keenam aksi tersebut adalah:

1. Rehabilitasi lahan bekas kebakaran milik Desa Dompas (seluas 2,2 ha) melalui penanaman pohon dan pembuatan kolam pemancingan ikan. Aksi kolektif pada Arena Aksi 1 ini dilaksanakan oleh kelompok MPA, dan manfaat ekonomi yang dihasilkan menjadi milik MPA.

2. Rehabilitasi lahan bekas kebakaran seluas 3,3 ha milik penduduk desa untuk dijadikan usaha wanatani tanaman kayu yang dikombinasikan dengan tanaman nanas. Aksi kolektif pada Arena Aksi 2 ini dilakukan oleh dua kelompok wanita yang beranggotakan 30 orang. Pencegahan kebakaran dilakukan oleh MPA dengan menjaga tingkat muka air tanah pada kanal dan melakukan patroli rutin. Hasil ekonomi yang diperoleh akan dibagi untuk pemilik lahan, kelompok pengelola, dan MPA.

3. Rehabilitasi lahan bekas kebakaran seluas 3,7 ha milik penduduk desa untuk dijadikan usaha wanatani tanaman kayu dikombinasikan dengan tanaman nanas. Aksi kolektif pada Arena Aksi 3 ini dilakukan oleh satu kelompok lakilaki yang beranggotakan 10 orang. Pencegahan kebakaran dilakukan oleh MPA dengan menjaga tingkat muka air tanah pada kanal dan melakukan patroli rutin. Hasil ekonomi yang diperoleh akan dibagi untuk pemilik lahan, kelompok pengelola, dan MPA.

4. Mengusahakan lahan milik dari tiga rumah tangga (luas total 1,9 ha) oleh masingmasing keluarga sebagai percontohan pada Arena Aksi 4 untuk meningkatkan produktivitas lahan dengan menggabungkan tanaman karet dan kopi. Hasil ekonomi yang diperoleh menjadi milik setiap keluarga, tetapi mereka mempunyai tanggung jawab untuk berbagi pengetahuan dan pengalamannya. 


\section{Kotak 8.1 sambungan}

5. Menanam 311 pohon kelapa hibrida, masing-masing satu pohon di setiap halaman pekarangan rumah warga desa. Aksi ini dimaksudkan untuk mendapatkan perhatian dan dukungan yang lebih luas dari masyarakat desa yang tidak termasuk dalam 5 kelompok di atas. Hasil panen kelapa hibrida tersebut akan menjadi milik setiap keluarga, sedangkan pemasaran kelapa akan dikoordinir oleh lembaga desa.

6. Memperbaiki sekat kanal yang ada dan membangun beberapa sekat kanal baru untuk menjaga kelembaban dan ketersediaan air, terutama pada lokasi arena aksi RAP.

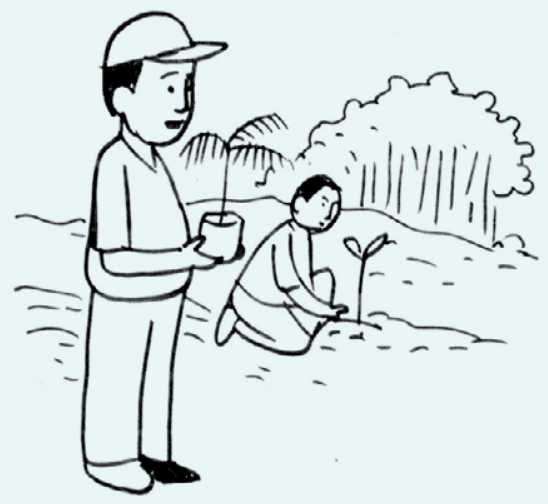

\section{Gambar 8.6 Aksi kolektif dalam rangka pencegahan kebakaran dan restorasi gambut.}

Beberapa hal utama yang perlu diperhatikan dalam pembentukan KTH adalah:

1. Identifikasi kelompok yang memiliki modal sosial dan visi dan misi yang sama, kemudian merumuskan:

a. Nama, visi dan misi KTH

b. Struktur kepengurusan beserta pembagian tugas, peran, tanggung jawab dan wewenang

c. Anggaran Dasar (AD) dan Anggaran Rumah Tangga (ART) dan/atau aturan kelompok 
2. Melengkapi persyaratan administrasi pembentukan $\mathrm{KTH}$, yaitu:

a. Minimal jumlah anggota 15 orang, dengan anggota berdomisili dalam satu wilayah administrasi desa/kelurahan

b. Melakukan kegiatan di bidang kehutanan, misalnya wanatani, pemanfaatan jasa lingkungan, pembibitan, penanaman, pemeliharaan dan pemanenan tanaman kehutanan

c. Berita acara dan dokumen lainnya yang relevan.

3. Mengajukan permohonan registrasi KTH yang sudah terbentuk

\section{Kotak 8.2 Proses pembentukan KTH}

Formalisasi kelembagaan $\mathrm{KTH}$ yang melingkupi aksi kolektif kelompok pada empat arena aksi memerlukan serangkaian diskusi, baik untuk setiap arena aksi maupun antar kelompok arena aksi. Dengan kesadaran untuk memperkuat aksi bersama secara lebih permanen, maka kelompok-kelompok tersebut sepakat untuk melebur menjadi sebuah kelompok besar yang formal. Melalui dua diskusi antar kelompok arena aksi pada pertemuan 2 Juli 2019 di Balai Desa dan tanggal 3 Juli 2019 di Sekretariat RAP, aturan main yang dirumuskan menjadi AD/ART lembaga berhasil disepakati.

Meskipun masih terdapat risiko elite capture dengan Kepala Desa berada pada posisi "Pembina", namun terdapat kemajuan dinamika kelompok yang terlihat dalam pembentukan kepengurusan KTH. Struktur kepengurusan terdiri dari ketua, wakil ketua, sekretaris, bendahara dan beberapa ketua bidang. Ketua bidang mewakili ragam dari kelompok usaha yang terbentuk, misalnya ketua bidang wanatani nanas.

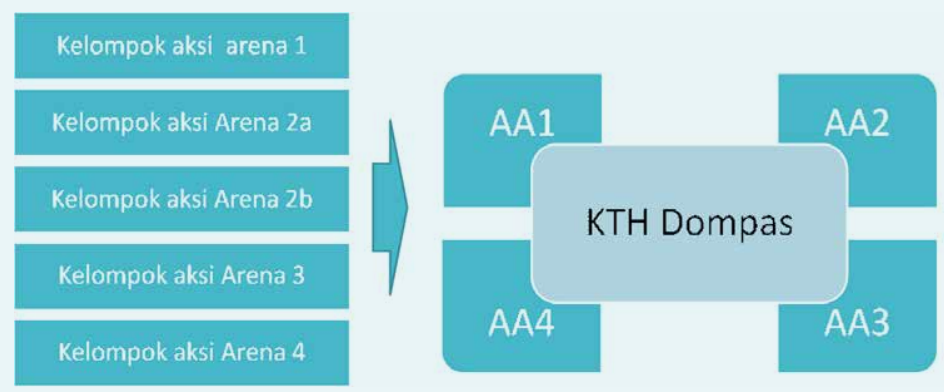

\section{Gambar 8.5 Kelompok arena aksi membentuk satu aksi kolektif yang lebih besar}


Di Desa Dompas, KTH telah dibentuk pada tanggal 3 Juli 2019 dengan anggota awal empat kelompok masyarakat yang terlibat dalam riset aksi partisipatif, yakni para pengelola arena-arena aksi. KTH yang diberi nama "Dompas Ghedang Cemerlang" ini telah terdaftar di Provinsi Riau, melalui keputusan Dinas Kehutanan Propinsi Riau No Kpts.188/PDASRA/3799.

KTH “Dompas Ghedang Cemerlang” memiliki tujuanjangka panjang berupa peningkatan perekonomian masyarakat melalui alternatif mata pencaharian yang ramah gambut dan bebas dari penggunaan api. Untuk mencapai tujuan ini, para anggota sepakat untuk mengembangkan usaha bersama dan alternatif mata pencaharian berkelanjutan melalui pemanfaatan lahan-lahan tidak produktif/kosong (idle land). Pemanfaatan ini dilakukan melalui tata kelola dan praktik budidaya yang baik dan terpadu, dengan mempertimbangkan keberlanjutan ekosistem gambut dan memulihkan gambut dari kerusakan, serta mencegah kebakaran berulang.

\subsubsection{Menjaga semangat dalam kelompok yang lebih besar}

Pembentukan dan pendaftaran KTH merupakan pencapaian awal menuju kemandirian kelompok dalam mewujudkan visi dan misi yang telah disepakati. Beberapa tindak lanjut yang penting untuk dilakukan pada struktur baru ini adalah:

1. Merumuskan rencana kerja tahunan dan identifikasi sumber pendanaan kegiatan.

2. Meminta supervisi dari penyuluh kehutanan dan pembina $\mathrm{KTH}^{27}$, dalam hal pendampingan tiga aspek kelola lestari sebagai berikut:

a. Kelola kelembagaan, termasuk peningkatan kapasitas sumberdaya manusia, pelaporan, dan kaderisasi.

b. Kelola kawasan, termasuk peningkatan pengetahuan tentang batas kawasan hutan dan realisasi sejumlah kegiatan.

c. Kelola usaha, termasuk pengelolaan usaha tani dan pembentukan koperasi.

3. Membangun jaringan kerja sama dengan mitra dan pemangku kepentingan terkait untuk pengembangan usaha kelompok.

27 Sesuai dengan Peraturan Menteri Lingkungan Hidup dan Kehutanan P.89/2019, pendampingan KTH dilaksanakan oleh penyuluh kehutanan/pendamping. KTH akan dievaluasi kinerjanya oleh pendamping, misalnya melalui sistem pemantauan dan evaluasi pendamping http://simping.bp2sdm.menlhk.go.id/ 


\section{Kotak 8.3 Dinamika diskusi kelompok}

Setelah dilakukan penggabungan menjadi kelompok yang lebih besar dan formal, dengan sendirinya aksi kolektif ini menghadapi tantangan yang lebih rumit. Persoalan klasik yang sering terjadi ketika organisasi telah menjadi formal adalah pergerakan organisasi menjadi kurang fleksibel dan cenderung birokratis, ditambah dengan program kerja yang belum tersusun rapi dan terimplementasikan.

Potensi munculnya persoalan tersebut sudah disadari sejak awal oleh anggota dan pengurus lembaga. Untuk itu, dalam rangka menjaga kekompakan dan sinergi, disepakati akan dilakukan pertemuan rutin dua bulanan, sebagai forum berbagi dan menyampaikan kemajuan kegiatan setiap bidang pada setiap arena, dan juga hasil-hasil kerja lain yang dilakukan oleh pengurus.

Pertemuan yang lebih mengedepankan permasalahan akan bermuara pada diskusi yang mengharapkan solusi. Pada kenyataannya, solusi yang bersifat instan tidak akan pernah didapatkan. Oleh karena itu, proses memperoleh solusi maksimal yang bisa dicapai harus dilakukan dengan merumuskan langkah-langkah untuk mencapai solusi tersebut dan mengidentifikasi tindakan aksi kolektif kelompok dengan melibatkan masyarakat yang lebih luas dan lembaga lain di luar KTH.

\subsection{PEMBELAJARAN}

- Refleksi bersama satu tahun perjalanan proyek menunjukkan bahwa masyarakat desa, bersama CIFOR dan UNRI, bergerak pada arah yang benar dan dapat bersinergi. Setiap pihak yang terlibat secara langsung dalam Riset Aksi Partisipatif untuk Pencegahan Kebakaran dan Restorasi Gambut Berbasis Masyarakat merasa puas dengan capaian di tahun pertama dan optimis akan memperoleh hasil yang lebih baik pada tahun berikutnya.

- Meskipun terdapat subyektivitas dalam menilai, dalam satu tahun intervensi untuk menumbuhkan aksi kolektif dan kesadaran masyarakat akan pencegahan kebakaran dan restorasi gambut, terdapat bukti-bukti lapangan yang nyata terkait tumbuhnya kesadaran akan pentingnya keberlanjutan lingkungan. Kesadaran bersama ini menjadikan bertambah kuatnya ikatan sosial, keberhasilan dalam implementasi merubah budaya pertanian menggunakan api menjadi tanpa api, mempertahankan keanekaragaman jenis pohon lokal. 
- Kelompok masyarakat memiliki motivasi yang tinggi untuk belajar dan menjadi lebih baik. Hal ini ditunjukkan dengan tetap bersemangatnya kelompok yang prestasi kerja dari aksi kolektifnya kurang berhasil, misalnya pada kelompok dengan persentase hidup tanaman yang lebih rendah (73\%) dibandingkan kelompok lainnya (di atas 90\%). Kelompok tersebut justru bisa belajar dari ketidakberhasilan yang dialami. Bagi kelompok yang berhasil, kebanggaan yang dirasakan kelompok ini semakin memperkuat ikatan di dalam kelompok dan keinginan untuk berbagi kunci keberhasilannya kepada kelompok lain.

\subsection{PUSTAKA}

Dasgupta A dan Beard VA. 2007. Community driven development, collective action and elite capture in Indonesia. Development and Change, 38(2): 229-249.

Febriani D, Darusman D, Nurrochmat DR, dan Wijayanto N. 2012. Strategi implementasi kebijakan hutan tanaman rakyat di Kabupaten Sarolangun, Jambi. Jurnal Analisis Kebijakan Kehutanan, 9(2): 81-95.

Ireland P dan Thomalla F. 2011. The role of collective action in enhancing communities' adaptive capacity to environmental risk: an exploration of two case studies from Asia. PLOS Currents Disasters, 1.

Kementerian Lingkungan Hidup dan Kehutanan. 2018. Peraturan Menteri Lingkungan Hidup dan Kehutanan P.89/MENLHK/SETJEN/KUM.1/8/2018 tentang Pedoman Kelompok Tani Hutan. Jakarta: Kementerian Lingkungan Hidup dan Kehutanan.

Kementerian Lingkungan Hidup dan Kehutanan. 2019. Info petani hutan. [diakses pada: 26 Agustus 2019]. http://simping.bp2sdm.menlhk.go.id

Kementerian Pertanian. 2018. Statistik Pertanian 2018. Jakarta: Kementerian Pertanian.

Korten DC. 1984. Strategic Organization for People-Centered Development. Public Administration Review, 44(4): 341-352.

Kusumatantya I. 2013. Peran pemangku kepentingan dalam pembentukan komunitas guna mencapai ketahanan sosial ekonomi masyarakat. Jurnal Wilayah dan Lingkungan, 1(1): 22-48.

Nguyen TC dan Rieger M. 2014. Community-driven development and social capital, evidence from Morocco. EUI Working Paper MWP 2014/02. Italia: European University Institute.

Ostrom E. 2010. Analyzing collective action. Agricultural Economics, 41(S1): 155-166.

Ostrom E. 2004. Collective action and property rights for sustainable development understanding collective action. Focus 11, Brief 2 of 16. Washington DC: International Food Policy and Research Institute. 
Paumgarten F, Kassa H, Zida M, dan Moeliono M. 2012. Benefits, challenges, and enabling conditions of collective action to promote sustainable production and marketing of products from Africa's dry forests. Review of Policy Research, 29(2): 229-250.

World Bank. 1996. The World Bank Participation Sourcebook. Washington DC: Environmentally Sustainable Development. 


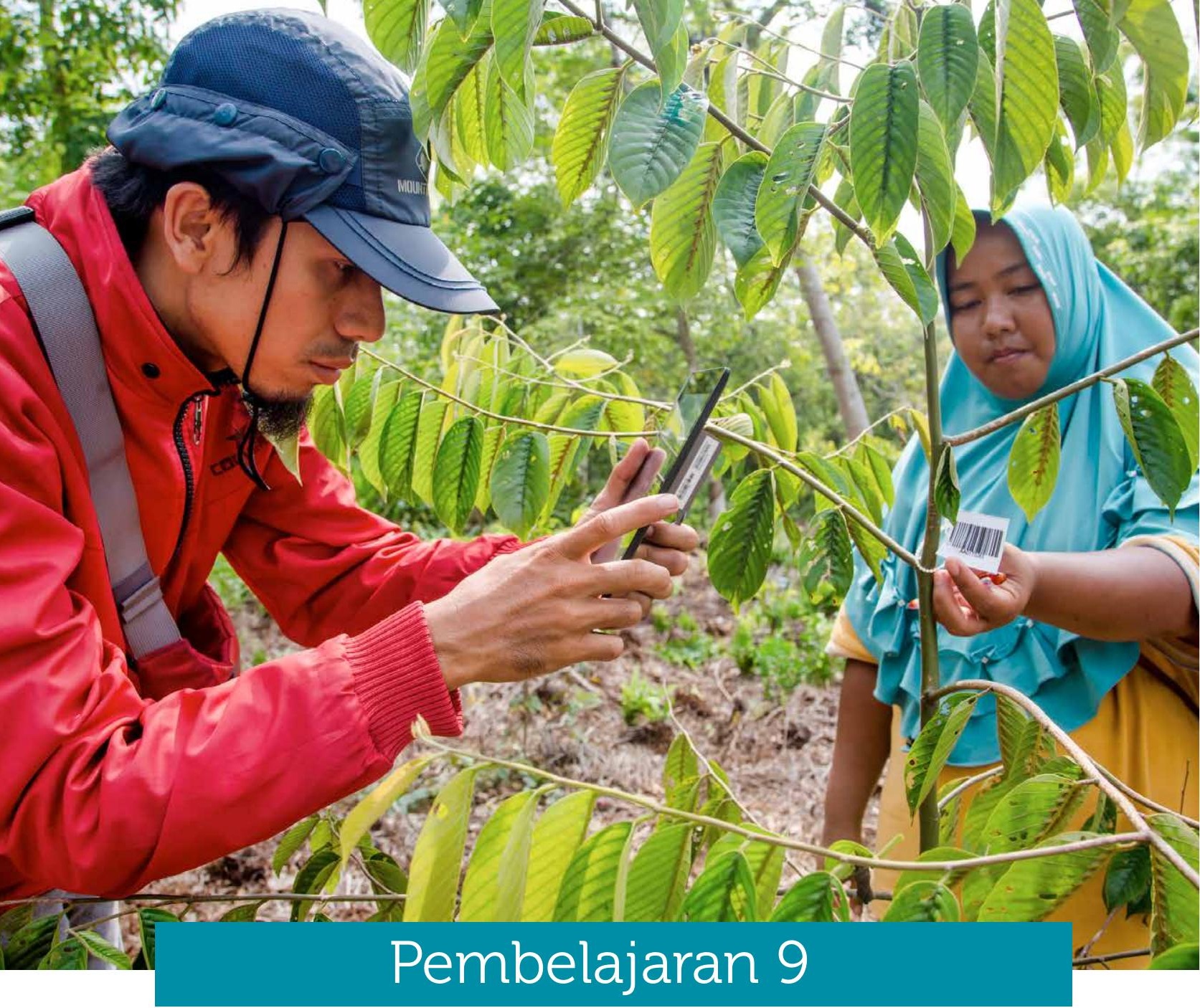

\section{Sistem Pemantauan Restorasi Gambut Berbasis Masyarakat} COmmunity-based Peatland RestOration MonItoring SystEm (CO-PROMISE)

Beni Okarda, Herry Purnomo, Imam Basuki, Usman Muchlish, Shintia Arwida dan Himlal Baral 


\subsection{PENDAHULUAN}

COmmunity-based Peatland RestOration Monltoring SystEm (CO-PROMISE) adalah sistem pemantauan berbasis masyarakat yang bertujuan menyediakan basis data dengan informasi spasial untuk menyimpan data hasil pemantauan kegiatan restorasi di lahan gambut. Sistem ini dirancang agar mudah digunakan oleh semua pihak tanpa mengurangi kualitas data. CO-PROMISE menggunakan platform Open Data Kit (ODK) yang terdiri dari aplikasi ODK Collect pada perangkat berbasis Android dan KoBo ToolBox yang berbasis penyimpanan awan (cloud storage), dipadukan dengan aplikasi Microsoft Power Bl untuk mendesain tampilan dan menyajikan hasil pengukuran pada pusat kontrol panel online. Sistem ini memungkinkan penyimpanan data hasil pengukuran secara berkala yang bisa ditampilkan pada dashboard dan disesuaikan dengan kebutuhan pengguna.

Panduan ini merupakan bagian dari proyek Riset Aksi Partisipatif - Pencegahan Kebakaran dan Restorasi Lahan Gambut Berbasis Masyarakat (Participatory Action Research on Community-based Fire Prevention and Peatland Restoration - PARCBFPR). Dalam riset ini, dengan difasilitasi oleh Pusat Penelitian Kehutanan Internasional (CIFOR), masyarakat setempat melakukan serangkaian kegiatan pencegahan kebakaran dan restorasi lahan gambut, dengan pendekatan yang diperkenalkan oleh Pemerintah Republik Indonesia melalui Badan Restorasi Gambut (BRG). Pendekatan tersebut dikenal dengan 3R (Rewetting, Revegetation, Revitalization), yang terdiri dari pembasahan lahan gambut, penanaman pohon, dan revitalisasi penghidupan masyarakat setempat. Pembasahan lahan gambut dilakukan dengan membuat sekat kanal untuk menjaga tinggi muka air pada lahan gambut yang terdegradasi, sesuai dengan peraturan yang berlaku, yaitu setinggi $40 \mathrm{~cm}$. Dengan menjaga tinggi permukaan air, diharapkan tingkat kelembaban gambut akan terkontrol sehingga dapat mencegah terjadinya kebakaran. Penanaman pohon bertujuan untuk mengembalikan vegetasi alami ekosistem gambut agar dapat menyerap emisi karbondioksida dari atmosfir. Upaya ini dilakukan dengan melakukan penanaman jenis-jenis pohon yang direkomendasikan oleh Kementerian Lingkungan Hidup dan Kehutanan. Revitalisasi penghidupan bagi masyarakat setempat dilakukan dengan menerapkan sistem wanatani melalui budidaya nanas dan kopi, serta budidaya kelapa hibrida di pekarangan rumah.

Untuk memantau perkembangan dan dampak kegiatan, sebuah sistem pemantauan yang terintegrasi dibangun dengan melibatkan masyarakat setempat untuk melakukan pengukuran dan pengumpulan data. Sistem ini terdiri dari pemantauan lahan gambut, pemantauan pohon, pemantauan nanas, dan pemantauan kelapa. Kegiatan pemantauan lahan gambut mencakup pemantauan efek dari sekat kanal sebagai bagian dari proses pembasahan gambut. Kami bekerjasama dengan masyarakat setempat untuk melakukan pengukuran Tinggi Muka Air (TMA) dan kelembaban tanah 
pada area terdampak sekat kanal dan area yang tidak terdampak sekat kanal setiap minggu dan melaporkannya melalui sistem ini. Selain itu, dilakukan juga pengukuran tingkat subsiden gambut dengan periode pemantauan yang lebih panjang. Kegiatan pemantauan pohon dilakukan untuk memantau jumlah pohon yang sudah tertanam sebagai bagian dari proses revegetasi. Setiap pohon dipantau pertumbuhan dan tingkat kelangsungan hidupnya (survival rate) dengan sistem ini. Masyarakat setempat diberikan pelatihan untuk melakukan inventarisasi pohon dan memantau pertumbuhannya secara berkala. Kegiatan pemantauan terhadap nanas dan kelapa dilakukan untuk memantau jumlah komoditas yang sudah tertanam sebagai bagian upaya peningkatan ekonomi masyarakat setempat. Komoditas ini dipilih berdasarkan hasil diskusi dengan masyarakat setempat menggunakan kanvas model bisnis pada fase awal proyek ini.

Seluruh data pemantauan tersimpan dalam sistem penyimpanan data berbasis awan (cloud-based storage) dan ditampilkan pada dashboard dalam jaringan (online) agar dapat diakses oleh seluruh pemangku kepentingan yang terlibat dalam proyek maupun bagi pihak lain yang terlibat dalam kegiatan restorasi.

\subsection{SISTEM PEMANTAUAN}

\subsubsection{Komponen pemantauan}

CO-PROMISE terdiri dari beberapa jenis pemantauan berdasarkan pendekatan kegiatan restorasi 3R. Komponen pemantauan didasarkan dari tipe kegiatan restorasi yang dilakukan dalam proyek PAR-CBFPR. Setiap parameter memberikan informasi mengenai perkembangan kegiatan restorasi dan dampak dari kegiatan tersebut.

Dalam pemantauan lahan gambut, dampak dari pembangunan sekat kanal ditampilkan dalam parameter tinggi muka air, kelembaban tanah, radiasi matahari dan tingkat subsiden gambut. Untuk mengetahui efek dari sekat kanal terhadap upaya pembasahan gambut, nilai dari masing-masing parameter tersebut dibandingkan antara area yang tekena dampak sekat kanal dengan area yang tidak terdampak sekat kanal. Kegiatan pemantauan pohon memantau kegiatan revegetasi melalui penanaman jenis-jenis pohon yang direkomendasikan untuk pemulihan ekosistem. Parameter yang digunakan adalah jumlah pohon, jenis pohon, tingkat keberlangsungan hidup, dan kondisi pertumbuhannya melalui pengamatan pertambahan tinggi pohon atau diameter batang. Hasil pemantauan ini juga dapat menginformasikan spesies pohon dengan tingkat pertumbuhan yang baik untuk proses revegetasi di lahan gambut. 
Kegiatan pemantauan revitalisasi penghidupan masyarakat setempat dilakukan berdasarkan jenis komoditas yang dibudidayakan. Untuk komoditas di lahan gambut, pemantauan nanas akan memberikan informasi mengenai jumlah tanaman, buah, dan tingkat keberlangsungan hidup tanaman. Untuk komoditas di lahan non-gambut, pemantauan kelapa hibrida, dilakukan dengan menghitung jumlah tanaman, tingkat keberlangsungan hidup, dan jumlah masyarakat yang mendapatkan manfaat dari program tersebut. Seluruh informasi pengukuran dan hasil pemantauan dilengkapi dengan titik koordinat lokasi dan didokumentasikan dalam bentuk gambar.

Tabel 9.1 Komponen pemantauan

\begin{tabular}{|c|c|c|c|c|}
\hline Jenis kegiatan & \multicolumn{2}{|c|}{ Aktivitas } & $\begin{array}{c}\text { Tipe } \\
\text { pemantauan }\end{array}$ & Parameter pemantauan \\
\hline $\begin{array}{l}\text { Pembasahan } \\
\text { gambut / } \\
\text { Rewetting }\end{array}$ & \multicolumn{2}{|c|}{ Pembuatan sekat kanal } & $\begin{array}{l}\text { Pemantauan } \\
\text { gambut }\end{array}$ & $\begin{array}{l}\text { - Tinggi muka air } \\
\text { - Kelembaban tanah } \\
\text { - Radiasi matahari } \\
\text { - Subsiden }\end{array}$ \\
\hline $\begin{array}{l}\text { Revegetasi/ } \\
\text { Revegetation }\end{array}$ & \multicolumn{2}{|c|}{ Penanaman pohon } & $\begin{array}{l}\text { Pemantauan } \\
\text { pohon }\end{array}$ & $\begin{array}{l}\text { - Jumlah pohon } \\
\text { - Tingkat } \\
\text { keberlangsungan } \\
\text { hidup } \\
\text { - Jenis pohon } \\
\text { - Tinggi pohon }\end{array}$ \\
\hline \multirow{2}{*}{$\begin{array}{l}\text { Revitalisasi } \\
\text { penghidupan } \\
\text { masyarakat } \\
\text { setempat/ } \\
\text { Revitalization } \\
\text { of local } \\
\text { livelihood }\end{array}$} & \multirow[t]{2}{*}{$\begin{array}{l}\text { Penanaman } \\
\text { komoditas } \\
\text { bernilai } \\
\text { tinggi }\end{array}$} & $\begin{array}{l}\text { lahan } \\
\text { gambut: } \\
\text { nanas }\end{array}$ & $\begin{array}{l}\text { Pemantauan } \\
\text { Nanas }\end{array}$ & $\begin{array}{l}\text { - Jumlah tanaman } \\
\text { - Jumlah buah } \\
\text { - Tingkat } \\
\text { keberlangsungan } \\
\text { hidup }\end{array}$ \\
\hline & & $\begin{array}{l}\text { lahan non- } \\
\text { gambut: } \\
\text { kelapa } \\
\text { hibrida }\end{array}$ & $\begin{array}{l}\text { Pemantauan } \\
\text { Kelapa Hibrida }\end{array}$ & $\begin{array}{l}\text { - Jumlah tanaman } \\
\text { - Tingkat } \\
\text { keberlangsungan } \\
\text { hidup } \\
\text { - Tinggi tanaman } \\
\text { - Informasi pemilik }\end{array}$ \\
\hline
\end{tabular}

\subsubsection{Alur kerja sistem}

CO-PROMISE menggunakan perangkat gawai berbasis Android dengan aplikasi ODK Collect yang dapat dioperasikan tanpa menggunakan koneksi internet untuk memasukkan data. Masyarakat yang telah terlatih dapat secara sukarela mengukur obyek pengamatan, memasukkan hasil pengukuran tersebut, dan mengirimkannya ke pusat data ketika sudah terkoneksi dengan internet. Untuk meminimalisasi kesalahan 


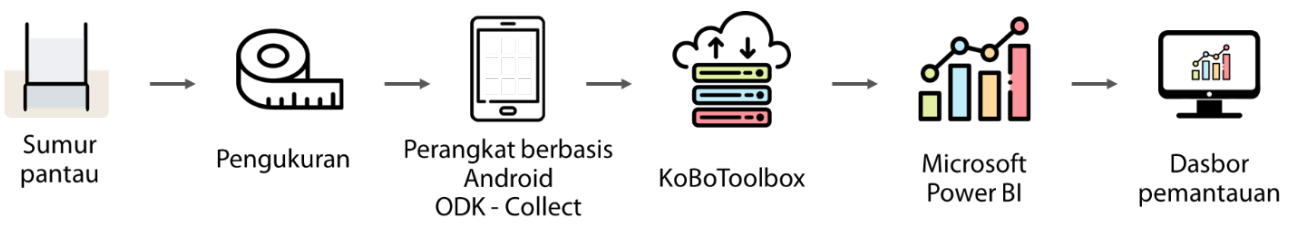

\section{Gambar 9.1 Alur kerja sistem pemantauan gambut}

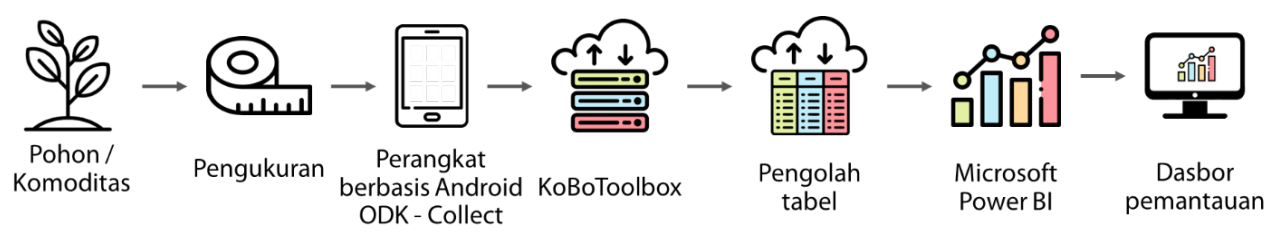

Gambar 9.2 Alur kerja sistem pemantauan pohon, kelapa, dan nanas

dalam memasukkan data, nilai masukan telah diatur agar berada dalam rentang nilai batas wajar. Pencatatan tertulis tetap dilakukan sebagai bahan perbandingan apabila ditemukan adanya kejanggalan data.

Alur kerja pemantauan gambut sedikit berbeda dibandingkan dengan ketiga jenis pemantauan lainnya. Pemantauan gambut dirancang untuk dilakukan setiap minggu untuk mengetahui dinamika hidrologi gambut. Sistem ini dirancang agar data dapat ditampilkan sesaat setelah pengukuran. Setelah data hasil pengukuran dikirimkan, basis data online akan langsung diperbarui secara otomatis. Dalam satu hari, Microsoft Power Bl akan melakukan pembaruan data dua kali dan secara otomatis memperbarui tampilan dashboard online. Untuk pemantauan pohon, tanaman nanas, dan kelapa, data diubah menjadi berkas tabel terlebih dahulu untuk pengecekan sebelum ditampilkan pada dashboard.

\subsubsection{Penggunaan barcode}

Untuk mendapatkan data pemantauan berkala yang terstruktur, digunakan nomor identifikasi unik (ID) untuk setiap subyek pemantauan, misalnya ID Sumur Pantau untuk pemantauan gambut, ID Pohon untuk pohon, kopi dan kelapa, dan ID Blok Tanam untuk pemantauan nanas. Tipe alfanumerik digunakan untuk membuat nomor identifikasi yang unik. Susunan huruf dan angka dalam ID tersebut akan memberikan informasi mengenai lokasi arena aksi, subyek pemantauan, dan ID unik dari masingmasing subyek pengukuran. 

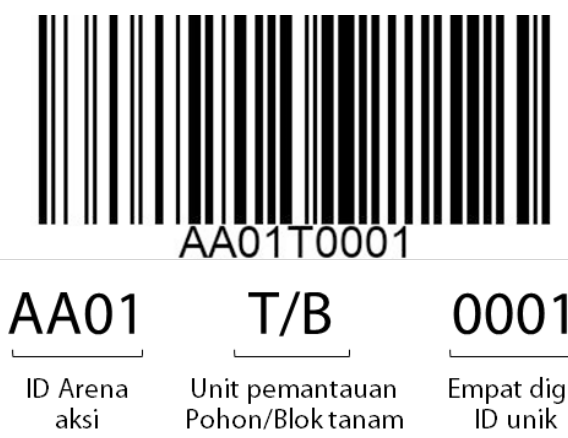

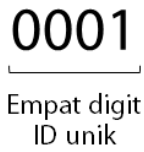

ID unik
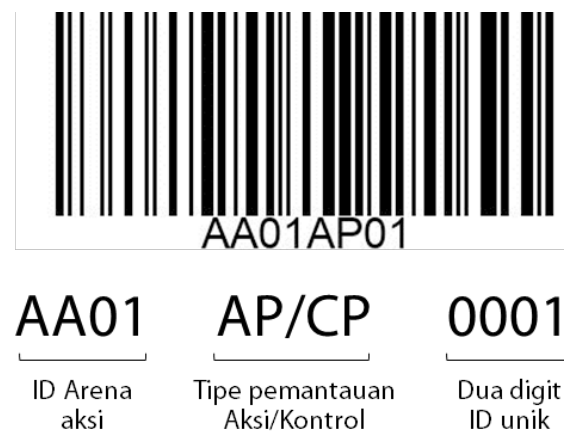

AP/CP

Tipe pemantauan Aksi/Kontrol
0001

Dua digit

ID unik

Gambar 9.3 Struktur ID Pohon dan Blok Tanam Nanas

Gambar 9.4 Struktur ID Sumur Pantau

Mengingat panjangnya jumlah karakter ID dan banyaknya jumlah subyek pengukuran, kemungkinan terjadinya kesalahan penulisan sangat besar. Selain itu, waktu yang diperlukan untuk menuliskan setiap karakter akan semakin lama. Kesalahan penulisan ID selalu ditemukan pada saat sistem ini diujicobakan. Untuk menghindari kesalahan penulisan dan mempersingkat waktu, susunan karakter ID diubah menjadi barcode berjenis Code 128. Barcode tersebut dicetak pada bahan yang tahan cuaca dan dipasang pada subyek pengukuran. Aplikasi ODK Collect memiliki kemampuan untuk memindai barcode melalui perangkat kamera. Pemindai barcode dapat membaca susunan karakter barcode dengan cepat dan tepat sehingga menghindari kesalahan penulisan dan mempersingkat waktu dibandingkan pengetikan manual.

\subsubsection{Pembuatan sumur pantau dan tiang pengukur subsiden}

Penempatan lokasi pengamatan hidrologis gambut atau sumur pantau dan tiang pemantau subsiden sangat penting untuk memahami dan mengukur dampak pembuatan sekat kanal terhadap pembasahan. Terdapat dua jenis sumur pantau, yaitu yang dibangun di dalam Arena Aksi, yang merupakan area terdampak pembuatan sekat kanal, dan yang dibuat di luar namun di sekitar Arena Aksi sebagai titik kontrol dan pembanding dengan kondisi tanpa sekat kanal. Pada setiap Arena Aksi, dibuat masing-masing empat buah sumur pantau di dalam dan luar Arena Aksi. Dua sumur pantau dipasang sepanjang sisi kanal dengan jarak antar titik sejauh $100 \mathrm{~m}$ dan dua sumur pantau lainnya dipasang sejauh 100 m menjauhi kanal. Pemilihan jarak 100 m didasarkan pada kondisi hidrologis lokasi Arena Aksi. Ritzema dkk. (2014) melaporkan bahwa kanal dapat mempengaruhi tinggi muka air lahan gambut hingga jarak 1000 m dari kanal. Berdasarkan pemetaan awal, diketahui bahwa jarak antar kanal di sekitar 


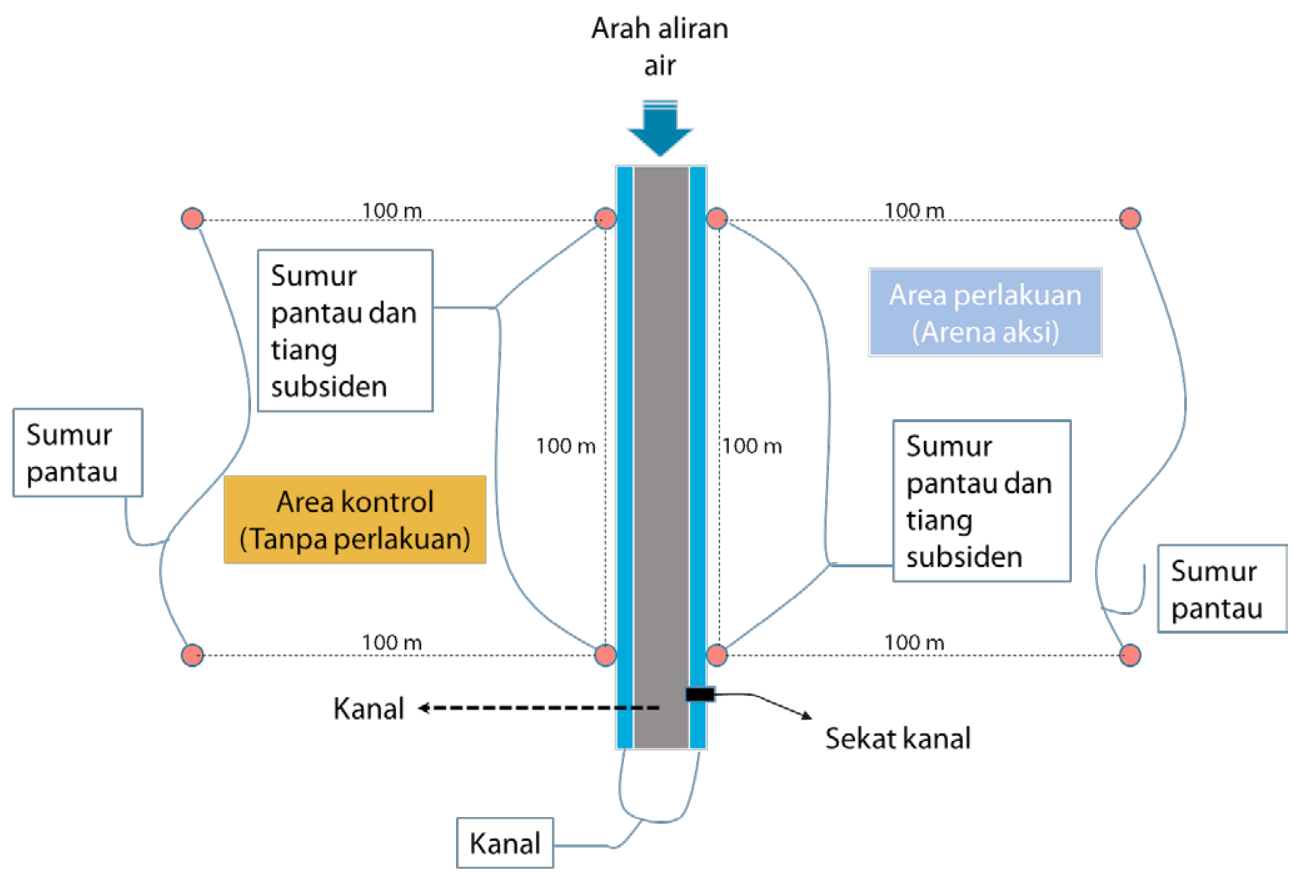

\section{Gambar 9.5 Penempatan sumur pantau pemantauan gambut}

lokasi Arena Aksi adalah 400 m, sehingga jarak 100 m dianggap sebagai wilayah yang dipengaruhi oleh kanal yang disekat dan tidak dipengaruhi oleh kanal yang berada di wilayah sekitarnya. Hal ini dengan mempertimbangkan bahwa wilayah di antara dua kanal dipengaruhi oleh kedua kanal. 


\subsection{PENGGUNAAN APLIKASI ODK COLLECT DALAM PEMANTAUAN}

\subsubsection{Petunjuk umum}

\section{Instalasi awal dan pengaturan antarmuka perangkat}

1. Buka Play Store, kemudian cari dan pasang (install) aplikasi ODK Collect pada perangkat Android anda.

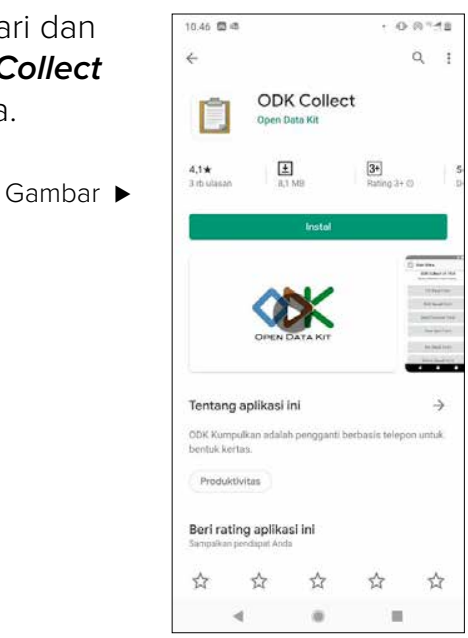

2. Buka aplikasi ODK Collect pada perangkat anda dan pilih ikon berbentuk tiga titik pada sudut kanan atas, lalu pilih Pengaturan umum, kemudian pilih Antarmuka pengguna. Untuk memudahkan penggunaan, pilih bahasa yang diinginkan pada fitur Bahasa dan pilih Navigasi menjadi Gunakan sapuan dan tombol.

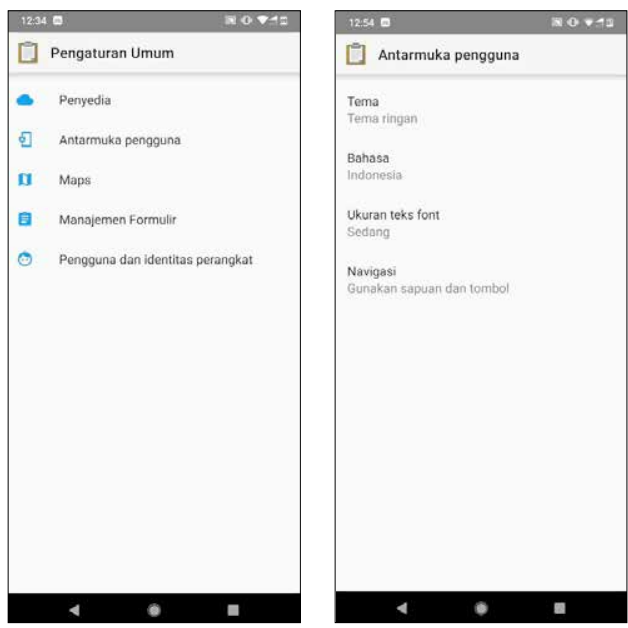




\section{Pengaturan server dan pengambilan formulir}

1. Pada perangkat Android, buka aplikasi ODK Collect. Pilih ikon

berbentuk tiga titik pada sudut kanan atas, lalu pilih Pengaturan Umum.

Gambar

2. Di dalam Pengaturan Umum, cari dan pilih Penyedia. Di bawah Tautan (URL), masukkan server URL: http:// koboform.cifor.org. Pada langkah ini, anda juga diminta memasukkan Nama pengguna dan Kata sandi yang telah di berikan.

Gambar

3. Unduh formulir terbaru atau perbarui formulir dengan memilih Ambil formulir kosong. Pastikan perangkat anda terhubung dengan internet.

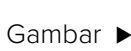

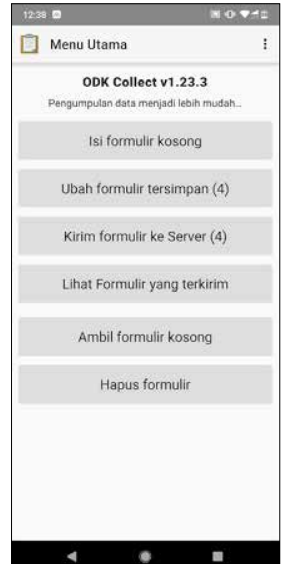
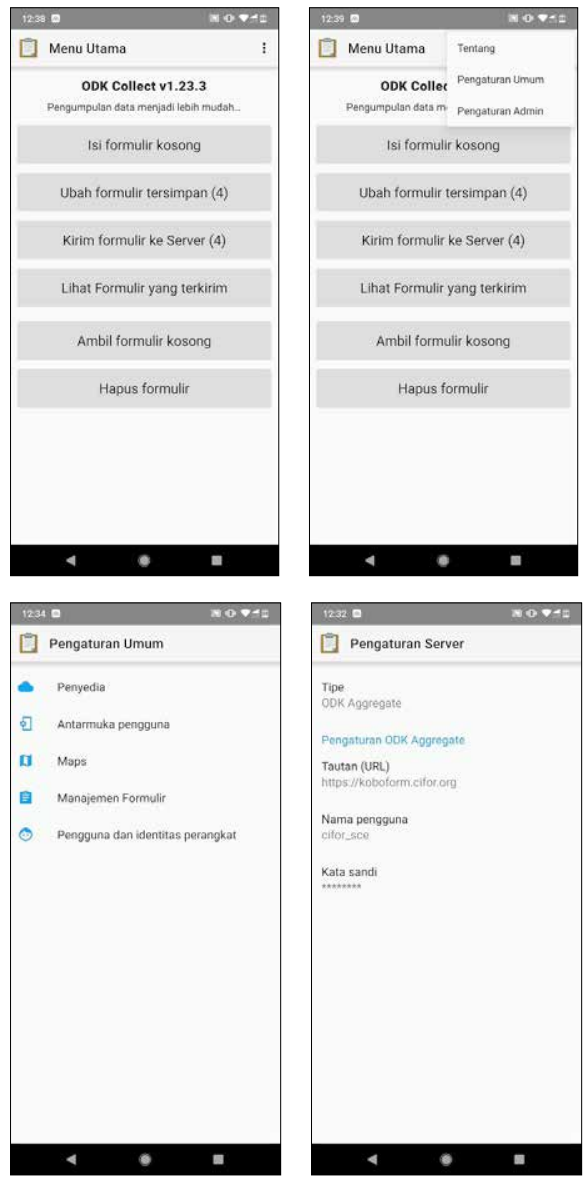

Pengaturan Server

0 Pengaturan Umum

- Penyedia

요 Antarmuka pengoun

al Mops

目 Monajemen Formult

- Pengguna dan identitas perangk:

4

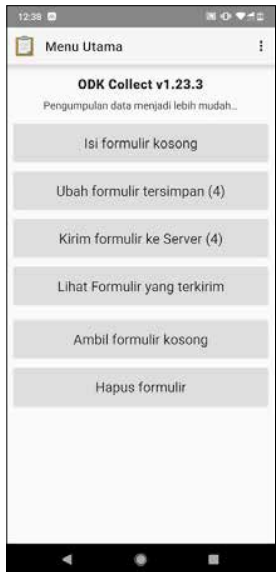


4. Serangkaian pilihan formulir yang terhubung dengan akun anda akan tampil. Pilih semua (atau salah satu dari form yang anda inginkan) dengan memilih tanda centang (checklist) di sisi kanan lalu pilih Ambil. Untuk memastikan formulir siap digunakan, silahkan kembali ke menu utama dan pilih Isi formulir kosong, dan pastikan formulir yang anda unduh sudah tercantum disana.

Gambar

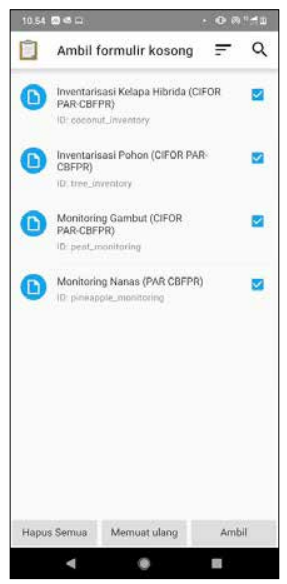

\section{Pengisian data dan penyimpanan}

1. Untuk memulai pengisian data, pilih Isi formulir kosong pada halaman Menu Utama dan pilih formulir survei untuk memulai.

Gambar

2. Platform ini dirancang menggunakan dua bahasa (Bahasa Indonesia dan Bahasa Inggris/English). Untuk mengubah bahasa, pilih ikon tiga titik di sudut kanan atas, lalu pilih Ubah Bahasa, yang akan menampilkan pilihan penggunaan bahasa. Dalam pengaturan awal, bahasa yang digunakan adalah Bahasa Inggris.
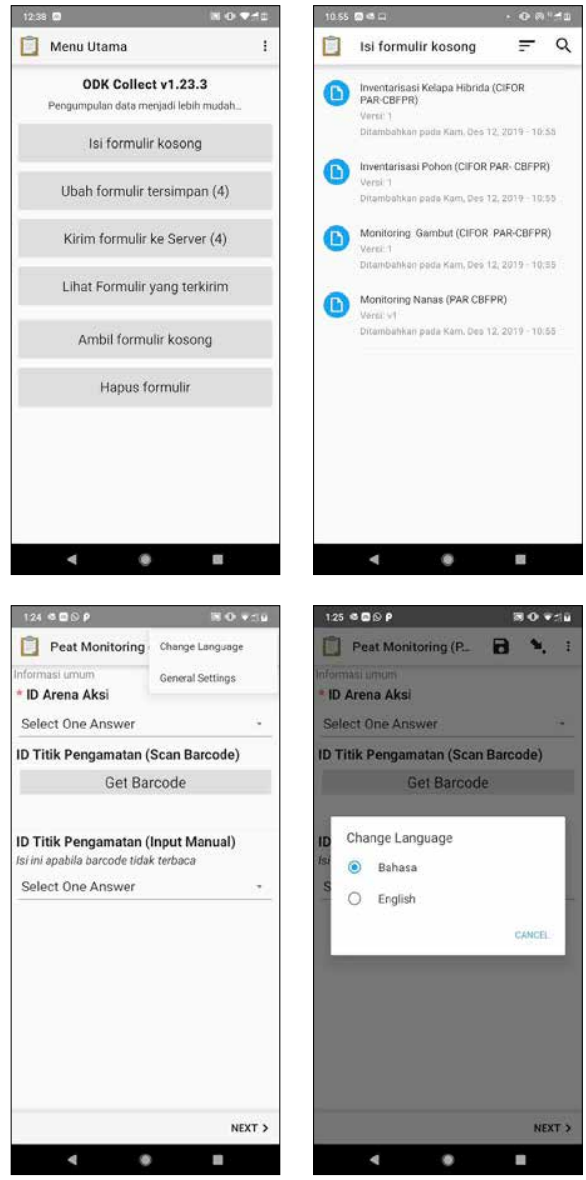
3. Untuk berpindah ke halaman berikutnya, gunakan tombol Lanjut atau Back untuk berpindah ke halaman sebelumnya. Berpindah halaman juga dapat dilakukan dengan menyapu/swipe layar ke kanan dan ke kiri.

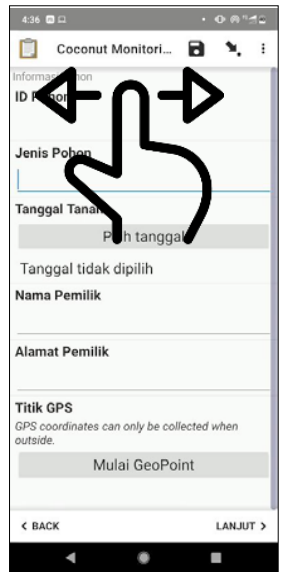

4. Untuk menyelesaikan formulir dan menyimpan ke dalam perangkat, pilih Tandai formulir ini telah siap kirim dan pilih Simpan formulir dan selesai.

Gambar

4

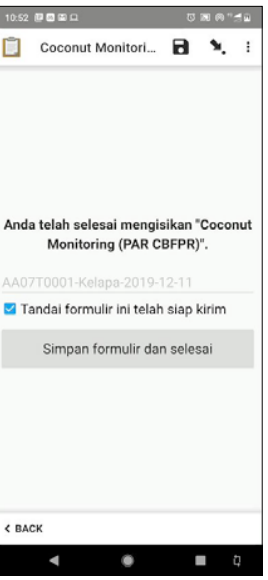

\section{Pengiriman data}

1. Dari halaman utama, pilih Kirim formulir ke Server
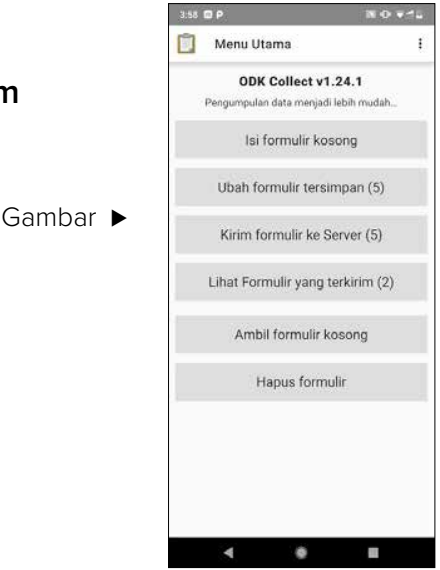
2. Serangkaian daftar isian yang sudah disimpan akan ditampilkan.

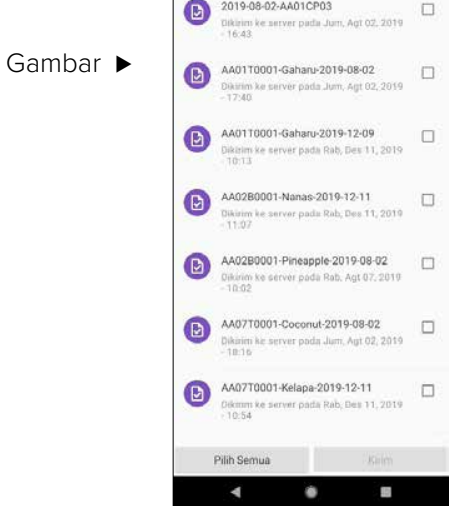

3. Pilih semua (atau pilih isian yang ingin dikirimkan), lalu pilih Kirim.

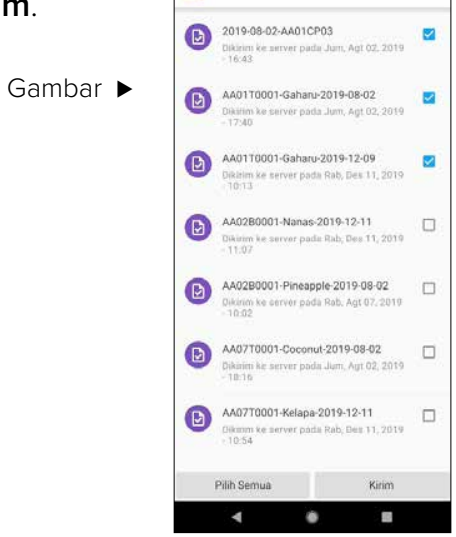

\section{Tinjauan dan pengunduhan data}

Buka perambah pada perangkat komputer atau gawai yang terhubung internet dan masukkan alamat server URL: http://koboform.cifor.org. Masukkan nama pengguna dan password. Diperlukan akses sebagai administrator untuk membuka.

Pilih tipe pemantauan yang ingin ditinjau atau diunduh.

Untuk melihat isian yang sudah dikirimkan ke server, pilih Lihat data di dalam tabel melihat masing-masing isian, atau pilih Analisis data untuk melihat hasil keseluruhan, atau pilih Unduh data untuk mengunduh dalam format XLS atau CSV atau format tabel lain. Lampiran foto dan Lokasi GPS juga tersedia di halaman ini untuk ditinjau dan diunduh. 


\subsection{PENGUKURAN DAN PENGISIAN DATA}

\subsubsection{Pemantauan gambut}

1. Pada halaman utama, pilih Isi formulir kosong dan pilih formulir [Monitoring Gambut (CIFOR PAR-CBFPR)] untuk memulai pengisian data.

Gambar

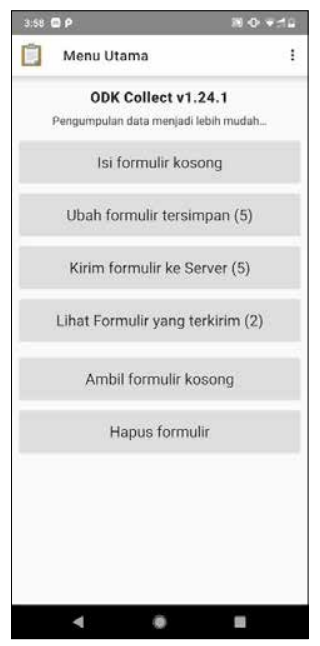

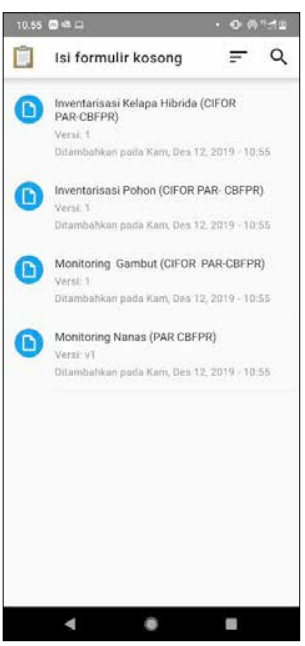

2. Halaman pertama berisi informasi identitas titik pemantauan atau sumur pantau. Silahkan pilih arena aksi dimana sumur pantau yang diukur berada dengan menggunakan menu drop-down.
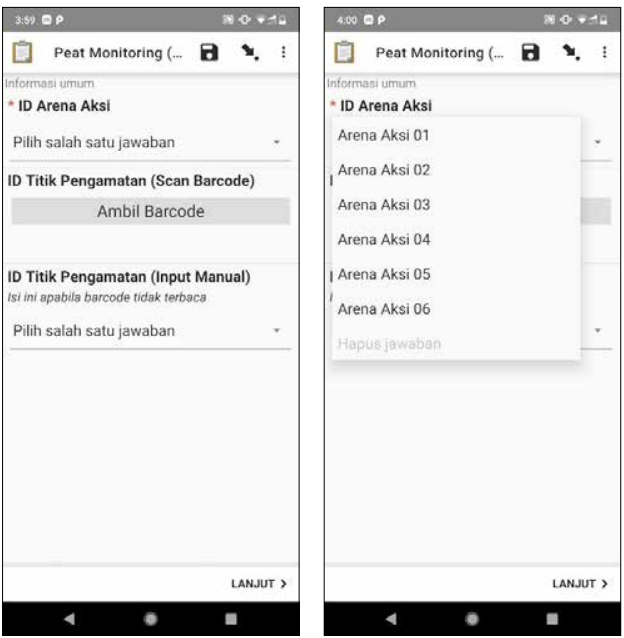
3. Periksa label ID yang terdapat pada sumur pantau dan masukkan ID sebagai proses identifikasi. Pengisian dapat dilakukan dengan memindai barcode atau menggunakan menu drop-down. Apabila pemindaian barcode berhasil, maka pengisian dengan memilih ID akan hilang. Setelah selesai, lanjutkan ke halaman berikutnya dengan memilih tombol Lanjut.

Gambar
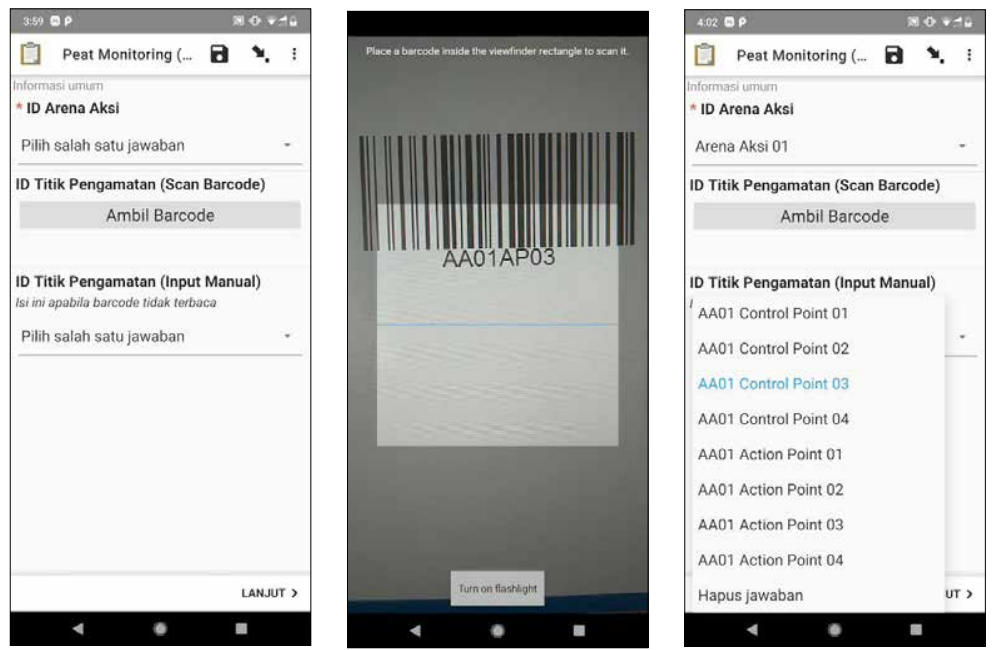

4. Pada halaman berikutnya ID Sumur Pantau yang sudah dimasukkan dan kategori sumur pantau akan muncul untuk pengecekan ulang. Masukkan titik koordinat dengan memilih Mulai GeoPoint. Apabila koordinat telah didapatkan, akan muncul informasi mengenai posisi bujur dan lintang dan nilai akurasi. Setelah selesai, lanjutkan ke halaman berikutnya dengan memilih tombol Lanjut.
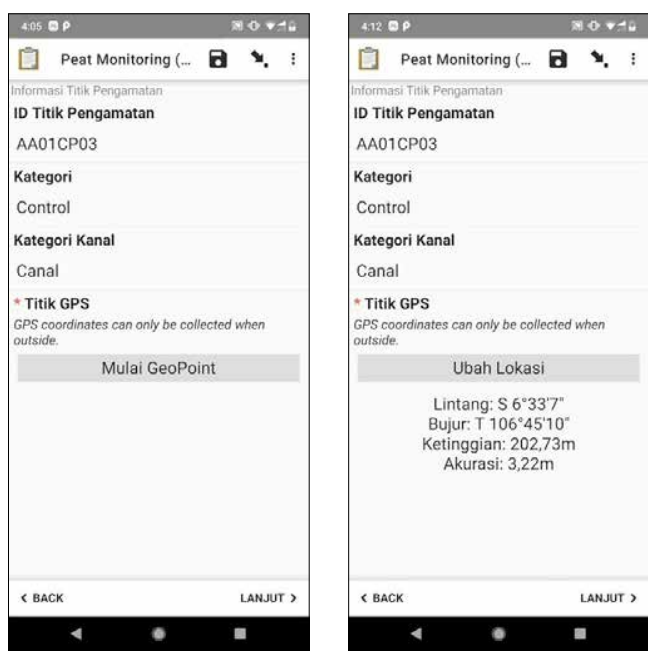
5. Halaman berikutnya berisi isian mengenai pengukuran. Masukkan Waktu Pengamatan dengan memilih waktu dan tanggal pengukuran. Waktu dan tanggal otomatis yang tertayang merupakan informasi dari perangkat gawai.

6. Lakukan pengukuran Tinggi Muka Air menggunakan tiang ukur dan masukkan nilai ukuran ke dalam isian formulir. Unit pengukuran untuk Tinggi Muka Air adalah centimeter dan dalam bentuk nilai negatif.
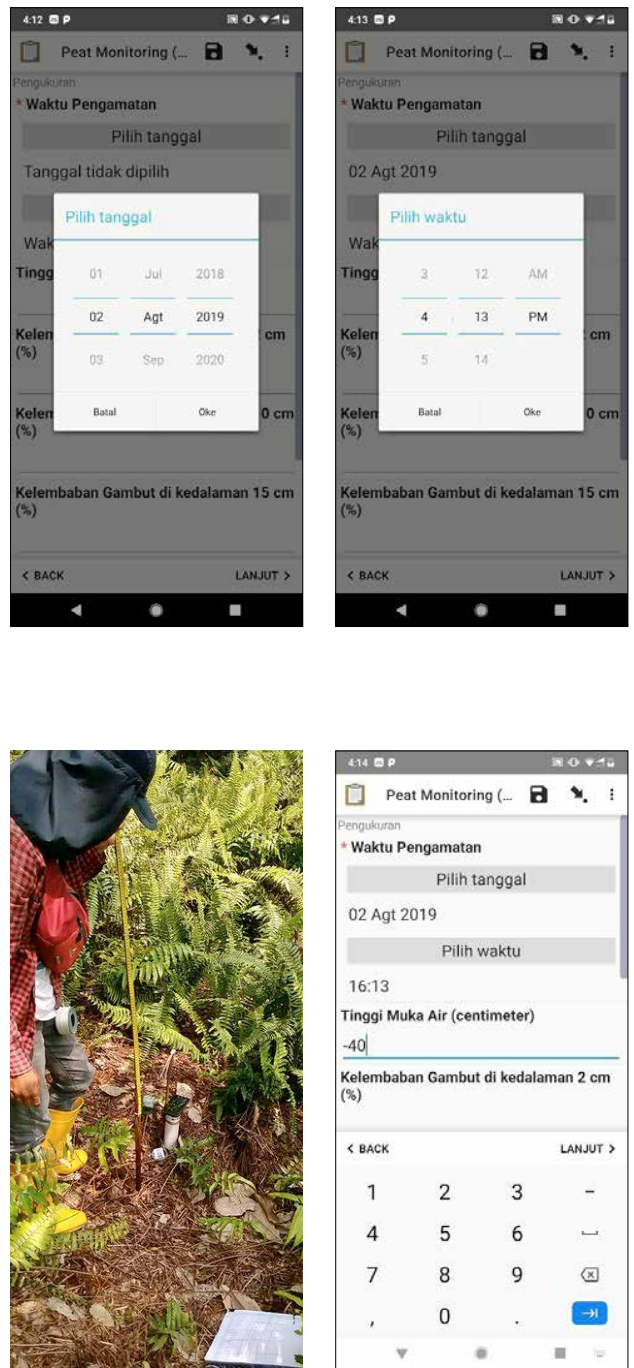

\begin{tabular}{|c|c|c|}
\hline 414 of & & $10 \times 10$ \\
\hline D $\mathrm{P}$ & tonit & y. : \\
\hline $\begin{array}{l}\text { Penoukurata } \\
* \text { Waktu }\end{array}$ & jama & \\
\hline & & \\
\hline $02 \mathrm{Agt}$ & & \\
\hline & & \\
\hline $16: 13$ & & \\
\hline Tinggi N & Air ( & \\
\hline $\begin{array}{l}\text { Kelemb } \\
\text { (\%) }\end{array}$ & Gam & an $2 \mathrm{~cm}$ \\
\hline$\angle B A C K$ & & LANuUT ? \\
\hline 1 & 2 & - \\
\hline 4 & 5 & - \\
\hline 7 & 8 & $凶$ \\
\hline , & 0 & $\rightarrow$ \\
\hline & & E $\quad 0$ \\
\hline
\end{tabular}


7. Untuk melakukan pengukuran Kelembaban Gambut, gunakan alat pengukur kelembaban pada kedalaman 2, 10, dan $15 \mathrm{~cm}$ dari permukaan tanah. Masukkan nilai hasil pengukuran pada isian formulir.

Gambar

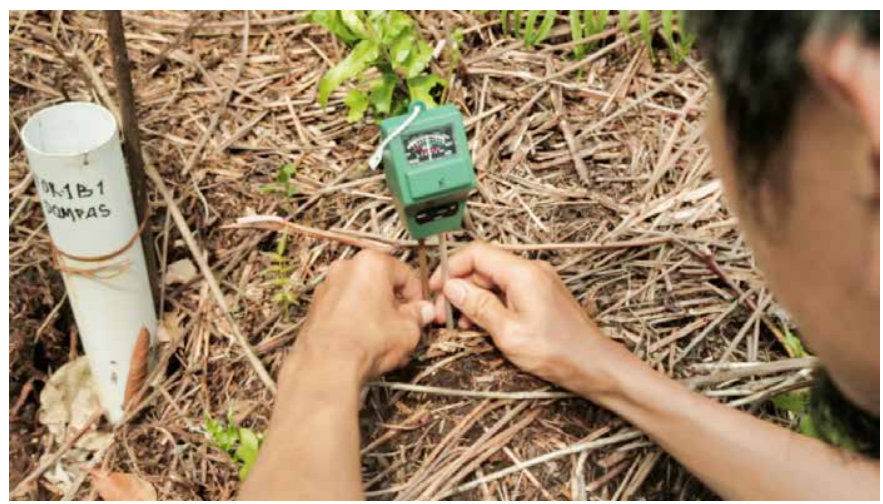

\begin{tabular}{|c|c|c|c|}
\hline \multicolumn{4}{|c|}{$4: 15 \otimes \otimes P$} \\
\hline E & \multicolumn{3}{|c|}{ Peat Monitoring (... $\mathbf{d} \mathbf{y}$ : } \\
\hline \multicolumn{4}{|l|}{-40} \\
\hline \multicolumn{4}{|c|}{$\begin{array}{l}\text { Kelembaban Gambut di kedalaman } 2 \mathrm{~cm} \\
\text { (\%) }\end{array}$} \\
\hline \multicolumn{4}{|l|}{80} \\
\hline \multicolumn{4}{|c|}{$\begin{array}{l}\text { Kelembaban Gambut di kedalaman } 10 \mathrm{~cm} \\
(\%)\end{array}$} \\
\hline \multicolumn{4}{|l|}{100} \\
\hline \multicolumn{4}{|c|}{$\begin{array}{l}\text { Kelembaban Gambut di kedalaman } 15 \mathrm{~cm} \\
(\%)\end{array}$} \\
\hline \multicolumn{4}{|l|}{100} \\
\hline \multicolumn{4}{|c|}{ Radiasi Matahari (lux) } \\
\hline$\angle B A C K$ & & & LANJUT > \\
\hline 1 & 2 & 3 & - \\
\hline 4 & 5 & 6 & - \\
\hline 7 & 8 & 9 & $凶$ \\
\hline ' & 0 & . & $\rightarrow 1$ \\
\hline & & & a \\
\hline
\end{tabular}

8. Pengukuran Radiasi Matahari dilakukan dengan menggunakan aplikasi Lux Light Meter. Masukkan nilai hasil pengukuran pada isian formulir.

Gambar -

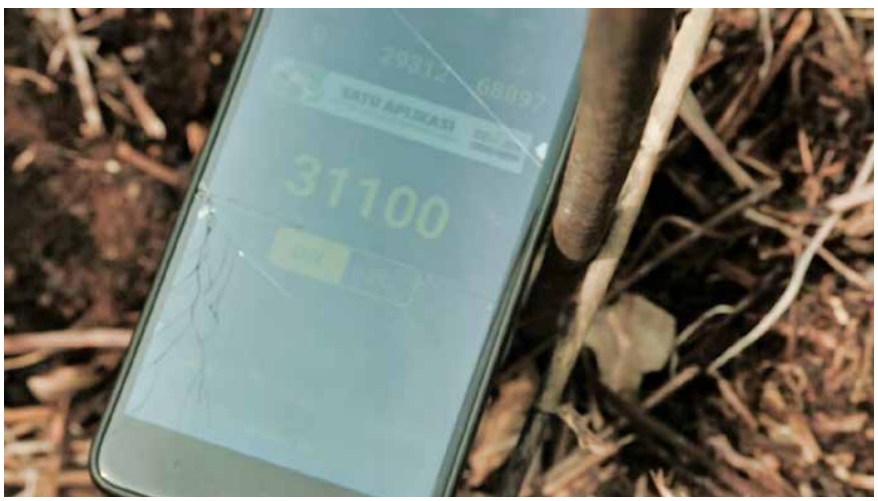

\begin{tabular}{|c|c|c|c|}
\hline $4: 16 \otimes$ & & & $0:>\leq 2$ \\
\hline[ & oni & $\ldots$ & 1. $\quad \vdots$ \\
\hline (\%) & & & \\
\hline 80 & & & \\
\hline $\begin{array}{l}\text { Kelemb } \\
(\%)\end{array}$ & Sam & keda & $10 \mathrm{~cm}$ \\
\hline 100 & & & \\
\hline $\begin{array}{l}\text { Kelemb } \\
(\%)\end{array}$ & & keda & $15 \mathrm{~cm}$ \\
\hline 100 & & & \\
\hline Radiasi & ari & & \\
\hline 31100 & & & \\
\hline Tinggi & ub & centi & \\
\hline < BACK & & & LANJUT > \\
\hline 1 & 2 & 3 & - \\
\hline 4 & 5 & 6 & $\bullet$ \\
\hline 7 & 8 & 9 & $\otimes$ \\
\hline ' & 0 & . & $\rightarrow 1$ \\
\hline & & & $=$ \\
\hline
\end{tabular}


9. Pengukuran Tinggi Tiang Subsiden dilakukan menggunakan pita ukur. Pengukuran ini dilakukan dengan mengukur tinggi dari ujung tiang hingga permukaan tanah. Pengukuran Tinggi Tiang Subsiden dilakukan dengan tenggang waktu yang lebih panjang dibandingkan dengan parameter lain, mengingat laju subsiden yang rendah. Setelah selesai, lanjutkan ke halaman berikutnya dengan memilih tombol Lanjut.

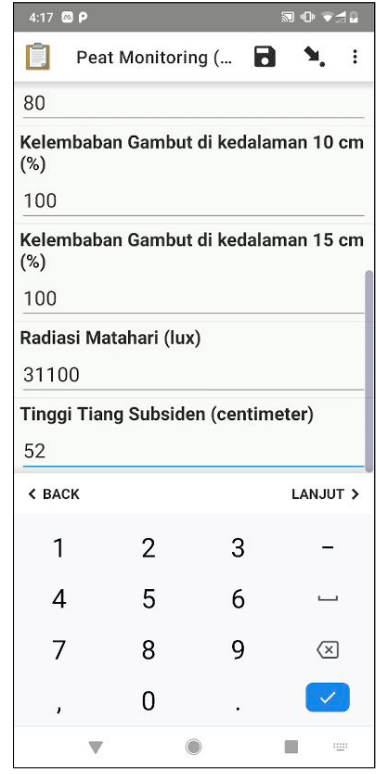
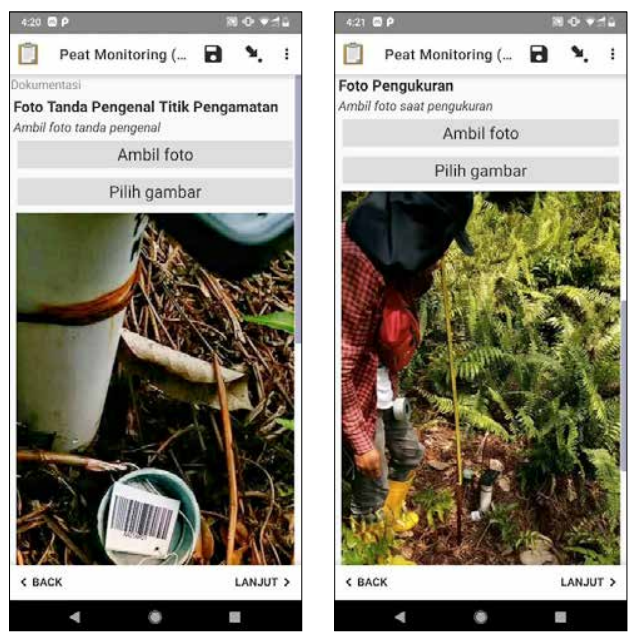

10. Halaman berikutnya berisi isian mengenai dokumentasi kegiatan. Untuk melampirkan gambar ke dalam isian formulir, gunakan tombol Ambil foto untuk mengambil gambar menggunakan kamera atau gunakan tombol Pilih gambar untuk mengambil gambar dari galeri. 
11. Terdapat isian Catatan untuk menambahkan informasi jika diperlukan. Tandai Ya pada isian Survei selesai! apabila seluruh langkah telah dijalankan. Pada halaman akhir, pilih Simpan formulir dan selesai. Tanggal pengukuran dan ID Sumur Pantau akan terlihat sebagai penamaan formulir dan pengecekan akhir.

Gambar
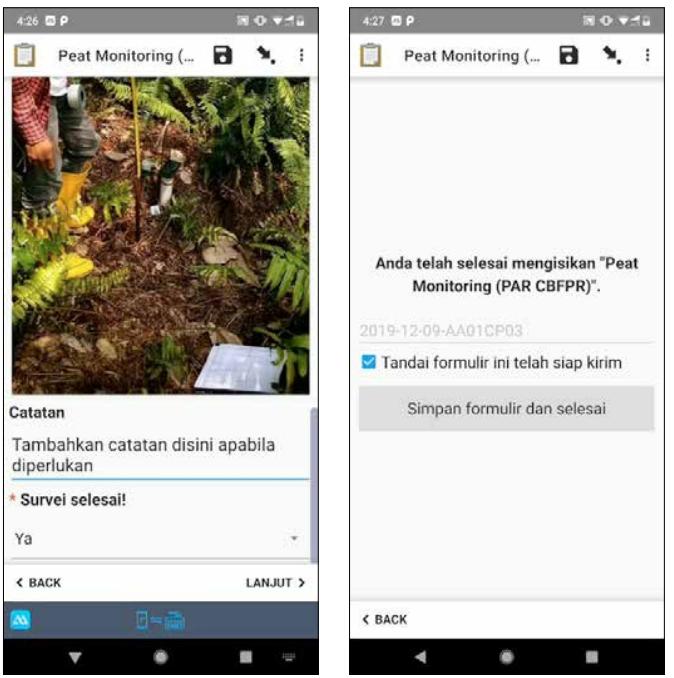

\subsubsection{Pemantauan pohon}

1. Pada halaman utama, pilih Isi formulir kosong dan pilih formulir [Inventarisasi Pohon (CIFOR PAR-CBFPR)] untuk memulai pengisian data.
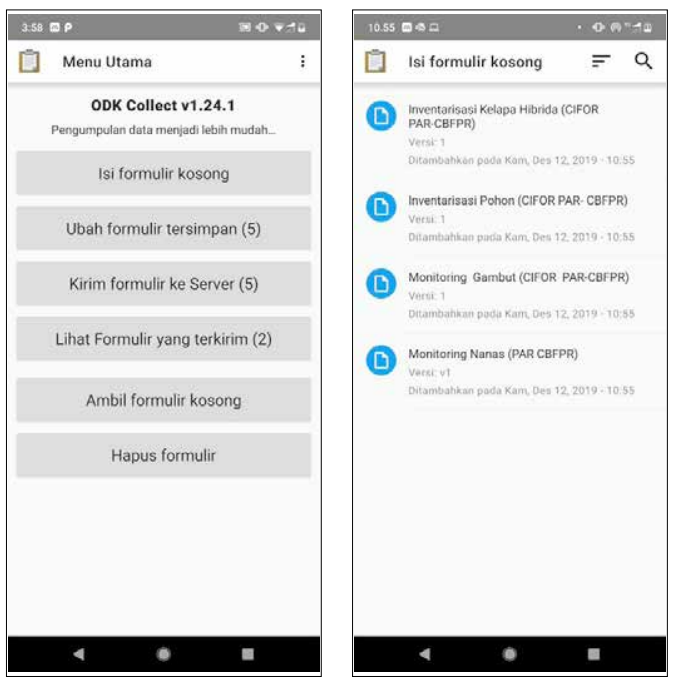
2. Halaman pertama memuat isian informasi lokasi Arena Aksi tempat pohon tersebut berada. Pilih lokasi dengan memilih pilihan Arena Aksi menggunakan menu drop-down.

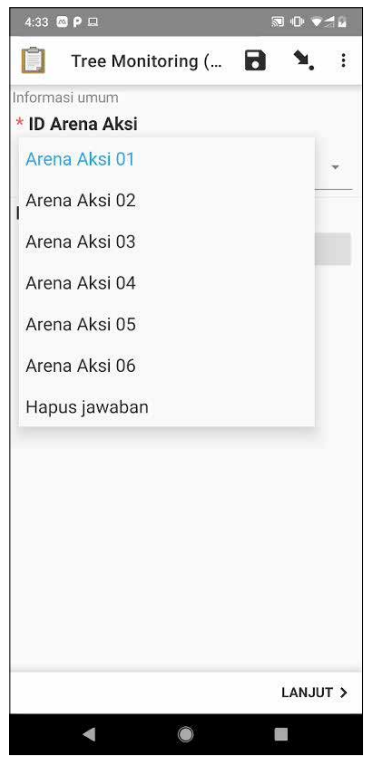

3. Pasang label barcode pada pohon dan pastikan label terpasang dengan baik. Kemudian mulai lakukan pengisian ID Pohon dengan menggunakan pemindai barcode atau apabila barcode sulit terbaca dapat dilakukan dengan cara manual, yaitu dengan mengetikkan barcode yang tertera pada label. Setelah selesai, lanjutkan ke halaman berikutnya dengan memilih tombol Lanjut.
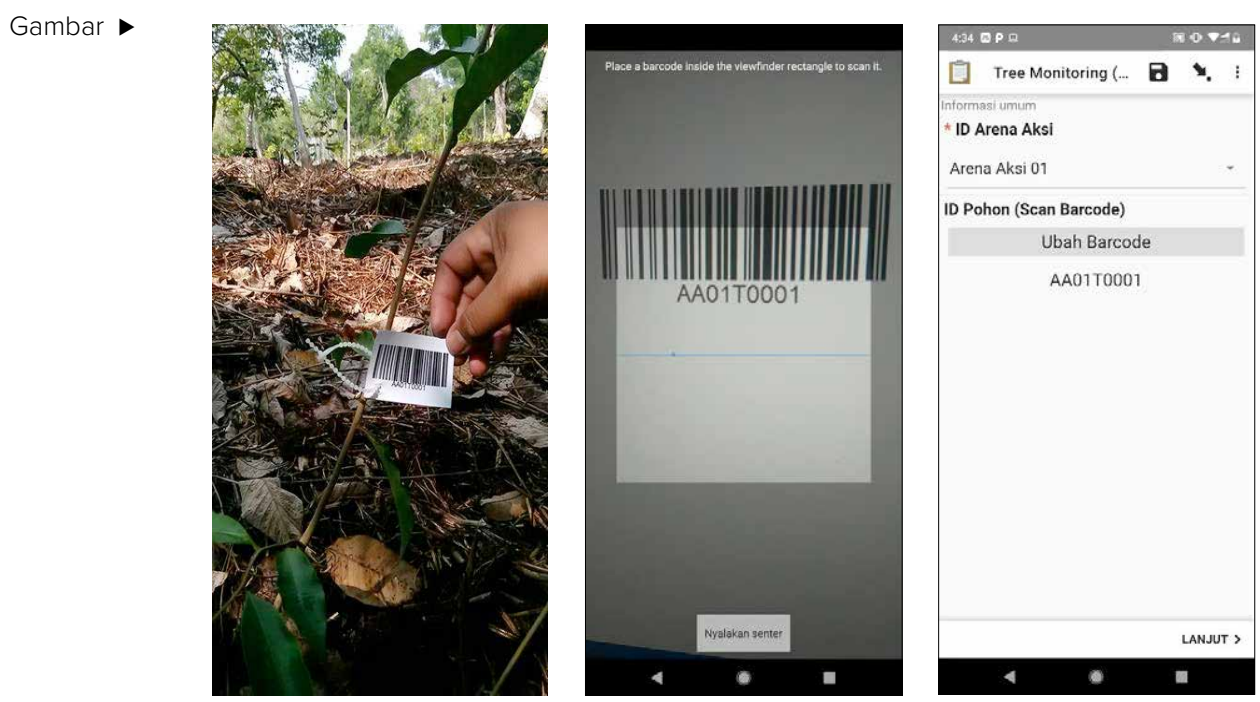
4. Halaman ini memuat isian mengenai informasi pohon yang ditanam, yaitu jenis pohon, tanggal penanaman, dan lokasi penanaman. ID Pohon akan ditampilkan pada sisi atas halaman untuk pengecekan ulang. Lakukan pengisian jenis pohon dengan menggunakan papan ketik dan masukkan tanggal penanaman dengan memilih tanggal. Masukkan titik koordinat dengan memilih Mulai GeoPoint. Apabila koordinat telah didapatkan, akan muncul informasi mengenai posisi bujur dan lintang dan nilai akurasi. Setelah selesai, lanjutkan ke halaman berikutnya dengan memilih tombol Lanjut.

\section{Gambar}

5. Halaman berikutnya memuat isian informasi hasil pengukuran. Waktu dan tanggal pengukuran akan otomatis terisi dengan mengambil informasi tanggal dari perangkat gawai. Lakukan pengukuran tinggi pohon dengan menggunakan pita ukur dan masukkan nilai hasil pengukuran ke dalam formulir isian. Unit yang digunakan untuk isian tinggi pohon adalah meter. Pada tahap awal penanaman, pengukuran pertumbuhan hanya menggunakan pendekatan tinggi pohon. Saat pohon telah tumbuh besar, informasi mengenai diameter pohon dapat ditambahkan pada formulir isian yang telah disiapkan. Setelah selesai, lanjutkan ke halaman berikutnya dengan memilih tombol Lanjut.
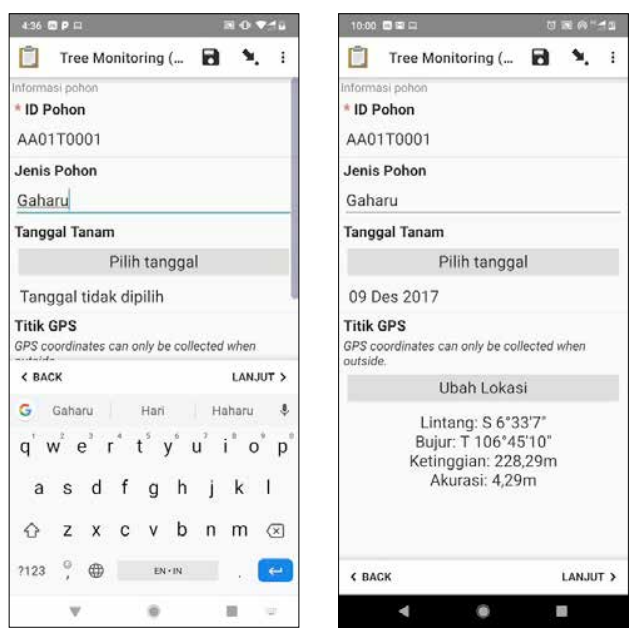

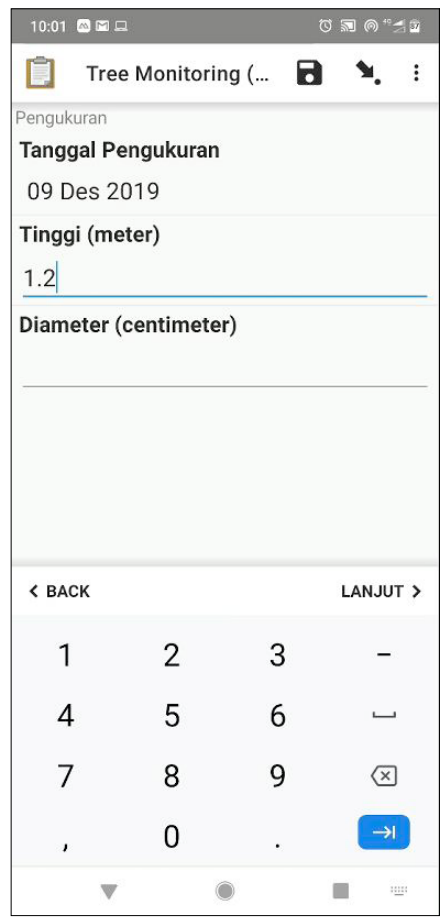


6. Halaman ini berisi isian mengenai dokumentasi kegiatan. Lampirkan gambar label ID Pohon, gambar keseluruhan pohon, dan gambar daun. Untuk melampirkan gambar ke dalam isian formulir, gunakan tombol Ambil foto untuk mengambil gambar menggunakan kamera atau gunakan tombol Pilih gambar untuk mengambil gambar dari galeri.
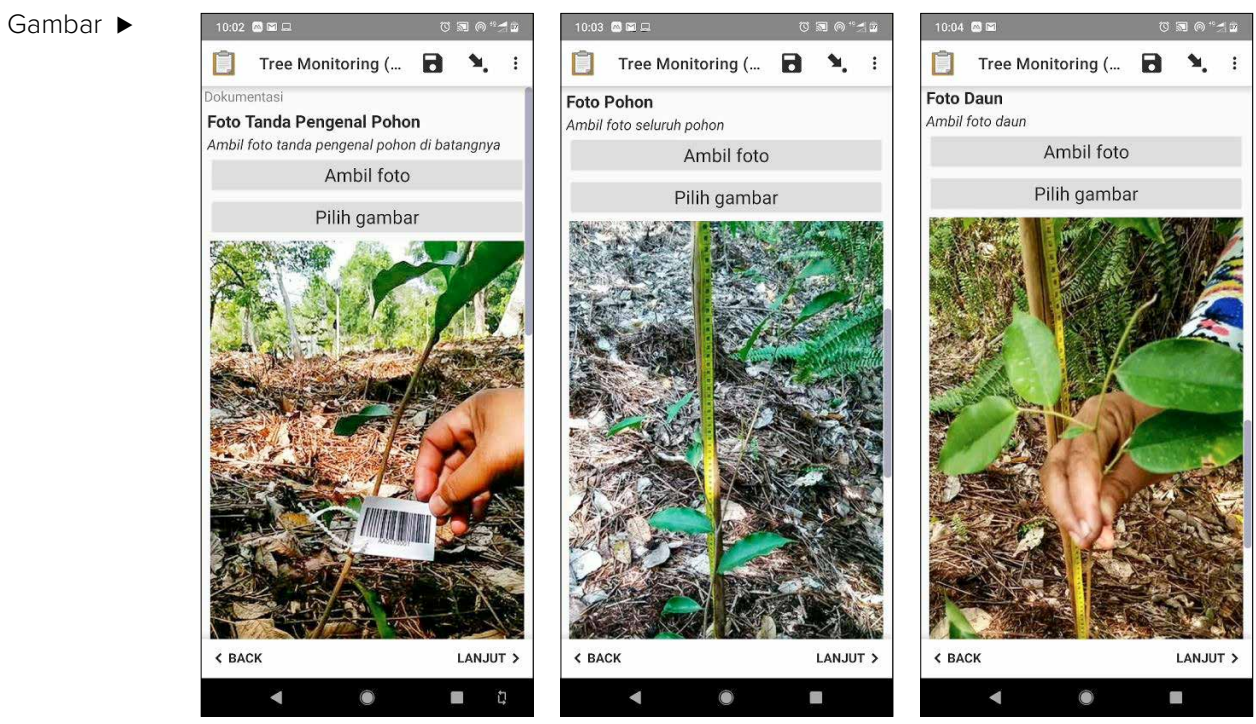

7. Pada halaman berikutnya, terdapat isian mengenai Perlakuan apabila terdapat perlakuan berbeda terhadap pohon tersebut. Informasi tambahan dapat dituliskan pada isian Catatan jika diperlukan. Tandai Ya pada isian Survei selesai! apabila seluruh langkah telah dijalankan. Pada halaman akhir, pilih Simpan formulir dan selesai. Informasi ID Pohon, Jenis Pohon dan Tanggal Pengukuran akan muncul sebagai penamaan formulir dan pengecekan akhir.
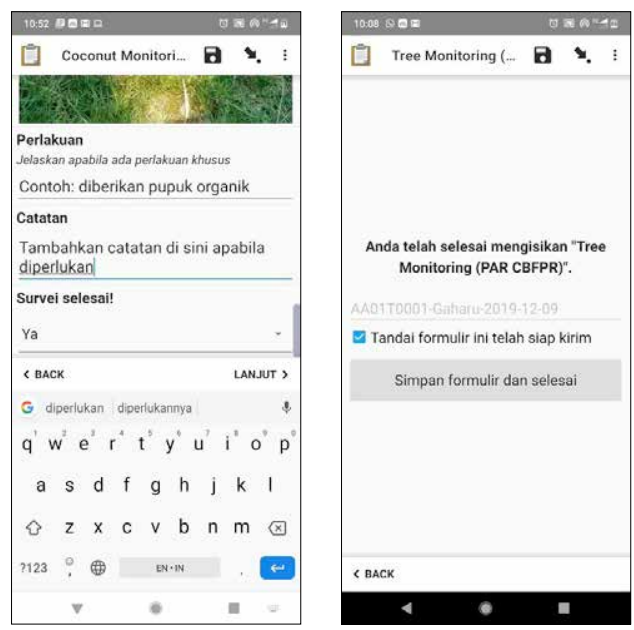


\subsubsection{Pemantauan kelapa}

1. Pada halaman utama, pilih Isi formulir kosong dan pilih formulir [Inventarisasi Kelapa Hibrida (CIFOR PAR-CBFPR)] untuk memulai pengisian data.
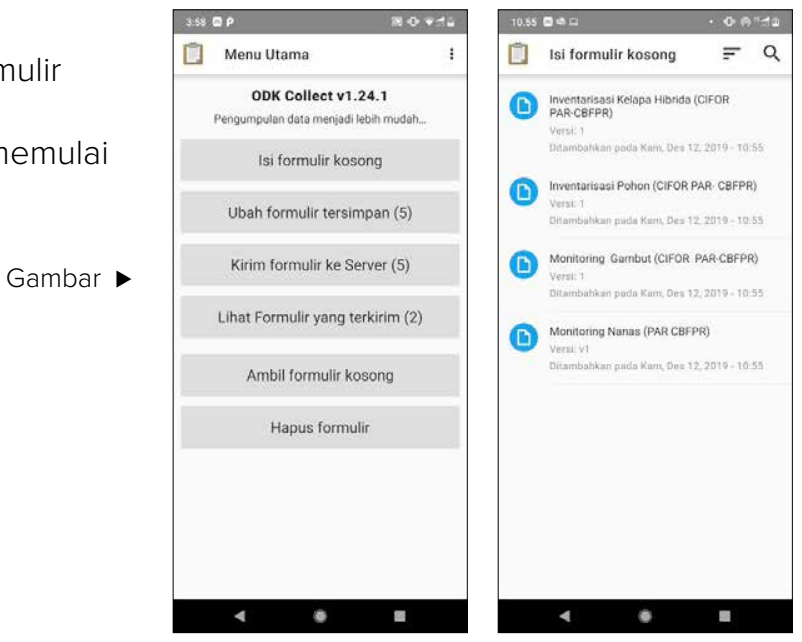

2. Halaman pertama memuat isian informasi identitas pohon kelapa. Silahkan pilih Arena Aksi tempat pohon kelapa yang diukur berada. Untuk penanaman pohon kelapa, mengingat seluruh penanaman dilakukan di Arena Aksi 7, maka isian akan otomatis menampilkan Arena Aksi 7. Pasang label barcode berisi ID Pohon Kelapa dan lakukan pemindaian barcode untuk mengisi isian ID Pohon Kelapa. Isian secara manual juga dimungkinkan dengan mengetik ID Pohon Kelapa apabila pemindaian barcode gagal. Setelah
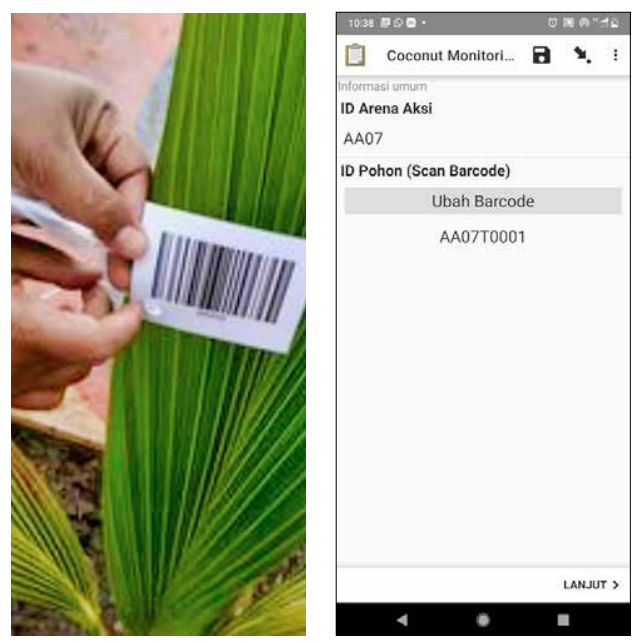
selesai, lanjutkan ke halaman berikutnya dengan memilih tombol Lanjut. 
3. Halaman berikutnya memuat isian formulir dengan informasi jenis pohon, tanggal penanaman nama pemilik, alamat pemilik dan titik koordinat. Mengingat formulir ini dikhususkan untuk tanaman kelapa, maka isian formulir secara otomatis menampilkan kelapa sebagai jenis pohon. ID Pohon yang telah dimasukkan di halaman sebelumnya tertera di bagian atas halaman sebagai bagian dari pengecekan ulang. Lengkapi isian terkait informasi mengenai tanaman dan pemiliknya dengan bertanya kepada pemilik tanaman. Masukkan titik koordinat dengan memilih Mulai GeoPoint. Apabila koordinat telah didapatkan, akan muncul informasi mengenai posisi bujur dan lintang dan nilai akurasi. Setelah selesai, lanjutkan ke halaman berikutnya dengan memilih tombol Lanjut.

\section{Gambar}
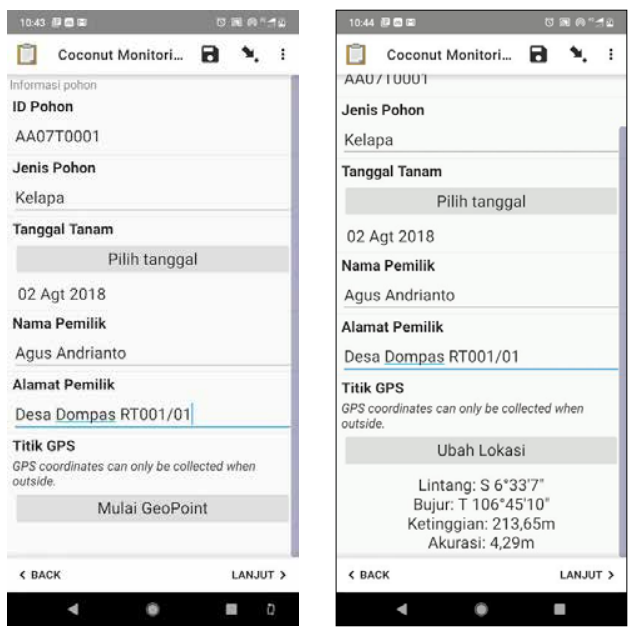

4. Halaman berikutnya memuat isian informasi hasil pengukuran. Waktu dan tanggal pengukuran akan otomatis terisi dengan mengambil informasi tanggal dari perangkat gawai. Lakukan pengukuran tinggi pohon dengan menggunakan pita ukur dan masukkan nilai hasil pengukuran ke dalam formulir isian. Unit yang digunakan untuk isian tinggi pohon adalah meter. Untuk tahap awal penanaman, pengukuran pertumbuhan hanya menggunakan pendekatan tinggi tanaman. Jika tanaman telah tumbuh besar, informasi mengenai diameter tanaman dapat ditambahkan pada formulir isian yang telah disiapkan. Setelah selesai, lanjutkan ke halaman berikutnya dengan memilih tombol Lanjut.

\section{Gambar}

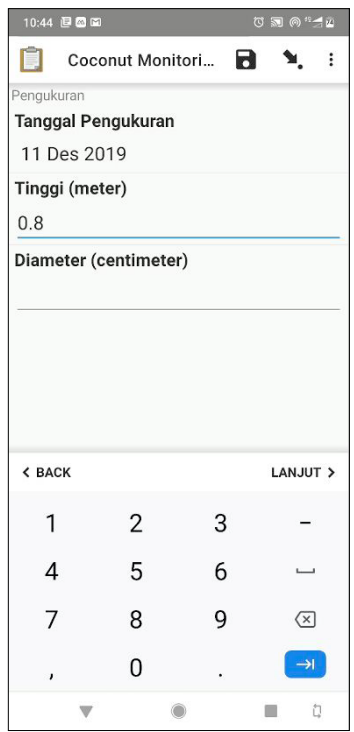


5. Halaman ini berisi isian mengenai dokumentasi kegiatan. Lampirkan gambar label ID Pohon dan gambar keseluruhan pohon. Untuk melampirkan gambar ke dalam isian formulir, gunakan tombol Ambil foto untuk mengambil gambar menggunakan kamera atau gunakan tombol Pilih gambar untuk mengambil gambar dari galeri. Setelah selesai, lanjutkan ke halaman berikutnya dengan memilih tombol Lanjut.
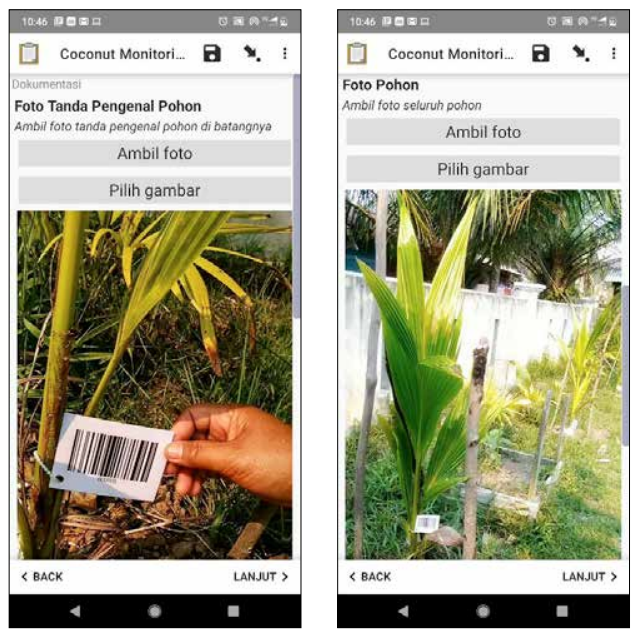

6. Pada halaman berikutnya, terdapat isian mengenai Perlakuan apabila terdapat perlakuan berbeda terhadap pohon tersebut. Informasi tambahan dapat dituliskan pada isian Catatan jika diperlukan. Tandai Ya pada isian Survei selesai apabila seluruh langkah telah dijalankan. Pada halaman akhir, pilih Simpan formulir dan selesai. Informasi ID Pohon, Jenis Pohon dan Tanggal Pengukuran akan muncul sebagai penamaan formulir dan pengecekan akhir.
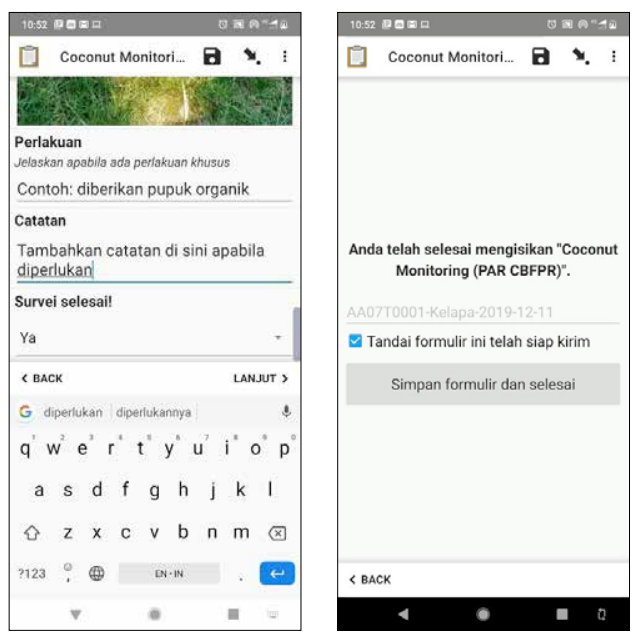


\subsubsection{Pemantauan nanas}

1. Pada halaman utama, pilih Isi formulir kosong dan pilih formulir [Monitoring Nanas (CIFOR PAR-CBFPR)] untuk memulai pengisian data.

Gambar
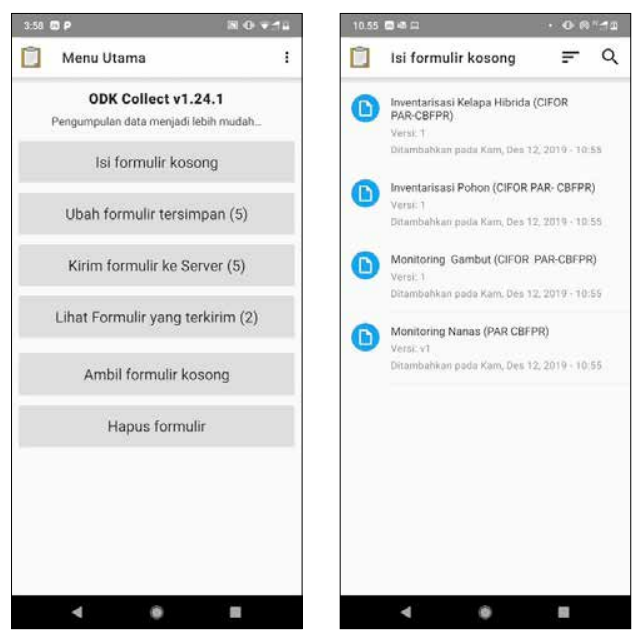

2. Halaman pertama memuat isian informasi blok tanam Nanas. Pilih lokasi Arena Aksi dengan memilih pilihan Arena Aksi menggunakan menu drop-down. Mengingat penanaman nanas dilakukan pada Arena Aksi 02 dan 03, maka hanya terdapat dua pilihan Arena Aksi. Selanjutnya masukkan ID Blok Tanam dengan menggunakan pemindai barcode atau apabila barcode sulit terbaca dapat dilakukan dengan cara manual dengan mengetikkan barcode yang tertera pada label. Setelah selesai, lanjutkan ke halaman berikutnya dengan memilih tombol Lanjut.

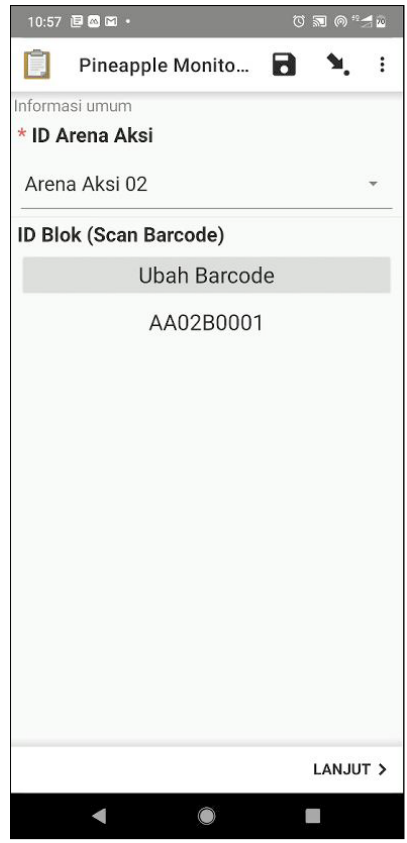


3. Halaman berikutnya memuat isian formulir mengenai informasi jenis tanaman, tanggal penanaman, nama kelompok penggarap yang bertanggung jawab terhadap blok tanam, dan titik koordinat. Mengingat formulir ini khusus untuk tanaman Nanas, maka isian formulir secara otomatis menuliskan Nanas sebagai jenis tanaman. ID Blok Tanam yang telah dimasukkan di halaman sebelumnya tertera di bagian atas halaman sebagai bagian dari pengecekan ulang. Masukkan titik koordinat dengan memilih Mulai GeoPoint. Apabila koordinat telah didapatkan, akan muncul informasi mengenai posisi bujur dan lintang dan nilai akurasi. Setelah selesai, lanjutkan ke halaman berikutnya dengan memilih tombol Lanjut.
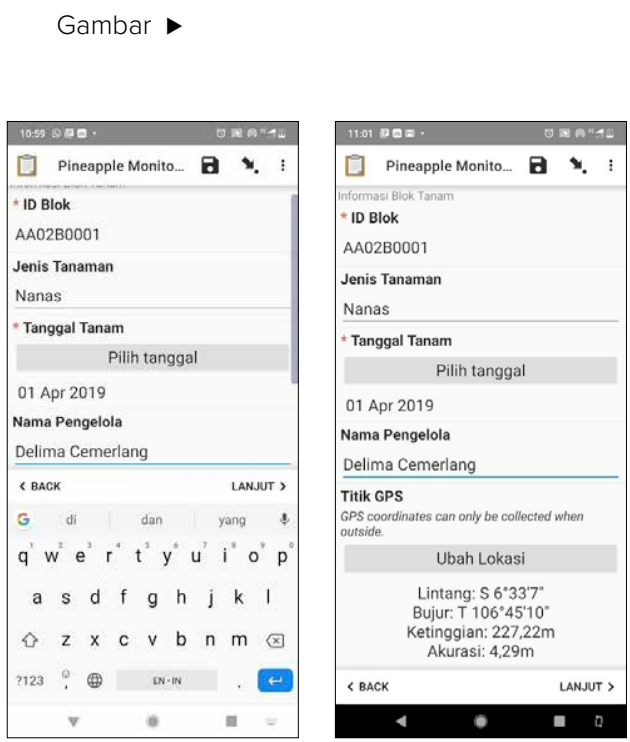

4. Halaman berikutnya memuat isian informasi hasil penghitungan. Waktu dan tanggal pengukuran akan otomatis terisi dengan mengambil informasi tanggal dari perangkat gawai. Lakukan penghitungan jumlah tanaman nanas dan jumlah buah dalam satu blok tanam lalu masukkan nilai hasil penghitungan ke dalam formulir isian. Setelah selesai, lanjutkan ke halaman berikutnya dengan memilih tombol Lanjut.

\section{Gambar}

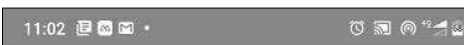

[ 1 Pineapple Monito... 으. Informasi Blok Tanam

* Tanggal Monitoring

11 Des 2019

* Jumlah Tanaman

3868

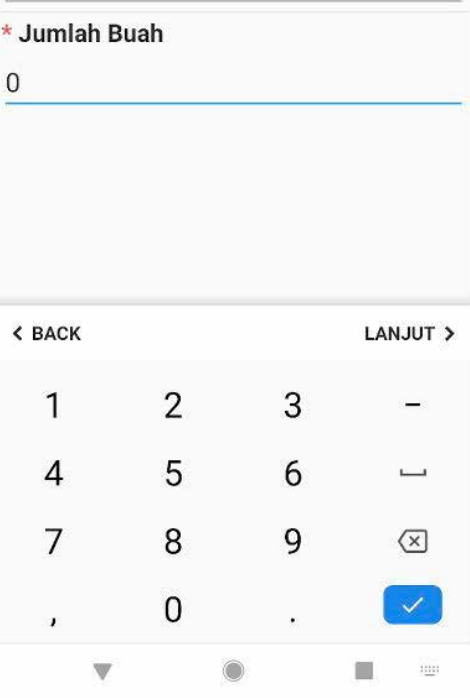


5. Halaman ini memuat isian mengenai dokumentasi kegiatan. Lampirkan gambar label ID Blok Tanam, gambar salah satu tanaman nanas yang dapat mewakili kondisi tanaman yang lain, dan gambar keseluruhan lanskap blok tanam. Untuk melampirkan gambar ke dalam isian formulir, gunakan tombol Ambil foto untuk mengambil gambar menggunakan kamera atau gunakan tombol Pilih gambar untuk mengambil gambar dari galeri. Setelah selesai, lanjutkan ke halaman berikutnya dengan memilih tombol Lanjut.
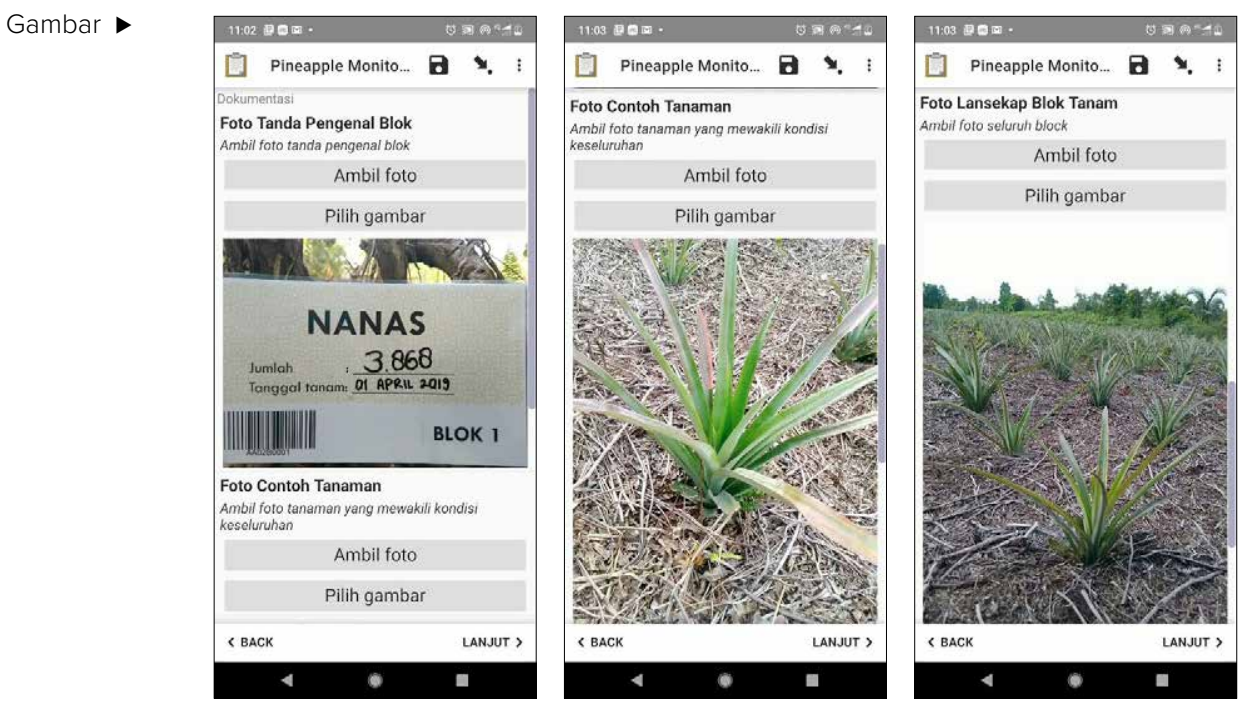

6. Pada halaman berikutnya, terdapat isian mengenai Perlakuan apabila terdapat perlakuan berbeda terhadap pohon tersebut. Informasi tambahan dapat dituliskan pada isian Catatan jika diperlukan. Tandai Ya pada isian Survei selesai! apabila seluruh langkah telah dijalankan. Pada halaman akhir, pilih Simpan formulir dan selesai. Informasi ID Blok Tanam, Jenis Tanaman dan Tanggal Pemantauan akan muncul sebagai penamaan formulir dan pengecekan akhir.
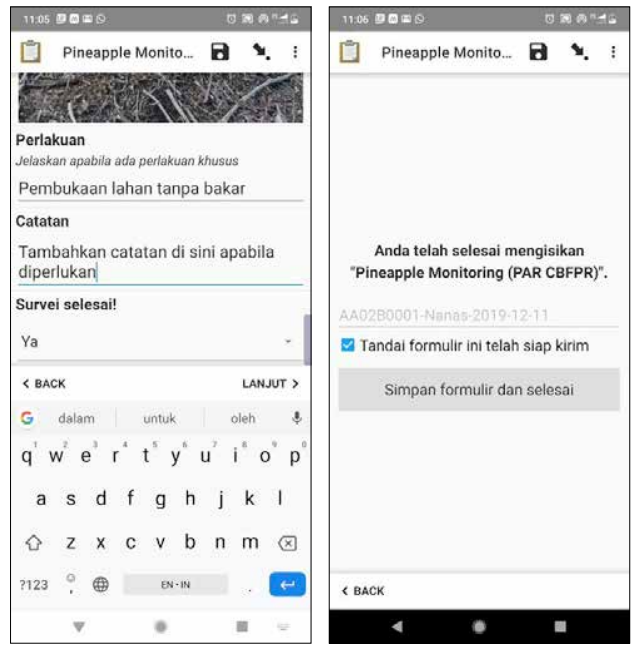


\subsection{VISUALISASI DATA}

Visualisasi dan interpretasi data menjadi hal penting dalam memahami kondisi terkini. Salah satu perangkat lunak yang populer digunakan untuk hal tersebut adalah Microsoft Power Bl. Platform pemantauan CO-PROMISE menggunakan Microsoft Power Bl untuk menampilkan hasil pemantauan melalui online dashboard. Perangkat lunak ini menyediakan tampilan yang dapat disesuaikan dengan kebutuhan dan memiliki koneksi langsung ke basis data KoBo Toolbox, sehingga data dapat langsung ditampilkan sesaat setelah hasil pengukuran dikirimkan ke server.
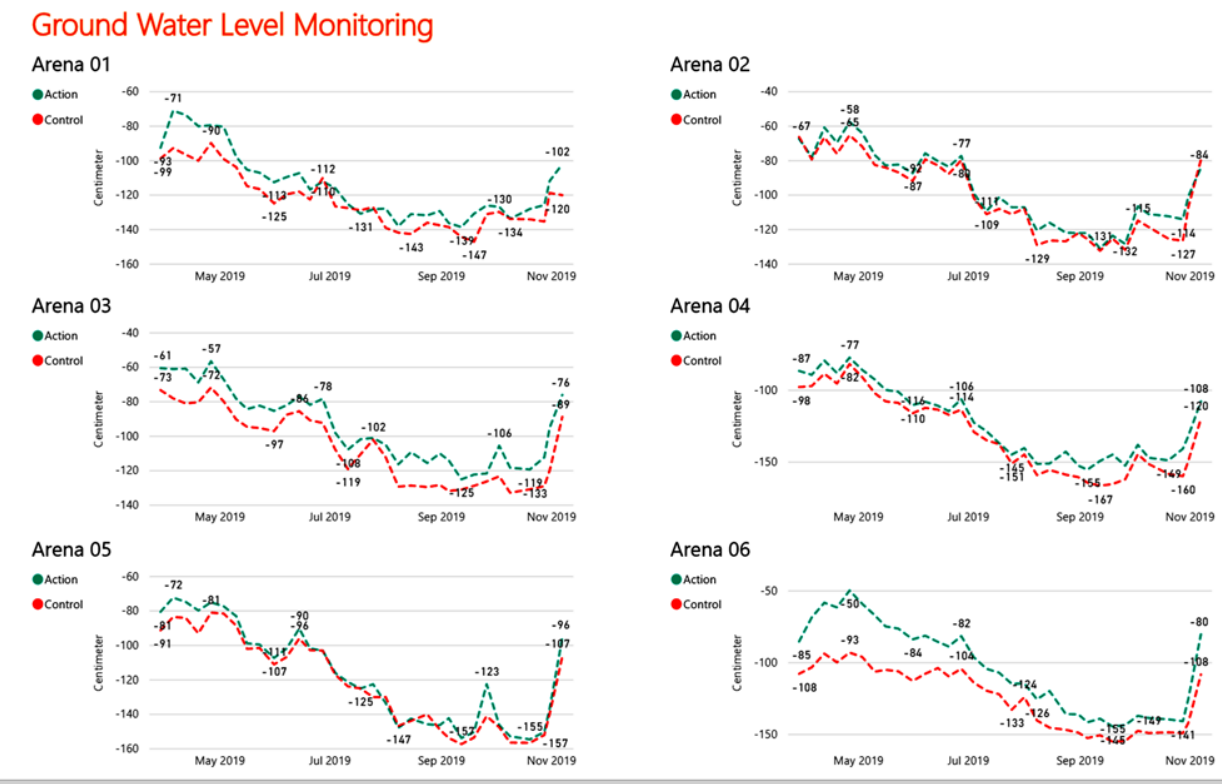

\section{Gambar 9.6 Tangkapan layar dashboard pemantauan gambut}

https://www.cifor.org/fire-and-peatland-restoration/research/monitoring-of-theaction-arena/ 


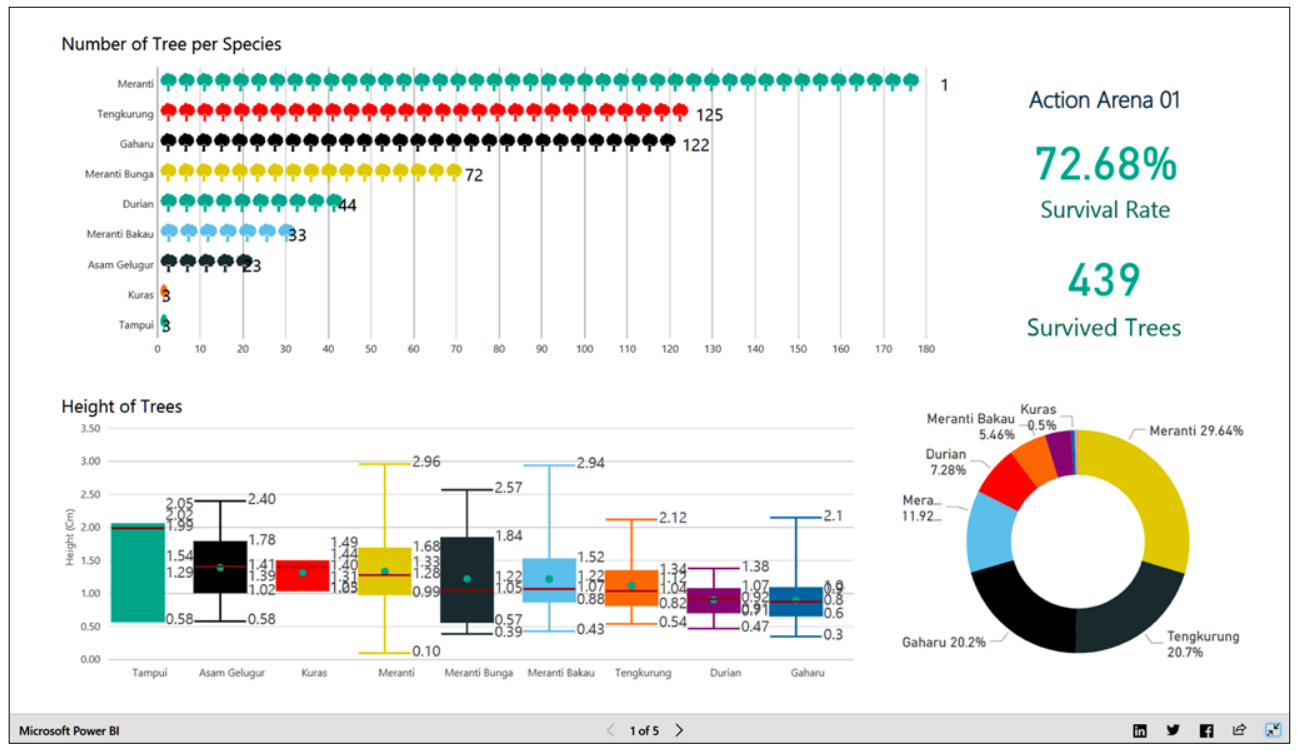

Gambar 9.7 Tangkapan layar dashboard pemantauan pohon

https://bit.ly/treemonitoring

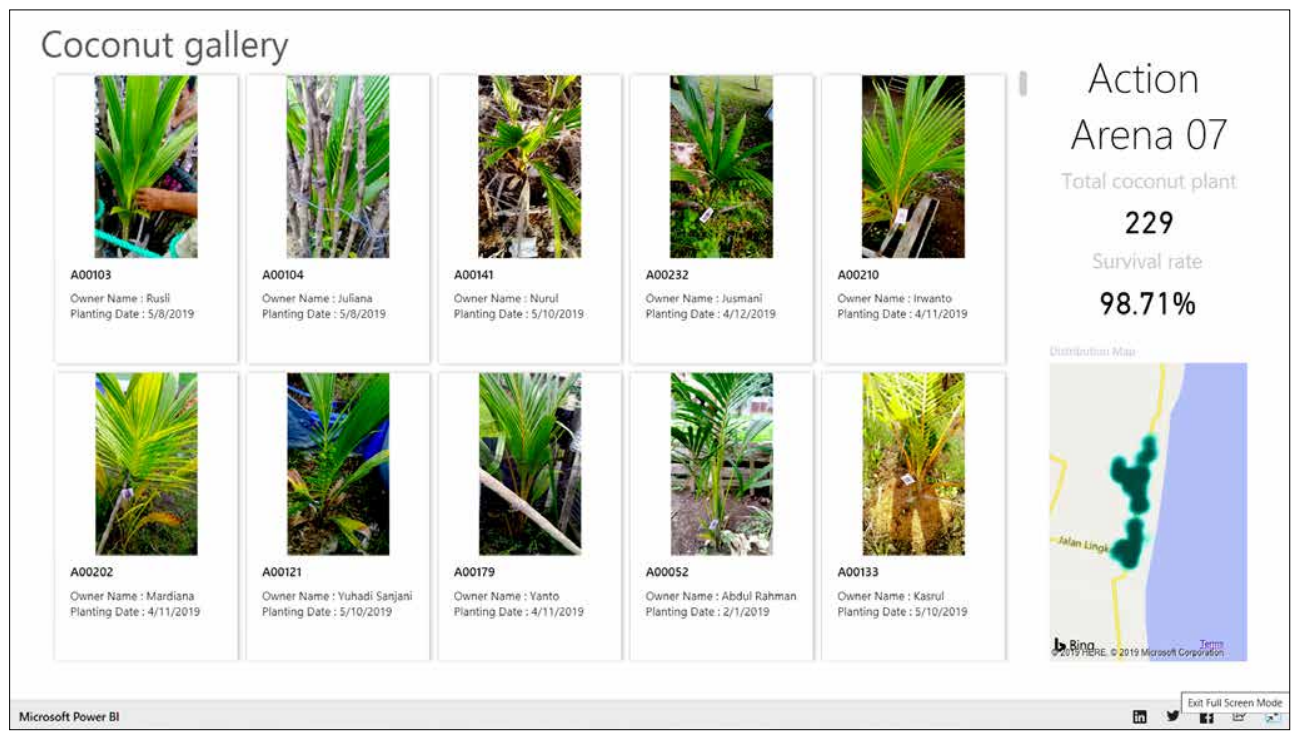

Gambar 9.8 Tangkapan layar dashboard pemantauan kelapa

https://bit.ly/coconutmonitoring 


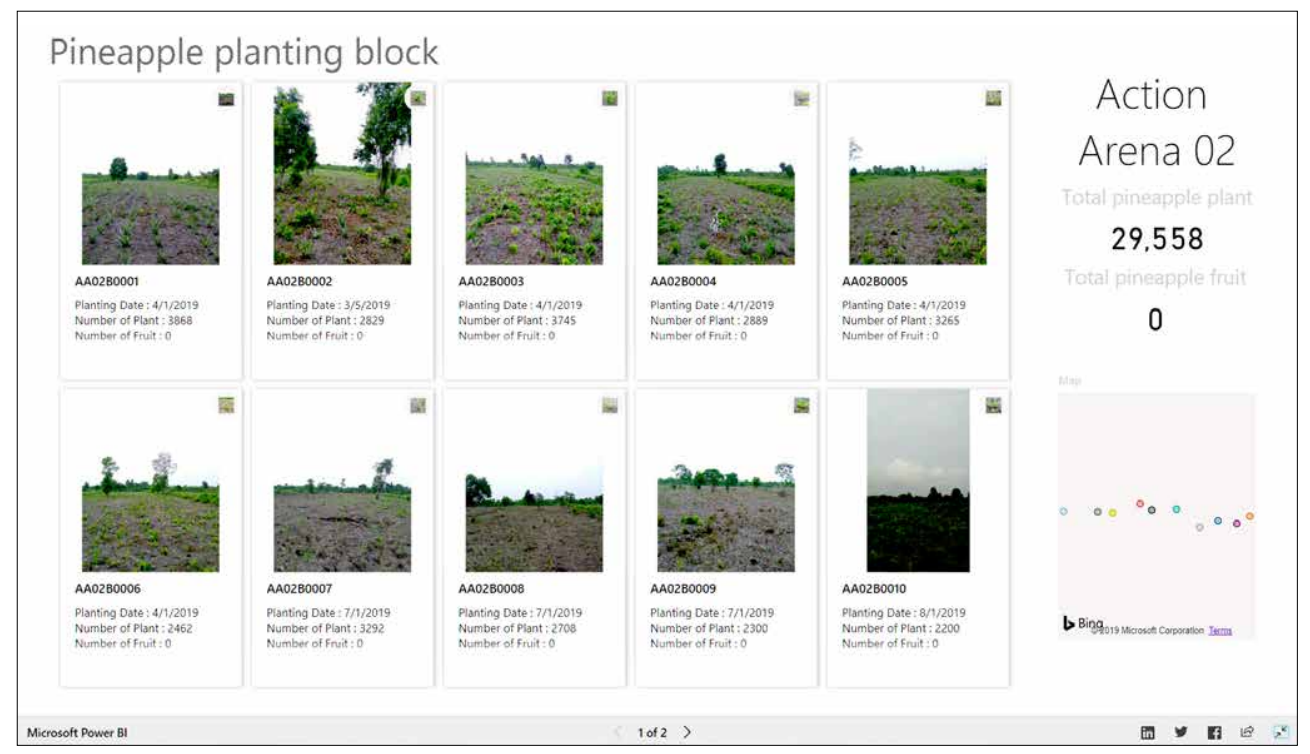

Gambar 9.9 Tangkapan layar dashboard pemantauan nanas

https://bit.ly/pineapplemonitoring

\subsection{JAMINAN KUALITAS DAN KONTROL KUALITAS}

Jaminan Kualitas (Quality Assurance) dan Kontrol Kualitas (Quality Control) merupakan proses memastikan integritas data dan meminimalisir kesalahan yang mungkin terjadi. Jaminan kualitas merupakan upaya aktif untuk menjaga integritas data. Hal ini dilakukan dengan melakukan proses pelatihan, menyediakan dokumen panduan langkah-langkah pemantauan, menyediakan penjelasan pada formulir isian, melakukan pemeriksaan terhadap hasil pemantauan secara berkala, melakukan upaya pencatatan manual sebagai bahan perbandingan apabila ditemukan kejanggalan data dan juga sebagai cadangan data, melakukan dokumentasi gambar, dan menjaga komunikasi antara pengelola data dengan masyarakat yang melakukan pengukuran. Untuk menjamin kualitas data yang masuk, diperlukan upaya terus menerus untuk menjaga, mendeteksi, dan memperbaiki apabila terjadi kesalahan pada proses pemantauan ini.

Kontrol kualitas merupakan upaya reaktif yang diintegrasikan ke dalam sistem untuk mencegah dan mendeteksi kesalahan dalam proses pemantauan. Berbagai upaya menjaga kualitas data yang dimasukkan antara lain dilakukan dengan menggunakan ID yang unik untuk setiap subyek pengukuran, menetapkan tipe data yang perlu 
dimasukkan, mengatur akurasi minimum dalam memasukkan koordinat, menerapkan pertanyaan yang wajib diisi, dan menerapkan rentang nilai batas wajar dalam memasukkan hasil pengukuran. Deteksi kesalahan secara otomatis ketika memasukkan hasil pengukuran akan mencegah pencatat data menuju proses selanjutnya sebelum dilakukan perbaikan. Seluruh upaya ini dilakukan untuk mencegah kesalahan pencatat data dalam memasukkan hasil pengukuran.

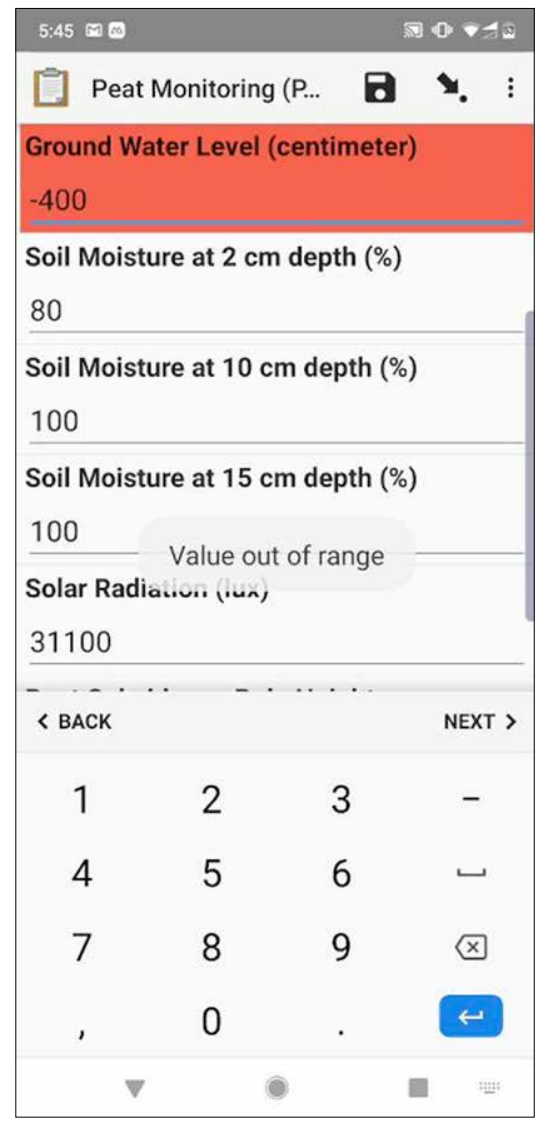

Gambar 9.10 Contoh kesalahan data yang terdeteksi apabila nilai yang dimasukkan berada di luar rentang nilai batas wajar 


\subsection{KETERBATASAN}

- Sistem pemantauan ini tetap membutuhkan pencatat data untuk datang ke lokasi dan melakukan pengukuran.

- Mengingat seluruh penyimpanan data berada di server CIFOR, maka pemanfaatan platform ini masih terbatas pada aktivitas yang berkaitan dengan CIFOR. Namun platform ini sangat terbuka untuk dimodifikasi agar dapat dipakai untuk kepentingan berbagai pihak.

- Akurasi koordinat GPS yang dimiliki oleh perangkat gawai saat ini masih relatif rendah. Meskipun ODK Collect telah menerapkan metode GPS averaging dan menerapkan batas minimum akurasi hingga tiga meter, dengan kepadatan tanaman yang ada, hasil pengukuran masih terlihat tersebar dan tidak menunjukkan pola terstruktur.

\subsection{PUSTAKA}

Ritzema H, Limin S, Kusin K, Jauhiainen J, dan Wösten, H. 2014. Canal blocking strategies for hydrological restoration of degraded tropical peatlands in Central Kalimantan, Indonesia. Catena, 114: 11-20. 

Ide, narasi dan argumentasi dalam mencegah bencana alam dan restorasi ekosistem berfokus pada peningkatan kesadaran dan partisipasi semua pihak. Riset konvensional membantu memahami sistem sosio-ekologis dan interaksinya. Akan tetapi, pemerintah, masyarakat dan donor menginginkan riset yang membawa perubahan. Kebutuhan akan perubahan sangat tinggi. Riset yang dilakukan dengan partisipasi penuh dan berorientasi pada aksi merupakan jawaban. Riset Aksi Partisipatif (RAP) dirancang untuk membawa perubahan nyata di lapangan. RAP bersifat transdisiplin yang mengintegrasikan pendekatan ragam disiplin ilmu pengetahuan dan kearifan lokal maupun global (local and global wisdoms). Buku ini memberikan pemahaman tentang konsep, landasan filosofis dan langkah implementasi RAP, yang dilengkapi dengan elaborasi pencegahan kebakaran dan restorasi gambut berbasis masyarakat yang dilaksanakan di Provinsi Riau. Kami berharap buku ini dapat menjadi pembelajaran dalam pencegahan bencana alam dan restorasi ekosistem bagi para peneliti, sektor swasta, masyarakat, LSM, pemerintah dan praktisi.

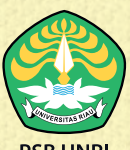

PSB UNRI

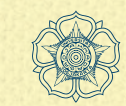

UNIVERSITAS GADJAH MADA

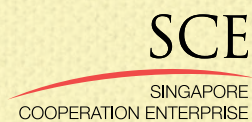

TEMASEK FOUNDATION

\section{cifor.org/CBFPR}

forestsnews.cifor.org

PROGRAM

PENELITIAN PADA

Hutan, Pohon dan

Wanatani
Penelitian ini dilaksanakan oleh CIFOR sebagai bagian dari Program Penelitian CGIAR tentang Hutan, Pohon, dan Wanatani (FTA). FTA adalah penelitian terbesar di dunia dalam program pembangunan guna meningkatkan peran hutan, pohon, dan wanatani dalam pembangunan berkelanjutan dan ketahanan pangan, serta untuk mengatasi perubahan iklim. CIFOR memimpin FTA dalam kemitraan dengan Bioversity International, CATIE, CIRAD, ICRAF, INBAR dan TBI.

Penelitian FTA didukung oleh Dana Perwalian CGIAR: cgiar.org/funders/ 